Historic, Archive Document

Do not assume content reflects current scientific knowledge, policies, or practices. 



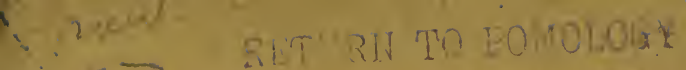

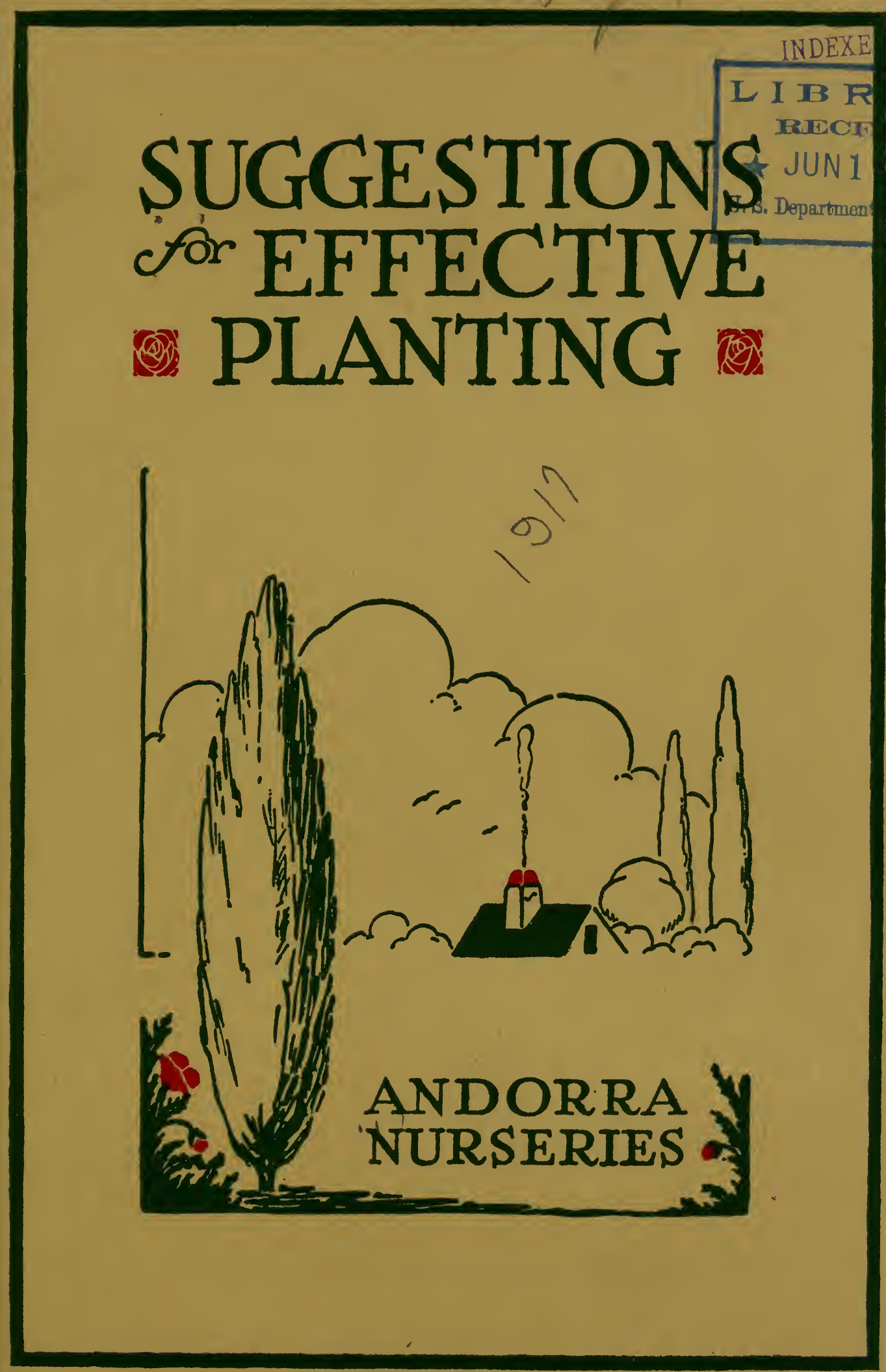





\section{SUGGESTIONS FOR EFFECTIVE PLANTING}

\section{JANUARY, 1917}

\section{CONTENTS}

Andorra

Suggestions for Effective Planting

Evergreens

Landscape Arrangement .

Care of Trees and Shrubs

Broad-Leaved Evergreens

Rhododendrons

Large Trees for Specimens or Screens

Deciduous Trees

Deciduous Conifers

Deciduous Shrubs .

Ground-Covers and Special-Purpose Shrubs

$$
\text { 61, } 62-96
$$

Roses

Reeds and Ornamental Grasses

99, г 00-г 38

Vines

Perennials

Ordering and Shipping Instructions .

Index of Common Names

Index of Botanical Names

$$
\text { I } 47^{-1} 50
$$

I 5 I

152

I 53

I $54-156$

I $57-160$

\section{ANDORRA NURSERIES \\ WM. WARNER HARPER, Proprietor \\ CHESTNUT HILL - PHILADELPHIA, PA.}




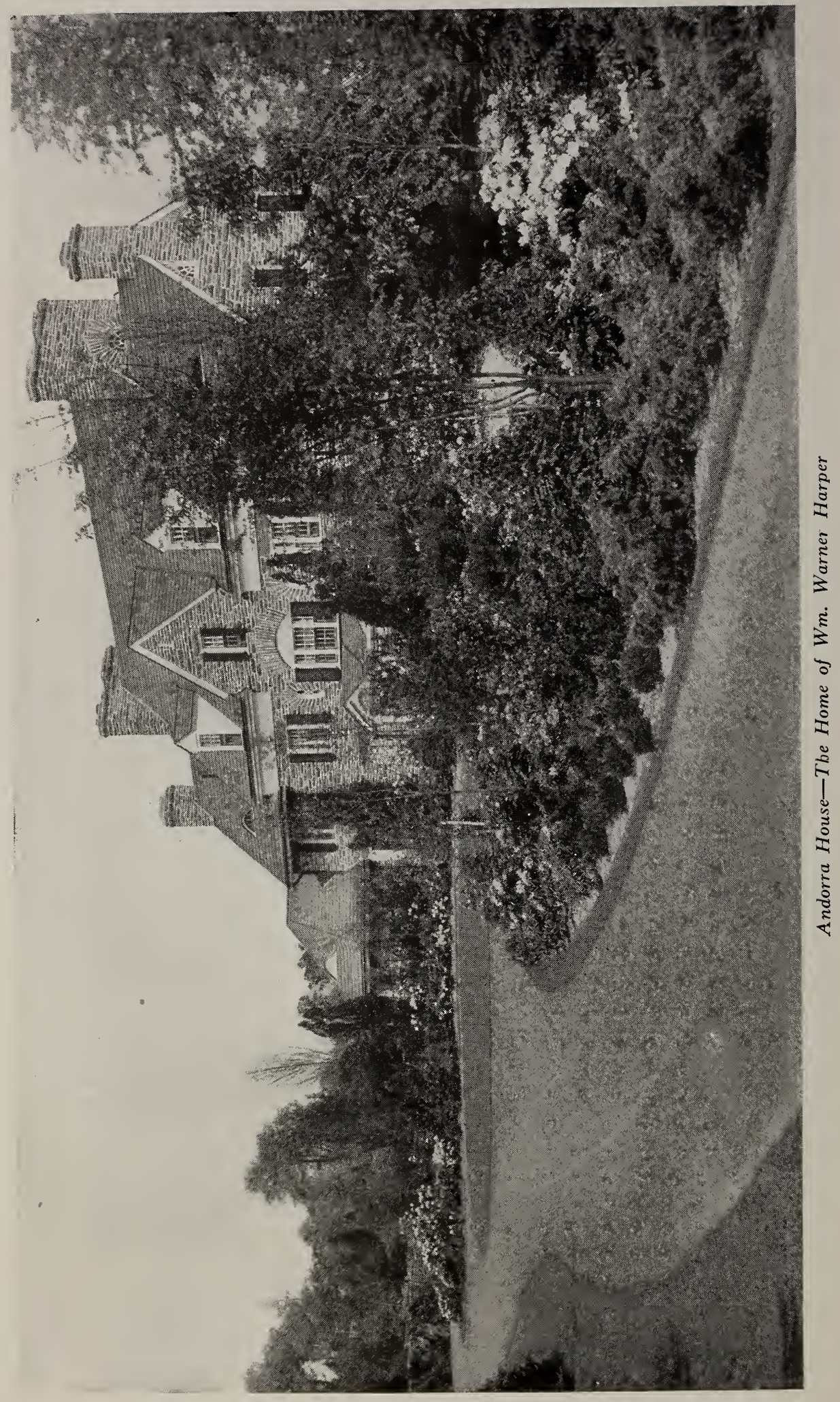



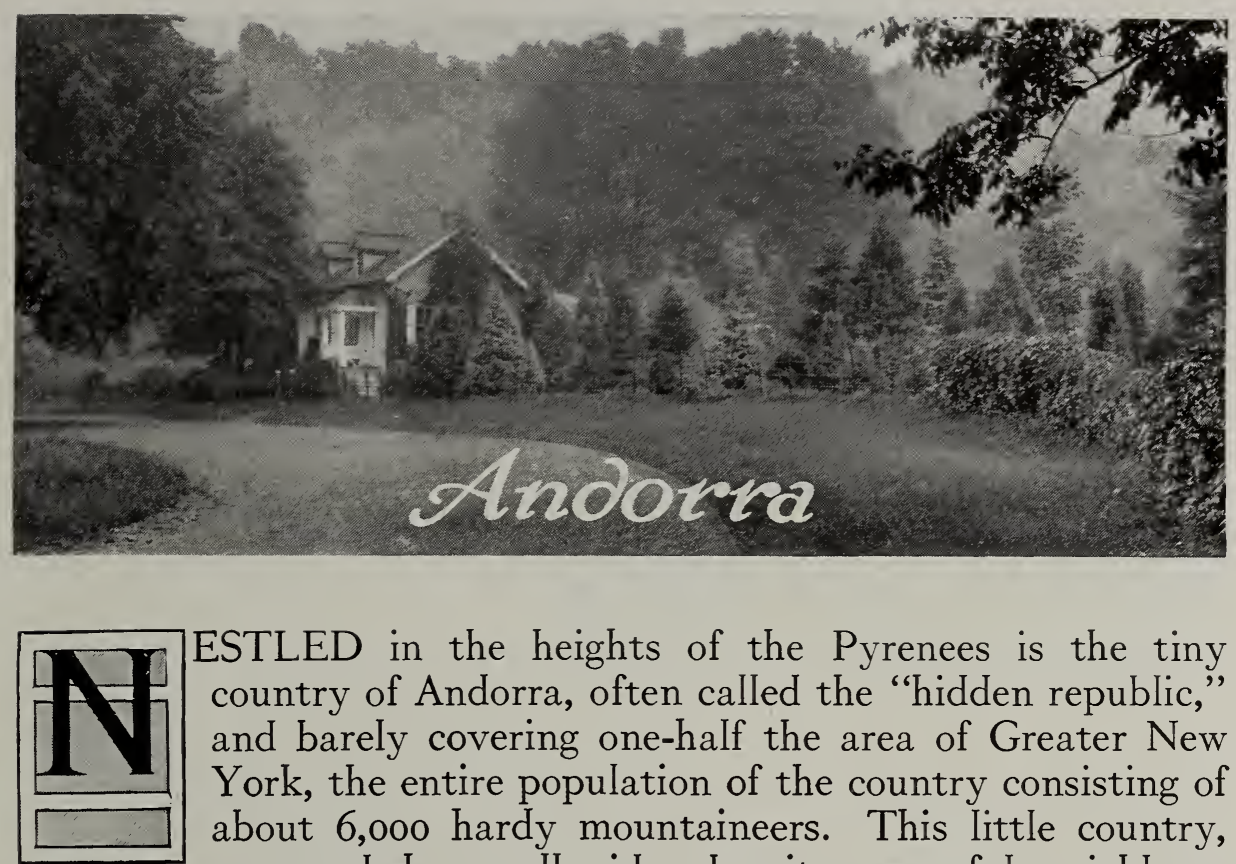

ESTLED in the heights of the Pyrenees is the tiny country of Andorra, often called the "hidden republic," and barely covering one-half the area of Greater New York, the entire population of the country consisting of about 6,000 hardy mountaineers. This little country, surrounded on all sides by its powerful neighbors, France and Spain, has, since 805 A. D., when it was established by Louis le Debonnaire, son of Charlemagne, maintained its independence and a national life of its own through the wonderful steadfastness of purpose and fearless integrity of its people, whose national head-dress even today is the red Phrygian cap of liberty.

Many are the charming legends of this little country of Andorra, and enchanting are the tales that are borne back to us by the few who have been fortunate enough to visit its sunny valleys, above which tower the peaks of the Pyrenees, on the lower slopes of which are great green pastures, and farther up the dark pine woods. Among the curious customs of the country is that, instead of a flag-pole and flag, they have the quaint custom of planting a tree in their public square, which they call a "tree of liberty."

A few miles outside of Philadelphia is the point where the Wissahickon Creek abandons its lazy meandering course through the sunny meadows of Whitemarsh and hurries into the swifter, shadowy waters of the rocky gorge through which it flows for six miles to the Falls of the

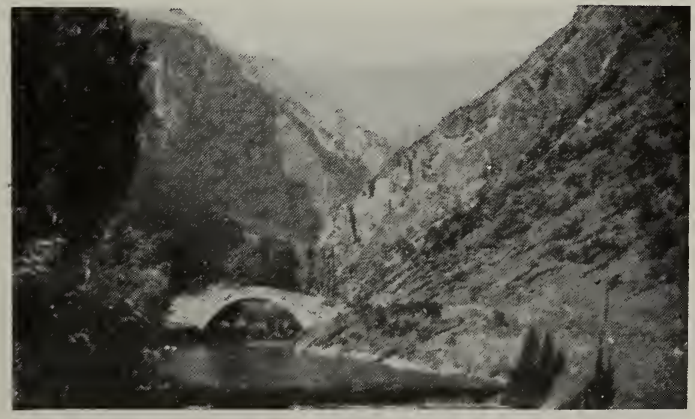

In Andorra, midway between the villages of Andorra and San Julian 
Schuylkill; here, over sixty years ago, Richard Wistar chose a high wooded hill as the site for a country home. The broad expanse of fertile meadows and the steep slopes of rocky hillsides, mounting

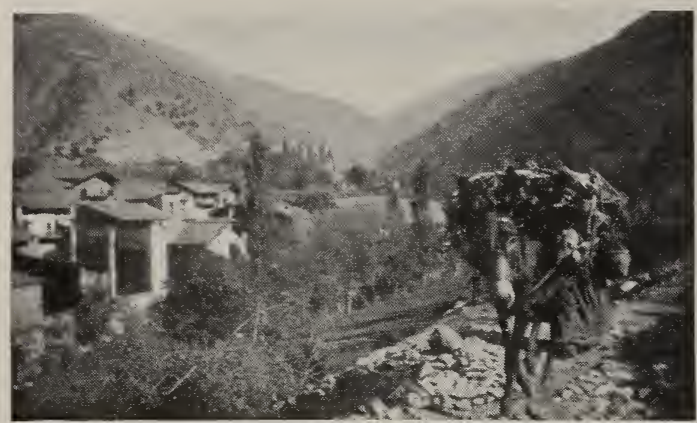

A glimpse of San Julian de Loria, Andorra to the hilltop overlooking the surrounding country for miles, gave a fancied resemblance to the sunny little country in the Pyrenees and so Mr. Wistar called the estate "Andorra."

Mr. Wistar was a lover of plants and a patron of horticulture, as were other members of this illustrious family, for we find Wistaria, one of the earliest plant introductions brought back from the Orient by far-sailing old sea-captains, was so named after Caspar Wistar, a professor at the University of Pennsylvania. Although Mr. Wistar never realized his dream of the house on the hill-top of Andorra, there are evidences of his weIl-laid plans on every hand in the many plants and trees which he planted before even starting on his house; and today the grove or park, planted with saplings sixty years ago, is shaded by stately magnolia trees, towering high to the tops of the old beeches and firs, and which in the spring are a riot of waxy white flowers.

Occupying the lands once owned by Mr. Wistar, the Andorra Nurseries were started some thirty years ago and, from a modest

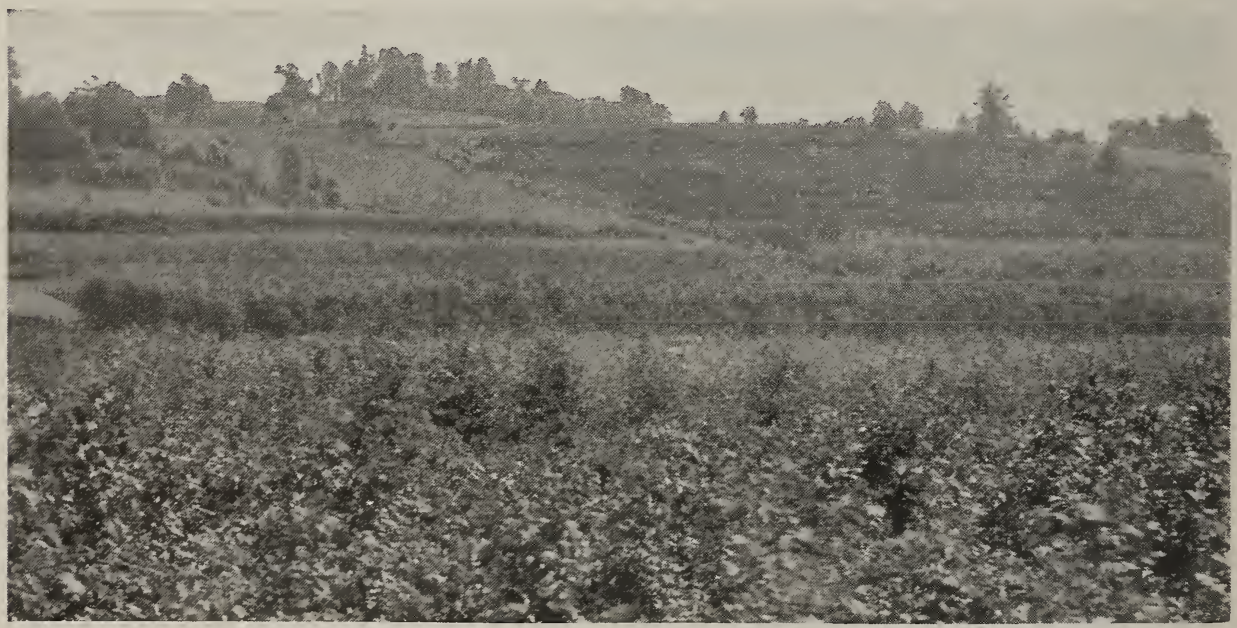

The broad sunny slopes of the Andorra Nurseries 
beginning, have grown year by year until at the present time there are included in their boundaries over a thousand acres, comprising lands of great diversity of soil and exposure. By a careful study of the requirements for the ideal growth and development of the countless plants, natives of every part of the world, we find them growing in the Nurseries in light or heavy soil, with exposure to the warm sun or cold north winds as the nature of the plant may deniand so as to fit it best for transplanting to other localities, north or south of this latitude, or where conditions of soil or exposure are not ideal.

As the little country of Andorra holds the distinction of being the smallest republic in the world, so the Andorra Nurseries are distinctive, in that from the beginning they have maintained a higher standard of excellence in their nursery stock than others, and at the present time are the largest nurseries in the country growing exclusively ornamental nursery stock.

The Andorra Nurseries are situated at Chestnut Hill, Philadelphia, the office being at the entrance of the renowned Wissahickon Drive, a short distance west of the Reading Pike (Germantown Road) on the City Line. Chestnut Hill is a suburb of Philadelphia, reached by frequent train-service on two lines from the city - the Pennsylvania Railroad from Broad Street Station, and the Philadelphia \& Reading from the Reading Terminal. At all seasons of the year those who are interested in plants or landscape beauty will enjoy a visit to Andorra as much as will we, whose pleasure it is to show them about.

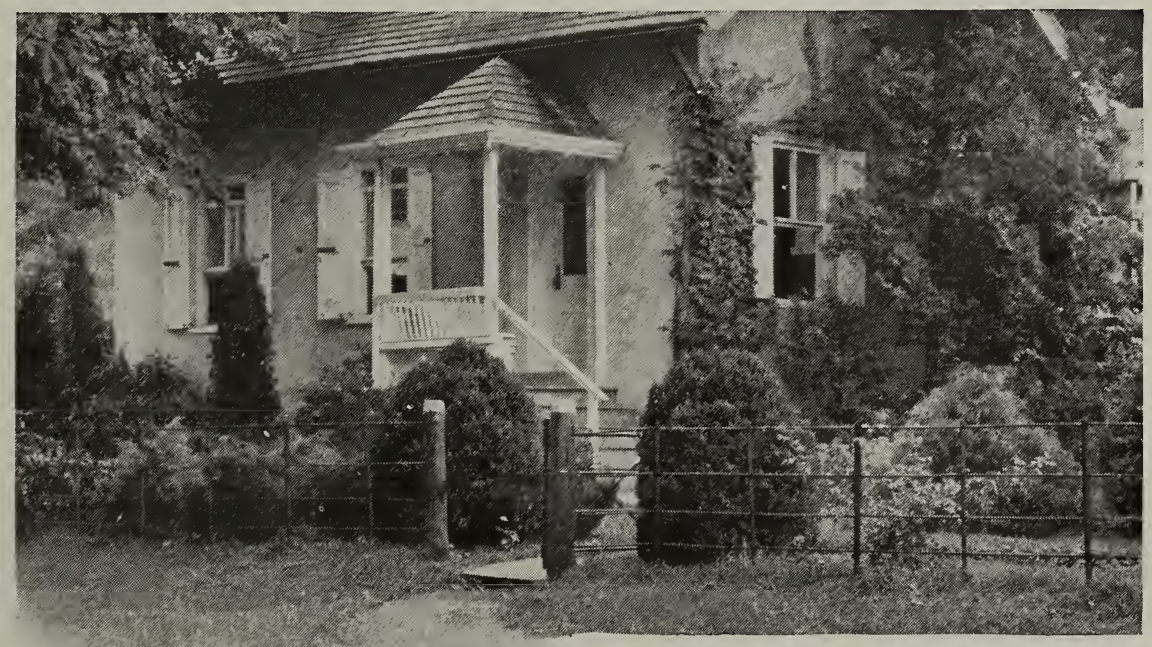

The Office, Andorra Nurseries 


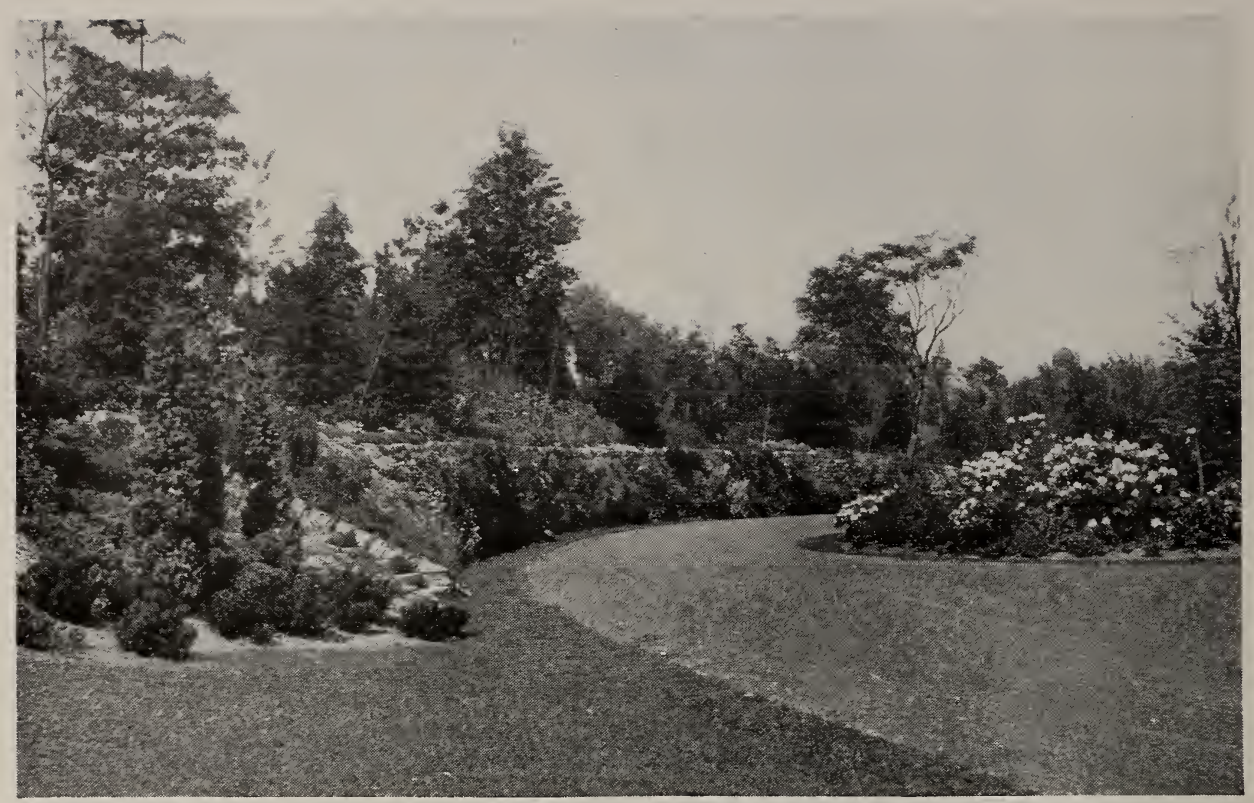

\section{Suggestions for Effective Planting}

$\mathrm{T}$ this booklet we present an original idea in the arrangement of a nursery catalog, in line with our policy of service and attention to the needs of our patrons in every detail of the business. We have discarded the alphabetical or botanical classifications which to many are sometimes merely a maze of strange Latin names and botanical terms and have endeavored to list our plants in a concise, convenient manner, with regard to their uses in garden and landscape planting. Of course, many trees and plants are adapted to a wide variety of situations, which readily suggest themselves on closer acquaintance, but in the main the classifications in the following pages convey the suggestion of the various landscape arrangements to which the trees and plants most readily lend themselves and to which they are preëminently fitted by their natural habit of growth.

A mere statement of height is a poor criterion in judging the quality or value of nursery stock, as the factors which make for successful growth and satisfactory results are a strong, vigorous root-system and thick spreading top. All our nursery stock is grown with ample width for such development and we transplant frequently to produce a strong fibrous root-system, so that the buyer is assured a stocky well-balanced plant, whether large or small. Mere height may be only an indication of crowding and lack of proper transplanting in the nursery. 


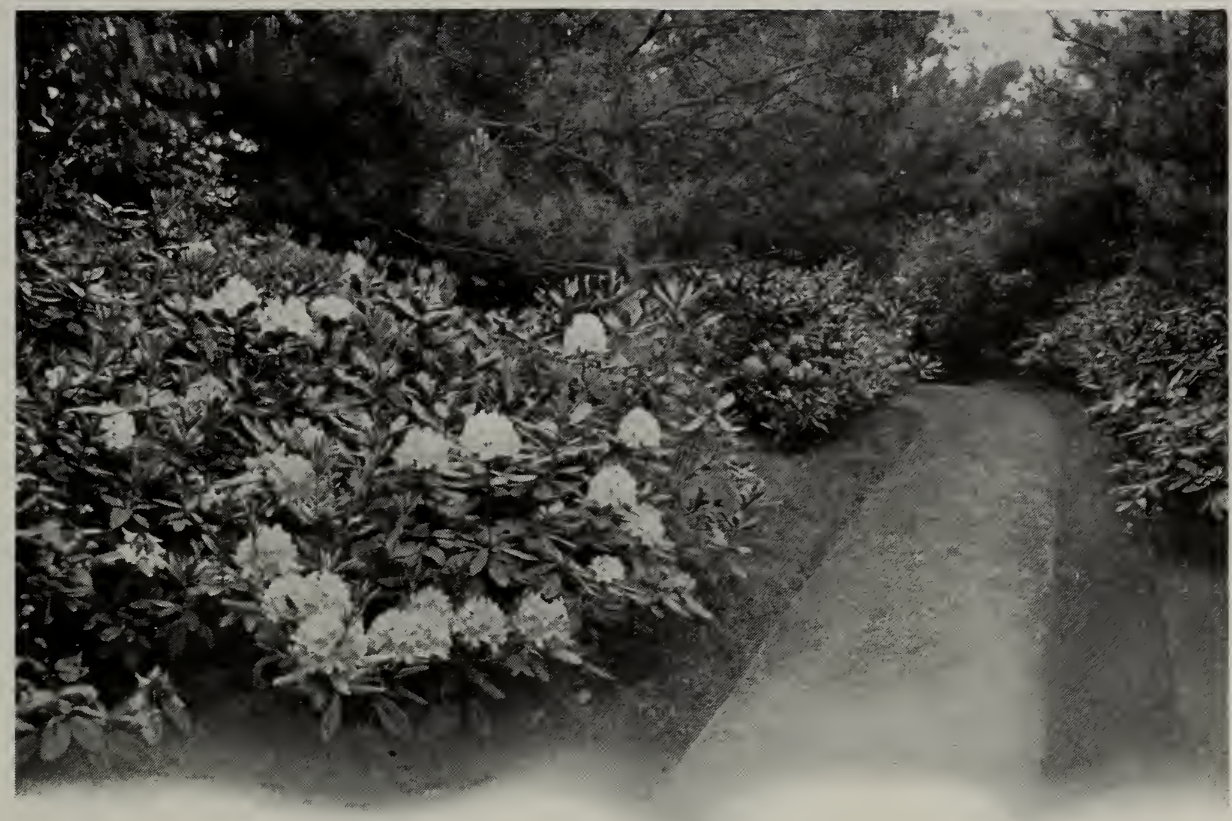

\section{Evergreens}

7 MANY the term "Evergreens" and the question of just what plants are included in it is a matter of some uncertainty. In a way, of course, the word is self-explanatory, meaning a plant which, unlike deciduous plants, does not lose its leaves in winter, but is in fact ever-green, and so includes the Pines, Cedars, Yews, and most other conebearing plants (Conifers). It also includes what are commonly called "Broad-leaved" Evergreens, like the Rhododendrons, Hollies, Boxwood, and Indian Azaleas. In a general way, it may be said that the Conifers are most valuable for their form and variety of coloring, while the Broadleaved Evergreens possess the added merit, in most cases, of a profusion of gorgeous flowers in spring.

Until within a comparatively few years, the value of all Evergreens for their warmth of color and interest in the winter landscape was largely unappreciated; today the dictates of good taste encourage the use of Evergreens of all sorts as being the most desirable plants in the immediate environment of the house, for they are pleasant to live with the year round, especially when used in combination with bright-flowered Deciduous Shrubs, as for instance, the Ghent Azaleas, or bright-berried shrubs like the Japanese Winter Berry. In informal work, in mixed border plantations, and especially about the base of the house, pleasing effects can always be obtained with appropriate combinations of any of the various species and varieties, one sort acting as a pleasing foil to others.

The cheapest Evergreens one can buy are those which have been freshly imported from Holland where, owing to the mild, even climate, and on 
account of an inexhaustible supply of water about eighteen inches below the surface of the soil the plants are practically "forced." Until these plants have become acclimated by growth in this country for severaI years, and have had a chance to produce fresh roots in addition to the soft roots formed in the Dutch black peat, they suffer severely from drought and winter-killing and many die a lingering death frve years after planting. This is especially true of Rhododendrons and Boxwood.

The plants which we offer have been growing for several years in our nurseries, and the purchaser is not exposed to the risk attendant upon the purchase of foreign stock.

The following arrangement is the one by which we have grouped our stock of many species of Evergreens.

Evergreen Trees for Landscape Groups, Screens, or Windbreaks, page 9.

Evergreen Trees for Specimens, page 13.

Evergreens for Formal Effects: Conifers, page 17.

Boxwood, page 29.

Evergreens for Informal Plantings: Conifers, page 33.

Trees of Medium Height, page 34.

Low-growing and Spreading Plants, page 38.

Flowering Broad-leaved Evergreens, page 41.

Hybrid Rhododendrons, page 42.

Azaleas and Other Beautiful Flowering Evergreens, page 49.

Broad-leaved Evergreens Valuable for Berries, Form, and Foliage, page 55.

Evergreens for Ground-Covers, page 59.

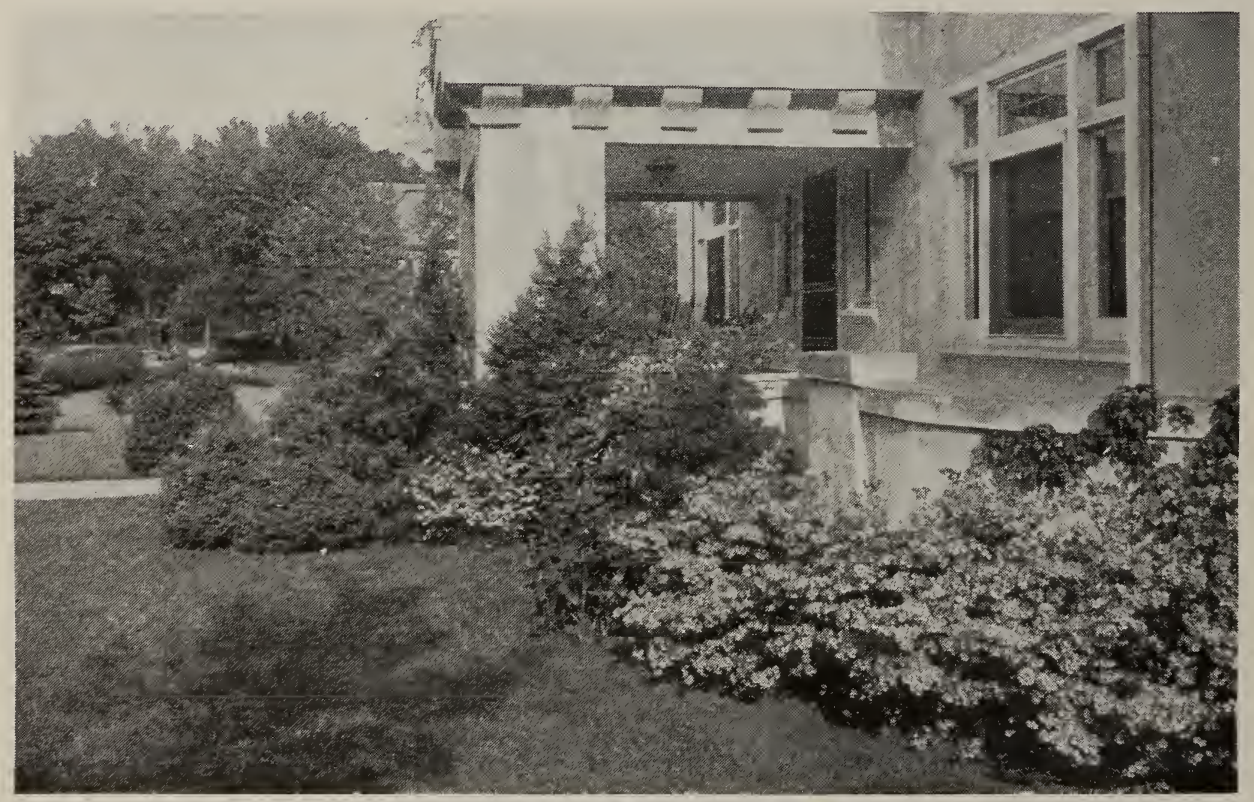

An effective planting of Evergreens 


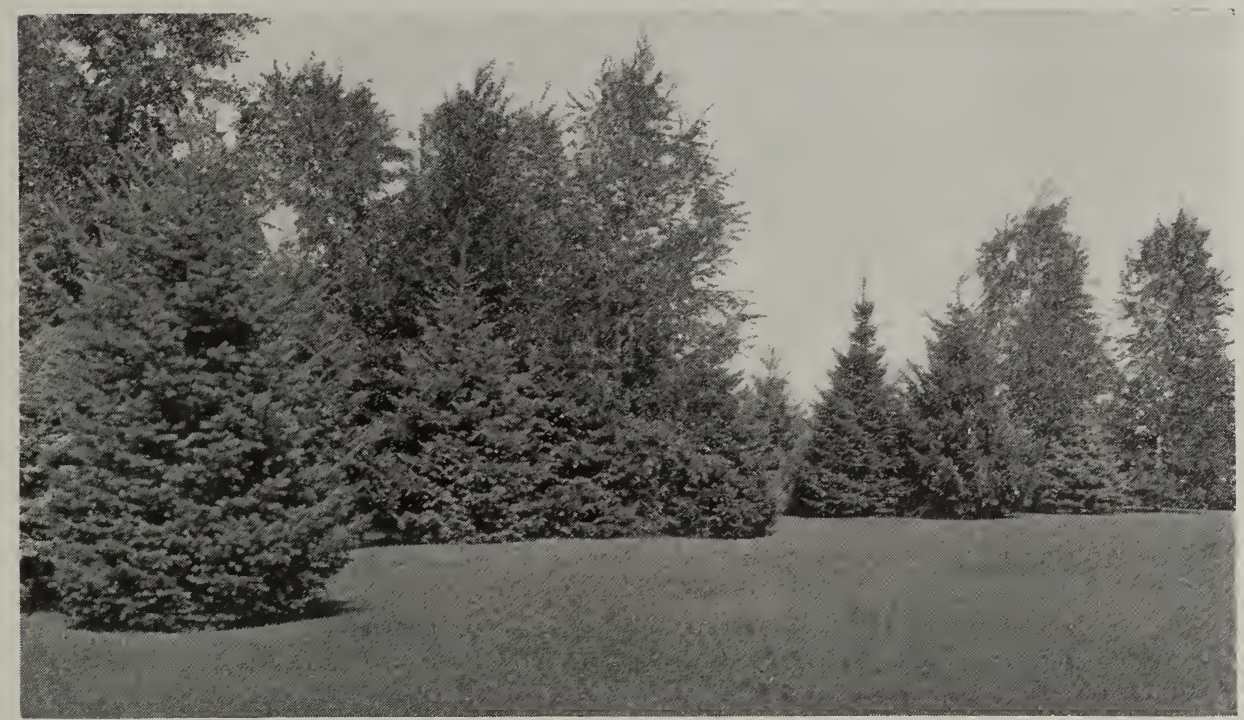

An effective belt planting of tall-growing Evergreens combined with Deciduous Trees to form a good windbreak

\section{Evergreen Trees for Landscape Groups, Screens, or Windbreaks}

TN the climate of the eastern United States, characterized as it is by spells of zero weather in winter and droughts in summer, we can never hope to equal the Cedars of Lebanon brought back by the returning Crusaders, or the Redwood trees which, in the soft, mild climate of the British Isles, grow so Iuxuriantly; but luckily we are endowed with other trees more valuable to us and more in keeping with our natural landscapes, some of which are natives of our own country and some are introductions from Japan and China.

The sturdy White Pine in the open, the graceful Hemlock of more shade-enduring habits, together with the quicker-growing Austrian and Scotch Pines and the Spruces, are the trees best suited for effective landscape massing, or for purposes of protection from unpleasant winds or sights. Again, they are very useful as high borders back of the smallergrowing 'Evergreens, especially in combination with flowering trees. The pleasing variety in form and coloring of these trees produces beautiful effects when they are planted in groups, and many are desirable for specimens.

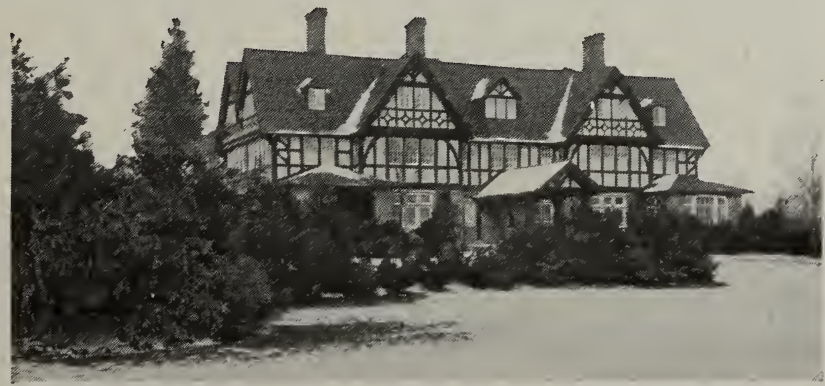

Planting of Evergreens completely screening the service end of the bouse 


\section{White Spruce}

Picea alba

Dense, compact, tall-growing; light bluish green needles; an excellent tree for the colder parts of the country.

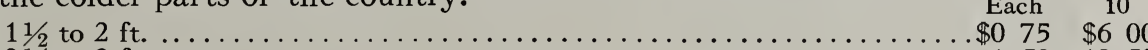

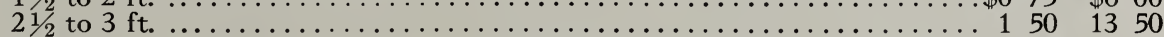

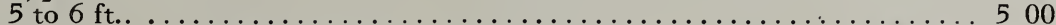

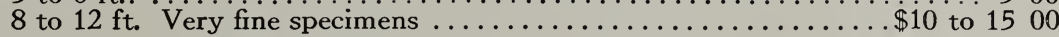

\section{Norway Spruce}

Picea excelsa

Forms a taIl, conical-shaped tree with rather gracefuI, somewhat drooping branches when mature. May be planted closely as a hedge and kept clipped, and is also a good forest tree.

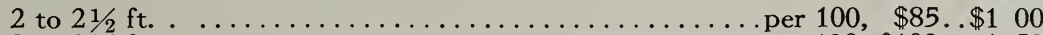

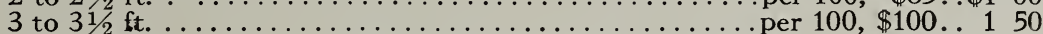

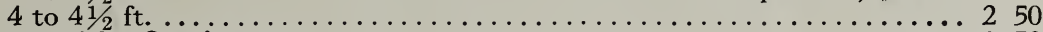

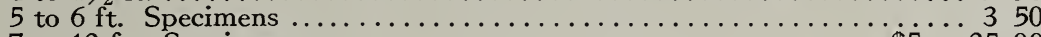

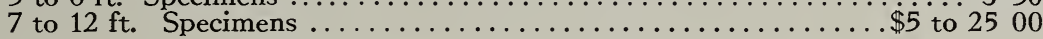

10

$\$ 900$

1350

2350

3250

\section{Colorado Spruce}

Picea pungens

Compact-growing tree with pleasing glaucous green needles. The richly colored varieties of Blue Spruce are listed under "Evergreen Trees for Specimens;" when planted in groups among other trees, they are especially attractive for adding a nice touch of color.

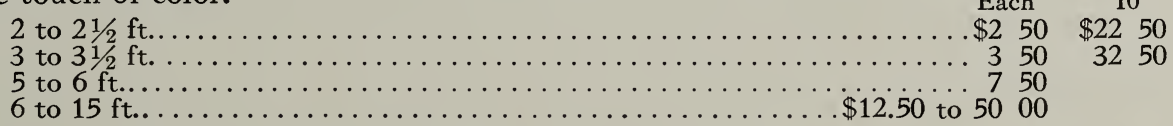

\section{Douglas Fir}

\section{Pseudotsuga douglasii}

\section{Hemlock} shade.

This is the giant forest tree of the Pacific Northwest. Our stock is from the Colorado form, no other being hardy in the East.

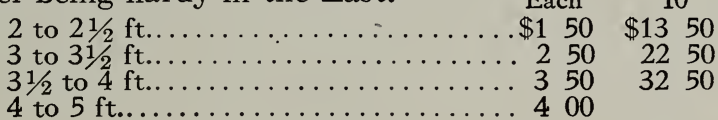

Tsuga canadensis

This tree possesses remarkable adaptability to a variety of situations, as a graceful specimen, in masses interspersed with Flowering Dogwood or Crab-apples, with other Evergreens or, again, planted closely together and clipped, it forms one of the best and most compact Evergreen hedges. Particularly valuable for its ready growth in dense

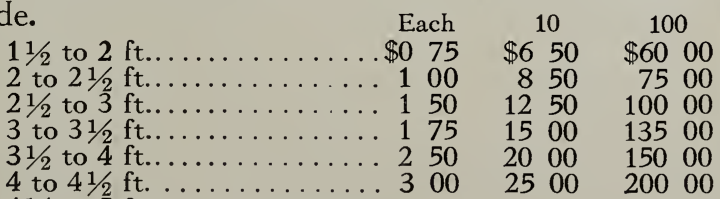

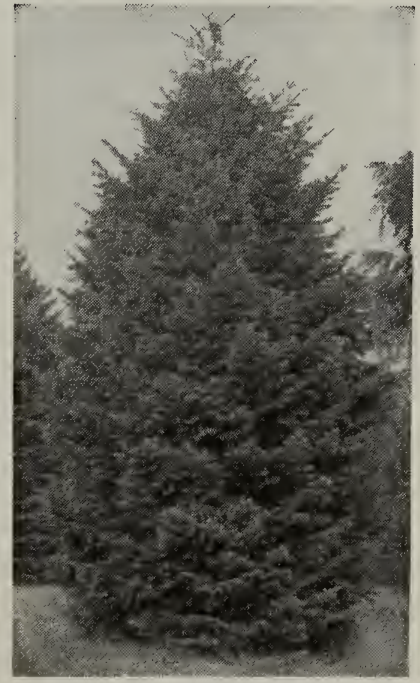

Stately specimen of Douglas Fir

Each $\quad 10 \quad 100$

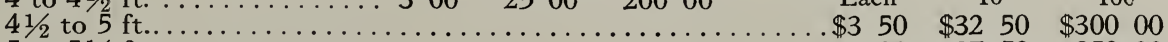

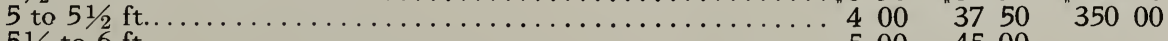

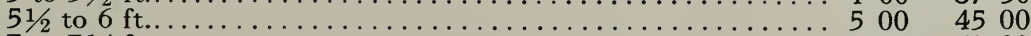

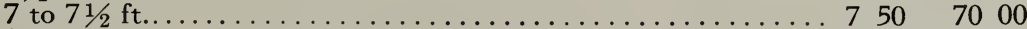

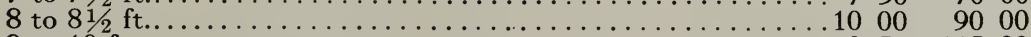

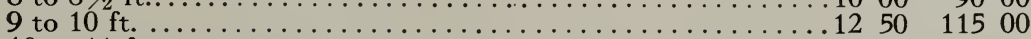

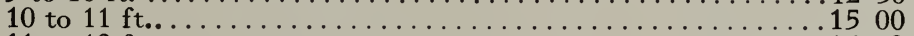

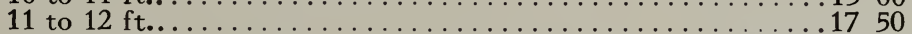

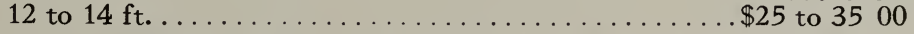




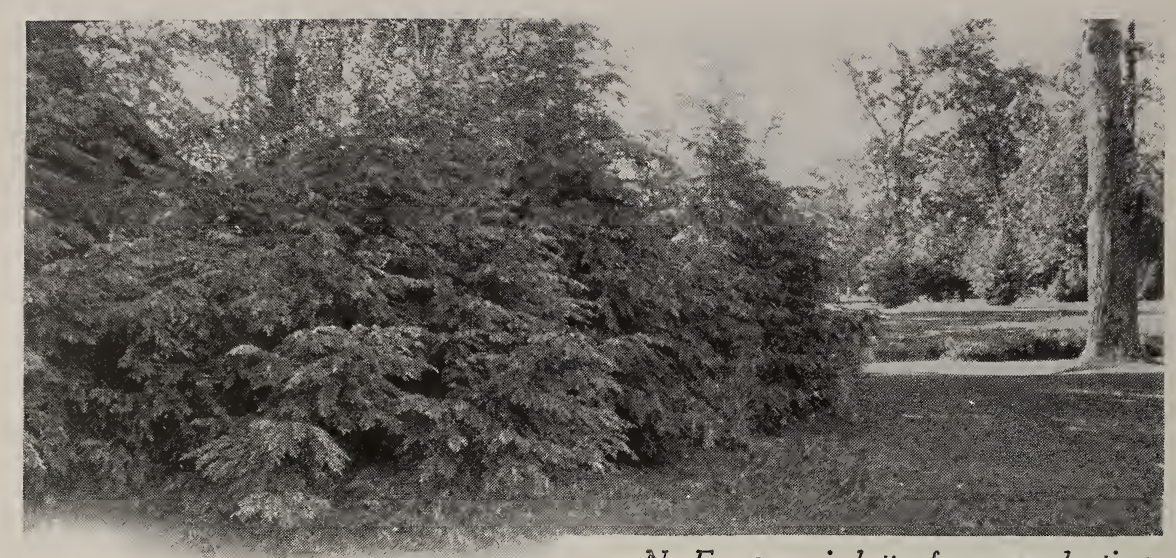

No Evergreen is better for mass planting than the Hemlock, with its graceful babit and featbery foliage.

\section{Landscape Arrangement}

7 HE conditions which make for most rapid and successful plantgrowth are those found in a climate of uniform or fairly equable temperature and abundant rainfall. The luxuriant plant-growth of the tropics is an outcome of these conditions in a region of uniformly high temperature. In the North Temperate Zone we have the examples of nature's prodigality on the northwest Pacific Coast of our own country and in the British Isles and Japan, all tempered by winds from warm ocean currents. In these countries all the plants native to temperate regions and some sub-tropical plants flourish with a minimum of care and attention. In our own country we are confronted in most places with conditions exactly the opposite of those favorable to the natural growth of a wide range of plants, either by extremes of heat and cold or moisture and drought.

But, after all, it is only a matter of establishing reasonable artificial conditions that enable us to draw from the wealth of plant-life of more favored regions and harmoniously combine their richness with our native plants of more severe and somber habit. Let us consider that all trees and plants thrive best in large groups and masses in much the same manner as every other form of life, including man, each individual combining with the others to provide protection and assistance of some sort to all others in the community, whether it be a forest of trees, a thicket of shrubs, or a thriving city of man. With this thought in mind let us logically arrange our plantings so that the coarser native trees and shrubs in large masses may form the groundwork of our composition, as it were, blending harmoniously with the landscape, and most important of all, giving the needed protection to the more choice species of Evergreen trees and shrubs which will brighten our gardens and the planting about our homes during the seasons of the year when native plants serve but as an attractive background and foil for the richer and more dignified beauty of the Evergreens. 


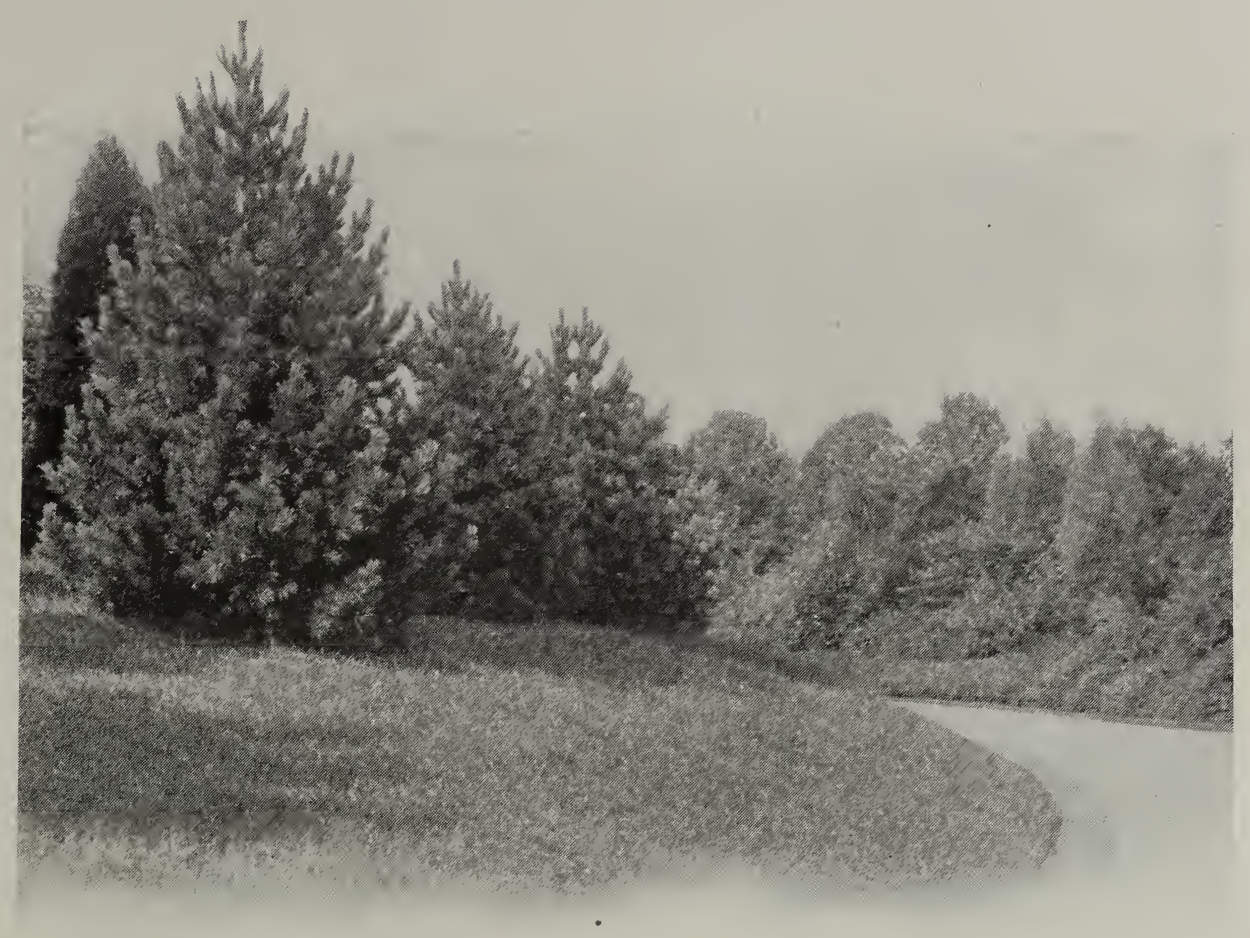

\section{Evergreen Trees for $S_{\text {pecimens }}$}

$\mathrm{E}$

VERGREENS planted singly or in groups as specimens are pleasing in appearance at all seasons of the year and, on account of the variety of coloring and form from which we may choose, there is always some species adaptable to any particular situation where such trees would be appropriate.

These trees are also desirable in Evergreen boundary plantings for the variety of coloring given by their foliage; and, again, many Evergreens listed elsewhere form equally good specimen trees, depending upon the size and form desired.

\section{Silver Cork Fir}

Abies arizonica

The bark is cream-colored and of a corky texture.

4 to $5 \mathrm{ft} . . \ldots \ldots \ldots \ldots \ldots \$ 50$ to $\$ 1000$

\section{White Fir}

Abies concolor

Rapid-growing; a majestic tree when mature, having rich silvery needles. One of the finest and hardiest of the Firs, standing well in the most exposed positions.

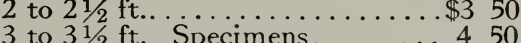

4 to $4 \frac{1}{2} \mathrm{ft}$. Specimens......... 600

$41 / 2$ to $5 \mathrm{ft}$. Specimens......... 750

$51 / 2$ to $10 \mathrm{ft}$..........\$10 to 3500

10

$\$ 3250$

4250

5000

6000

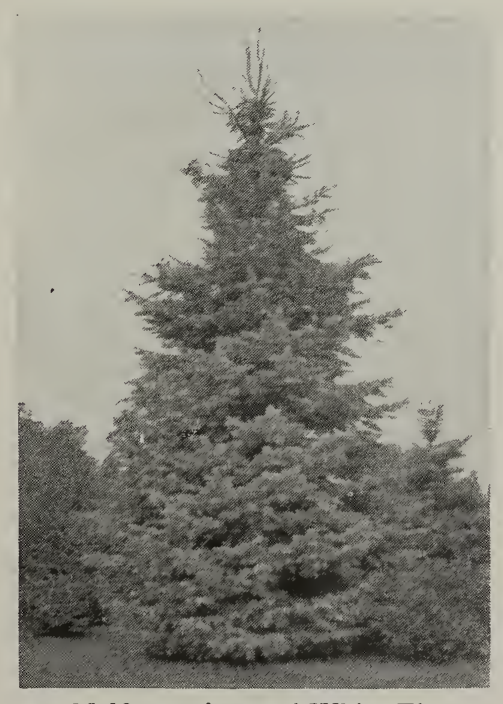

Noble specimen of White Fir 
The rich, dark, glossy green effect of this compact, slow-growing, conical tree is especially attractive.

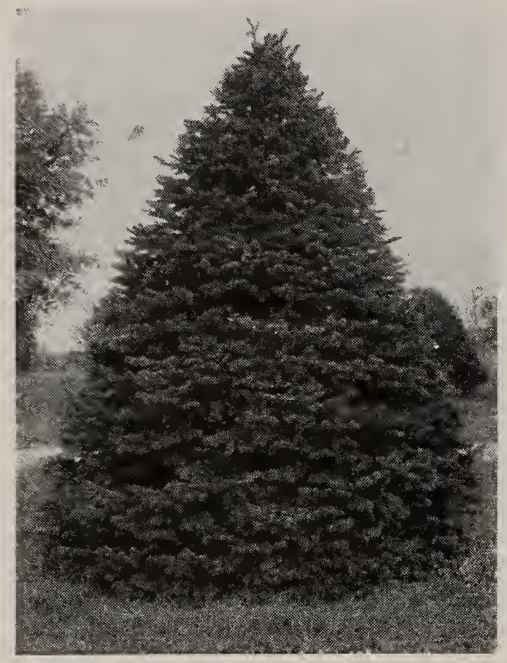

This illustrates the dense compact babit of Nordmann's Fir

\section{Alcock's Spruce}

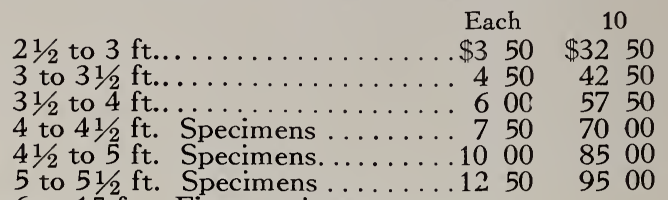

5 to $51 / 2 \mathrm{ft}$. Specimens .........12 50

6 to $15 \mathrm{ft}$. Fine specimens. $\$ 15$ to 10000

\section{Mt. Atlas Silver Cedar}

Cedrus atlantica, var. glauca

This tree approximates in appearance, when grown, the Cedar of Lebanon which is not commonly hardy here. It has strikingly handsome, almost silver-white needles. The general appearance of this tree is quite distinct in its rather rugged branch formation.

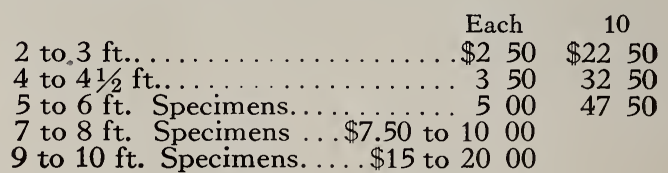

Picea alcockiana

A rapid-growing tree from the mountains of Japan.

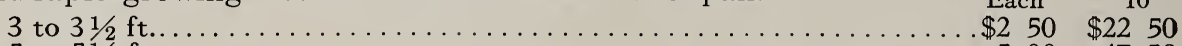

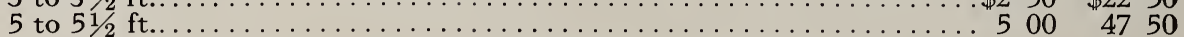

\section{Oriental Spruce}

Picea orientalis

Compact in habit with very short, dark green needles. Repays extra care in

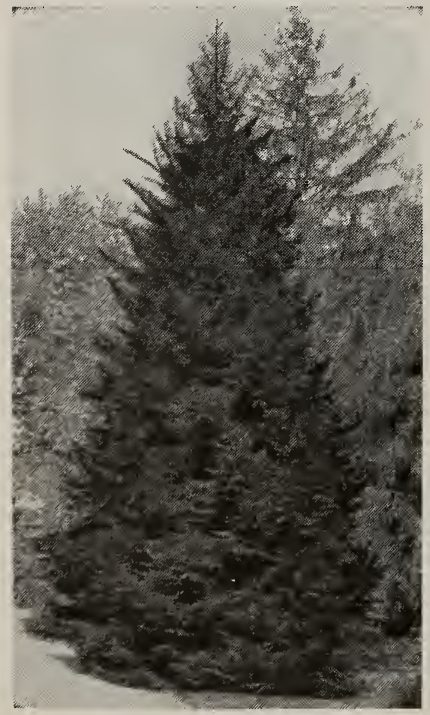

Oriental Spruce transplanting.

Each 10

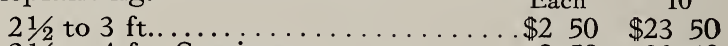

$31 / 2$ to $4 \mathrm{ft}$. Specimens.......... $350 \quad 3250$

$4 \frac{1}{2}$ to $5 \mathrm{ft}$. Specimens.......... 500

6 to $14 \mathrm{ft}$. Specimens.......\$10 to 5000

\section{Golden Norway Spruce}

Picea excelsa, var. aurea

The young needles are very showy, tipped with golden yellow.

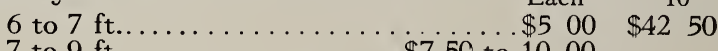

7 to $9 \mathrm{ft} \ldots \ldots \ldots \ldots \ldots \ldots \ldots 7.50$ to 1000

Tiger's Tail Spruce

Picea polita

Forms a broadly conical-shaped, medium-sized tree. A Japanese introduction of attractive character. The warm green coloring of this tree often lends a needed touch of brightness among more somber trees.

Each $\quad 10$

4 to $5 \mathrm{ft} \ldots \ldots \ldots \ldots \ldots \ldots \ldots \ldots \ldots \ldots \ldots \ldots$

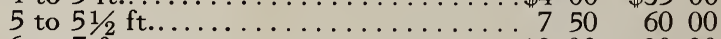

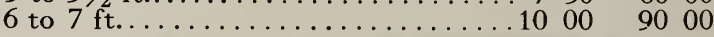


Colorado Blue Spruce

Picea pungens, var. glauca

The silvery blue of this symmetrical tree forms an attractive note of soft color desirable when planted as a specimen or in groups. The trees propagated by grafting exhibit the best foliage and richest coloring. AIl of the following are carefully selected for their soft, silvery blue coloring.

\begin{tabular}{|c|c|c|}
\hline $\begin{array}{l}21 / 2 \mathrm{ft} . \\
\text { to } 3 \mathrm{ft} .\end{array}$ & \begin{aligned} \multicolumn{2}{c}{ Each } \\
.$\$ 250 \\
.350 \\
.4400 \\
500 \\
5\end{aligned}$ & $\begin{array}{rl} & 10 \\
\$ 22 & 50 \\
32 & 50 \\
37 & 50 \\
47 & 50\end{array}$ \\
\hline
\end{tabular}

\section{Koster's Blue Spruce (Grafted)} Picea pungens, var. Kosteriana

\begin{tabular}{|c|c|}
\hline $\begin{array}{l}22 \text { to } 2 \mathrm{ft} \text {.. } \\
\text { to } 21 / 2 \mathrm{ft} \text { to } 3 \mathrm{ft} \text {. } \\
\text { to } 31 / 2 \mathrm{ft} \text {. } \\
1 / 2 \text { to } 4 \mathrm{ft} \text {. } \\
\text { to } 411 / 2 \mathrm{ft} \text {. }\end{array}$ & 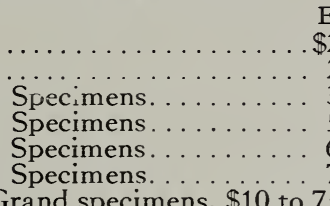 \\
\hline
\end{tabular}

\section{Spanish Fir}

\section{Picea pinsapo}

Gray-green needles; a most interesting tree, hardy only as far north as Philadelphia.

8 to $10 \mathrm{ft}$

Each $\$ 2500$

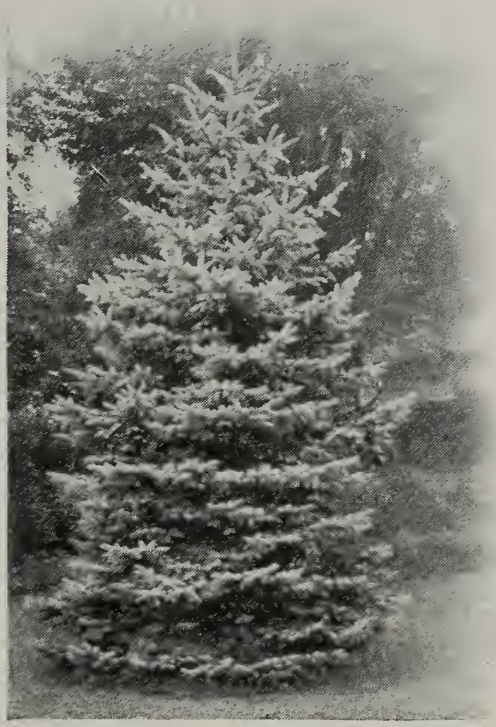

The Colorado Blue Spruce

Blue Douglas Fir

Pseudotsuga douglasii, var. elegans glauca

Considered hardier than the Douglas Fir and is of slower growth; needles silvery green.

\begin{tabular}{|c|c|}
\hline $\mathrm{Eac}$ & \\
\hline $\begin{array}{r}\$ 400 \\
.500\end{array}$ & $\begin{array}{rl}\$ 38 & 50 \\
45 & 00\end{array}$ \\
\hline
\end{tabular}

$31 / 2$ to $4 \mathrm{ft} \ldots \ldots \ldots \ldots \ldots \ldots \ldots \ldots \ldots \ldots \ldots \ldots \ldots \ldots \ldots \ldots \ldots \ldots \ldots$
4 to $41 / 2 \mathrm{ft} \ldots \ldots$

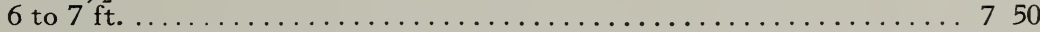

\section{Swiss Stone Pine}

\section{Pinus cembra}

Resembles, in a way, the White Pine, but the needles are shorter and it is of slower, more compact growth and, on account of this, is also valuable for formal work. These pines are shown effectively planted, in the illustration at the top of page 13.

\begin{tabular}{|c|c|}
\hline $\begin{array}{l}\text { age } 13 . \\
2 \text { to } 21 / 2 \mathrm{ft} \text {. } \\
21 / 2 \text { to } 3 \mathrm{ft} \text {. } \\
3 \text { to } 31 / 2 \mathrm{ft} \text {. } \\
31 / 2 \text { to } 4 \mathrm{ft} \text {. } \\
4 \text { to } 41 / 2 \mathrm{ft} \text {. }\end{array}$ & $\begin{array}{r}\text { Each, } \\
\$ 300 \\
3350 \\
4400 \\
5500 \\
6 \\
600\end{array}$ \\
\hline
\end{tabular}

Bhotan Pine

Pinus excelsa

Its Iong, silvery gray-green needles and wide, sweeping, graceful branches commend this as a beautiful specimen tree.

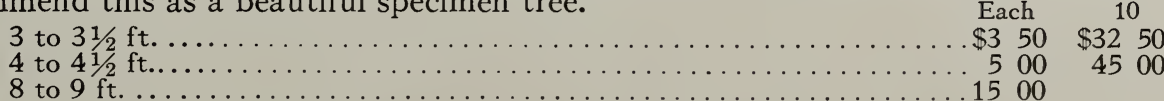

Of relatively slow growth, forming a dense pyramid of medium height, valuable where taller Pines are not in keeping; gray-green needles.

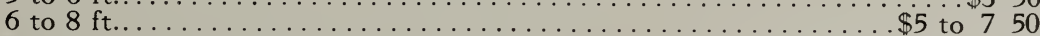


Much richer in appearance than the common Hemlock, being of more compact habit; the cones are larger - an inch or more in length.

$11 / 2$ to $2 \mathrm{ft} . . . .$.

Combines all the attractions of the graceful growth of the native Hemlock with the added charm of its more decorative needles and cones. It is still a rare tree in this country and few are acquainted with its beauty.

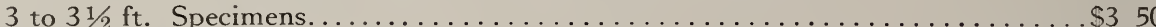

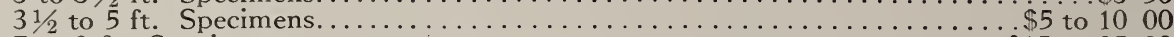

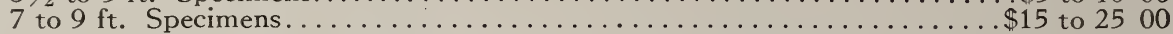

\section{The Care of Trees and Shrubs after Planting}

7 HIS is especially important for the first few years until they shall have become thoroughly established in their new location. It is really a very simple matter, if thought be given to a few points as to what is essential to provide for the most successful results in planting.

In the first place, a tree or shrub in its younger stages naturally makes its roots near the surface of the ground, and for a time after it is planted every effort should be made to continue the growth of these surface roots until it shall have put forth its deeper, permanent feeding-roots, which will search the lower strata of soil for food and moisture. This can be most successfully done by applying a thick mulch of manure 3 to 4 inches deep to the ground, after planting, which will keep the surface soil loose and moist and at an even temperature, not alternately hot in the baking sun of mid-day in summer and quickly frozen in early winter. This mulch also permits the free passage of air and falling moisture into the soil.

In case the appearance of a mulch is undesirable, the planting should be so arranged that low-growing varieties may be planted close together at the front of a group or border to screen the ground in the interior of the bed. Or again, the same ends are accomplished if a sufficient dust-mulch is provided by constant cultivation.

During periods of drought, new plantings, especially of Evergreens, should be thoroughly watered so that the soil is kept constantly moist.

If Evergreens are not protected by the planting of thick masses of deciduous trees and shrubs which would form a windbreak, artificial barriers, as of Evergreen boughs, should be erected in places which will prevent a direct draft from the prevailing inclement wind from blowing through the plants. Most Evergreens are "winter killed," not so much from actual cold as from the fact that the soil around them is not thoroughly and completely mulched to prevent early freezing and thereby enabling them to absorb moisture until late in the winter, and from their exposure to the drying winds through lack of proper protection. Always remember that thrifty plants, well manured and properly attended to in spring and fall, are less exposed to attacks of insect enemies or fungous diseases than plants which are ill-tended and uncultivated. See page 70. 


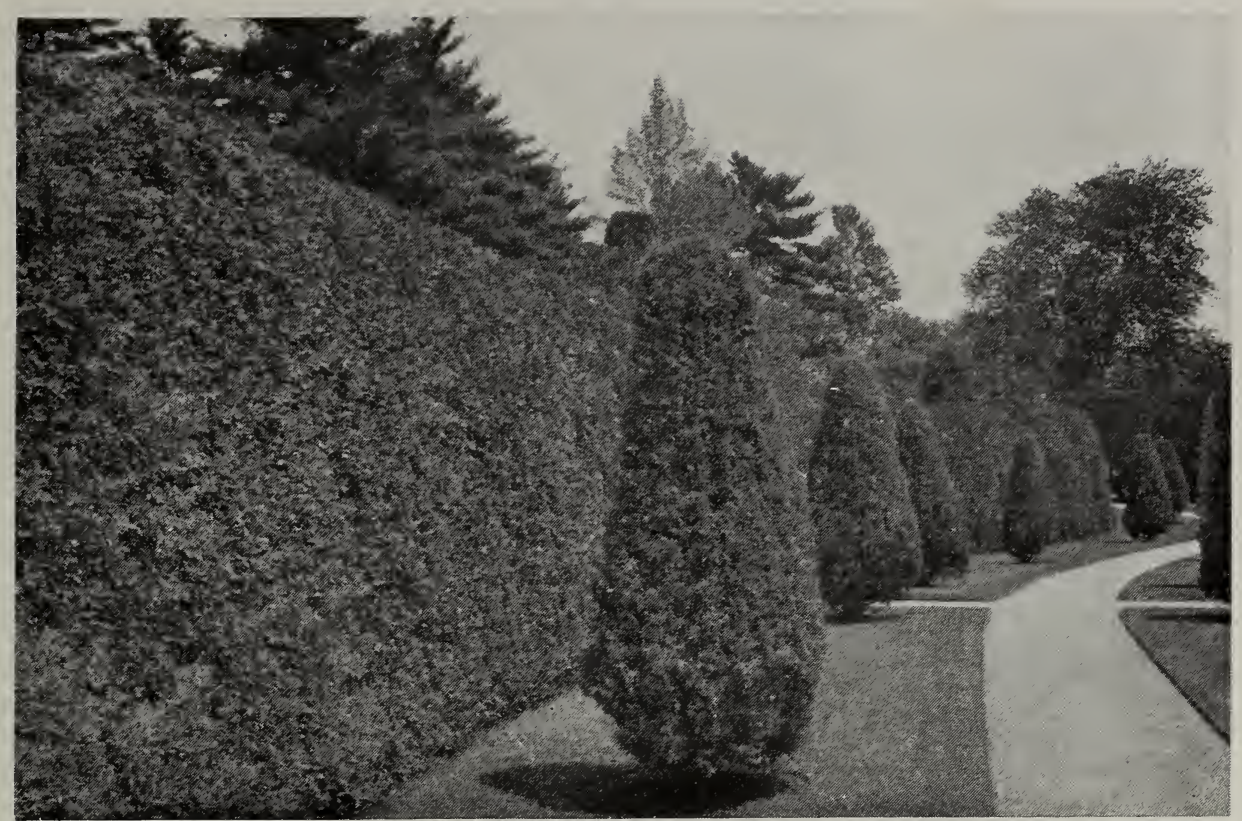

Pyramidal Arborvitæs

\section{Evergreens for Formal Effects - Conifers}

T

HE quiet dignity and self-restraint in treatment characteristic of the English formal garden, where dependence is placed more on the actual plants with subdued architectural details for the spirit of the design, or the more classic design of Italian gardens, in which the use of plants is more for their value as notes of form or color in architectural composition, can be attained in American gardens by a great variety of trees and low Evergreens which are listed below. We have elsewhere referred to the use of the Norway Spruce and Hemlock for high, clipped hedges and many of the more compact-growing trees, to be found in the category of "Evergreen Trees for Specimens" (see page 13), are applicable for formal effects also. The plants catalogued below either naturally possess a close formal habit of growth or are adaptable to clipping into a desired form. Most of these Evergreens when planted in informal groups and borders or about the base of a house, especially when used in combination with other conifers or broad-leaved Evergreens of a more informal habit of growth, seem to lose the appearance of stiffness presented when planted formally and serve pleasantly to relieve what might otherwise be an effect of monotony or flatness.

\section{Oriental Arborvitæ}

Biota orientalis

This tree and its varieties form a group of the choicest evergreens for formal effects, charming in their variations of coloring and in richness of texture and form. In its smaller stages the Oriental Arborvitae presents the appearance of a closepointed column and in later years assumes the habit of a rather loose-growing Red Cedar. Its color is a dark, rich green picked out with pretty, lighter green

NO CHARGE FOR PACKING 
points of the new growth. Together with the variety Conspicua, they are exceedingly valuable for vertical architectural accentuation and lend character to informal evergreen plantings.

$31 / 2$ to $4 \mathrm{ft}$

Each

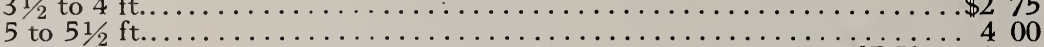

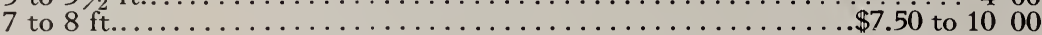

10

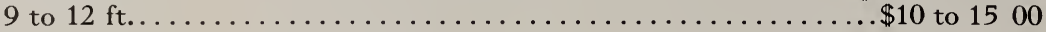

2500

3750

\section{Golden Columnar Oriental Arborvitæ}

Biota orientalis, var. aurea conspicua

A tall-growing sort, closely columnar in form and of a beautiful, golden green color; this variety and the other golden sorts are particularly pretty in winter when the wind exposes the inner twigs which are soft green against the rich bronze of the outer branches.

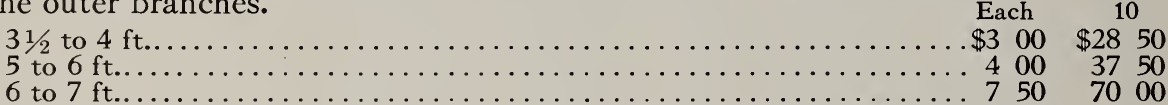

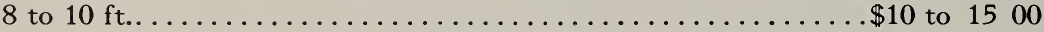

\section{Rollinson's Golden Oriental Arborvitæ}

Biota orientalis, var. elegantissima

Of medium height and of distinctly Japanese effect, with its branchlets of rich yellowish green in summer or deep bronze in winter standing out from its columnar form.

Each

10

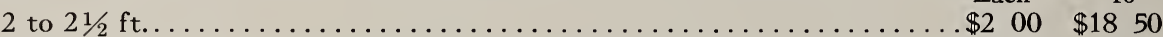

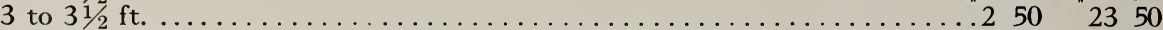

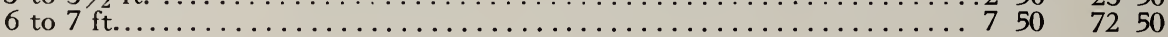

\section{Dwarf Golden Oriental Arborvitæ Biota orientalis, var. aurea nana}

In the spring the new growths give it the appearance of a rich gambogeyellow ball, slightly pointed at the top; very slow-growing.

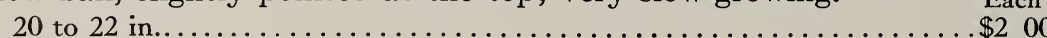

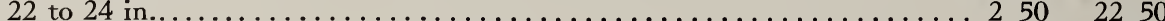

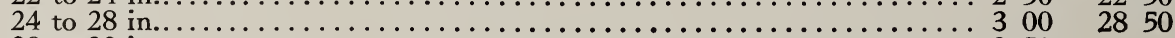

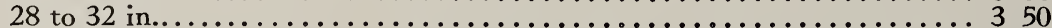

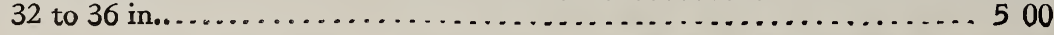

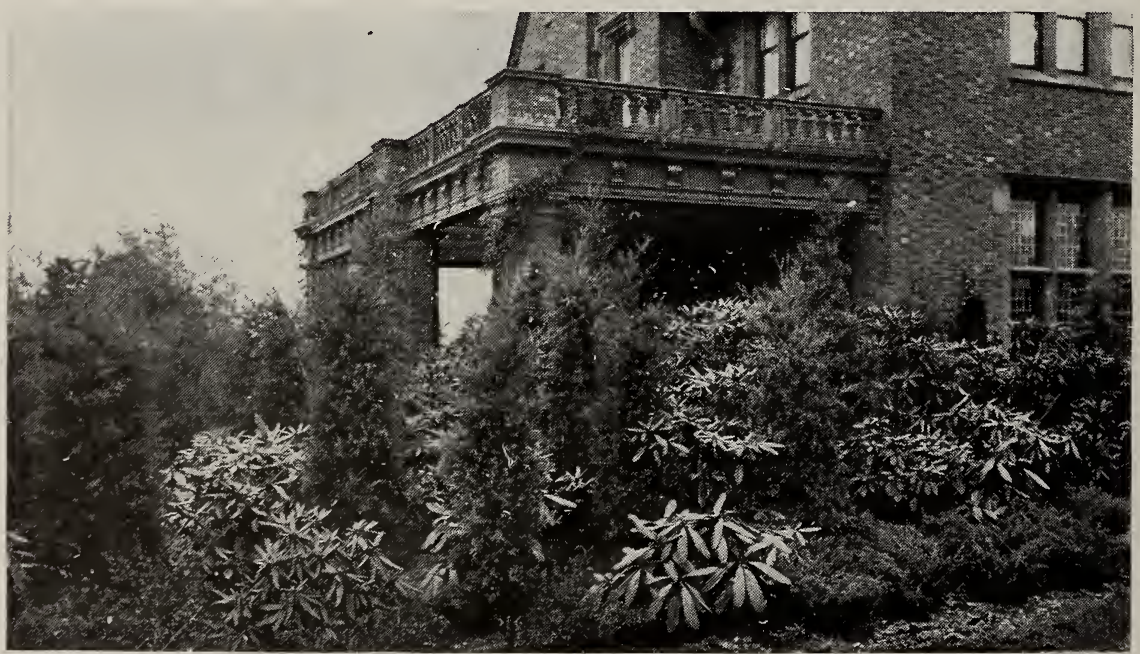

Shows the use of formal Evergreens in combination with those of an informal babit 
Compact Oriental Arborvitæ

Biota orientalis, var. compacta

Dwarf in habit and fresh, warm green in color, slow-growing.

3 to $31 / 2 \mathrm{ft}$

Each 10

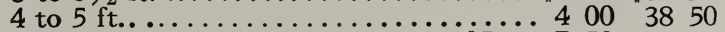

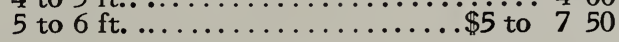

Dwarf Ever-golden Oriental Arborvitæ

Biota orientalis, var. semperaurescens

Bright golden green in the spring and retaining its color throughout the year.

$11 / 2 \mathrm{ft}$

Each

10

.$\$ 200 \quad \$ 1850$

\section{Japanese Cedar}

Cryptomeria japonica, var. Lobbii

The hardiest form of the Japanese Cedar. In Japan it has been planted in stately avenues many miles in length, the admiration of every visitor. In this country it approximates in shape the Red Cedar, but with much handsomer form of branches and needles of rich dark green in summer and in winter tinged with reddish bronze. We were among the first to introduce this plant and we recommend it highly.

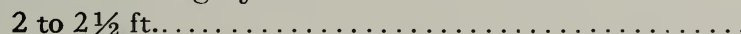

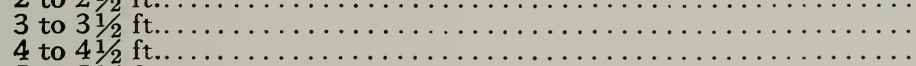

5 to $51 / 2 \mathrm{ft}$

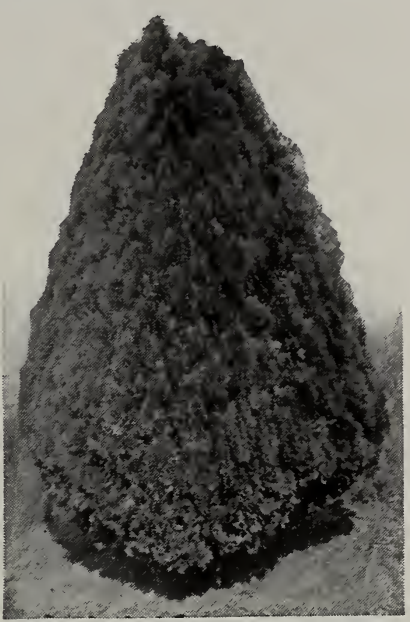

A neat specimen of the compact Oriental Arborvitæ

Each 10

$\$ 200 \$ 1850$

$250 \quad 2250$

$\begin{array}{llll}3 & 50 & 32 & 50\end{array}$

$500 \quad 4850$

\section{Cedars, or Junipers}

Juniperus

This interesting family provides us with some of the most desirable and useful small varieties where tall, narrow, columnar pointed trees of fine-textured foliage are desired in the design of formal gardens or where vertical lines of green are needed against a building. We do not handle any Red Cedars collected from the frelds, as they can usually be found growing wild, if the nature of the planting warrants the expense of moving very large trees with a ball of earth weighing several tons. Our Cedars are grown from seeds or cuttings in the nurseries, and so are provided with a large, compact system of fibrous roots that ensures their rapid growth. Superior to collected trees, ours are clothed with branches to the ground.

\section{Red Cedar}

Juniperus virginiana

When mature, this tree forms the nearest approach to the Italian Cypress, which, unfortunately, is not hardy here, but is quite like it in the beautiful play

of light and shadow with the sun shining on its dark green foliage. Each 10

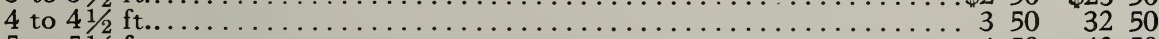

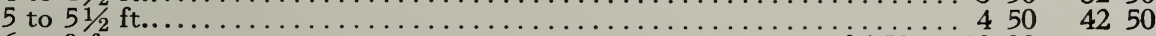

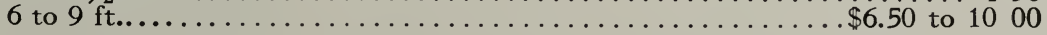

\section{Gray Cedar}

Juniperus virginiana, var. glauca

Similar to the above in form and of a soft gray-blue-green color; closely coIumnar.

Each

3 to $31 / 2 \mathrm{ft}$

$\$ 250$

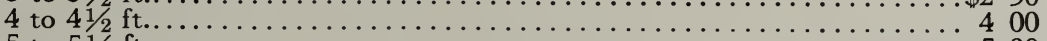

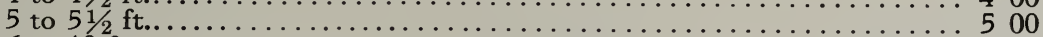

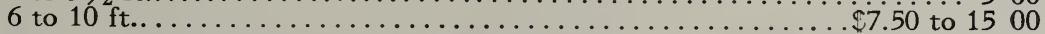


Fortune's Juniper Juniperus sphærica (fortunei)

Resembles the preceding, but slightly looser-growing. Introduced from northern China and rare. Each 10

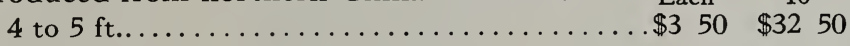

\section{Upright Juniper}

Juniperus communis

A dense, columnar shape of pleasing grayish green. Very valuable for its extreme hardiness even in the far North.

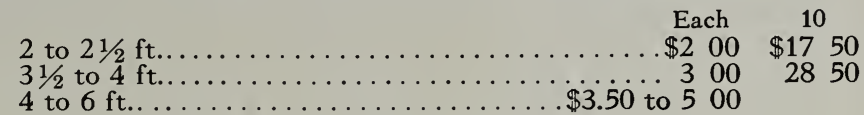

Irish Juniper

Juniperus communis, var. hibernica

Of slender columnar form; glaucous green foliage. Will keep "in scale" in small gardens.

$21 / 2$ to $3 \mathrm{ft}$.

Each

\$2 $00 \quad \$ 1850$

3 to $3 \frac{1}{2} \mathrm{ft}$.

$\begin{array}{rrrr}\$ 2 & 00 & \$ 18 & 50 \\ 2 & 50 & 23 & 50\end{array}$

\section{Swedish Juniper}

Juniperus communis, var. suecica

Resembles the above but not as compact in habit.

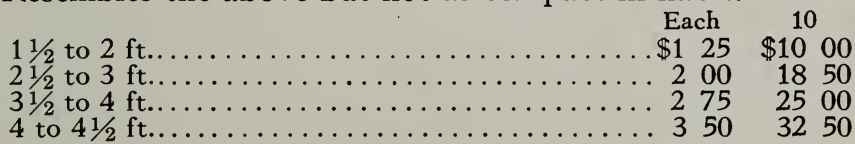

Caucasian Juniper

Juniperus communis, var. oblonga

A curiously symmetrical dwarf, presenting the appearance of a short column, flat on top and never but a few feet high and closely compact.

Each 10

$3 \mathrm{ft}$

.$\$ 350 \quad \$ 32 \quad 50$

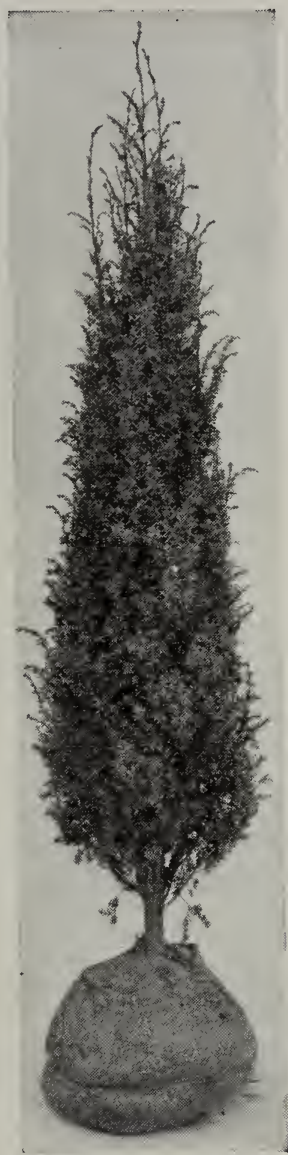

Irisb Juniper

\section{Ground Spruce}

Picea excelsa, var. Maxwellii

Forms a low, regular ball of closely bunched branches close to the ground, as does the next variety.

Each 10

$11 / 2 \mathrm{ft}$. . .

$\$ 2 \quad 50 \quad \$ 2350$

\section{Dwarf Spruce}

A tiny ball of dark green and very slow growing.

Picea excelsa, var. pumila

12 to 15 in

Each 10

$\$ 150 \quad \$ 1250$

\section{Pyramidal Norway Spruce}

Picea excelsa, var. pyramidalis

A variety forming a compact spire-form of medium height.

4 to $5 \mathrm{ft}$.

Each 10

.$\$ 350 \quad \$ 3350$

Japanese Table Pine (Tanyosho)

Pinus densiflora, var. globosa

It derives its common name from naturally forming a table-top of soft green a few feet high and wide. Covered in spring with "candles" of pinkish lavender. One of the most characteristic Japanese plants.

Each 10

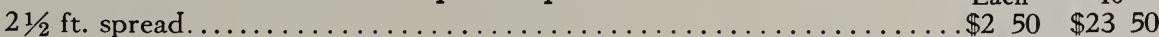

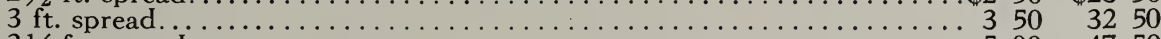

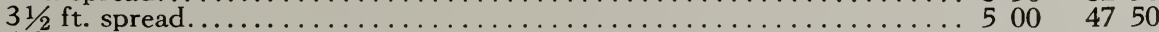

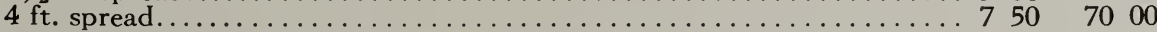




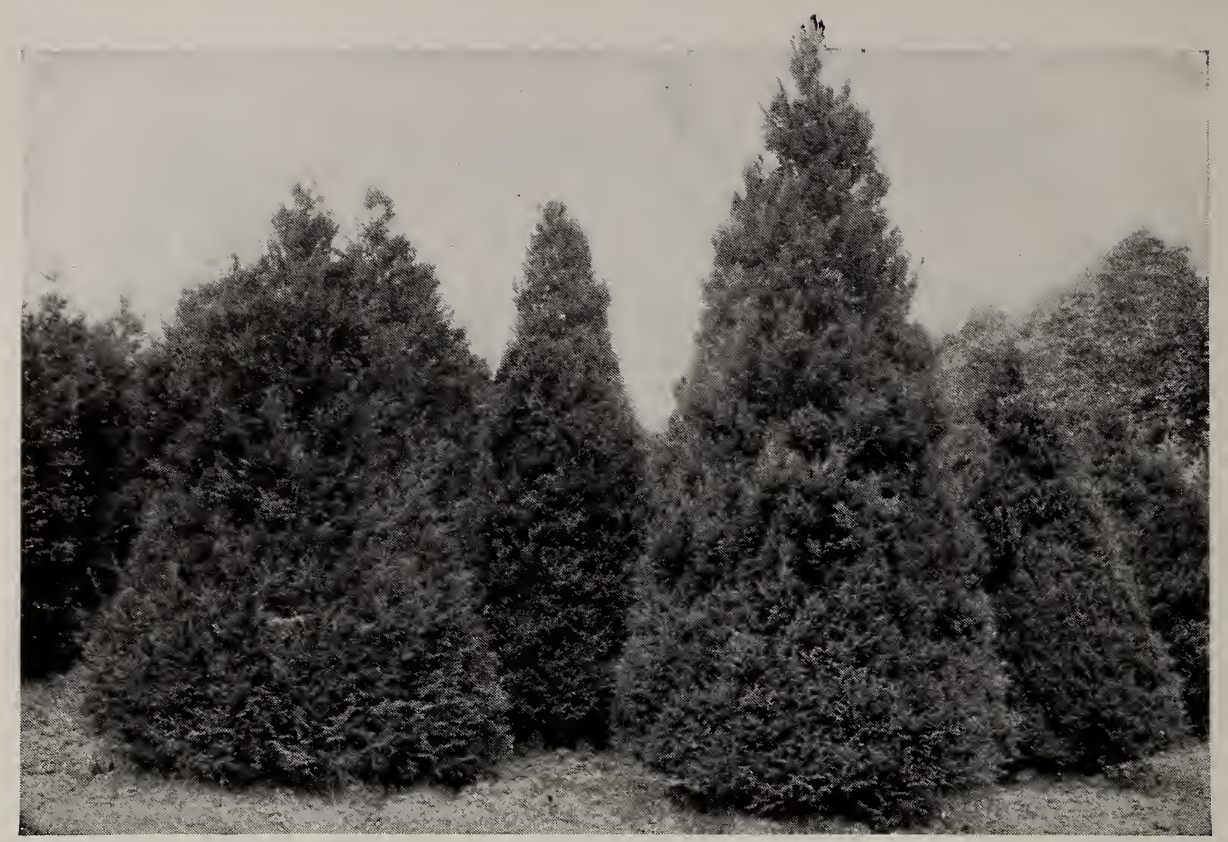

Showy forms obtained by clipping different varieties of Japanese Cypress

\section{Japanese Cypress}

Retinospora

This valuable family offers many trees and plants remarkably adaptable to formal work. Most of them are improved by being clipped, but possessed of beautiful naturaI forms, if left untouched. The following rarely attain a height of over twenty-frve or thirty feet and, as a study of the sizes which we offer will reveal, the taller plants will save many years, where an immediate effect is desired. Curiously the golden green forms are more hardy north of New York than the green. Nearly any of these varieties will make a very compact, thick hedge in a short time. The plants are trained in the nurseries to a robust columnar or rounded conical form, and the different varieties represent slight variations in the foliage.

Thread-branched Cypress

Retinospora filifera

Of medium growth and height. Foliage thread-like, of deepest green color.

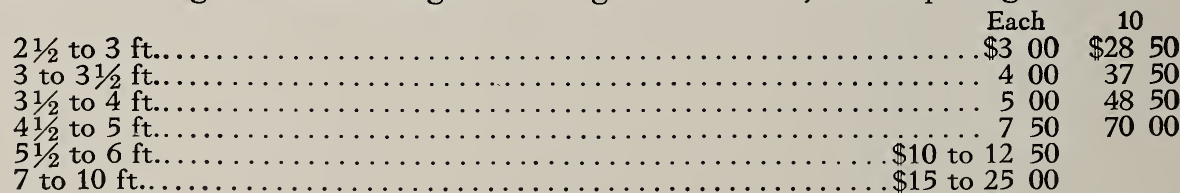

Golden Thread-branched Cypress Retinospora filifera, var. aurea

A golden-foliaged form of the above.

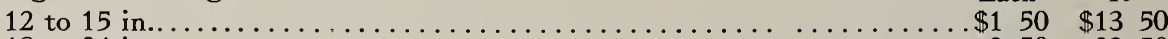

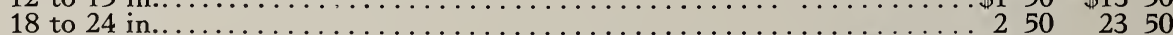

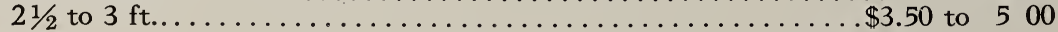

Pea-fruited Cypress

Retinospora pisifera

The tallest grower of the family. Broad, flat foliage, of deep glossy green.

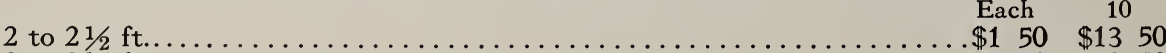

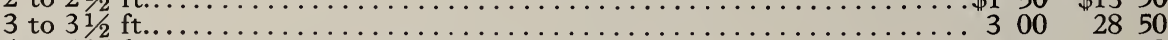

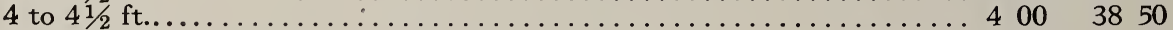

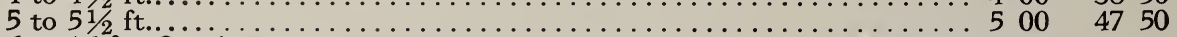

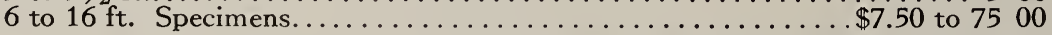


Golden Pea-fruited Cypress

Tall-growing, like the type.

$11 / 2 \mathrm{ft} \ldots$ Each

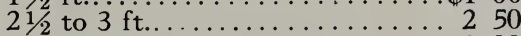

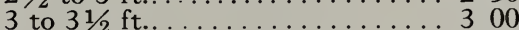

$31 / 2$ to $4 \mathrm{ft} . \ldots \ldots \ldots \ldots \ldots \ldots 350$

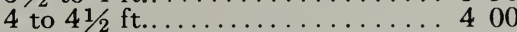

5 to $6 \mathrm{ft}$. Specimens......\$5 to 750

7 to $16 \mathrm{ft}$. Specimens.... \$10 to 7500

\section{Green-plumed Cypress}

\section{Retinospora plumosa}

\begin{tabular}{|c|c|}
\hline $\begin{array}{l}11 / 2 \text { to } 2 \mathrm{ft} \text {. } \\
2 \text { to } 21 / 2 \mathrm{ft} \text {. } \\
21 / 2 \text { to } 3 \mathrm{ft}\end{array}$ & 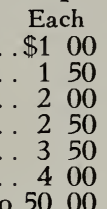 \\
\hline
\end{tabular}

\section{Golden-plumed Cypress}

\section{Retinospora plumosa, var. aurea}

One of the hardiest of its class.

$11 / 2$ to $2 \mathrm{ft}$

2 to $21 / 2 \mathrm{ft}$. . .

$21 / 2$ to $3 \mathrm{ft}$

3 to $31 / 2 \mathrm{ft}$

4 to $41 / 2 \mathrm{ft}$

$51 / 2$ to $6 \mathrm{ft}$

$61 / 2$ to $7 \mathrm{ft}$

$71 / 2$ to $8 \mathrm{ft}$
9 to $12 \mathrm{ft}$.

Silver-plumed Cypress

5 to $6 \mathrm{ft}$

Retinospora plumosa, var. argentea

Each $\$ 3 \quad 50 \quad \$ 32 \quad 50$

\section{Tree Cypress of Japan}

Foliage flat, held in half-whorls; color deepest green.

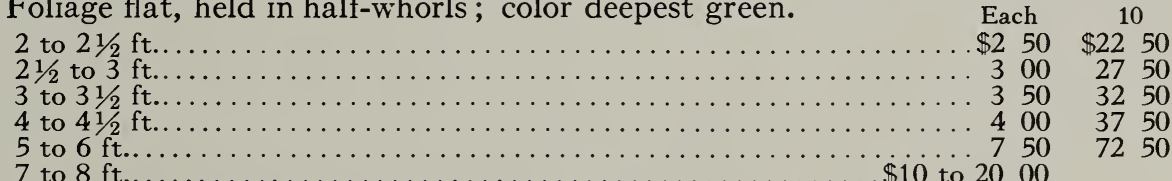

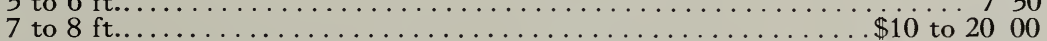

\section{Gray Cypress}

Retinospora squarrosa

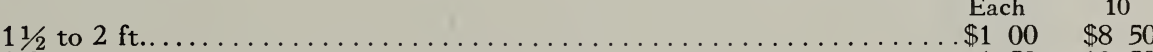

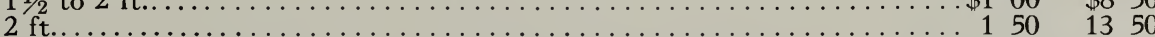

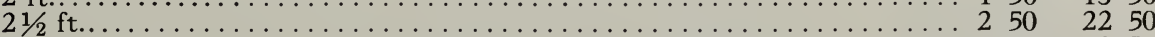

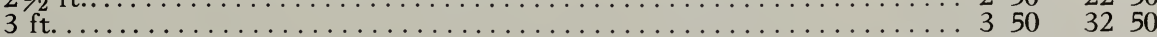

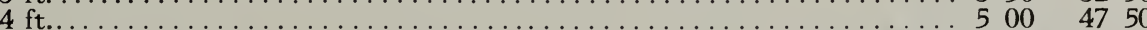

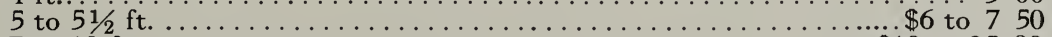

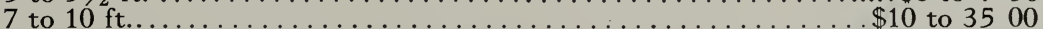

12 to $18 \mathrm{ft}$. Specimens........................... $\$ 50$ to 12500

\section{Gamboge-yellow Cypress}

Retinospora obtusa, var. Crippsii

Rather loose-growing. Throughout the year an intense warm yellow. Use for a high light or for warming up duIl corners.

$11 / 2$ to $2 \mathrm{ft}$ 


\section{THE FOLLOWING CYPRESS ARE OF LOWER GROWTH} and of rather symmetrical form; their interesting forms of foliage make them valuable additions to any planting.

\section{Thuya-like Cypress}

Retinospora leptoclada

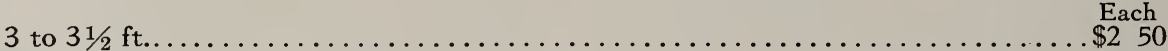

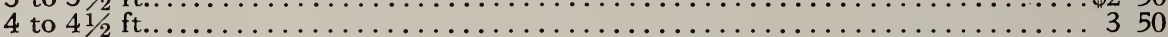

Club-moss Cypress

Retinospora lycopodioides

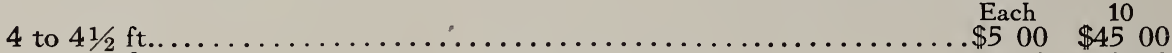

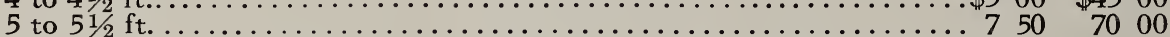

\section{THE FOLLOWING ARE SLOW-GROWING, DWARF FORMS}

\section{Dwarf Cypress}

Retinospora plumosa, var. flavescens

Similar to $R$. plumosa aurea, but of lighter color and broader form-rather a flat pyramid.

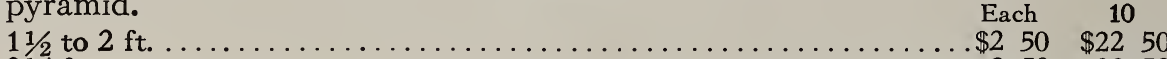

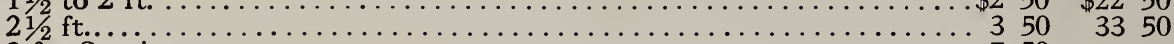

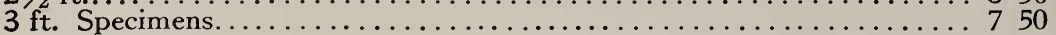

Heather-leaved Cypress

Retinospora ericoides

Especially good in the latitude of Washington and farther south.

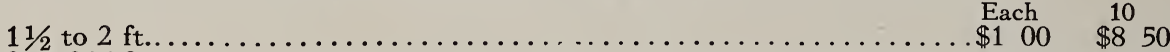

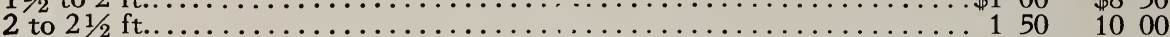

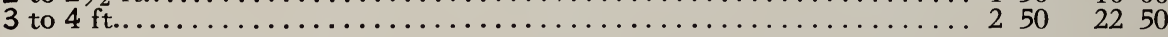

Sulphur-colored Dwarf Cypress Retinospora plumosa, var. sulphurea

In the spring it assumes a soft sulphur-yellow greenish tone; it is very compact, a squat bulb-shape; thoroughout the year its soft, light green shades are effective.

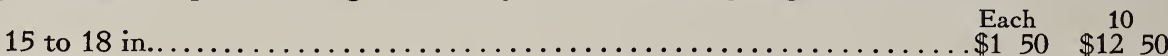

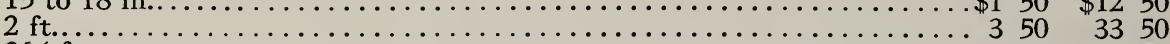

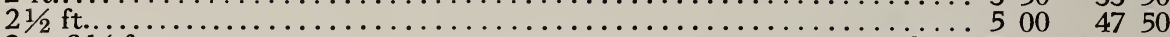

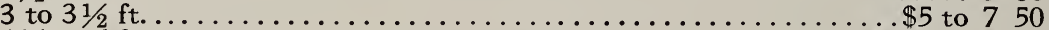

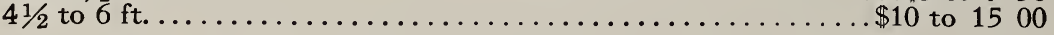

Compact Cypress

Retinospora obtusa, var. compacta

Compact and bushy in form, of dark green color.

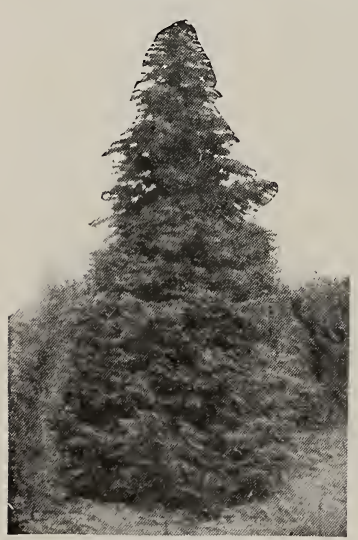

Dwarf Garden Cypress

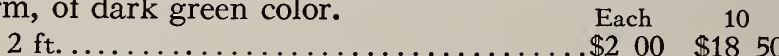

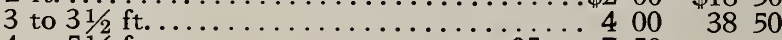

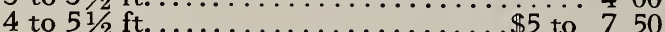

\section{Dwarf Garden Cypress}

Retinospora obtusa, var. nana

The variety used by the Japanese with their methods of root-pruning and checking to produce the picturesque miniature trees grown in pots. Naturally of very slow growth, the rich, dark green color and refinement of contour make this one of the most highly desirable evergreens for formal gardens or specimens. Each 10

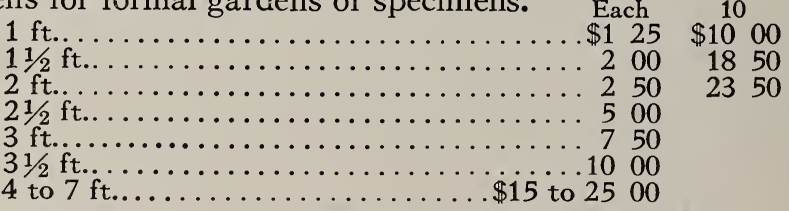

ANDORRA NURSERIES 


\section{Golden Dwarf Garden Cypress}

\section{Retinospora obtusa, var. nana aurea}

Like the preceding, with tips of leaves touched with bronze in winter and in early spring clothing itself in warm shades of golden green. This variety and the green form are among the best for use in gardens or in plantings at the base of the house or terrace as its very slow growth keeps it in proper scale with architectural details indefinitely. They may also be attractively used as pot- or tub-plants and they are, of course, especially fitting in Japanese gardens.

Each 10

$2 \mathrm{ft} \ldots \ldots \ldots \ldots \ldots \ldots \ldots 250 \quad \$ 23 \quad 50$

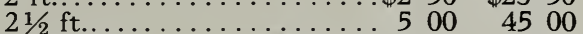

3 to $31 / 2 \mathrm{ft} . \ldots \ldots \ldots \$ 7.50$ to 1000

4 to $10 \mathrm{ft}$.........\$12.50 to 5000

\section{Umbrella Pine}

\section{Sciadopitys verticillata}

Another tree characteristic of Japan in its feeling. Compact, slow-growing, narrowly conical in shape. Each 10

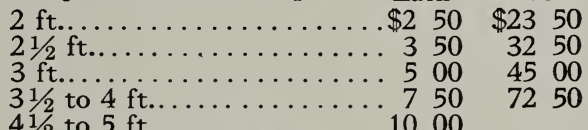

6 to $8 \mathrm{ft} \ldots \ldots \ldots \ldots \$ 12.50$ to 2500

\section{Irish Yew}

Taxus baccata, var. fastigiata

Dense, dark green and severe in its

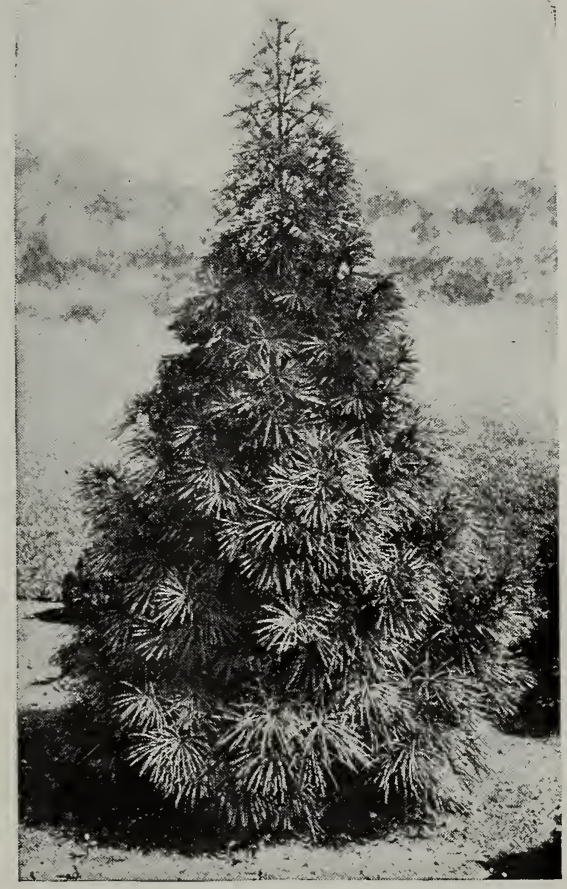

Umbrella Pine narrow pointed habit, it is extremely useful on account of its slow growth, where plants must be kept in scale. Each 10

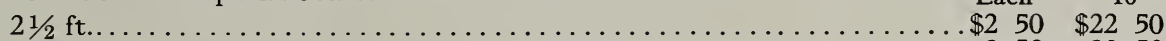

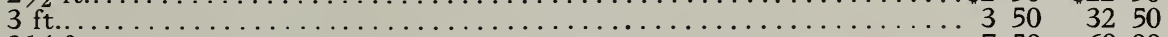

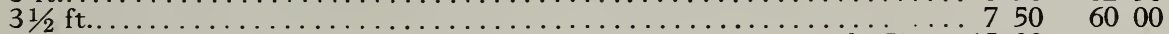

4 to $6 \mathrm{ft}$. Specimens.................................. $\$ 7.50$ to 1500

Golden Irish Yew

Taxus baccata, var. fastigiata aurea

Tinged with dull bronze, it resembles the above in every detail. Each 10

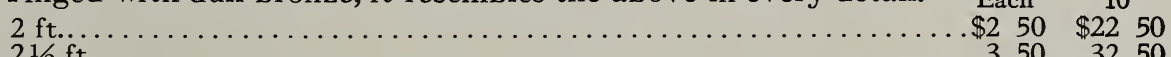

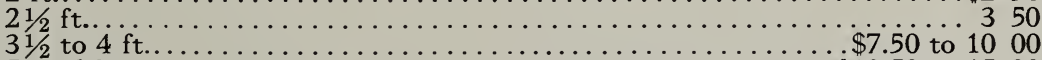

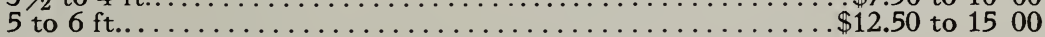

\section{Gray Sitka Cedar}

A trim, symmetrical, upright tree of medium height with handsome gray-green foliage, and hardy north of Long Island in protected positions only. A very good tree for use in tubs and pots in gardens or on terrace. One of the most desirable and individual for formal effects.

3 to $31 / 2 \mathrm{ft}$.

Thuyopsis borealis, var. latifolia glauca

(Chamaecyparis nutkaensis)

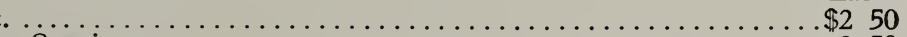

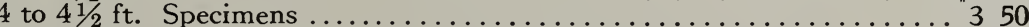

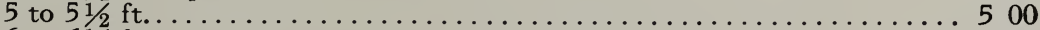

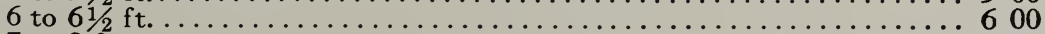

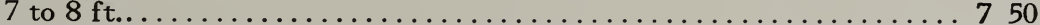

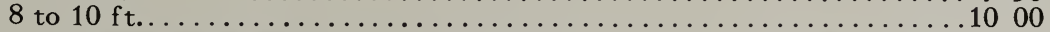




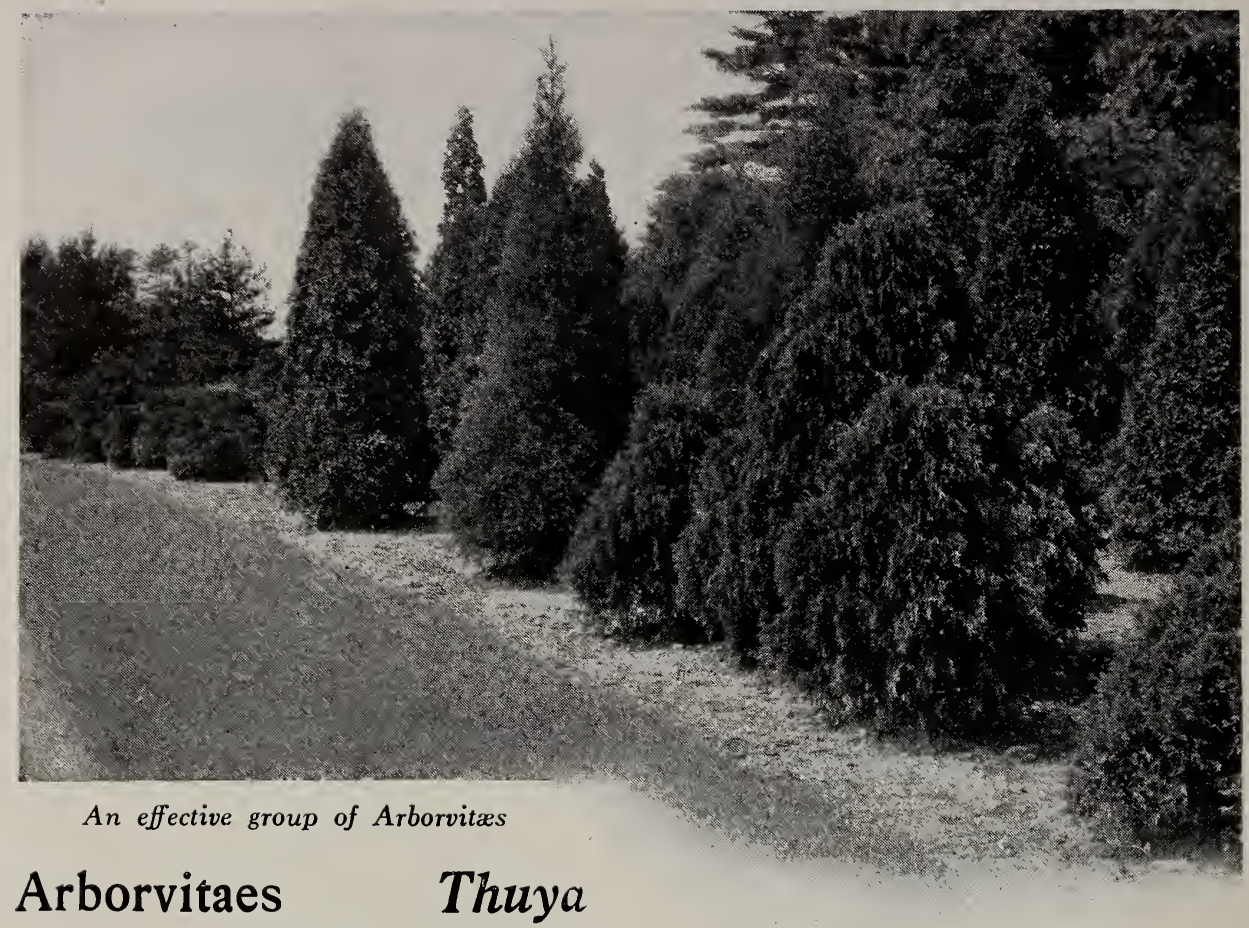

Of the many plants suitable for formal effects the varieties of Arborvitæ are preëminently frtting, on account of their naturaily compact habit of growth, because they may be kept clipped in hedges or any desired form, and for the neat, clean appearance of their thick fan-like foliage. They may be planted in a wide variety of soils and exposures, with happy results, or may be used for tubplants. They are useful where Boxwood will not stand the winters.

The first group is distinctive for their thin columnar form and attain a height of 20 feet or more, while the second group is of rather broader growth and not quite so tall; the third group comprises varieties markedly dwarf and symmetrical.

\section{FIRST GROUP - TALL COLUMNAR}

\section{American Arborvitæ}

Thuya occidentalis

AII wonderfully well-grown plants with large balls of fibrous roots.

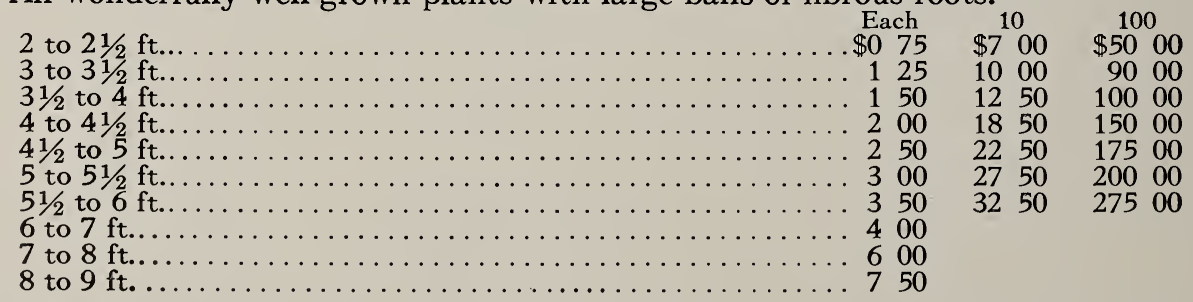

George Peabody's Arborvitæ

Thuya occidentalis, var. aurea

Foliage of a pleasing golden green; otherwise like the above. Each 10

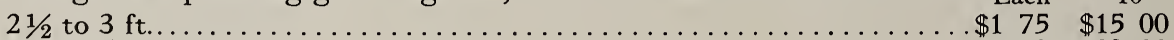

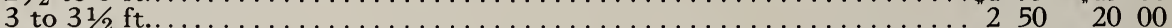

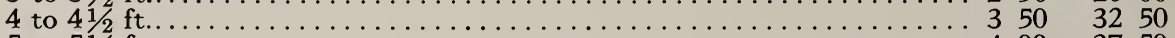

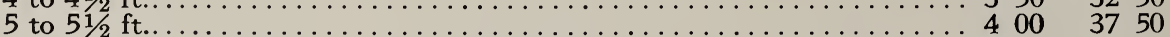

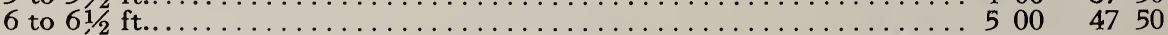

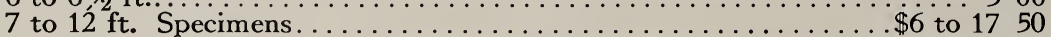


Rosenthal's Arborvitæ

Thuya occidentalis, var. Rosenthali

Of medium growth and columnar habit; color deep green.

Each 10

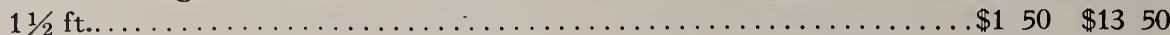

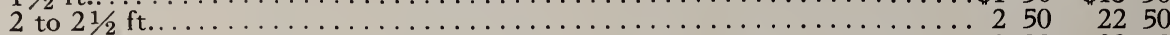

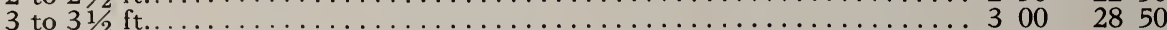

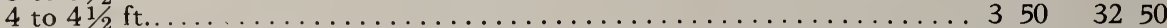

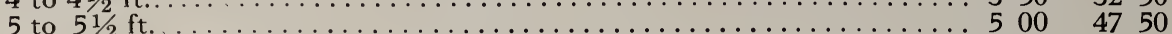

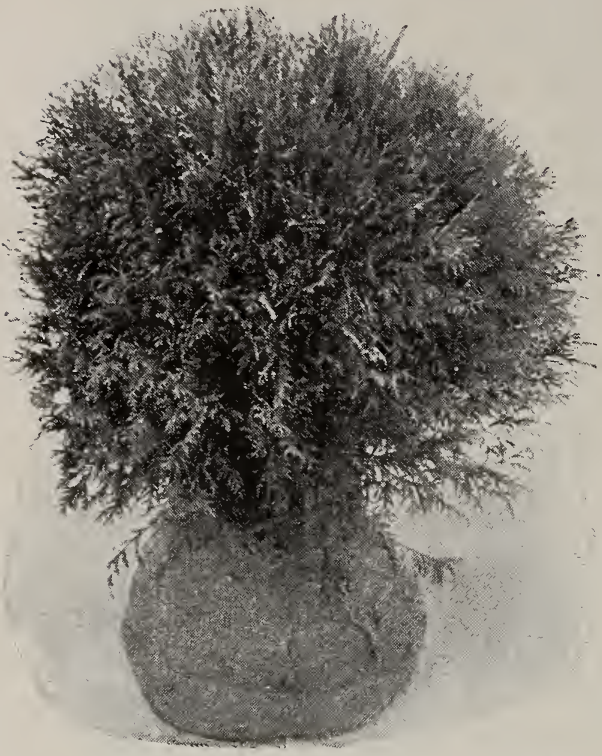

The neat, compact Globe Arborvitæ

\section{THIRD GROUP • DWARF}

These varieties naturally form a close, compact ball of green, very slow-growing, and desirable in situations too cold for Boxwood.

\section{Heath-leaved Arborvitæ}

Thuya occidentalis, var. ericoides

Globe-shaped or broadly pyramidal.

2 to $21 / 2 \mathrm{ft} . \ldots \ldots \ldots \ldots \ldots \ldots \$ 200 \quad \$ 1500$

\section{Ellwanger's Arborvitæ}

Thuya occidentalis, var. Ellwangeriana

A low, broad pyramid.

Each 10

2 to $21 / 2 \mathrm{ft} . \ldots \ldots \ldots \ldots \ldots \ldots 250 \$ 2250$

\section{Globe-shaped Arborvitæ}

Thuya occidentalis, var. globosa

Bright green in color.

Each $\quad 10$

15 to 18 in..............\$1 $50 \$ 1350$

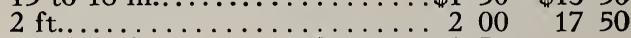

$2 \frac{1}{2}$ to $3 \mathrm{ft} . \ldots \ldots \ldots \ldots 250$ to 350

Thuya occidentalis, var. recurva nana

Dwarf Arborvitæ

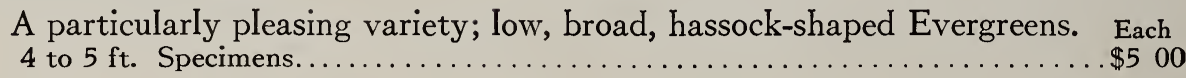

Tom Thumb Arborvitæ

Very dwarf and compact.

Thuya occidentalis, var. Tom Thumb

12 to 15 in...

Each 10

$\$ 150 \quad \$ 1350$

\section{Arborvitae Hedges}

On account of its rapid growth and hardiness and because it Iends itself readily to trimming, the American Arborvitæ (Thuya occidentalis) is one of the best Evergreens for tall hedges, while the dwarfer varieties are equally useful in situations where a low hedge or edging is required.

This plant is also capable of great utility in the working out of formal designs, clipped in architectural forms, in gardens, and in training in the shape of arches over paths and gateways.

Where a hedge of rather irregular outline is desired and where it is not planned to keep it closely trimmed, the Siberian Arborvitæ ( $T$. occidentalis, var. Wareana) is to be recommended. This type carries much more breadth in proportion to its height than any of the others, and by slightly stopping the top growth as much width can be had at the top as at the base. Its rather rugged contour and its most pleasing texture of foliage and great hardiness make it one of the most desirable hedges where a growth not exceeding 6 feet in height is desired. 


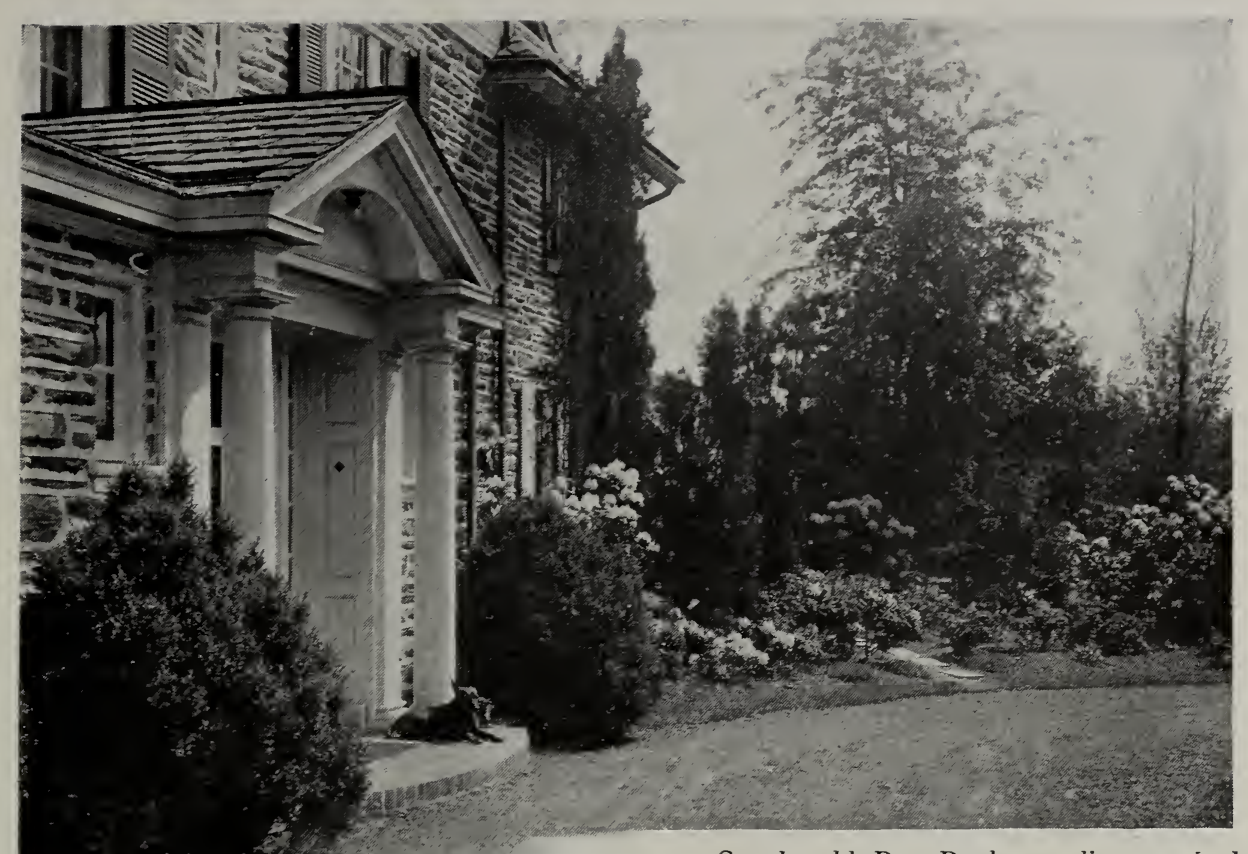

Stately old Box Busb standing sentinel at the door add a touch of quiet ricbness as no otber plant does.

\section{Evergreens for Formal Effects $\cdot$ Boxwood}

7 HE note of greatest charm and dignity in old American gardens and about venerable houses and estates, softened by time and planting, is oftenest that of Boxwood, in the play of light and shade on long dark green hedges or in grand old specimen plants, but always expressive of refinement and permanence. With remarkable foresight the management of the Nurseries set aside a large number of Boxwood nearly twenty years ago to be allowed to grow to large sizes. During that time they have been frequently transplanted so that today we can offer Boxwood bushes, up to 6 feet in height and almost as broad, that have taken on the beautiful modeling of billowy contour and the rich appearance of pompous guardians of some old Colonial house or garden. These plants move with a tremendous ball of fine fibrous roots and loam, and so obviate the risk of loss ordinarily attendant on moving plants from old places, where they have grown long wandering roots bare of fiber, making them difficult to transplant.

Some confusion arises at times in regard to the varieties of Boxwood, and to obviate it, we deem it of interest to explain that the plants ordinarily called Box Bush are Buxus sempervirens, which may in the course of years grow to a height of 10 feet, but always maintains a close habit of growth. Buxus sempervirens, var. arborescens is the true Box Tree, and while resembling the Box Bush in its habit of growth in early years, attains at a greater age a height sometimes of 15 feet or more, and is the 


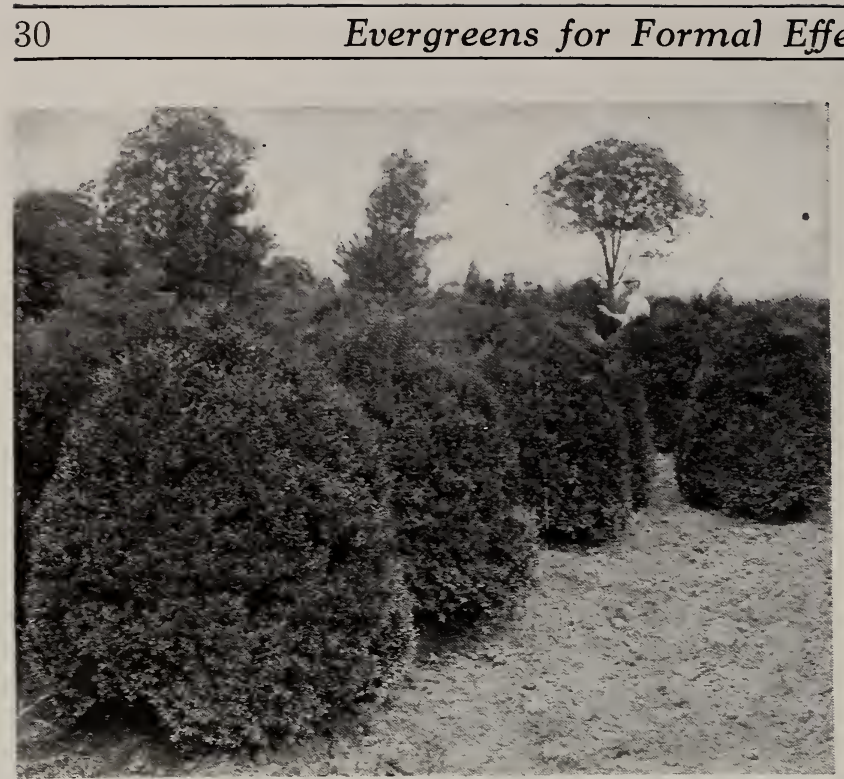

Specimen Box Busb growing at Andorra

open-growing, graceful tree, usually with a number of stems branching from the ground, to be seen about old homesteads. This variety stands shade better than the others.

Then there is the Dwarf Box, B. sempervirens, var. suffruticosa, which has been used for the neat low edging of garden-beds from earliest times, and of very slow growth, hedges perhaps a hundred years old being still less than 2 feet high. Dwarf Box and Box Bush can be clipped almost indefinitely, to maintain any desired height or shape, and so both may be used for hedges, depending on the height desired.

AII the Boxwood which we offer is grown in our Nurseries and, unlike the Boxwood usually sold, is thoroughly acclimated; the loss ratio on Dutch Box freshly imported from Europe is usually very high.

The illustration at the top of the page gives a graphic idea of the size and character of the specimens which we offer. These plants lift with a huge ball of roots and, securely packed and crated, can be shipped to any distance.

\section{Box Bush}

Buxus sempervirens

Bush-shaped, from two-thirds to nearly as broad as the plants are high. We caII especial attention to the handsome, large-sized plants unobtainable elsewhere. Among these are some rare, old specimens.

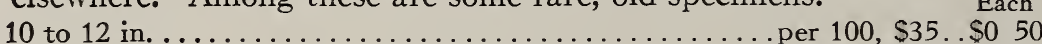

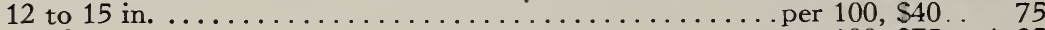

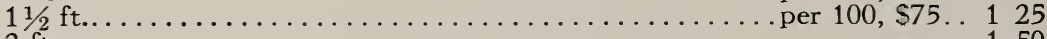

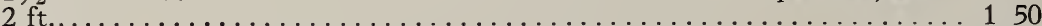

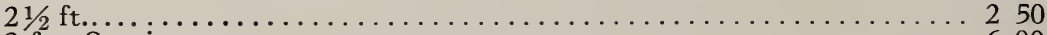

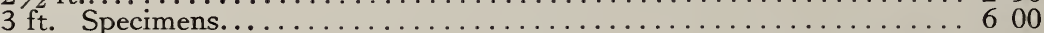

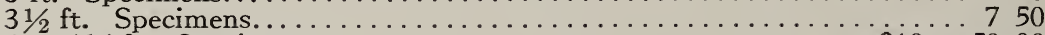

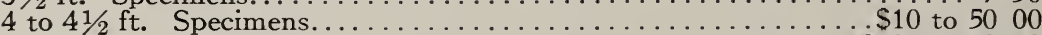

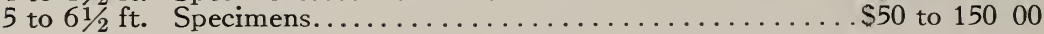

Pyramid-shaped, some of which have been allowed to Iose the usual narrow form and are extra heavy at the bottom.

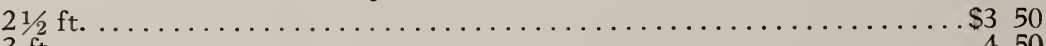

$3 \mathrm{ft}$

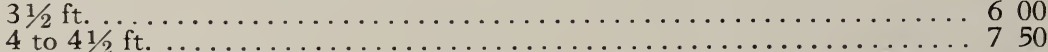

600

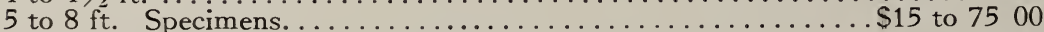

Globe-shaped describes the form of these plants.

18 to 20 in.

Each

20 to 22 in 


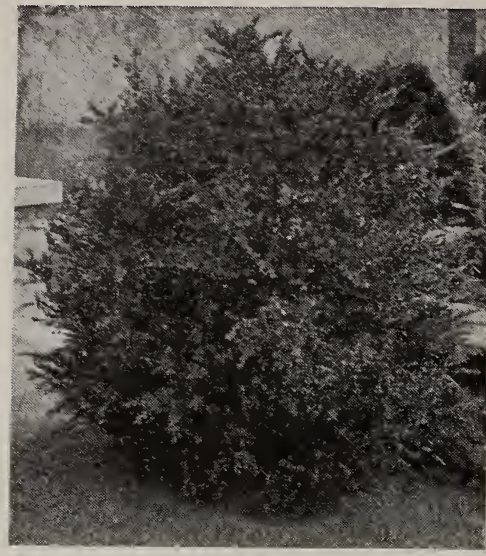

Box Tree

\section{Myrtle-leaved Box Bush}

Buxus sempervirens, var. myrtifolia

Close-growing, very dark green leaves.

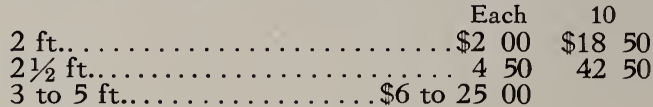

\section{Golden-tipped Box}

Buxus sempervirens, var. angustifolia variegata

Pretty, golden variegation. This type is of free open growth, and can be used to advantage in mass plantings with the smaller-growing Evergreens.

4 to $41 / 2 \mathrm{ft}$. Specimens........\$7 $50 \$ \$ 7000$

5 to $6 \mathrm{ft}$. Specimens.....\$10 to 1500

\section{Silver-tipped Box}

Buxus sempervirens, var. argentea marginata Tipped with silver, otherwise similar to type.

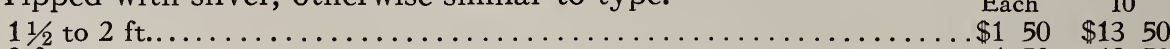

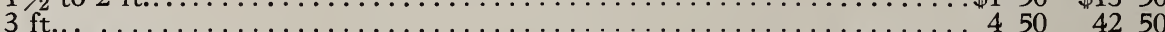

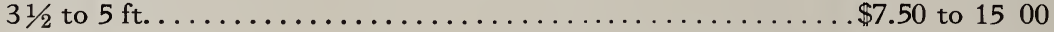

\section{Box Tree}

Buxus sempervirens, var. arborescens

The Iarger sizes which we offer have already begun to take on the loose, gracefuI, natural habit of this variety; tree grows to a height of 15 or 20 feet.

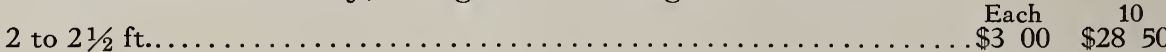

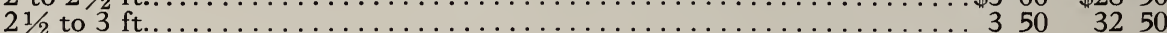

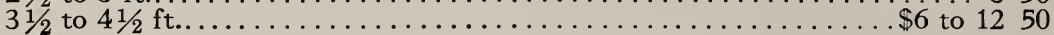

Dwarf Box

The smaller sizes are the plants par excellence for edging of flower-beds or for parterres; the larger plants are useful as small dots of green in garden designs.

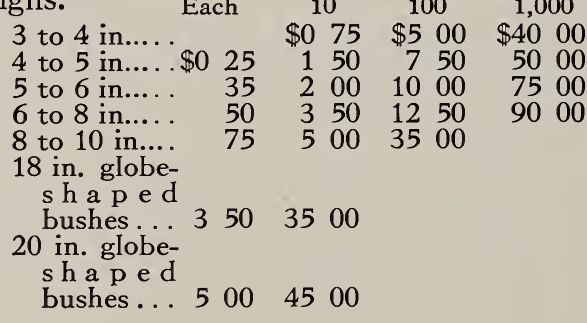

\section{Clipping Boxwood}

When Boxwood is trained to various shapes or is used in hedges, it should be clipped in the spring just before the buds of the new growth start, so as to produce a close compact surface. In the case of the Dwarf Box very little trimming is necessary on account of its naturally slow growth. In any case, trimming should not cut back to the old wood.

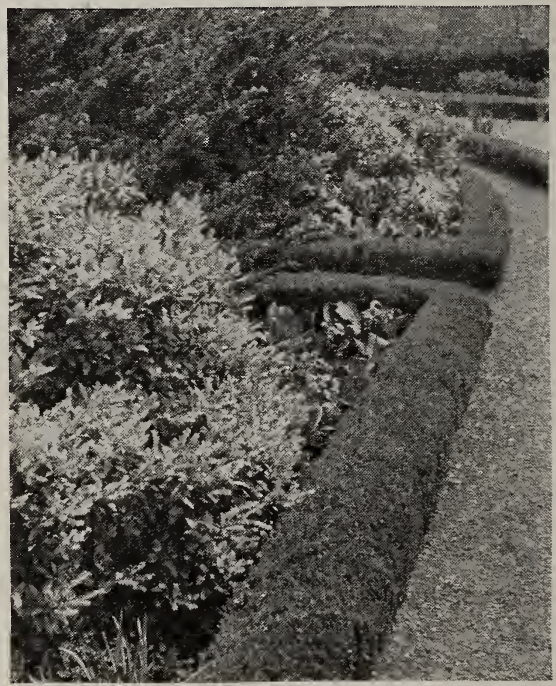

Box-edging surrounding garden beds 


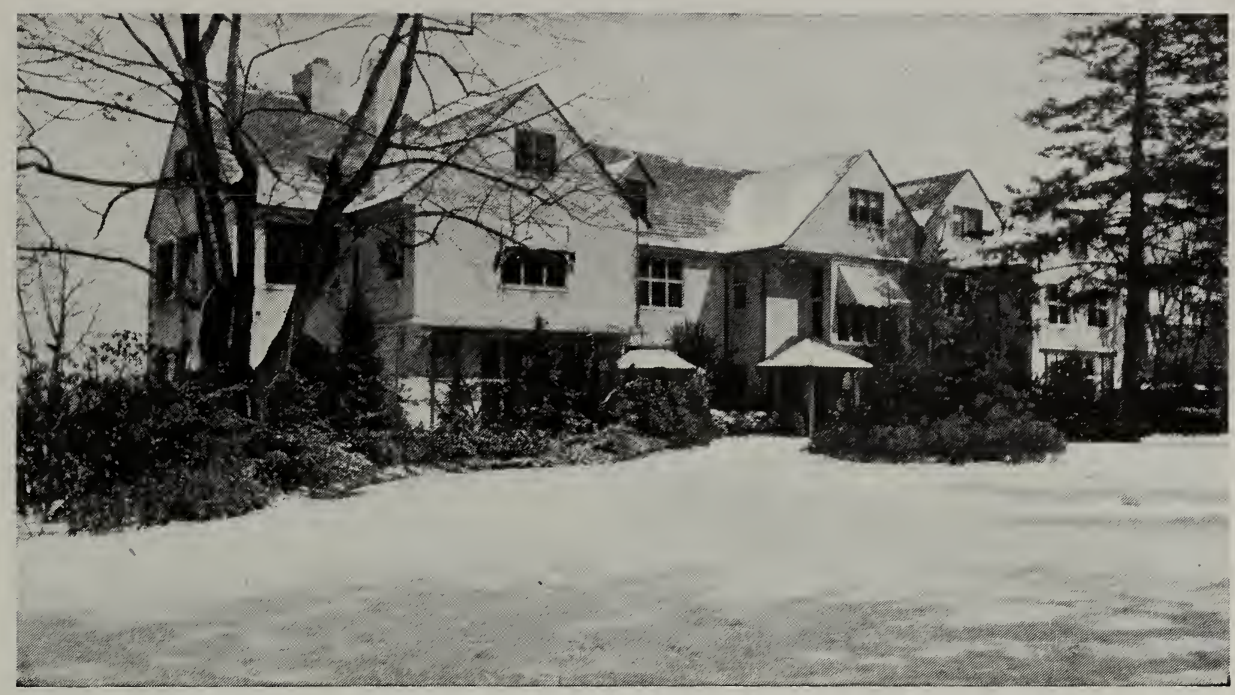

In midwinter the effect in Evergreen planting lends warmth and cheerfulness

\section{Evergreens for Informal Plantings Conifers}

7 HE American habit of life and thought, the architectural style of our houses and the amplitude of our suburban and country life has had a tendency to make us lean more easily to informal than formal arrangements of planting, and more and more we appreciate the charm and pleasure that is given by a strong admixture of Evergreens in the planting about our homes. No matter how attractive the coloring or how pleasant the promise that bare twigs and branches hold for spring, still the warmth and cheer expressed by Evergreens during the winter months is always most grateful. Although their attractiveness is just as effective under the hot sun of summer or in the fall when the beauty of deciduous shrubs is in their falling leaves, still we think of the Evergreens in the following pages especially as cheerful winter neighbors.

\section{CONIFERS • SMALL-LEAVED EVERGREENS}

These varieties, together with many of the compact-growing formsespecially the tall ones that we have listed under "Evergreens for Formal Effects" (see page 29), and those which come under the category of "Flowering Broad-leaved Evergreens" (see page 41) - comprise a group of plants which are unequaled as a source of pleasure and for effectiveness the year round. For planting about the base of the house; for borders or masses of ever-changing interest from season to season; for use in rockgardens, which so often are lonesome in winter if dependence is placed entirely upon perennials; or for specific uses, as Evergreen gardens or Japanese effects, our Evergreens offer a wide variety for your selection. In growing these plants, we have adhered to a policy of "quality above all." 


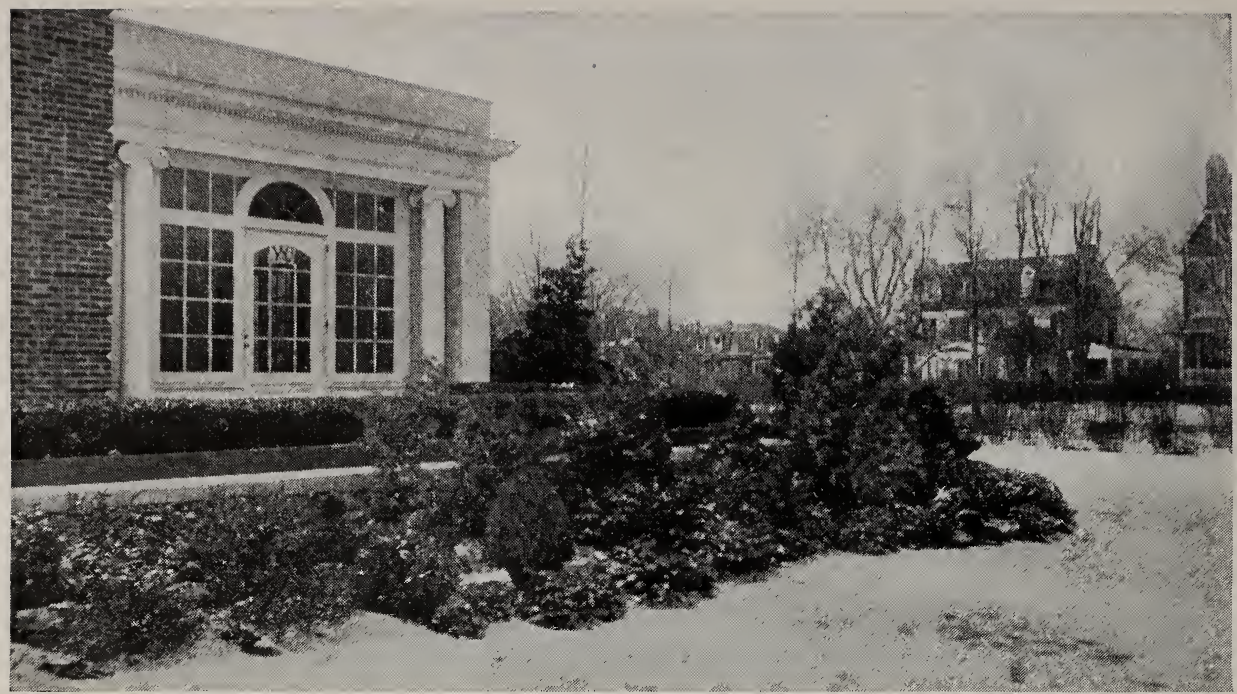

The informal planting of Evergreens successfully softens the base-line of the bouse and terrace

\section{TREES OF MEDIUM HEIGHT}

Thread-branched Oriental Arborvitæ Biota orientalis, var. filiformis

Slender, drooping branches, light green foliage, bushy, hardy. Each 10

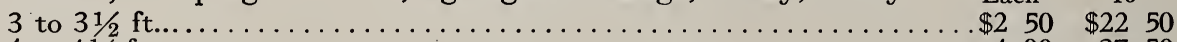

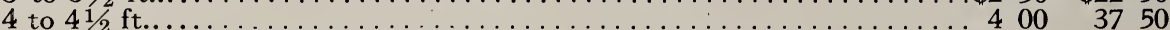

\section{Cedar of Lebanon}

Cedrus libani

Wide-spreading tree of dark green foliage; picturesque in the extreme. Somewhat tender north of the latitude of New York.

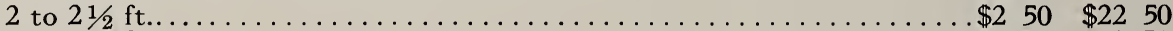

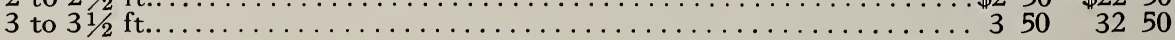

Japanese Cedar

A forest tree in Japan, here a pyramidaI tree of decidedly Japanese appearance

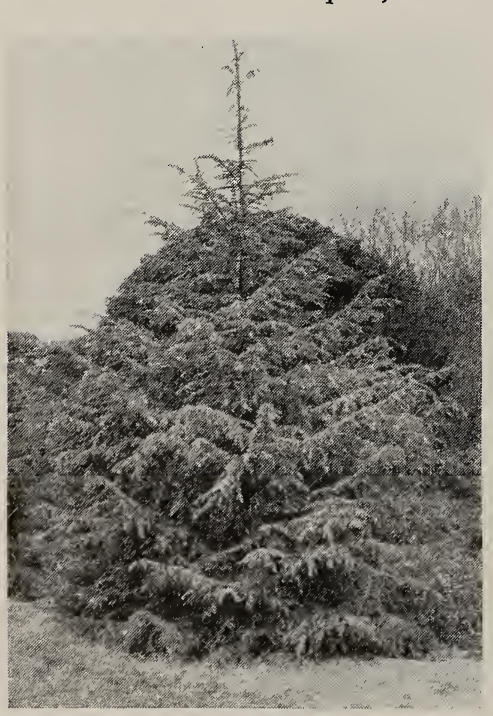

Cedar of Lebanon and medium height. Not hardy north of Long Island.

Each 10

3 to $4 \mathrm{ft} . \ldots \ldots \ldots \ldots \ldots \ldots \ldots \ldots \ldots \$ 300 \quad \$ 2850$
4 to $5 \mathrm{ft} . \ldots \ldots \ldots \ldots \ldots \ldots \ldots \ldots \ldots$
6

6 to $7 \mathrm{ft} . \ldots \ldots \ldots \ldots \ldots \ldots \ldots \$ 5$ to 1000

Japanese Temple Cedar

Cryptomeria japonica, var. dacrydioides

4 to $5 \mathrm{ft} \ldots \ldots \ldots$

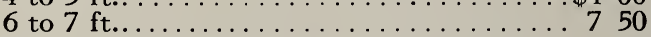

\section{Upright Chinese Juniper}

Juniperus chinensis, var. femina (Reevesii)

A shrubby form of rather loose conical appearance, growing into a small- to mediumsized tree. Its habit lends itself readily to mixed planting.

Each 10

2 to $21 / 2 \mathrm{ft} . \ldots \ldots \ldots \ldots \ldots \ldots \ldots . \ldots 200 \$ \$ 1850$

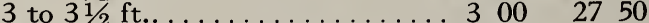

4 to $4 \frac{1}{2} \mathrm{ft} . \ldots \ldots \ldots \ldots \ldots \ldots \ldots \ldots 400 \quad 3750$

6 to $8 \mathrm{ft} \ldots \ldots \ldots \ldots$ to 1000 
Pfitzer's Juniper

Juniperus chinensis, var. Pfitzeriana

A graceful, broad, pyramidal Evergreen with sweeping fronds of gray-green foliage making in time a distinctive, beautiful tree. Our larger sizes are taking on their pleasing habit not usually seen in this new introduction. Each 10

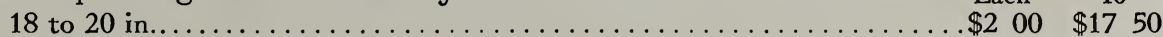

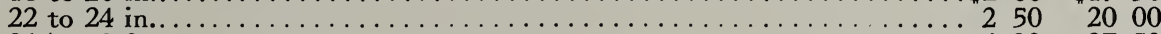

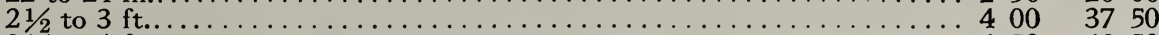

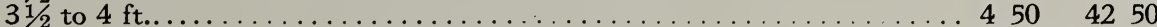

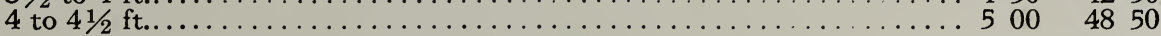

Pendulous Red Cedar

Juniperus virginiana, var. pendula

The slender, pendulous branches create a very striking effect. Each 10

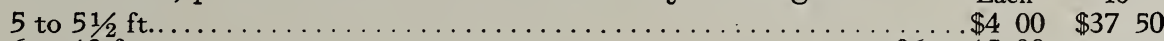

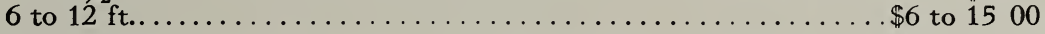

Plume-tipped Red Cedar

Juniperus virginiana, var. plumosa

Pleasing, feathery appearance.

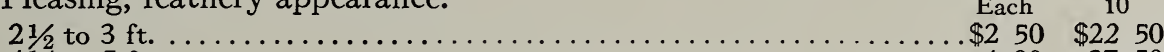

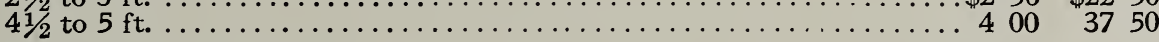

Tall Japanese Juniper

Juniperus rigida

Like many other natives of Japan, this tree possesses great individual merit as a graceful, hardy small tree or large shrub with yellowish green foliage. Each

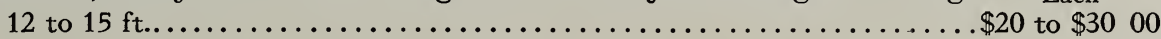

\section{Gregory's Spruce}

A dense-growing, conical-shaped tree.

$2 \mathrm{ft}$

Weeping Norway Spruce
Picea excelsa, var. Gregoryana

Each 10

.$\$ 300 \quad \$ 28 \quad 50$ green needles.

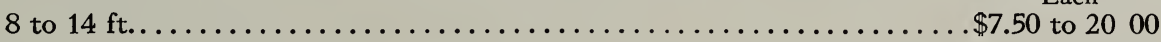

Weeping Colorado Blue Spruce

Rare and interesting in form and color.

3 to $5 \mathrm{ft}$. Specimens.

Picea pungens, var. pendula

Picea excelsa, var. inverta
g almost perpendicularly; dark Oriental Yew

An upright shrubby tree with shining, dark green foliage.

2 to $21 / 2 \mathrm{f}$

Each

. $\$ 5$ to $\$ 1000$

English Yew

Taxus baccata

It is unfortunate that all the varieties of this plant so universally used in England for hedges and in clipped forms are not hardy north of New York, as nothing is more impressive than its beautiful black-green color in the landscape; it should be planted in the North in rather protected situations. Many of the plants catalogued below are especially large and fine and will at once lend character to any place in which they are planted. The varieties are all interesting.

Each

2 to $21 / 2 \mathrm{ft} . \ldots \ldots \ldots \$ 250$

3 to $31 / 2 \mathrm{ft} \ldots \ldots \ldots \ldots 350$

10

4 to $41 / 2 \mathrm{ft} \ldots \ldots \ldots \ldots 750$

$\$ 2350$

5 to $6 \mathrm{ft}$.....\$10 to 1500

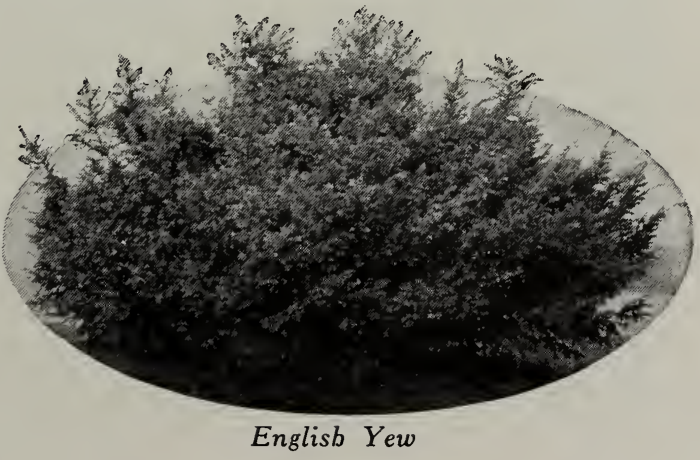

NO CHARGE FOR PACKING 
Elegant English Yew

Taxus baccata, var. elegantissima Hardy much farther north than $T$. baccata. Of close dense growth; rich yellow coloring, bronzing in the winter.

Each

2 to $21 / 2 \mathrm{ft}$

3 to $4 \mathrm{ft}$.

$\$ 2.50$ to $\$ 350$

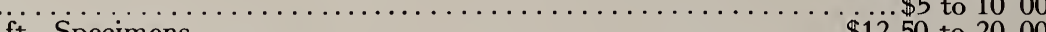

\section{Dovaston's Yew}

Taxus baccata, var. Dovastonii

In hardiness equal to $T$. baccata, in form loose and spreading, the branches pendulous at the tips.

Each

5 to $6 \mathrm{ft}$

$\$ 7.50$ to $\$ 1000$

Dovaston's Golden Yew

Taxus baccata, var. Dovastonii aurea

The hardiness and form are equal to the above but the foliage is flushed with golden yellow.

4 to $10 \mathrm{ft}$. Specimens.

Each

.$\$ 7.50$ to $\$ 5000$

\section{Erect English Yew}

Taxus baccata, var. erecta

Rather formal in outline and hardy as far north as Long IsIand.

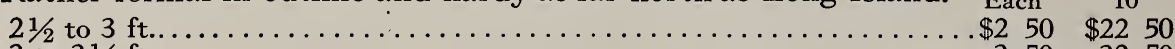

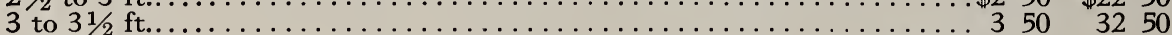

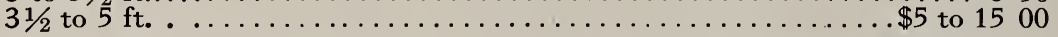

Erect Golden English Yew

A golden form of the above.

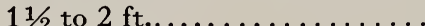

Taxus baccata, var. erecta aurea

2 to $21 / 2 \mathrm{ft}$

10

3 to $4 \mathrm{ft}$

250

$\$ 1850$

\section{Washington's Golden English Yew}

Taxus baccata, var. Washingtonii aurea

Of unquestioned hardiness, a beautiful Yew for informal planting or may be trimmed to broad, formaI shapes.

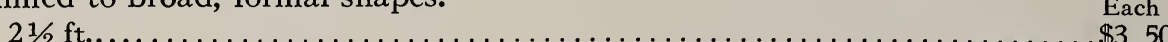

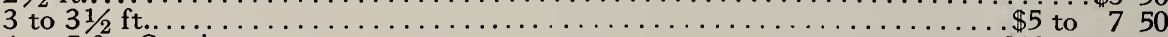

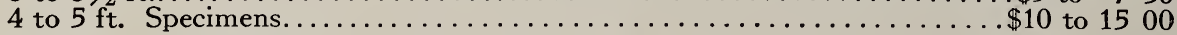

\section{Ram's-Horn Yew}

Taxus baccata, var. gracilis pendula

Also of perfect hardiness, one of the best Yews.

Each

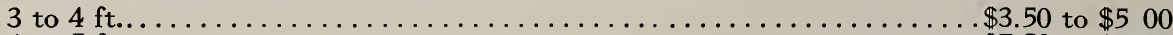

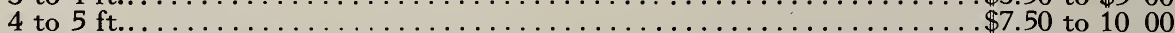

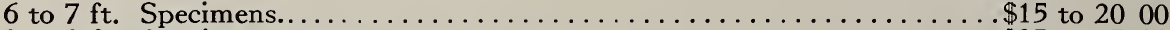

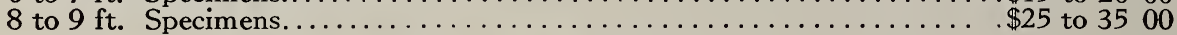

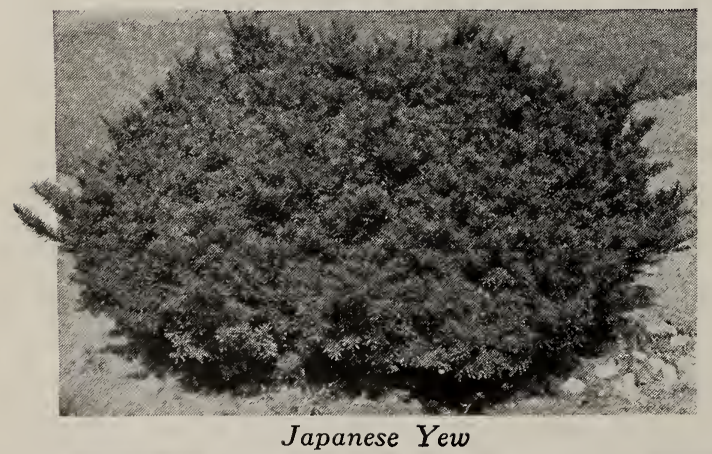

Japanese Yew
Clustered Japanese Yew

\section{Taxus cuspidata, var. capitata}

Distinctly Japanese in effect; of free-growing, open habit; with warm green needles; a tree of the highest merit, and of great hardiness, standing New England climate in almost any soil or situation.

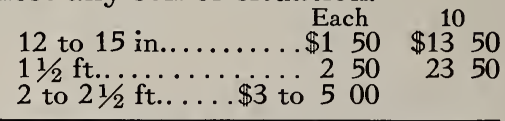




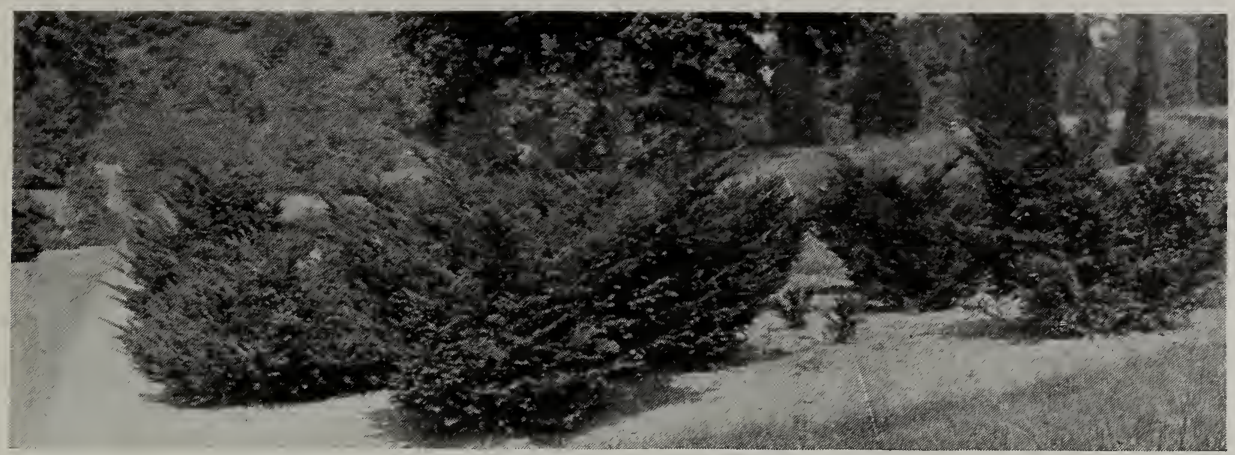

Japanese Yew

Japanese Yew

Taxus cuspidata

Combining the recommendations of absolute hardiness, rich dark green color, and adaptability to a wide variety of soils, the Japanese Yew is one of the most valuable plants. Its natural habit of growth is that of a rather open-branched free-growing bush attaining in years a height of 10 feet or more and of greater breadth. In early fall bright red berries appear prettily clustered in the dark green foliage. We recommend its use in groups or as specimen plants in formal locations, when it may be clipped. It is also most effective in combination with other Evergreens.

Each 10

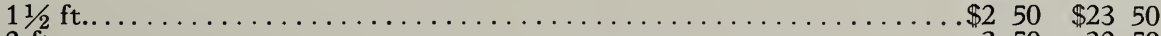

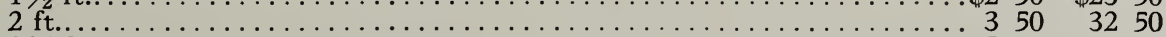

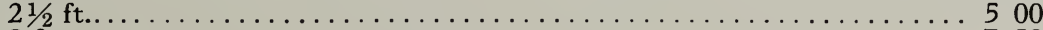

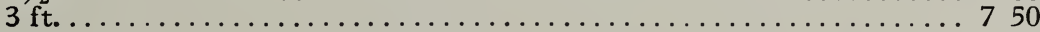

Small-leaved Hemlock

Tsuga canadensis, var. gracilis

A slender, graceful form of American Hemlock and much smaller.

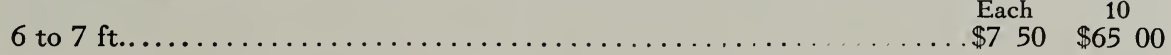

\section{Sargent's Weeping Hemlock}

Tsuga canadensis, var. Sargentii pendula Makes a low, broad, small tree with weeping branches.

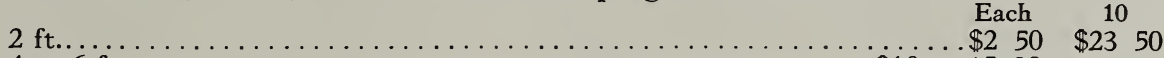

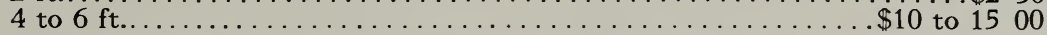

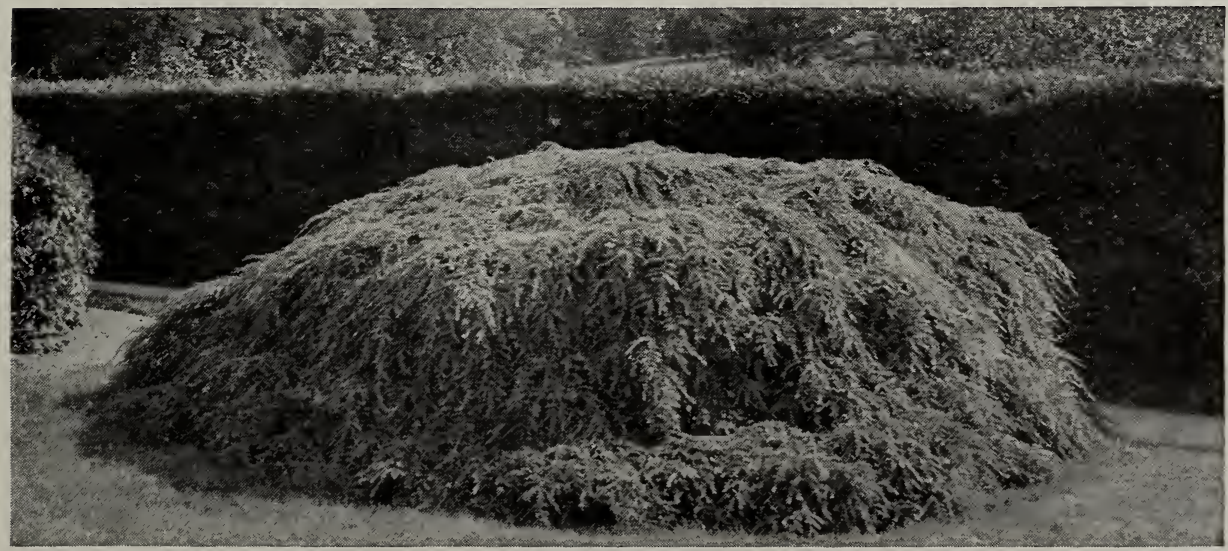

Sargent's Weeping Hemlock. In the background is a fine example of a tbick Norway Spruce bedge NO CHARGE FOR PACKING 


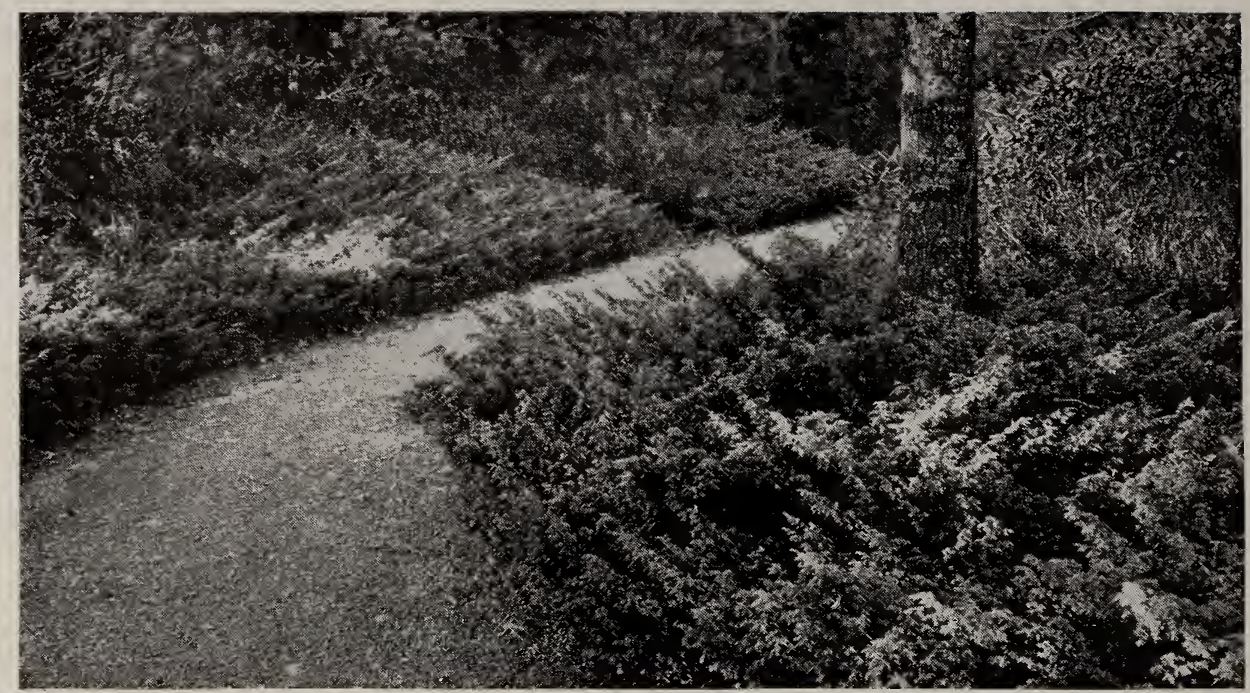

Group of Savins, producing a very naturalesque effect at the base of taller planting

\section{LOW-GROWING AND SPREADING PLANTS}

\section{Junipers}

Juniperus

These plants, better than any others, endure the trying conditions of sandy soil and drought and so are unusually adapted to planting in rocky places. Many an outcrop of ledge has been blasted away at great expense and an unsatisfactory lawn on shallow soil created when the natural ledge might have been made a thing of beauty and a pretty feature of the place if there had been planted in soilpockets some of the following varieties, together with Cedars and such flowering rock-plants as Columbine and Stonecrop.

\section{Canadian Juniper}

Juniperus canadensis

Silvery tinted green foliage; very close and spreading. For ground-cover or rock-planting.

12 to 15 in. spread.

Each

15 to 18 in. spread.

$\$ 100$

10

18 to 24 in. spread.

150

$\$ 900$

1250

1750

\section{Douglas' Golden Juniper}

\section{Juniperus canadensis, var. aurea; syn., Douglasii}

Bronzy yellow in winter; the new growth in spring is a bright golden green.

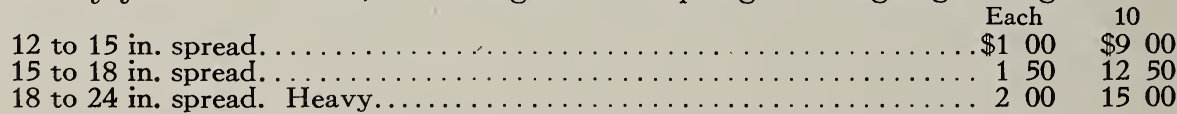

\section{Purple-tinted Juniper}

Juniperus canadensis, var. plumosa

Early in the fall a rosy shade of purple appears, becoming a deeper shade as cold weather increases; a very interesting color against the gray of rocks.

15 in

Each

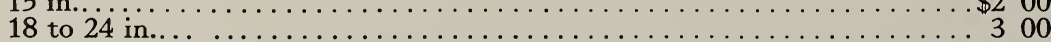

10

$\$ 1850$

2500

Dwarf Chinese Juniper

Juniperus chinensis, var. virginalis

Very dwarf; an unusual, interesting, little plant, desirable for park work.

$1 \mathrm{ft}$. . . . 


\section{Ground Savin}

\section{Juniperus sabina}

Most picturesque in its growth, especially on hillsides or among rocks; like a prostrate shrub in habit, and useful for all low plantings. The foliage is deep green and unchanging in its color.

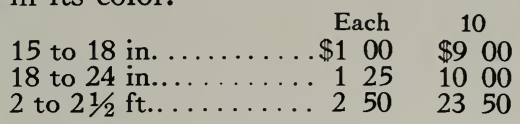

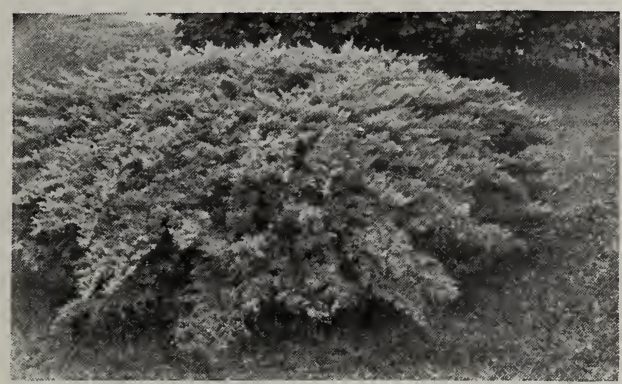

Tamarisk-leaved Savin

\section{Tamarisk-leaved Savin}

Juniperus sabina, var. tamariscifolia

Its gray-green, clean-looking foliage and very prostrate growth are attractive alike in summer and winter. May well be used as a low plant for the front of Evergreen borders.

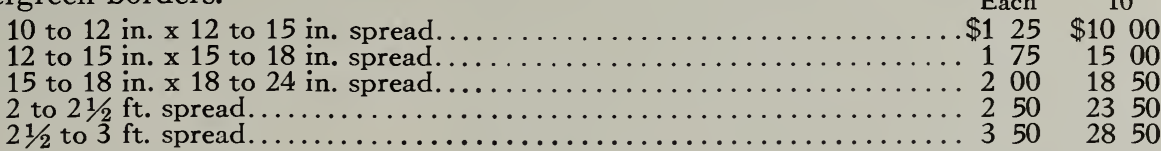

Japanese Trailing Juniper

Juniperus recurva, var. squamata

One of the most attractive of the low-growing Junipers, with its long, trailing branches covered with numerous short branchlets of glaucous green foliage; admirably adapted for naturalesque rock planting.
8 to 10 in. $x 12$ Each 10 to 15 in. spread ..\$1 $50 \$ 1250$
8 to 10 in. $x 15$ to 18
in. spread ....... $175 \quad 1650$
12 to 15 in. $x 18$ to
24 in..........2 200
15 to 18 in. $x 36$ to
48 in. Specimens. $350 \quad 3250$

\section{Spreading Virginia Cedar}

Juniperus virginiana, var. Kosteri

A very pretty spreading plant with foliage nearly like the Red Cedar.

2 to $21 / 2 \mathrm{ft} . \times 2$ to $21 / 2$
2 to $2 \frac{1}{2} \mathrm{ft} . \times 3$ to $31 / 2$

50

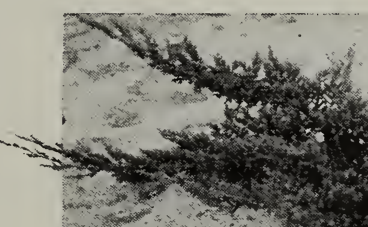

Low Japanese Juniper

Rich green foliage; attractive low-growing plant for Evergreen borders.

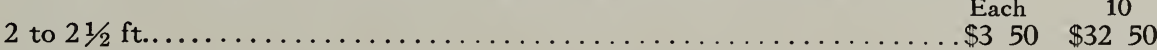

Japanese Trailing Juniper

$\begin{array}{rrrr}\text { Each } & 10 & 10 \\ \$ 2 & 50 & \$ 22 & 50 \\ 3 & 00 & 28 & 50\end{array}$




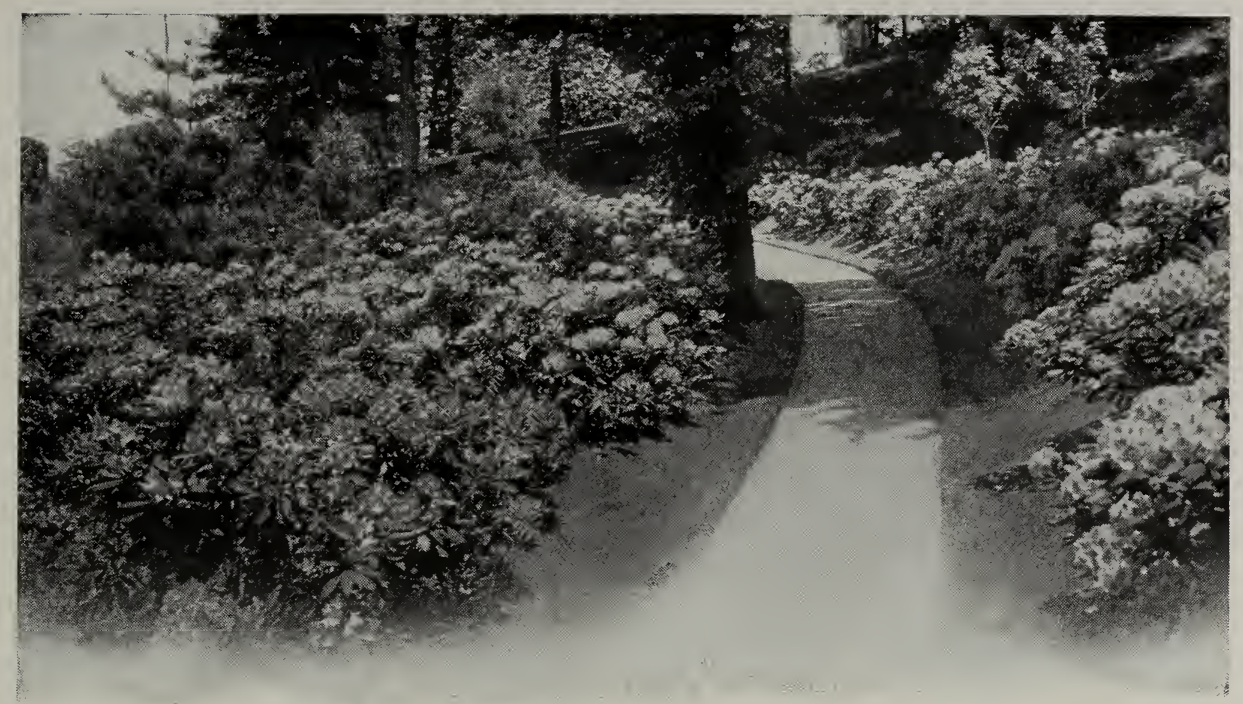

\section{Flowering Broad-leaved Evergreens}

W

THEN we stop to consider that "winter" in the North really means about five-twelfths of the year, the value of these plants with the mystic charm of their broad, lustrous leaves to relieve the bleakness and monotony of our grounds during this season is borne in upon us. Coupled with this aspect, we must also remember that the flowering varieties of this class of plants, like the Rhododendrons and Azaleas, produce the most gorgeous and sumptuous effects in spring and early summer months; while others, like the Japanese Holly, Euonymus and Evergreen Thorns, are equally valuable in the fall and winter for their showy berries. Then, too, these plants form pleasing combinations with other early spring-blooming plants which flower before the leaves are fully developed, as the Flowering Dogwood, Red-Bud, Magnolias, Azaleas, Japanese Witch Hazel, and many others.

In the planting of the Broad-leaved Evergreens a wide range of effects may be produced. The lovely Japanese Evergreen Azalea (Azalea amœna), its delicate spreading branches covered in early spring with deep claretcolored blossoms, brightens the shady woods' walk or is just as welcome at the front of high shrubbery or in masses against groups of tall Evergreen trees. Combinations of these flowering Evergreens with Evergreens of upright habit are always pleasing, for their irregularity of form relieves any appearance of stiffness and serves to bind a planting together into pleasing unity.

For many years we have paid especial attention to the growing of this class of plants and the stock which we offer represents the most meritorious sorts for American conditions; the plants have especially welldeveloped root-systems and the tops are exceptionally wide and spreading in proportion to the height. 


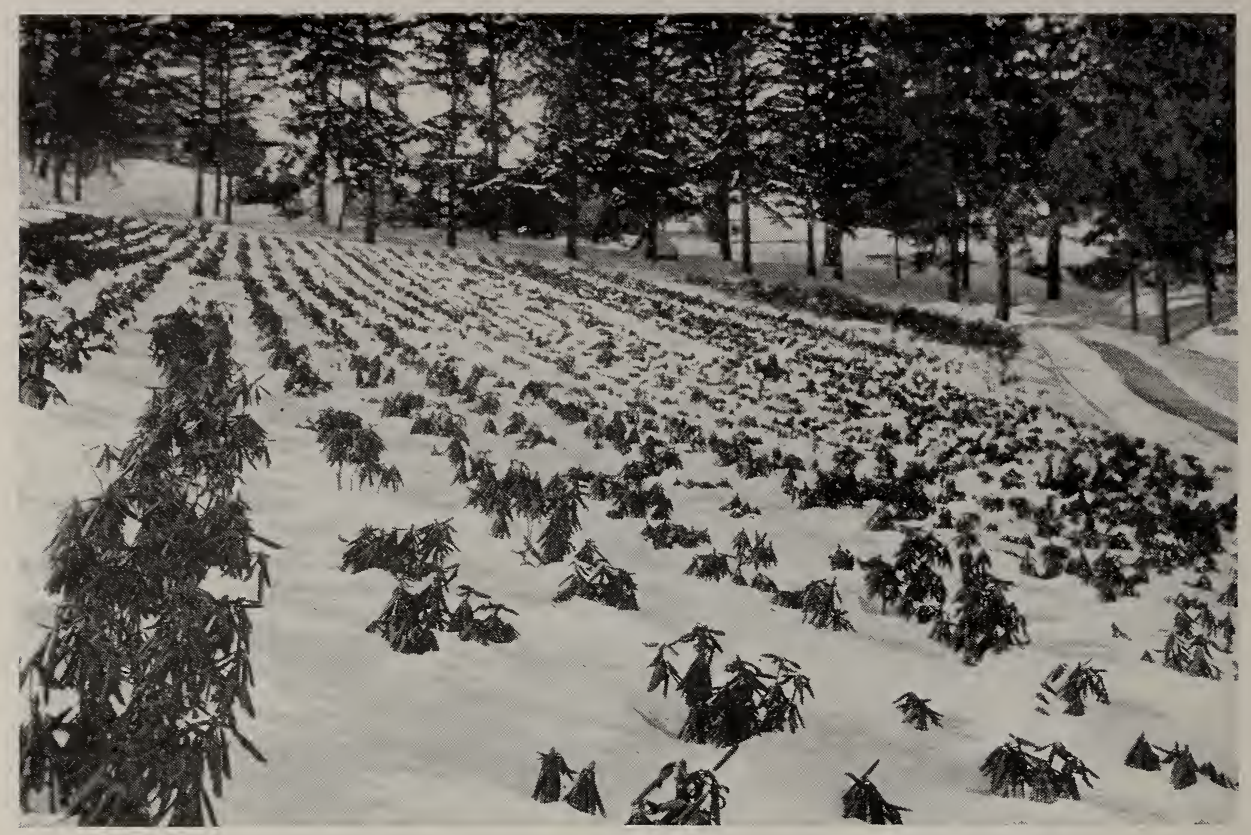

Field of Rbododendrons wintering in the ice and snow at Andorra

\section{Hybrid Rhododendrons}

In the buying of these plants, perhaps more than any others, the unwary purchaser is liable to encounter the pitfall of freshly imported plants which in a very favorable season may compare with American-grown stock. In these foreign-grown plants the death-rate will be high for four or five years, completely offsetting any seeming economy there may have been in their first cost, and they will be a source of constant dissatisfaction and expense. Our plants are grown here at Andorra for the American climate, and are broad, vigorous, acclimated plants, well-budded, lifting with a wonderful ball of fibrous roots.

We have catalogued our stock of over 30,000 plants in the following list in groups of colors, according to pages 44,45 , and 46 , as an aid to you in devising pleasing color combinations. We especially call your attention to the large sizes offered, which when planted with the smaller ones, relieve the appearance of flatness and monotony so frequently distastefuI in beds of Rhododendrons. To overcome the objection sometimes raised against the garish colors of some of the old sorts, we have made a discriminating choice of colors that are clear and bright and free from the objectionable magenta shades displeasing to some.

Rhododendrons will not grow happily in a limestone soil and if this condition exists it must be rectified by the use of peat or leaf-mold. A heavy mulch of leaves should be used to cover the beds and remain there permanently, adding another coating each fall; this keeps the roots cool and moist and supplies the needed humic acid. In exposed situations in winter a windbreak of some simple sort should be erected to break the full force of inclement winds. 


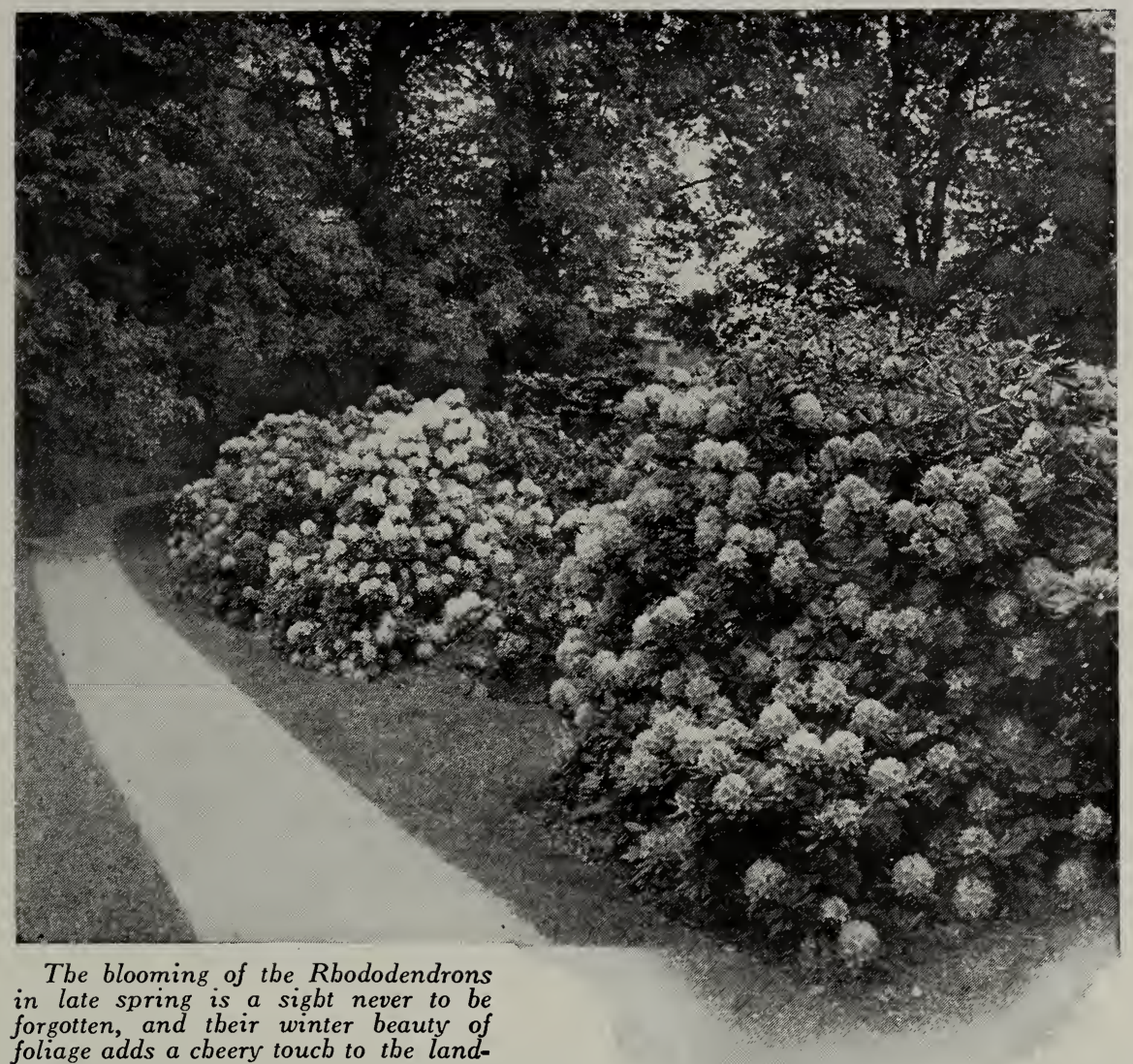

foliage adds a cheery touch to the landscape.

\section{The Culture of Rhododendrons}

Growing under natural conditions in the mountains, our native Rhododendrons thrive in an atmosphere of cool forest-fresh air surcharged with moisture; and in the British Isles, where the hybrid varieties display their gorgeous colors most sumptuously, we find again a climate that is prevailingly moist and where the nights are usually cool. If we would attain the greatest success with these wonderful plants, than which nothing is more beautiful in blossom, and which during all the seasons of the year possess an infinite charm of rich green foliage, we should bear the following points in mind:

Rhododendrons thrive best in masses, the shade and protection of each plant benefiting the others. The groups should be arranged so as to have natural or artificial protection from the prevailing inclement winds of winter and early spring. Most essential of all, remembering that the Rhododendron is a surface-rooted plant, keep the surface of the ground under the plants thickly mulched with rotted leaves or forest mold to sufficient depth to keep the ground still cool and moist during the hottest summer weather. Give the beds thorough preparation by trenching and by the addition of well-rotted cow manure and leaf-mold, and plant our acclimated American-grown plants. 
HYBRID RHODODENDRONS, continued

Album.

2 to $21 / 2 \mathrm{ft} . \ldots \ldots \ldots \ldots \$ 250$

3 to $5 \mathrm{ft} \ldots \ldots \ldots \ldots \$$ to 1250

Boule de Neige.

15 to 18 in........... 175

20 to 24 in.............. 250

Catawbiense, var. alba.

$11 / 2$ to $2 \mathrm{ft} . . \ldots \ldots \ldots \ldots 150$

$2 \mathrm{ft} . \ldots \ldots \ldots \ldots \ldots \ldots 200$

Luciferum.

$2 \mathrm{ft} \ldots \ldots \ldots \ldots \ldots \ldots$

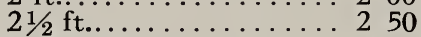

Mad. Carvalho.

$2 \mathrm{ft} . \ldots \ldots \ldots \ldots \ldots \ldots 200$

3 to $4 \mathrm{ft} \ldots \ldots \ldots \ldots . \$ 5$ to 750

Mad. Masson.

$11 / 2$ to $2 \mathrm{ft} . \ldots \ldots \ldots \ldots 225 \quad 2000$

$21 / 2 \mathrm{ft} . \ldots \ldots \ldots \ldots \ldots . \ldots 350 \quad 3350$

Mrs. John Clutton.

$11 / 2 \mathrm{ft} \ldots \ldots \ldots \ldots \ldots \ldots \ldots 150 \quad 1350$

$2 \mathrm{ft} \ldots \ldots \ldots \ldots \ldots \ldots 2 \quad 200 \quad 18 \quad 50$

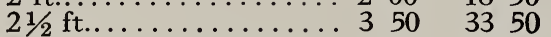

\section{BLUSH}

Album elegans. Blush-white.

$11 / 2$ to $2 \mathrm{ft} . \ldots \ldots \ldots \ldots 175 \quad 1500$

2 to $21 / 2 \mathrm{ft} \ldots \ldots \ldots \ldots \ldots \ldots \ldots \ldots \ldots 225$

$21 / 2$ to $3 \mathrm{ft} . \ldots \ldots \ldots \ldots . .350$

$31 / 2 \mathrm{ft}$. Specimens...... 500

2000

3250

4500

4- to 5-ft. specimens can be supplied in limited quantity.

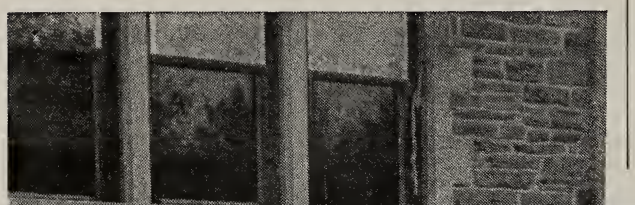

Album grandiflorum. Blush-white.

2 to $21 / 2 \mathrm{ft} \ldots \ldots \ldots \ldots \ldots 225 \quad \$ 2000$

$2 \frac{1}{2}$ to $3 \frac{1}{2} \mathrm{ft} . \ldots \ldots \$ 3$ to 500

Candidissimum.

$11 / 2 \mathrm{ft} . \ldots \ldots \ldots \ldots \ldots 175 \quad 1500$

$2 \mathrm{ft} . \ldots \ldots \ldots \ldots \ldots \ldots 2001750$

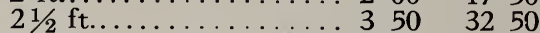

$3 \mathrm{ft} . \ldots \ldots \ldots \ldots \ldots 5$ to 750

Delicatissimum.

$11 / 2 \mathrm{ft} . \ldots \ldots \ldots \ldots \ldots 175 \quad 1500$

$2 \mathrm{ft} . \ldots \ldots \ldots \ldots \ldots \ldots 225 \quad 2000$

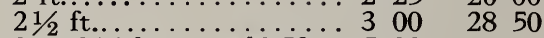

3 to $31 / 2 \mathrm{ft} . \ldots \ldots \$ 3.50$ to 500

Lady Gray Egerton. Blush-white.

$2 \mathrm{ft} . \ldots \ldots \ldots \ldots \ldots \ldots 250 \quad 2350$

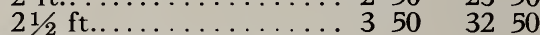

Parsons' gloriosum. Blush.

$\begin{array}{llllll}2 \mathrm{ft} . \ldots \ldots \ldots \ldots \ldots \ldots \ldots & 1 & 50 & 13 & 50 \\ 211 / 2 \mathrm{ft} . \ldots \ldots \ldots \ldots \ldots \ldots & 2 & 50 & 23 & 50\end{array}$

3 to $5 \mathrm{ft}$.........\$5 to 1000

\section{PINK}

Amphion. Rose-pink.

$11 / 2 \mathrm{ft} . \ldots \ldots \ldots \ldots \ldots . \ldots 250 \quad 2350$

$2 \mathrm{ft} . \ldots \ldots \ldots \ldots \ldots \ldots . \ldots . \ldots 350$

Ignatius Sargent. Deep pink. 15 to 18 in.............2 $200 \quad 1850$

$2 \mathrm{ft} . \ldots \ldots \ldots \ldots \ldots \ldots 250 \quad 2350$

Roseum elegans. (True.) Clear pink.

$11 / 2 \mathrm{ft} \ldots \ldots \ldots \ldots \ldots \ldots 200 \quad 1850$

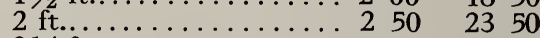

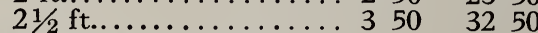

Roseum luteum. Pink.

$\begin{array}{lllll}2 \mathrm{ft} . \ldots \ldots \ldots \ldots \ldots \ldots & 2 \ldots & 50 & 23 & 50 \\ 21 / 2 \mathrm{ft} . \ldots \ldots \ldots \ldots \ldots & 50 & 33 & 50\end{array}$

Parsons' grandiflorum rubrum. Deep pink.

$11 / 2 \mathrm{ft} . \ldots \ldots \ldots \ldots \ldots, 150 \quad 1350$

$2 \mathrm{ft} . \ldots \ldots \ldots \ldots \ldots \ldots \ldots 2 \quad 00 \quad 1850$

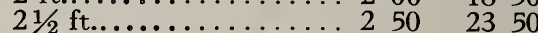

3 to $31 / 2 \mathrm{ft} . \ldots \ldots \ldots \$$ to 1000

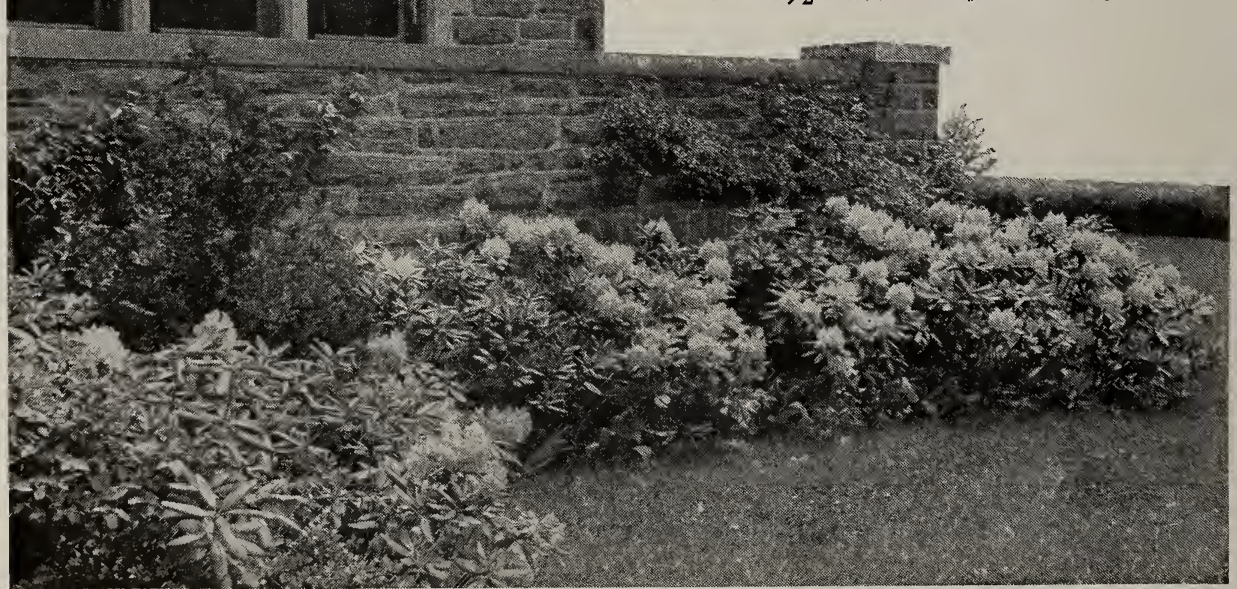

An effective planting of Rbododendrons and other Evergreens about the base of the bouse 


\section{HYBRID RHODODENDRONS, continued}

\section{CRIMSON}

Abraham Lincoln. Rosy crimson.

$11 / 2$ to $2 \mathrm{ft} . . \ldots \ldots \ldots \ldots \$ 175$ 2 to $21 / 2$ ft................ 25

$21 / 2$ to $3 \mathrm{ft} . \ldots \ldots \ldots 3.50$ to 500

Blandyanum. Rosy crimson.

$2 \mathrm{ft} . \ldots \ldots \ldots \ldots \ldots 225$

$21 / 2$ to $3 \mathrm{ft} . \ldots \ldots \ldots 3.50$ to 750

$31 / 2$ to $4 \mathrm{ft}$. Specimens.

$\$ 10$ to 1500

C. S. Sargent. Crimson.

24 in.............. 250

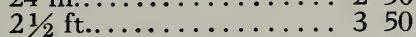

Daisy Rand. Deep crimson.

$$
11 / 2 \mathrm{ft} . \ldots \ldots \ldots \ldots \ldots 250
$$

F. D. Godman. Crimson.

$2 \mathrm{ft} . \ldots \ldots \ldots \ldots \ldots 250$

$21 / 2$ to $3 \mathrm{ft} . . . \ldots \ldots . . \$ 3.50$ to 500

Giganteum. Rosy crimson.

$11 / 2 \mathrm{ft} . \ldots \ldots \ldots \ldots \ldots \ldots \ldots$.
$21 / 2 \mathrm{ft} . \ldots \ldots \ldots \ldots \ldots \ldots$

$3 \mathrm{ft} . \ldots \ldots \ldots \ldots \ldots \ldots \ldots \ldots . \ldots \ldots \ldots$

H.H. Hunnewell. Dark crimson.

18 in.............. 200

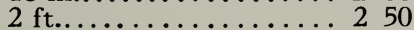

$21 / 2 \mathrm{ft} . \ldots \ldots \ldots \ldots \ldots \ldots . \ldots \ldots 35$

$3 \mathrm{ft} \ldots \ldots \ldots \ldots \ldots \ldots \ldots \ldots 750$

H. W. Sargent. Crimson.

$2 \mathrm{ft} . \ldots \ldots \ldots \ldots \ldots \ldots 250$

J.R. Trumpy. Rosy crimson. Each

$11 / 2 \mathrm{ft} . \ldots \ldots \ldots \ldots \ldots \ldots 250$

2850

10

$\$ 1500$

2000

2000

2350

3350

2350

2350

1500

2350

4750

1750

2350

3250

6000

2250

3250

Mrs. Milner. Crimson.

$2 \mathrm{ft} . \ldots \ldots \ldots \ldots \ldots \ldots 250 \quad 2350$

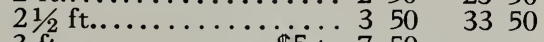

$3 \mathrm{ft} \ldots \ldots \ldots \ldots \ldots \ldots 5$ to 750

President Lincoln. Crimson.

$2 \mathrm{ft} . \ldots \ldots \ldots \ldots \ldots \ldots 250 \quad 2250$

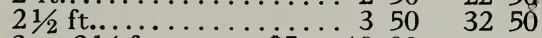

3 to $31 / 2 \mathrm{ft} \ldots \ldots \ldots \ldots \$ 5$ to 1000

SCARLET

Alex. Dancer. Light scarlet.

2 to $21 / 2 \mathrm{ft} . \ldots \ldots \ldots \ldots 350$

3250

Atrosanguineum. Dark scarlet.

18 to 24 in............2 $50 \quad 2350$

$21 / 2 \mathrm{ft} . \ldots \ldots \ldots \ldots \ldots \ldots . \ldots . \ldots 350 \quad 3250$

Charles Dickens. Scarlet.

$2 \mathrm{ft} \ldots \ldots \ldots \ldots \ldots \ldots 250 \quad 2350$

$21 \frac{2}{2}$ to $4 \mathrm{ft} . . . \ldots 33.50$ to 1000

Edward S. Rand. Rich scarlet.

$2 \mathrm{ft} . \ldots \ldots \ldots \ldots \ldots 250 \quad 2350$

General Grant. Rosy scarlet.

$2 \mathrm{ft} . \ldots \ldots \ldots \ldots \ldots \ldots 200 \quad 18 \quad 50$

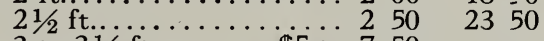

3 to $31 / 2 \mathrm{ft} . \ldots \ldots \ldots \ldots 5$ to 750

J. Marshall Brooks. Scarlet.

$2 \mathrm{ft} . \ldots \ldots \ldots \ldots \ldots 250 \quad 2350$

Lady Clermont. Rosy scarlet.

3250
3 to $3 \frac{1}{2} \mathrm{ft} . \ldots \ldots \ldots \$ 5$ to 750

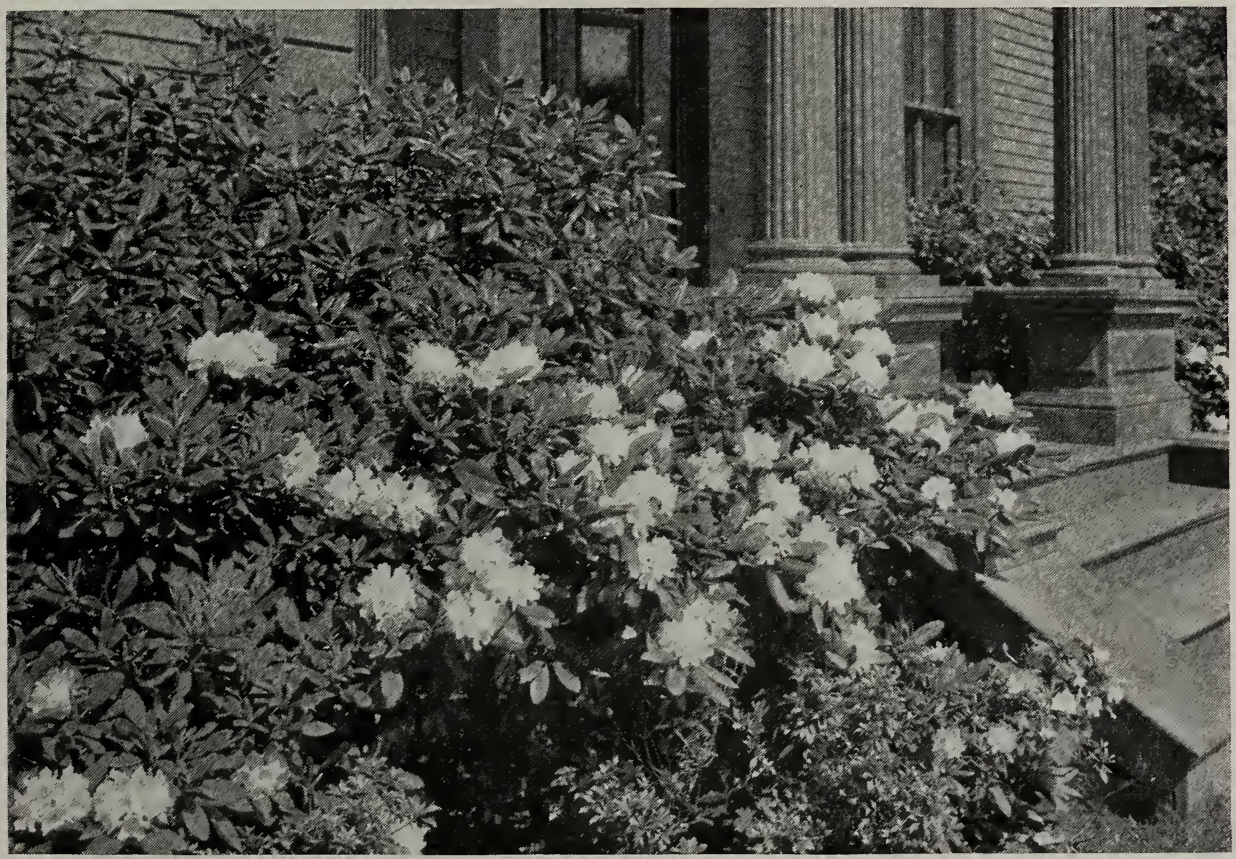

After the gorgeous blooms have faded, the mass of the rich green foliage of Rbododendrons through the rest of the year is always effective 


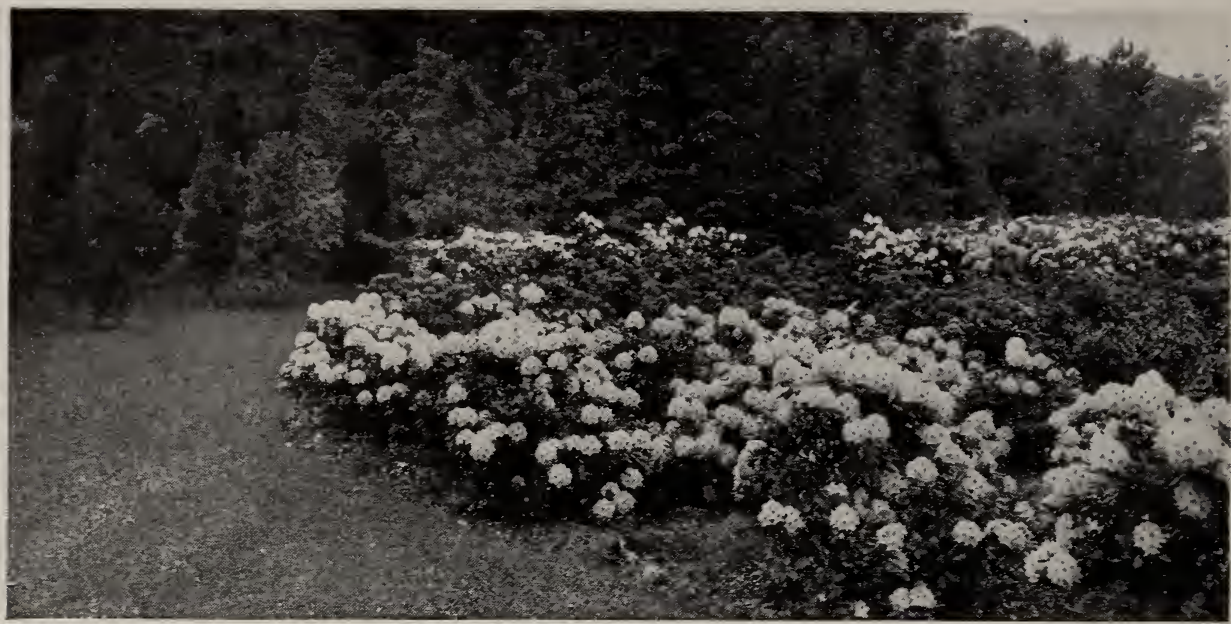

Rbododendrons may be massed at the edge of a wood witb cbarming effect, the long afternoon sbadows accentuating the myriad of sbades and tints

\section{HYBRID RHODODENDRONS, continued}

Anna Parsons. Red.

RED

2 to $21 \%$ Each

Charles Bagley. Bright red.

$11 / 2$ to $2 \mathrm{ft} . . \ldots \ldots \ldots \ldots 200$

$2 \mathrm{ft} \ldots \ldots \ldots \ldots \ldots \ldots \ldots \ldots 250$

$21 / 2$ to $3 \mathrm{ft} . \ldots \ldots \$ 3.50$ to 500

Hannah Felix. Light red.

$2 \mathrm{ft} . \ldots \ldots \ldots \ldots \ldots \ldots 250$

$21 / 2 \mathrm{ft} \ldots \ldots \ldots \ldots \ldots \ldots \ldots, 350$

Kettledrum. Deep red.

18 in.............. 250

24 in................... 350

$21 / 2$ to $3 \mathrm{ft} \ldots \ldots \ldots \ldots \$ 5$ to 750

Henry Probasco.

\section{CARMINE}

$11 / 2 \mathrm{ft} . \ldots \ldots \ldots \ldots 200$

\section{ROSE}

John Spencer. $2 \frac{1}{2} \mathrm{ft}$...... 300 3 to $41 / 2 \mathrm{ft} . \ldots \ldots \$ 5$ to 1000

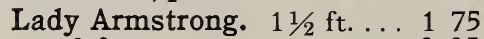

$2 \mathrm{ft} . \ldots \ldots \ldots \ldots \ldots \ldots 225$

$21 / 2 \mathrm{ft} . \ldots \ldots \ldots \ldots \ldots \ldots \ldots \ldots \ldots \ldots$

$3 \mathrm{ft} \ldots \ldots \ldots \ldots \ldots \$ 3$ to 750

Roseum elegans. $11 / 2 \mathrm{ft} . \ldots .150$ $2 \mathrm{ft} . \ldots \ldots \ldots \ldots \ldots \ldots 25$

$21 / 2 \mathrm{ft} \ldots \ldots \ldots \ldots \ldots \ldots$

3 to $5 \mathrm{ft}$. Spec.. $\$ 7.50$ to 2500

Roseum superbum. $2 \mathrm{ft} . \ldots .200$ $21 / 2 \mathrm{ft} . \ldots \ldots \ldots \ldots \ldots \ldots 350$ 3 to $4 \mathrm{ft} . \ldots \ldots \ldots \ldots \$ 5$ to 1000

\section{ROSE-LILAC}

Catawbiense. Each 10 $\begin{array}{rrrr}11 / 2 \text { to } 2 \mathrm{ft} \ldots \ldots \$ 1 & 50 & \$ 13 & 50 \\ 2 \mathrm{ft} . \ldots & & \end{array}$

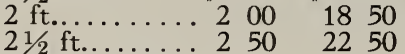

3 to $4 \mathrm{ft}$. Specimens.

$$
\$ 3.50 \text { to } 1000
$$

Everestianum.

15 to 18 in......... Each

18 to 20 in............... 200

20 to 24 in........... 250

$21 / 2 \mathrm{ft} . \ldots \ldots \ldots \ldots \ldots \ldots . \ldots \ldots$

3 to $31 / 2 \mathrm{ft}$. Heavy. $\$ 5$ to 1000

1750

2350

Mrs. H. Ingersoll. $11 / 2 \mathrm{ft} . \ldots 175$

$2 \mathrm{ft} . \ldots \ldots \ldots \ldots \ldots 250$

10

$\$ 1500$

1850

2250

3250

1650

2350

2350

3250

2350

3250

Herbert Parsons. Lilac. $2 \mathrm{ft} . \ldots \ldots \ldots \ldots \ldots \ldots 250 \quad 2350$

Kissena. Lavender. $11 / 2 \mathrm{ft} . \ldots \ldots \ldots \ldots \ldots 250$

\section{PURPLE}

Lee's. Dark purple. $2 \mathrm{ft}$. . $200 \quad 1850$ $2 \frac{1}{2} \mathrm{ft} . \ldots \ldots \ldots \ldots \ldots \ldots 250 \quad 2350$

Purpureum crispum. Purple crimped.
$11 / 2 \mathrm{ft} . \ldots \ldots \ldots \ldots \ldots \ldots$

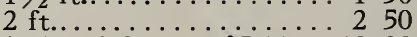
$21 / 2$ to $3 \mathrm{ft} . \ldots \$ 5.00$ to 1000
1350
2250

Purpureum elegans. Purple.
$2 \mathrm{ft} . \ldots \ldots \ldots \ldots \ldots 200$

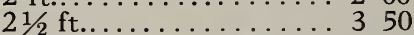
1850
3250

2000

2850

1350

2000

3250

1850

3250

Purpureum grandiflorum. Purple.

\section{ODD COLORS}

Caractacus. Purple-crimson.
$11 / 2 \mathrm{ft} . \ldots \ldots \ldots \ldots \ldots 175$

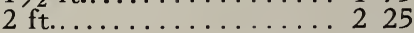
1500
2000

$2 \frac{1}{2}$ to $3 \mathrm{ft}$. Specimens..

$\$ 3.50$ to 750

Old Port. Plum. 15 to 18 in.. 150

$2 \mathrm{ft} . \ldots \ldots \ldots \ldots \ldots . \$ 35$ to 1000

$\$ 12500$

15000

20000

1350

2350

Sefton. Dark maroon.

$\begin{array}{llllll}11 / 2 \mathrm{ft} . \ldots \ldots \ldots \ldots \ldots & 2 & 00 & 18 & 50 \\ 2 & \mathrm{ft} \ldots \ldots \ldots & 2 & 50 & 23 & 50\end{array}$

$21 / 2 \mathrm{ft} \ldots \ldots \ldots \ldots \ldots \ldots . \ldots \ldots 30 \quad 3250$ 


\section{Catawban Rhododendron}

Rhododendron catawbiense

A native Rhododendron of the southern Alleghany Mountains, and the parentplant from which the many-hued hybrids listed on preceding pages were originated, and which they resemble in every detail of habit of growth. The color of the large trusses of bloom which it bears in late spring are a pleasing soft rose-lilac.

Where extensive plantings are contemplated, as in a wood, their variety serves as an admirable basework for the vari-colored hybrids; it also possesses the very valuable quality of great hardiness. For planting as far north as the New England States it cannot be too highly recommended. It is in every way a pleasing variety with which many are aII too unfamiliar.

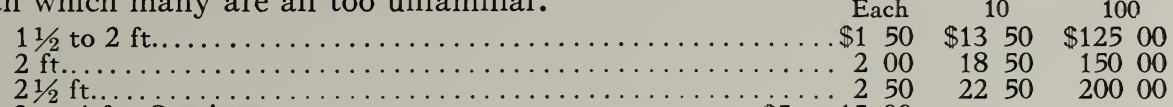

3 to $4 \mathrm{ft}$. Specimens............................ 1500

\section{Great Laurel}

Rhododendron maximum

Hardy as far north as Canada, this native of the Alleghanies is a valuable species for extensive plantings, through which some of the brighter and more profuse flowering sorts may be interspersed to great advantage. The flowers are rosy white to white in late June or July, and the leaves are large and rather long and narrow.

The plants offered below are clumps, which we have grown on firm collected plants in our Nurseries, and are superior to those freshly collected from the woods as they have established a good ball of frbrous roots which insures their success.

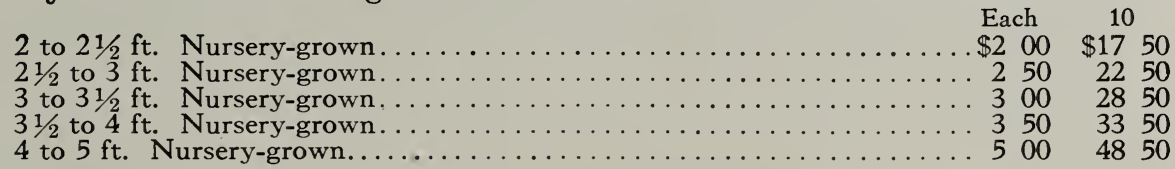

\section{Great Pink Laurel}

Rhododendron maximum, var. roseum

Flowers pink; very attractive.

Each 10

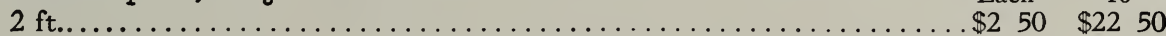

\section{COLLECTED PLANTS OF RHODODENDRON MAXIMUM}

Where very large plantings are contemplated, we can make attractive quotations for plants in carload lots, shipped direct from our collecting-frelds in the mountains, in sizes ranging from 2 to 6 feet in height. Prices upon application.

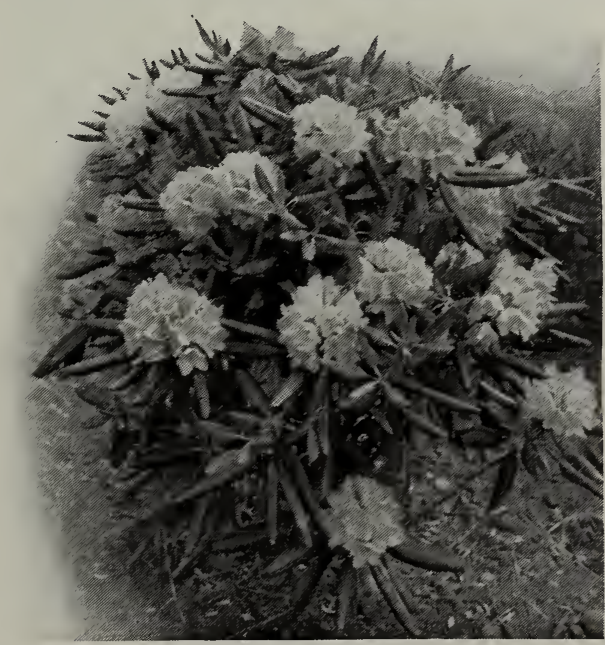

Rbododendron catawbiense

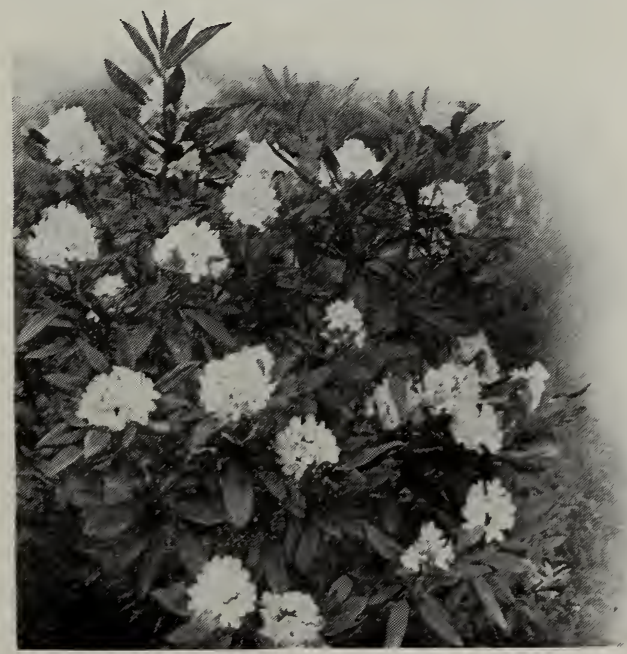

Rbododendron maximum

NO CHARGE FOR PACKING 


\section{Dwarf Rhododendrons, or Alpine Roses}

Growing eventually to a height of only a few feet, these charming slow-growing little plants are covered in May and June with a profusion of blossoms in delicate shades of pink, while the foliage of all these varieties is especially interesting in coloring in the winter.

These pretty-flowered plants are a much-prized addition to the rockery. In groups, combined with the Iarger species of Rhododendrons, Azaleas, or other Evergreens, they are most effective.

Rhodedendron hammondii. Blush-pink flowers; dark green leaves.

R. hirsutum. A pretty plant from the AIps; pink blooms in June and

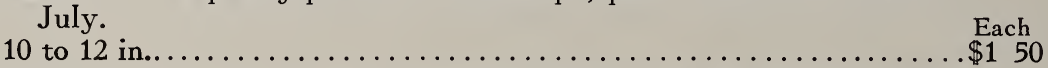

R. imbricatum. Fine for rock planting; small black-green leaves; violetpurple blooms.

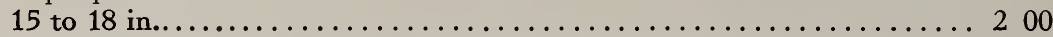

R. multiflorum. Low-growing, dense plant; very profuse pink bloom.

18 in............................................. 200

R. myrtifolium. Handsome, smaIl, myrtle-green foliage; pink flowers.

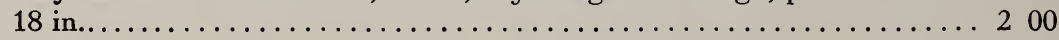

R. odoratum. Strong-growing but dwarf; an abundance of smaII, pink, fragrant flowers in June.

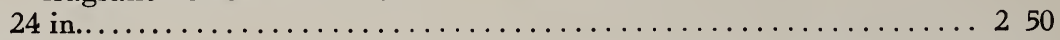

R. punctatum. Pale rose-colored flowers prettily dotted with green in the throats of the bloom; early bloomer; loose growing.

12 to 15 in........................................... $150 \quad 1350$

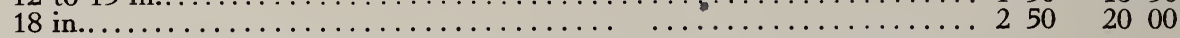

R. wilsonianum. Very dark pink flowers; low and bushy in habit.

12 to 15 in....................................... 150

15 to 18 in....

2350

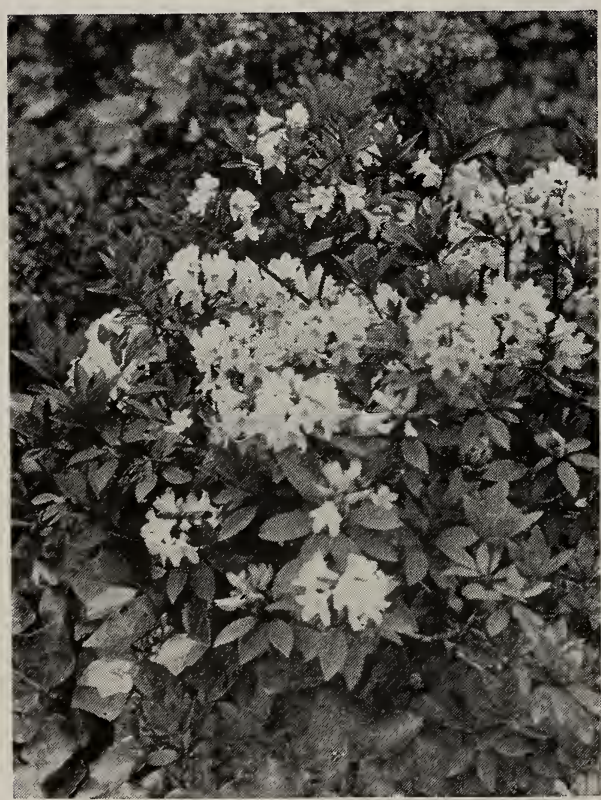

Dwarf Rbododendron, Alpine Rose

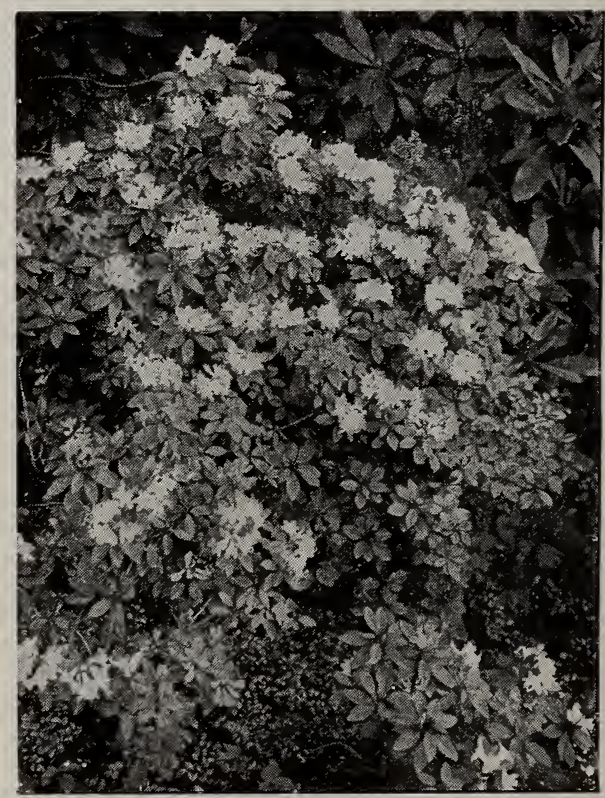

Rbododendron wilsonianum

A'NDORRA NURSERIES 


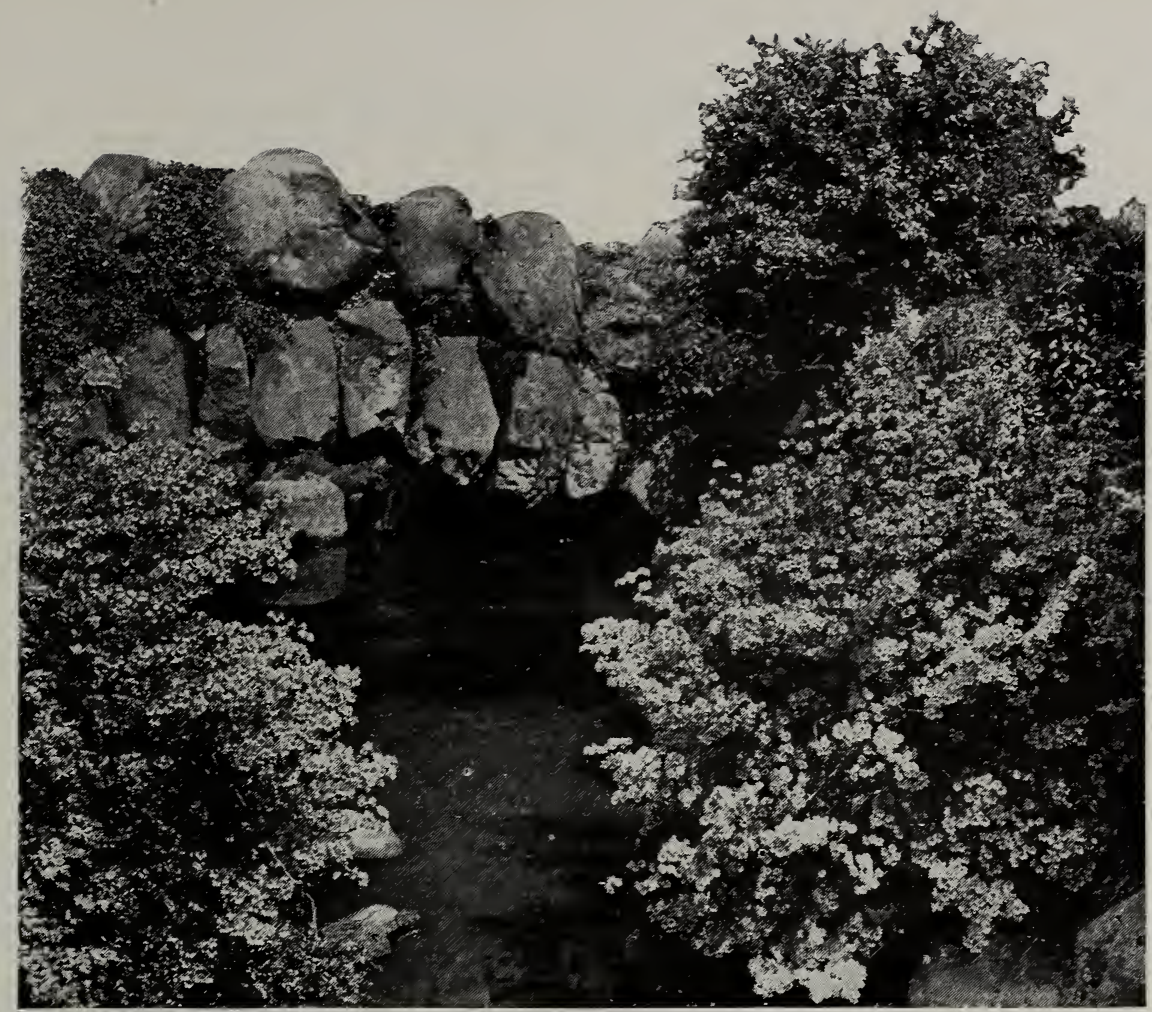

Azalea amona, and in fact all of these flowering Evergreens are particularly beautiful for naturalesque effects

\section{Evergreen Azaleas and Other Beautiful Flowering Evergreens}

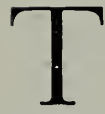

HE plants included in the following pages are all appropriate for arrangement on the borders of higher Evergreen plantings, about the base of the house or in the garden; all are conspicuous for their pretty flowers in the spring.

\section{Arbutus-flowered Shrub}

\section{Abelia rupestris (chinensis)}

Blooming continuously from June until nipped by the frost in the faII, this graceful shrub is covered with a mass of white flowers tinted with pink; in early winter its leaves, glossy green in summer, are tinged with coppery bronze. The hard winters in the North are liable to spoil its foliage effect after New Year's, and north of New York its hardiness would be questionable, but its exquisite charm makes it weIl worth a little extra care.

$$
\begin{aligned}
& \begin{array}{lll}
\text { Each } & 10 & 100
\end{array} \\
& 1 \mathrm{ft} . \ldots \ldots \ldots \ldots \ldots \ldots \ldots . \$ 0 \quad 50 \quad \$ 4 \quad 50 \quad \$ 3500 \\
& 2 \mathrm{ft} \ldots \ldots \ldots \ldots \ldots \ldots \ldots \ldots \ldots \ldots \ldots \ldots, 100 \quad 750 \quad 6000
\end{aligned}
$$

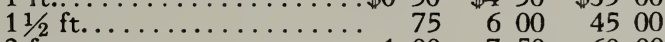

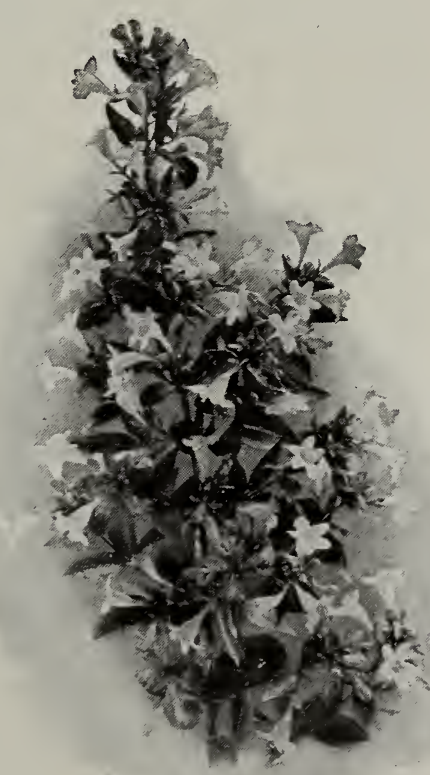

Abelia rupestris 


\section{Mountain Fetterbush}

Andromeda (Pieris) floribunda

Delicate clusters of greenish white buds, appearing in autumn, give this low, broad bush the appearance of being in bloom all winter, although the white blossoms do not appear until spring; very dark green foliage; slow-growing.

\begin{tabular}{|c|c|c|}
\hline 2 in. broad..\$1 50 & $\begin{array}{l}10 \\
\$ 1350\end{array}$ & 100 \\
\hline $\begin{array}{l}2 \text { to } 15 \mathrm{in} . \\
\text { broad.... } 175\end{array}$ & 1650 & $\$ 14000$ \\
\hline $\begin{array}{l}5 \text { to } 18 \text { in. } 200 \\
\text { broad.... } 200 \text {. }\end{array}$ & 1850 & 16500 \\
\hline $\begin{array}{l}8 \text { to } 20 \text { in. } \\
\text { broad.... } 275 \\
2 \text { to } 24 \text { in. }\end{array}$ & 2500 & 20000 \\
\hline broad..... 350 & 3250 & \\
\hline
\end{tabular}

\section{Japanese Fetterbush}

\section{Andromeda (Pieris) japonica}

Taller and more open in habit than the above. The young leaves in spring are ricil bronzy green, later becoming darker; flowers white, in graceful, nodding clusters. Both this plant and the above are admirably adapted to massing with Rhododendrons.

\begin{tabular}{|c|c|c|}
\hline Each & 10 & 100 \\
\hline $\begin{array}{l}12 \text { to } 15 \text { in....\$1 } 25 \\
15 \text { to } 18 \text { in.. } 150\end{array}$ & $\$ 1000$ & $\$ 1000$ \\
\hline 20 in.... 200 & 1850 & $\begin{array}{r}\$ 14500 \\
145\end{array}$ \\
\hline $\begin{array}{l}\text { to } 24 \text { in.... } 2550 \\
\text { to } 30 \text { in... } 350\end{array}$ & $\begin{array}{ll}22 & 50 \\
32 & 50\end{array}$ & \\
\hline
\end{tabular}

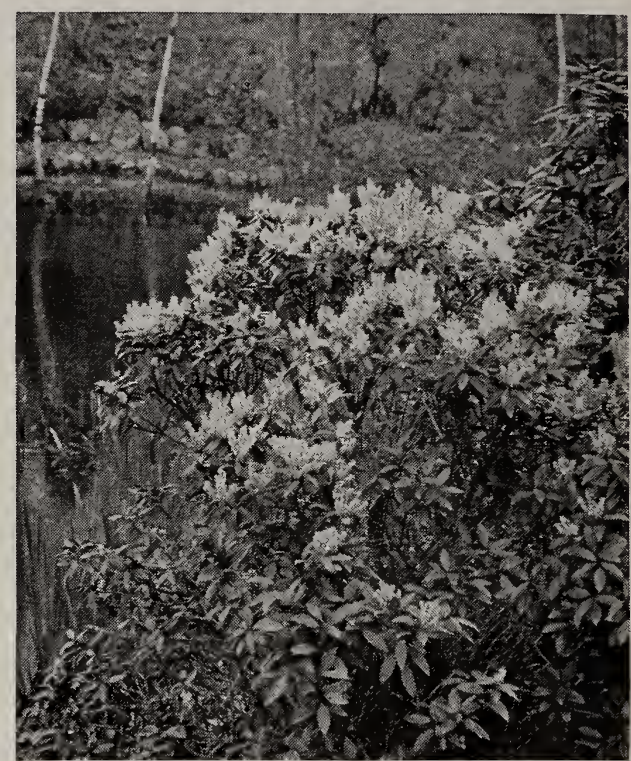

The Mountain Fetterbush adapts itself to a variety of situations

\section{Japanese Evergreen Azalea}

Azalea amœna

A spreading bush, covered in May with a mass of vivid claret-colored flowers which hide leaf and twig completely in their profusion. It lights up shady corners where a strong color effect is desired, but should not be associated closely with the following variety or with Rhododendrons, on account of the intensity of its coloring. Hardy to New York. A hillside of several acres in our nurseries covered with this Dlant in full bloom, against Hemlocks and Flowering Dogwoods, is a sight not soon

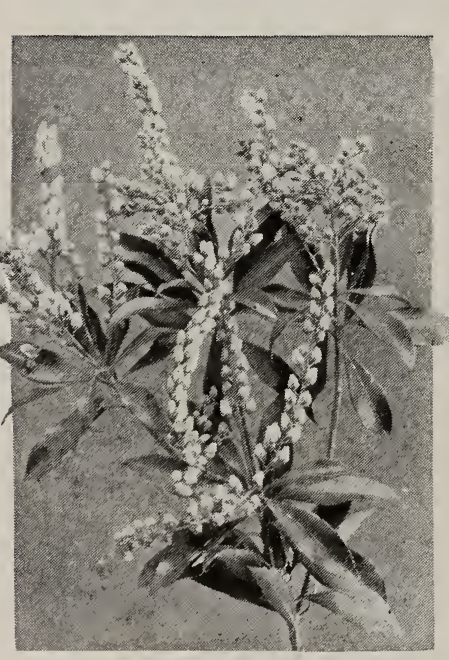

Spray of the Japanese Fetterbush

$$
\begin{aligned}
& \begin{array}{lll}
\text { forgotten. } \quad \text { Each } & 10 & 100
\end{array} \\
& 12 \text { to } 15 \text { in............\$1 } 00 \quad \$ 850 \quad \$ 7500 \\
& 15 \text { to } 18 \text { in. Bushy......... } 125 \quad 1150 \quad 9000 \\
& 11 / 2 \mathrm{ft} \text {. Bushy............ } 150 \quad 1350 \quad 12500 \\
& 2 \mathrm{ft} \text {. Bushy................ } 200 \quad 1850 \quad 16500 \\
& 2 \text { to } 2 \frac{1}{2} \mathrm{ft} \text {. Specimens. } \$ 3.50 \text { to } 500
\end{aligned}
$$

\section{Pink Japanese Evergreen Azalea}

\section{Azalea amœna, var. Hino-di-giri}

Individually beautiful blossoms of carmine-pink in the spring, absolutely covering this spreading bush, make this visitor from Japan a wonderful addition to evergreen plantings or gardens, while its richly tinged bronze-green foliage in winter is always attractive. To those who love strong, intensive coloring, this plant will especially appeal.

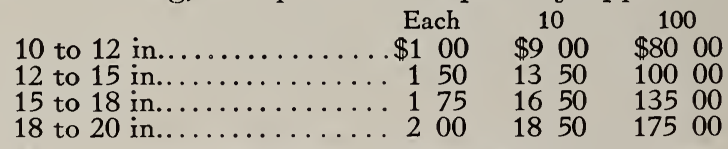


Hardy Indian Azalea

Azalea indica, var. album

In delicacy and profusion of bloom these dense-growing low shrubs vie with the tender sorts grown in greenhouses; they are one of our showiest, handsomest shrubs and should be in every garden. North of New York their hardiness is questionable and the deciduous Azaleas should be used instead.

12 in............. E1 $50 \quad \$ 1350$

$2 \mathrm{ft} \ldots \ldots \ldots \ldots \ldots \ldots \ldots 250 \quad 2350$

\section{Hardy White Azalea}

\section{Azalea ledifolia, var. leucanthum}

Slightly hardier than the above and one of the showiest of garden Azaleas. The flowers of purest white, 3 inches in diameter, completely hide the gray-green foliage.
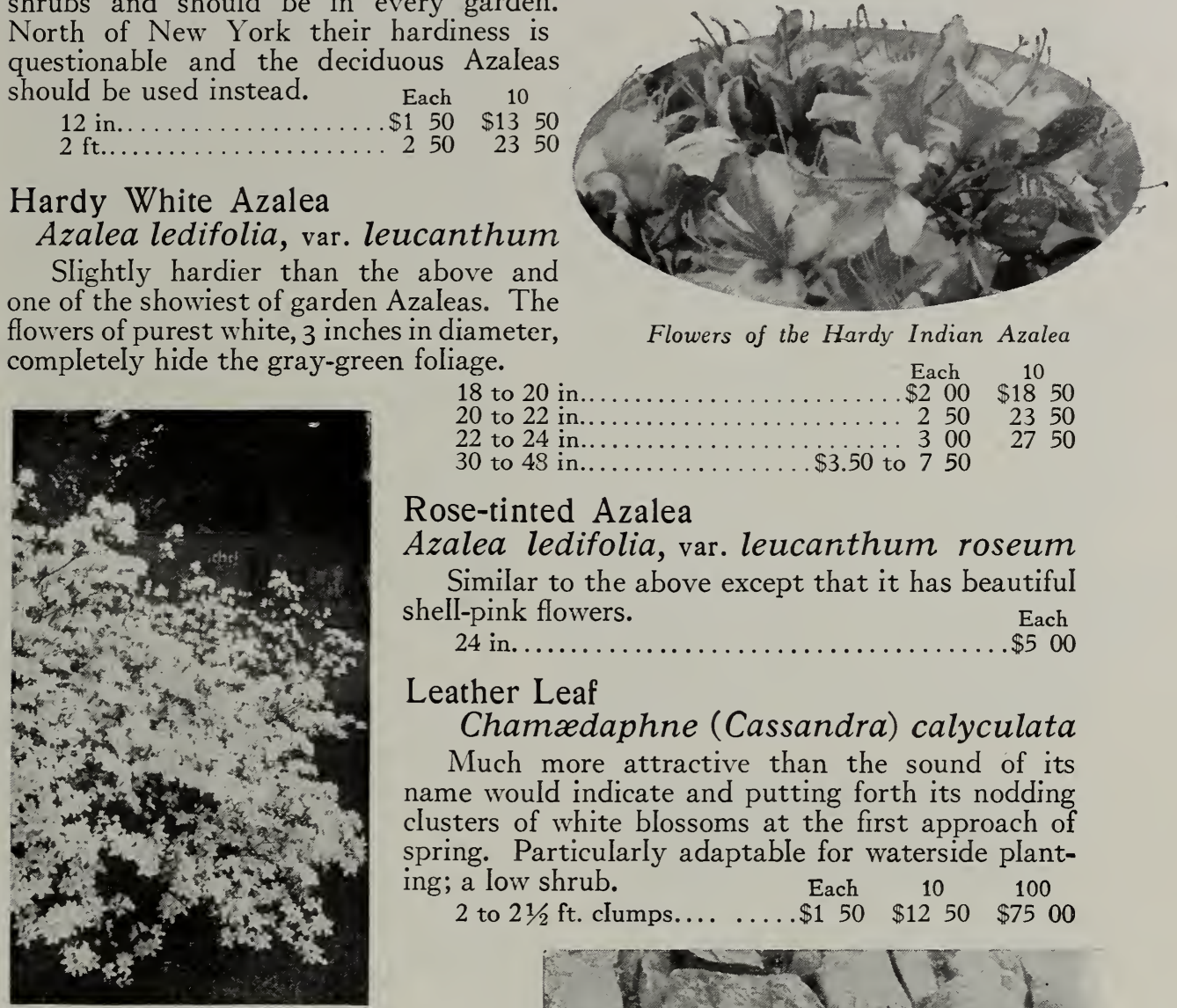

Flowers of the Hardy Indian Azalea

20 to 22 in................... 50 23 50

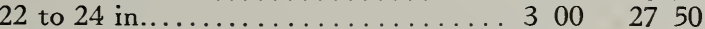

30 to 48 in.............\$3.50 to 750

Rose-tinted Azalea

Azalea ledifolia, var. leucanthum roseum

Similar to the above except that it has beautiful shell-pink flowers.

Each

24 in.....................\$5 00

\section{Leather Leaf}

Chamædaphne (Cassandra) calyculata

Much more attractive than the sound of its name would indicate and putting forth its nodding clusters of white blossoms at the first approach of spring. Particularly adaptable for waterside planting; a low shrub. Each $10 \quad 100$ 2 to $2 \frac{1}{2} \mathrm{ft}$. clumps.... .... $\$ 150 \quad \$ 1250 \quad \$ 7500$

Azalea ledifolia, var. leucantlsum

\section{Garland Flower}

\section{Daphne cneorum}

Its low, green stems rise but a few inches above the ground, each bearing as a crown or garland a cluster of tiny pink flowers of the most delicate fragrance, approaching that of orange blossoms. One of the daintiest little garden plants.

When naturalized in groups or colonies in the Evergreen border or rockery, it forms a solid mass of dark green foliage close to the ground, above which the pink flowers are borne in great profusion.

75 cts. each, $\$ 6$ for 10.

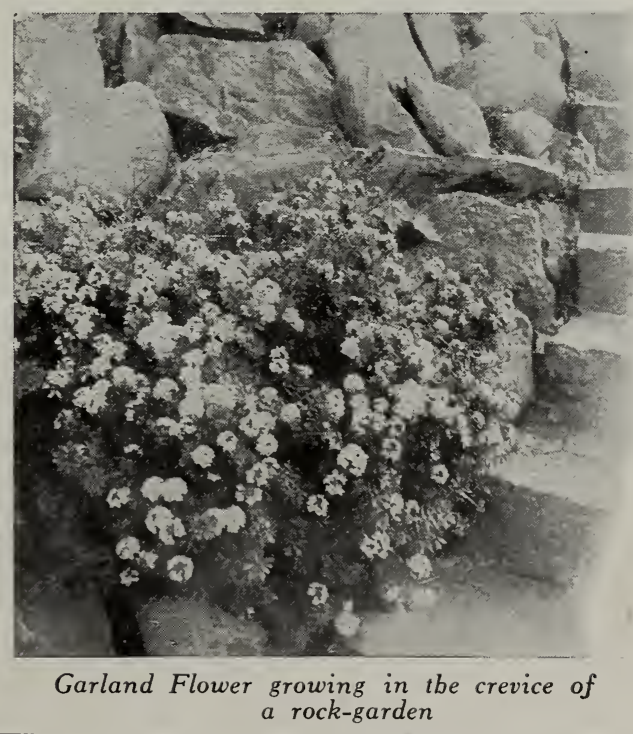

NO CHARGE FOR PACKING 


\section{Mountain Laurel}

\section{Kalmia latifolia}

In England this plant is grown in gardens and borders and is most highly prized for its showy masses of pink flowers in June and for its shiny dark green foliage and interesting habit of growth. When we see it there grown in such perfection it seems as if we had rather neglected it in this country as "one of those native plants." Nurserygrown plants, such as we offer, can be planted in the same way as Rhododendrons, with the same resulting effects of great beauty. Mountain Laurel will stand partial shade, but the flowers do not exhibit the same rich pink coloring as when grown in open sunlight. Light, rich, well-drained soils give the best results.

Each $10 \quad 100$

$11 / 2 \mathrm{ft}$. Clumps.. $\$ 150 \$ 1250 \$ 10000$

$2 \mathrm{ft}$. Clumps.... $200 \quad 18 \quad 50 \quad 17500$

$21 / 2 \mathrm{ft}$. Clumps.. $250 \quad 2250 \quad 20000$

$21 / 2 \mathrm{ft}$. Heavy

clumps..... $350 \quad 3000$

\section{Drooping Andromeda}

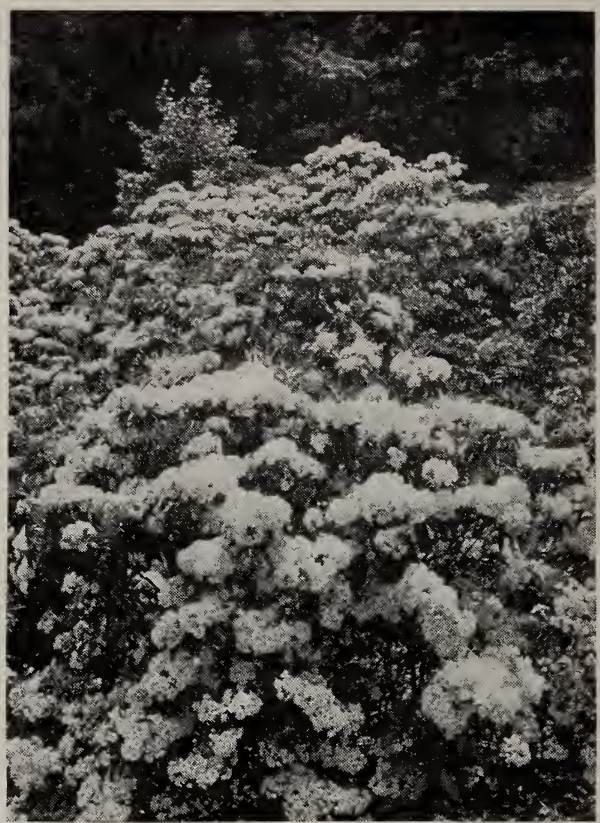

Mountain Laurel grouped at the edge of a wood

\section{Leucothoë catesbæi}

Its graceful, red-brown stems, arching a few feet above the ground, are covered

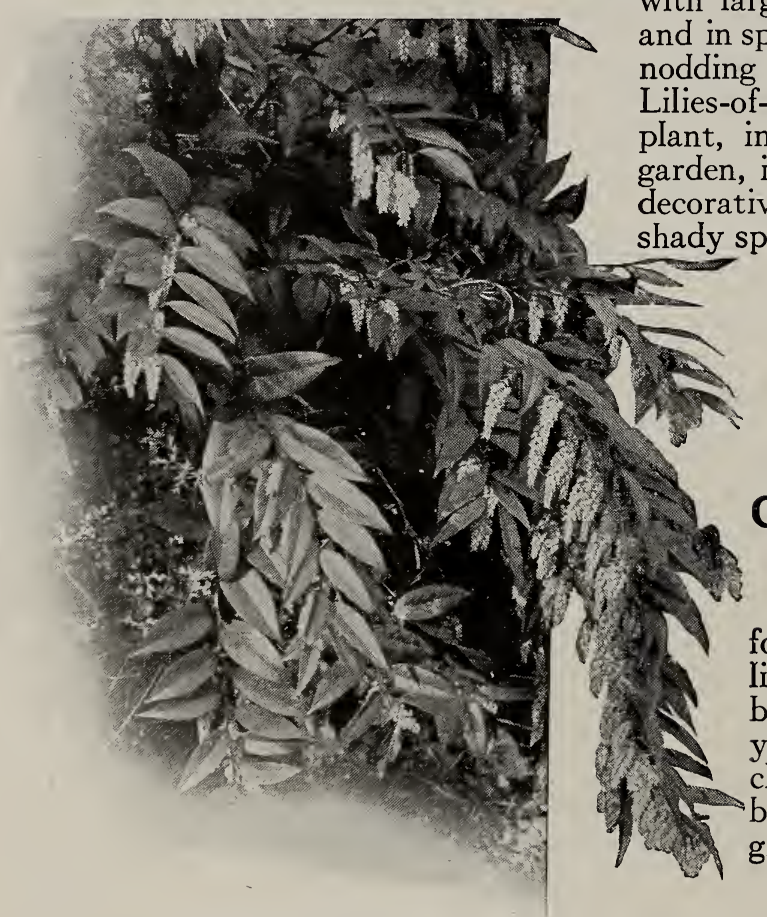

Drooping Andromeda

with large leaves of dark shining green, and in spring with cream-white flowers in nodding sprays, greatly resembling smaII Lilies-of-the-Valley. As a ground-covering plant, in partial shade, or in the wild garden, it is effective and is wonderfully decorative in an Evergreen border for shady spots.

12 to $15 \mathrm{in}$

Each $10 \quad 100$

Clumps.\$1 $00 \quad \$ 8 \quad 50 \quad \$ 6000$

15 to $18 \mathrm{in}$.

Clumps. $150 \quad 1250$

$2 \mathrm{ft}$. Extra-

he a vy

clumps.. $250 \quad 2250$

\section{Oregon Grape, or Mahonia \\ Mahonia aquifolium}

Both this plant and the one following have leaves very much like Holly, and in spring they bear great heads of small, rich yellow flowers, followed by showy clusters of blue-black berries like bunches of grapes. Both are lowgrowing and spreading.

\begin{tabular}{|c|c|}
\hline $\begin{array}{l}\text { Each } \\
15 \text { to } 18 \text { in. } \$ 075 \\
18 \text { to } 24 \text { in. } 100\end{array}$ & $\begin{array}{l}10 \\
\$ 500 \\
750\end{array}$ \\
\hline
\end{tabular}




\section{Japanese Mahonia}

\section{Mahonia japonica}

Like the preceding, this plant does best in the North if planted in a spot where the rays of the sun are partly broken.

Each

$11 / 2$ to $2 \mathrm{ft} \ldots \ldots \ldots \ldots \ldots \$ 150 \quad \$ 1250$

2 to $21 / 2 \mathrm{ft} . \ldots \ldots \ldots \ldots \ldots 200 \% 1850$

$21 / 2$ to $3 \mathrm{ft} . \ldots \ldots \ldots \ldots \ldots .300 \quad 2500$

\section{Evergreen Magnolia Magnolia grandiflora}

Those who have not seen this beautiful tree growing in the South or on the Pacific Coast can have only a slight appreciation of its charm through any worded description. It represents the epitome of richness in Evergreens, with its large, shining, dark green foliage, bronzed beneath, and great, beautiful, waxy white, fragrant flowers; and the Iater opening of the seed-cone showing the crimson seed is most attractive. Forms a tall, stately tree and is hardy as far north as Long Island, although it may require winter protection for a few years until the young trees are thoroughly established.

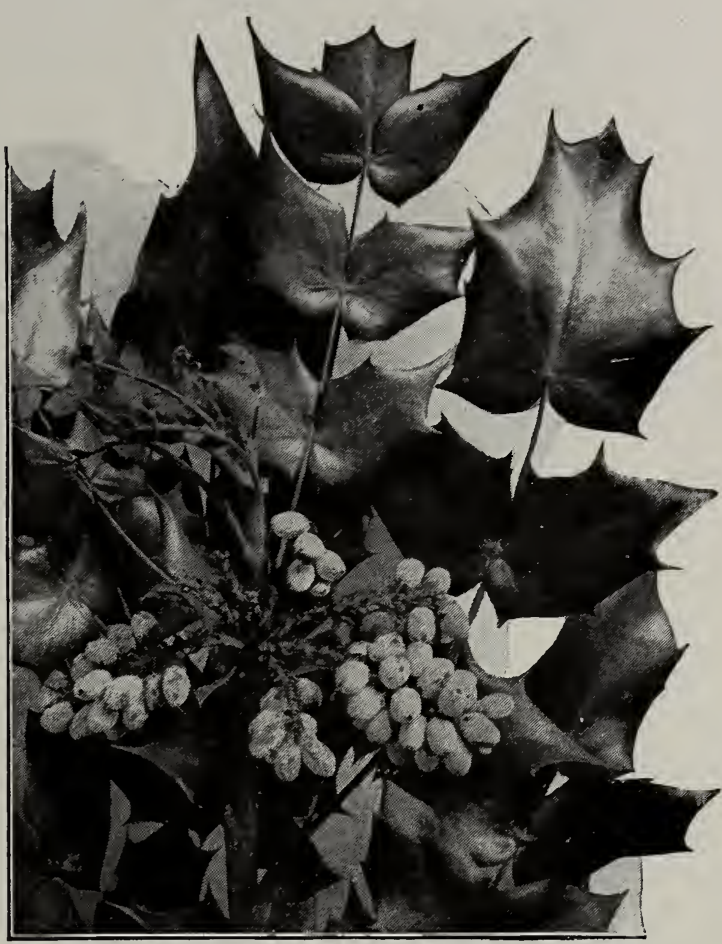

Mabonia, with its attractive blue berries

$$
\text { Each } 10
$$$$
\$ 3 \quad 50 \quad \$ 32 \quad 50
$$

\section{Adam's Needle}

\section{Yucca filamentosa}

The stately clusters of narrow, very pointed leaves a couple of feet high, frayed into tiny threads along the edges, are surmounted in summer by majestic

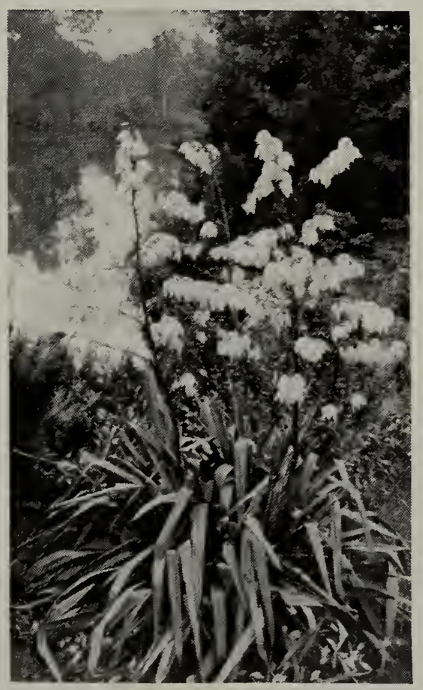

Adam's Needle stems 4 to 6 feet tall, bearing a profusion of creamy white flowers.

Each 10 Clumps....................\$0 $50 \$ 350$

\section{Evergreens in Woods Planting}

- The woodland walk and the borders of a wood where the deep shadows lie are susceptible of the most attractive colonization of Evergreens, as Mahonia, Mountain LaureI, Rhododendrons, and Azaleas, with here and there a clump of Garland Flower and a carpet of Periwinkle or Japanese Spurge under a spreading tree, through which may nod in early spring the gay Daffodil or prim Poet's Narcissus.

These, together with the many shade-loving shrubs and perennials, will make many a woodland corner a joy at all seasons, from the first warm days of spring which open up the Trilliums until the mid-winter months when the Holly berries show scarlet against the foliage of the surrounding Evergreens. 


\section{Large Trees for Specimens or Screens}

7 HROUGHOUT this catalog there are listed both Evergreens and Deciduous Trees in Iarger sizes than are usually obtainable from nurseries. From the time the tiny seeds leave the propagating beds, where they are carefully tended and watched, the growth of these trees has been dominated by one purpose, that of producing plants that are well developed both as to the top, or head, and especially as to the root-system. By frequent transplanting and root-pruning, careful training and trimming, these trees have been grown for many years with ample space for the development of their natural characteristics and habits. Thus we are enabled to offer beautiful specimens with great balls of fine, fibrous feeding-roots which can be successfully transplanted and which will produce immediate effects.

The two pompous old Box Bush in the illustration on page 29 are examples of some of our Andorra-grown specimens in large sizes.

To those who wish to plant stock commensurate with dignity and architectural character, harmonious and in scale with house or garden, we would invite a personal examination, if possible, of the many varieties of tall Japanese Cypress and Junipers, pleasing with the play of light and shadow on their fine-cut needles, Iarge Firs, and Spruce, and of the rare old specimens of Box Bush and Japanese Holly which have taken on the modeling and contour of maturity so thoroughly appropriate to Colonial architecture.

On our grounds are many Rhododendron plants in Iarge sizes, and spreading Azaleas, whose use in combination with the smaller sizes will give the irregularity of mass and profile so necessary to proper appearance.

For the planting of screens and windbreaks or for planting singly, we have in our Nurseries Oaks and Maples up to 30 or 40 feet in height, which can be combined with the large sizes of Norway Spruce, Austrian and White Pine, to secure results at once that would otherwise entail years of waiting.

Many of these Iarge plants cannot be properly described in a catalog and we are always glad to send descriptions or photographs in answer to inquiries for these extra-large sizes of nursery-grown plants.

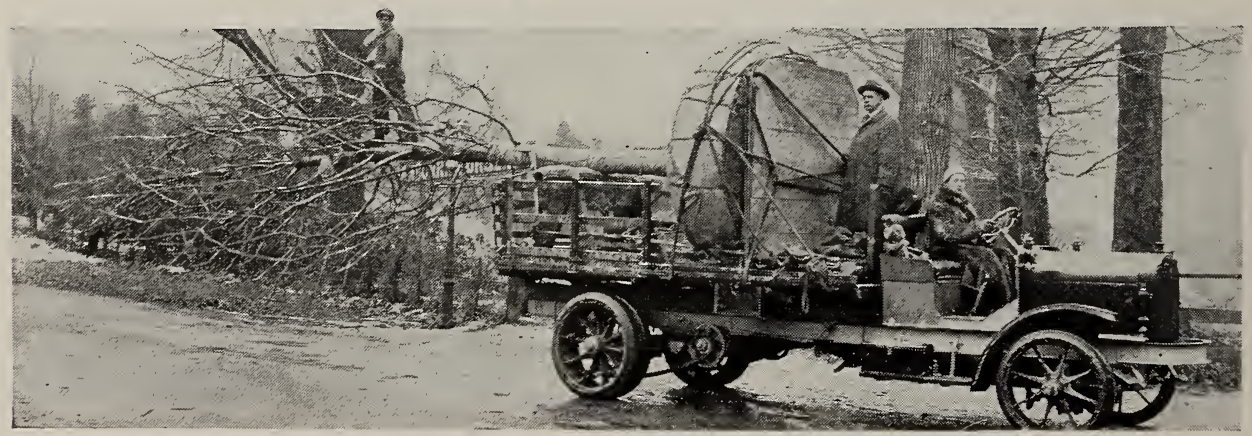

Moving large tree with fibrous feeding-roots protected. This gives immediate effect 


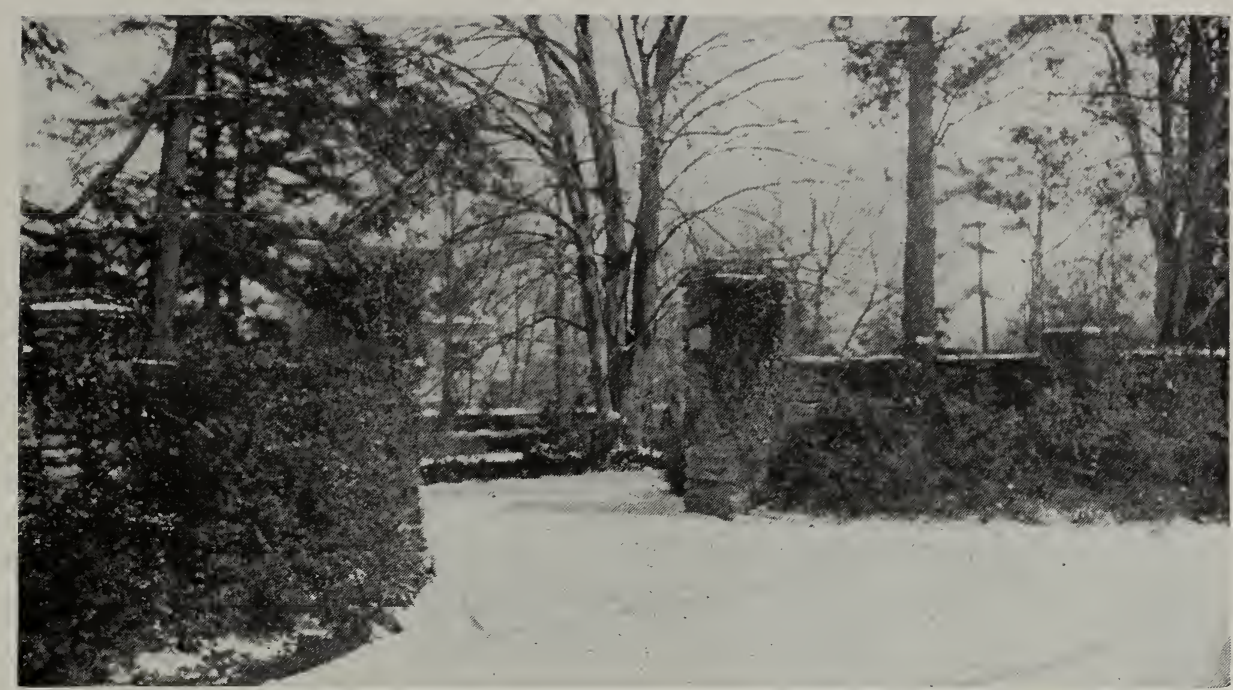

Japanese Hollies grouped at the gateway make the entrance inviting at all seasons

\section{Broad-leaved Evergreens Valuable for Berries, Form, and Foliage}

$\mathrm{M}$

ANY of these plants are introductions from Japan and have long hidden themselves away under burdensome Latin names, and consequently are not so well known or appreciated as their varied uses and individual charms well warrant. They are particularly adaptable for use with the more somber-toned conifers, where their bright berries or glossy leaves add a needed touch of color.

When varieties like the Japanese Hollies, Evergreen Thorns, and Barberries are used in plantings with some of the Evergreens of more severe outline and habit like the tall Junipers, Japanese Cypress, and Arborvitæs, they lend a feeling of freedom and lightness to a grouping which might otherwise appear stiff and unbending.

Many of these plants are appropriately used in situations where it is especially desired to soften strict architectural forms or outlines and where the planting must be in keeping in tone and richness, as in the forecourt or formal garden; here plants in the larger sizes may be arranged in loose groups or in scattered masses with admirable results. Others still, like the Mahonias, are admirable for planting along wooded walks, and nearly all are appropriately combined with the finer forms of deciduous shrubs, as they harmonize in form and habit and continue the beauty of the planting with Evergreen foliage through late fall and winter.

Not the least of the attractions of this class of plants is their habit of fruiting; the rich fall and winter coloring of the berries adds just the needed touch of brightness and enhances the rich tones of the Evergreen foliage. 


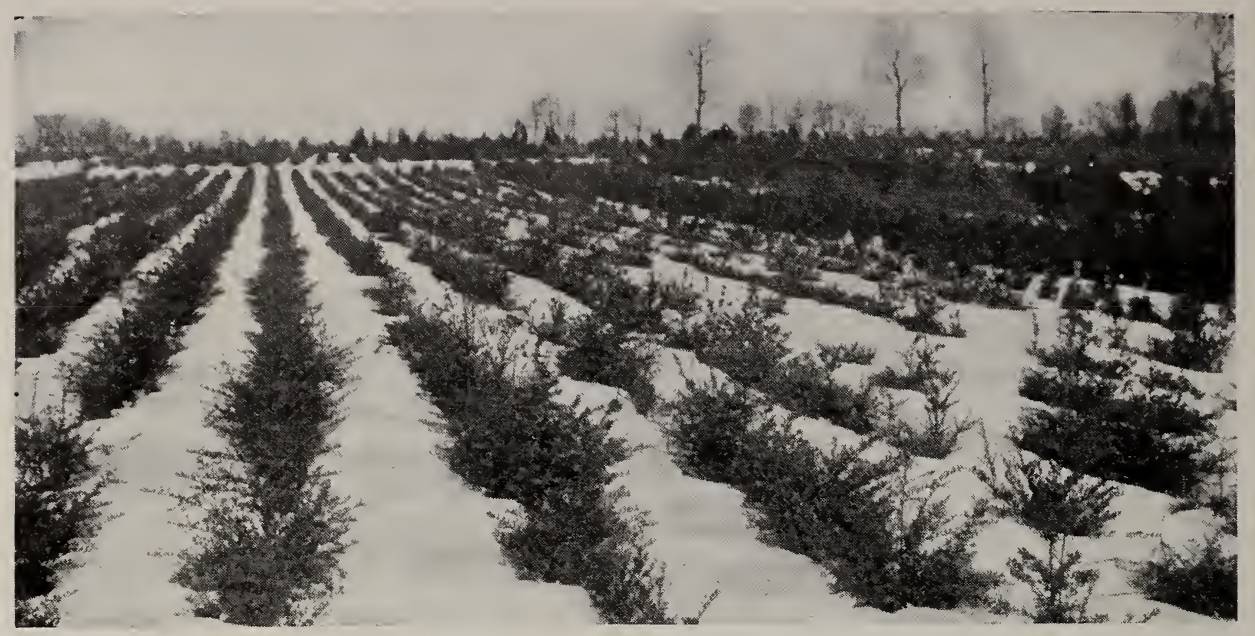

Andorra-grown Japanese Holly

Japanese Holly

Ilex crenata

A rare, beautiful, small-leaved bush, growing rather slowly to a height of several feet, naturally open in habit, but may be clipped to any desired form and is covered in Iate fall with a profusion of inky black berries. As a substitute for Boxwood in cold situations, it is without equal, as it stands below-zero temperatures. When clipped, it has much the same character as Boxwood, but is a richer, darker green and has not the odor of Box, to which some object. We cannot too highly recommend Japanese Holly and Japanese Boxwood for climates too cold for ordinary Box. Charming effects can be obtained by combining these varieties with the red-berried Japanese Winterberry.

We were the first to introduce the Japanese Holly, and can supply plants that we have grown for many years to Iarge sizes and which possess a distinctly Japanese effect. Our plants are grown widely apart and are consequently broad and bushy.

The variety Microphylla is especially adapted to use for Evergreen hedges. It is a vigorous grower but can be trimmed as desired, and it is not unusual to keep it in low hedge-form for many years.

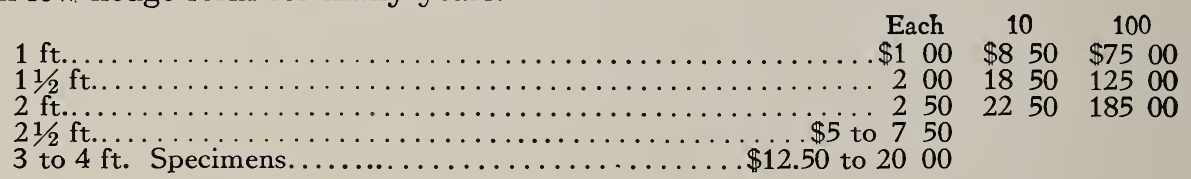

Box-leaved Japanese Holly

Ilex crenata, var. buxifolia

As the name signifies, it has leaves very like a Boxwood. Its growth is columnar, twigs close, foliage rich dark green.

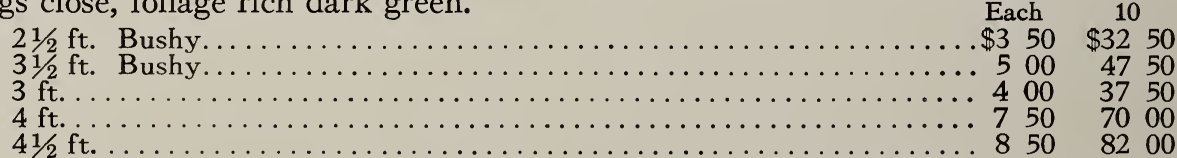

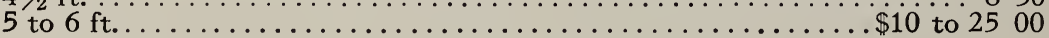

\section{Broad-leaved Japanese Holly}

Ilex crenata, var. latifolia

The broad, shining leaves lend a tone of richness and character to this variety. In habit a rapid, tall, open-growing form.

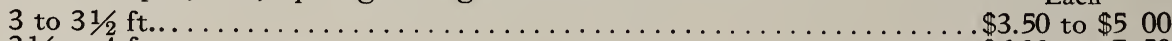

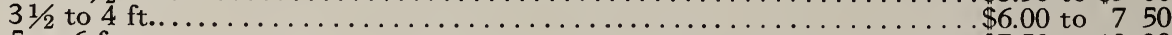

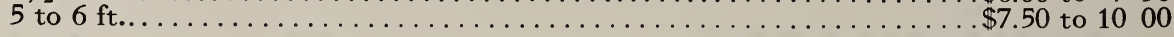




\section{Broad-leaved Evergreens Valuable for Berries and Foliage}

\section{Fortune's Japanese Holly}

\section{Ilex crenata, var. Fortunei}

Leaves rather more rounded and a little freergrowing than the type; at all seasons a rich shining green.

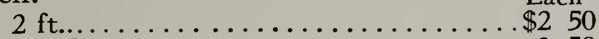

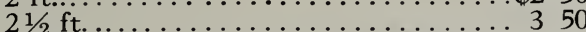

$3 \mathrm{ft} \ldots \ldots \ldots \ldots \ldots \ldots \ldots \ldots 7.50$ to 1000

$31 / 2$ to $4 \mathrm{ft} . \ldots \ldots \ldots \ldots \ldots \ldots \ldots 12.50$ to 2000

\section{Small-leaved Japanese Holly}

\section{Ilex crenata, var. microphylla}

Rapid-growing and naturally very dense, this variety stands shearing well and makes a hedge comparable in every way to Boxwood.

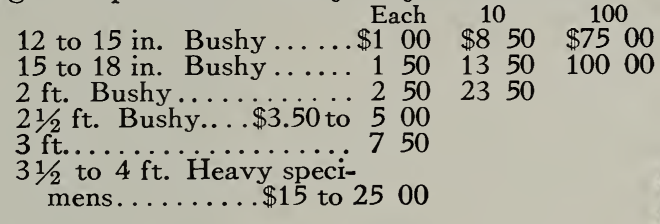

\section{Evergreen Thorn}

\section{Cratægus pyracantha (coccinea)}

A dense, slow-growing bush with shining green leaves, which in winter take on a wonderful ruddy color, like a coat of rich deep sunburn. The brilliant scarlet berries, borne in profusion, brave the winter storms until spring, when the shrub is covered with delicate white blossoms. It repays a little extra protection.

$1 \frac{1}{2}$ to $2 \mathrm{ft}$. Heavy clumps...... $\$ 250 \quad \$ 2250$

\section{Leland's Evergreen Thorn}

Cratægus pyracantha, var. Lelandii

Like the above, but with bright orange-red berries.

$\$ 2000$

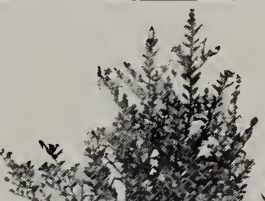

$11 / 2$ to $2 \mathrm{ft}$

2 to $2 \frac{1}{2} \mathrm{ft} . \ldots \ldots \ldots \ldots \ldots \ldots$

\section{English Holly}

Ilex aquifolium

The associations of brightness and cheer which this plant brings to mind in winter Iandscapes, make it well worth the extra care it must receive north of Philadelphia or Long Island, where it makes a handsome tree.

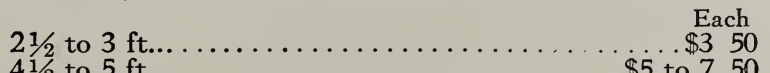

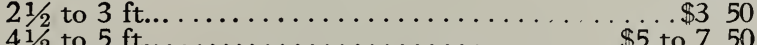

American Holly

Ilex opaca

Until robbed by collectors, this plant grew profusely in the swamps near Cape Cod and on Long Island. It is of easy culture in groups of Evergreens and hardier than the English Holly.

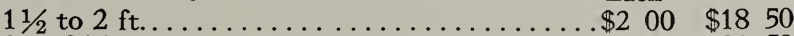

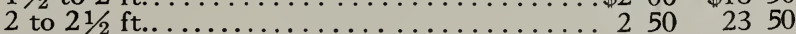

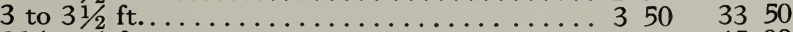

English Holly

$31 / 2$ to 4 f

500 


\section{$58 \quad$ Broad-leaved Evergreens Valuable for Berries and $F$}

\section{Evergreen Euonymus}

Euonymus japonica and varieties

An upright shrub with broad, dark green Iustrous leaves, compact in habit of growth and very desirable. A little protection is necessary in cold winters north of Washington. The silver-leaved and golden varieties are most attractive.

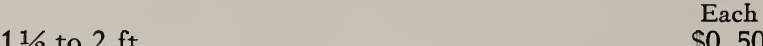

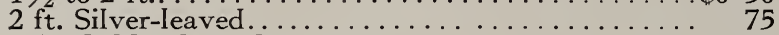

$2 \mathrm{ft}$. Golden-leaved........................ 75

10

$\$ 350$

600

600

\section{Chinese Quince Berry}

Cotoneaster horizontalis

Very low-spreading plant with curious horizontal branches covered in fall with smaII deep red berries. This attractive, new introduction and the following variety are unsurpassed for planting among the crevices of rocks. Requires the treatment due a slightly tender plant, north of New York.

8 to 12 in.

Each

10

Himalayan Quince Berry Cotoneaster microphylla

Quite similar to the above: foliage smaller; branches set closer together.

10 to 12 in.

Each

Each
$\$ 0 \quad 50$

$\$ 400$

Wheeler's Quince Berry Cotoneaster, var. Wheeleri

Can be used with the foregoing; growth stronger; foliage Iarger; fruit large and showy.

12 to 15 in

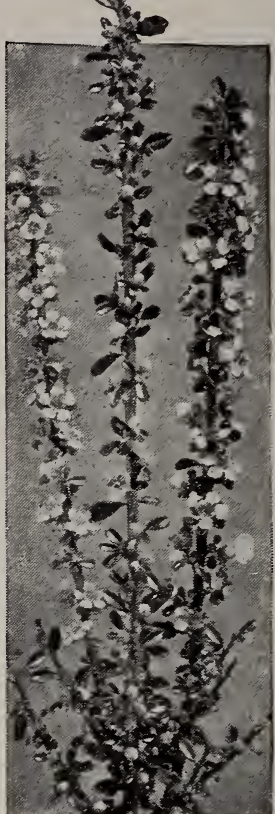

Himalayan Quince Berry

Each 10

$\$ 075 \$ 650$

Shiny-leaved Rose Box

Cotoneaster simonsii

A little-known shrub, with upright, spreading branches on which are borne clusters of smaII white flowers, followed by bright red berries. The leaves are deep, Iustrous green and are usually only semi-persistent. $\quad$ Each $10 \quad 100$

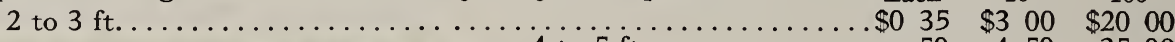

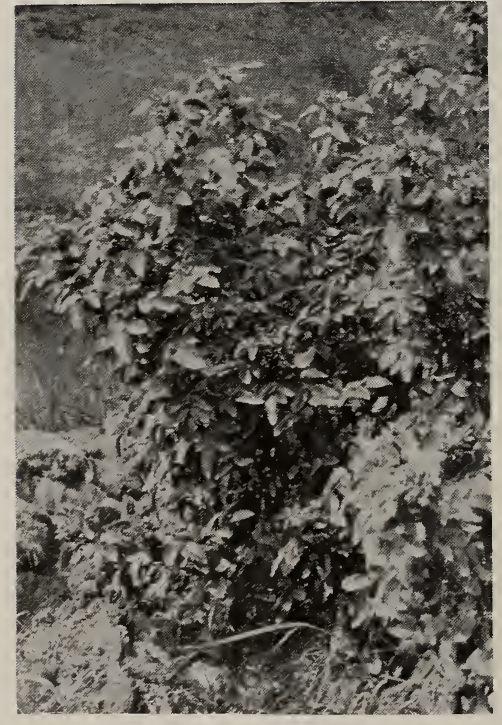

Holly-leaved Barberry 4 to $5 \mathrm{ft} . \ldots \ldots \ldots \ldots \ldots \ldots$. 50

$450 \quad 3500$

\section{Box-leaved Barberry Berberis dulcis}

From Chile and Patagonia. A Iow shrub whose rich glossy foliage, profuse yellow flowers in spring, and blue-black fruit amply reward us for the little extra protection it requires north of Long Island.

Each $10 \quad 100$

...... \$0 $50 \quad \$ 400 \quad \$ 3500$

18 to 24 in................ $75 \quad 600 \quad 5000$

\section{Holly-leaved Barberry}

Berberis ilicifolia

A native of Terra deI Fuego; its spiny graygreen leaves take on rich purplish tones in the late fall and are persistent till late winter. This shrub has most attractive orange-yellow flowers and deep purple berries; it, too, requires a sheltered home.

\begin{tabular}{|c|c|c|c|}
\hline 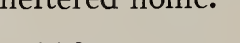 & Each & 10 & 100 \\
\hline $\begin{array}{l}11 / 2 \mathrm{ft} . . \\
2 \mathrm{ft} . \ldots\end{array}$ & $\begin{array}{l}\$ 035 \\
. \$ 5\end{array}$ & $\begin{array}{rr}\$ 3 & 00 \\
4 & 00\end{array}$ & $\begin{array}{r}\$ 2000 \\
2500\end{array}$ \\
\hline
\end{tabular}




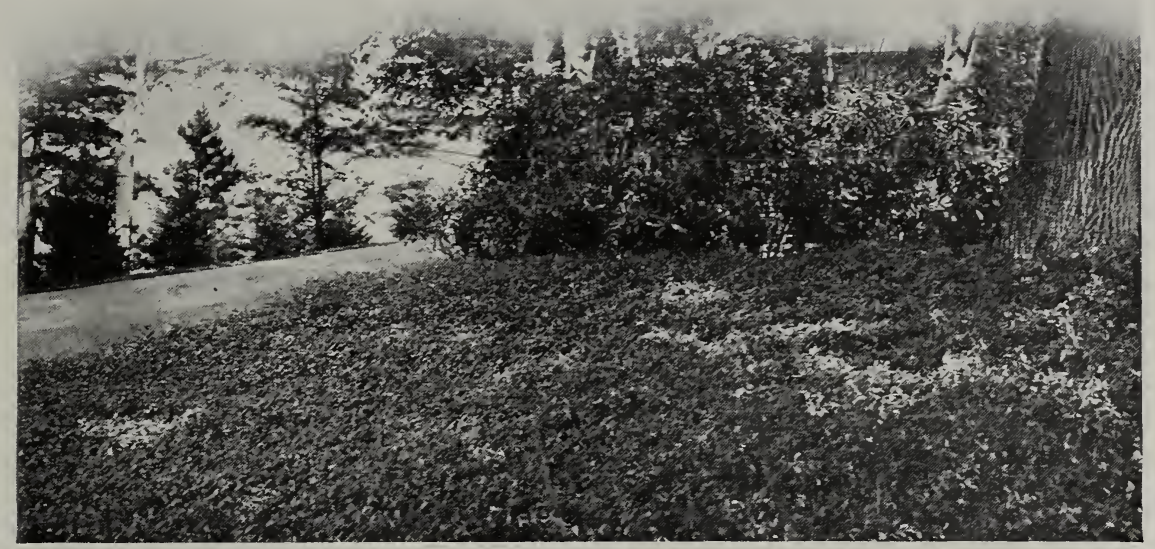

The ground under trees where grass will not grow is attractive when covered with some of these trailing Evergreen plants. Periwinkle bas been used in this case

\section{Evergreens for Ground-Covers}

T

$\mathrm{HE}$ following species are particularly valuable for carpeting the ground in shady places where grass will not grow weIl and as an attractive covering for the soil on beds or borders of Evergreens. Spring-flowering bulbs may be planted among these creeping Evergreens, which act as a pleasing background when the bulbs are in bloom.

\section{Periwinkle, or Myrtle}

Vinca minor

This hardy, old-fashioned, little, spreading Evergreen delights in cool shady places and so is unexcelled for carpeting the ground under trees. In spring it is changed almost overnight to a carpet of richest violet-blue by its tiny, star-shaped flowers, which also persistently appear throughout the summer.

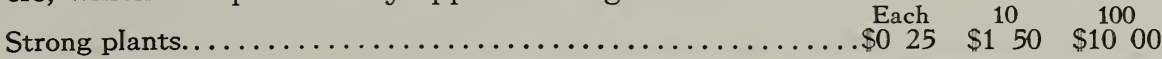

\section{Japanese Evergreen Ivy}

\section{Euonymus radicans}

Obscured by such names as Trailing Evergreen Creeper and Climbing Euonymus, this most attractive dark greenleaved, rapid-growing, clinging vine or creeper from Japan has escaped the attention which it weIl deserves. We have chosen rather to call it Japanese Ivy, as it resembles the well-known English Ivy in its habit of growth, although it is much hardier than English Ivy, and is applicable for the same uses on walls, foundations of houses, on tree trunks, and as an admirable undergrowth for other Evergreens. It is also most desirable as a ground-cover in shady places. The varieties following all possess some distinctive charm and are equally desirable.

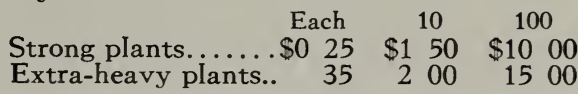

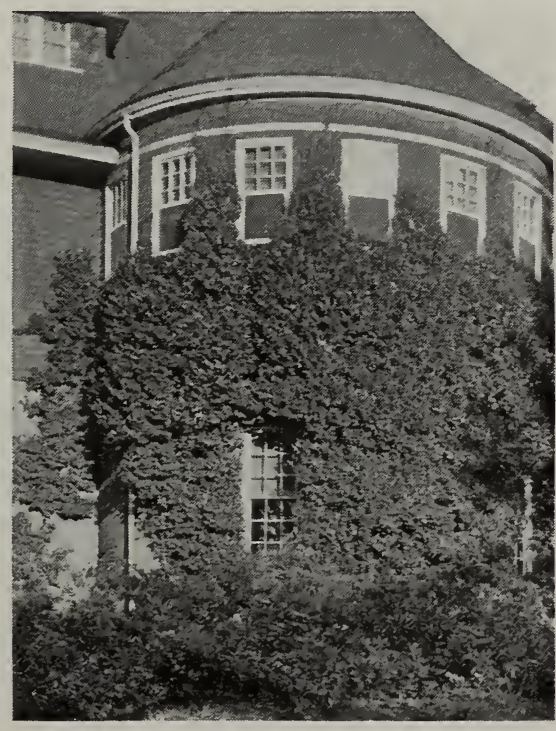

Japanese Evergreen Ivy on a wall. Equally effective when grown as a ground-cover 


\section{Variegated Japanese Evergreen Ivy}

\section{Euonymus radicans, var. variegata}

Leaves about an inch long and narrow, like the type, but variegated with silvery white.

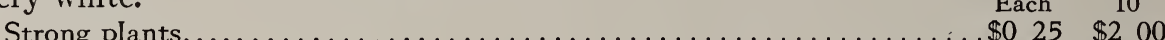

\section{Carriere's Japanese Evergreen Ivy}

\section{Euonymus radicans, var. Carrierei}

This variety has Iarger, wider leaves of a bit warmer green than the type and does not cling quite so flatly to the surface on which it grows, being of more informal appearance.

$\begin{array}{ccc}\text { Each } & 10 & 100 \\ \$ 035 & \$ 300 & \$ 2500 \\ 75 & 6 & 00\end{array}$

\section{Scarlet-fruited Japanese Evergreen Ivy}

\section{Euonymus radicans, var. vegeta}

Habit of growth similar to the above, and in the fall is conspicuous for its clusters of orange-scarlet berries.

Strong plants..............................\$ $3035 \$ 3300 \$ 2500$

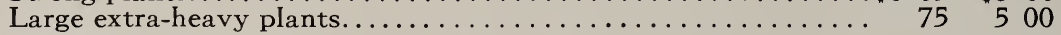

\section{English Ivy}

Hedera helix

The close-clinging, dark green of this vine has almost a classic significance, so long has it covered the walls of cottage and castle alike in England and continental Europe. It may be used freely as a ground-cover, and even in the densest shade it forms a carpet of richest green.

Each $10 \quad 100$

Potted plants..............................\$0 25 \$2 $00 \$ \$ 1500$

\section{Japanese Spurge}

\section{Pachysandra terminalis}

A less formidable name than that which the botanists devised, for it would have helped to draw attention more generally to this plant. Its welcome little spikes of white flowers in spring convert the quick-spreading carpet of dark green, which it soon forms, into a fairy, flowered forest. This low Evergreen grows equally well in shade or sunshine, and as a cover for the ground in beds of Evergreens it is admirable.

Each

$10 \quad 100$

Strong plants.

$\$ 025$

$\$ 200 \$ 1500$

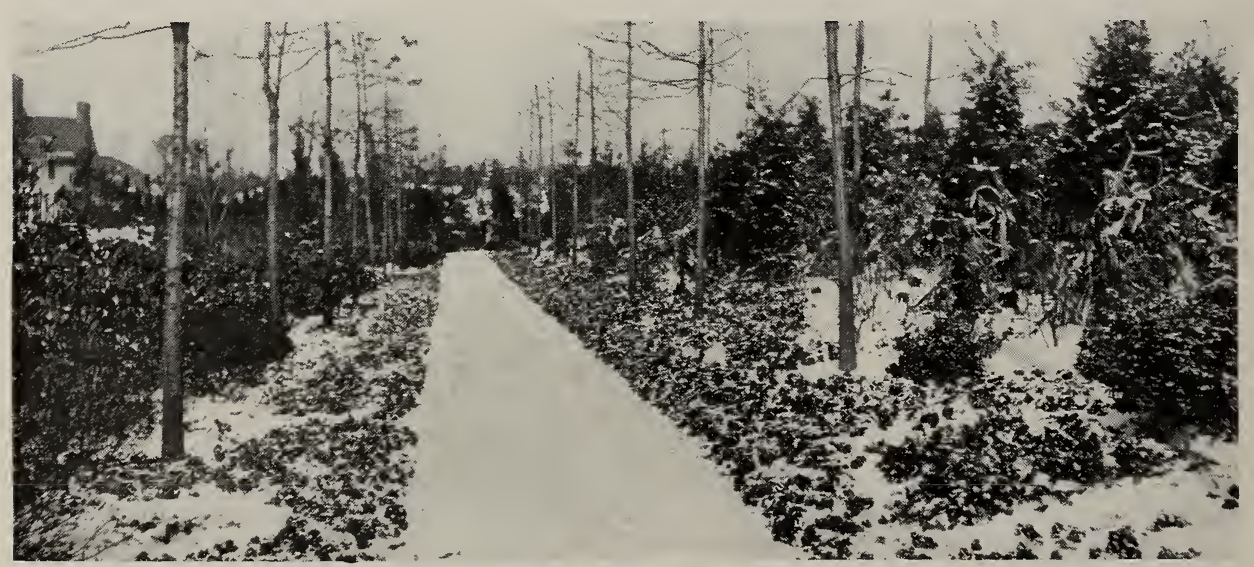

Japanese Spurge used as a ground-cover and forming an attractive background for the brightflowered bulbs which appear in the spring 


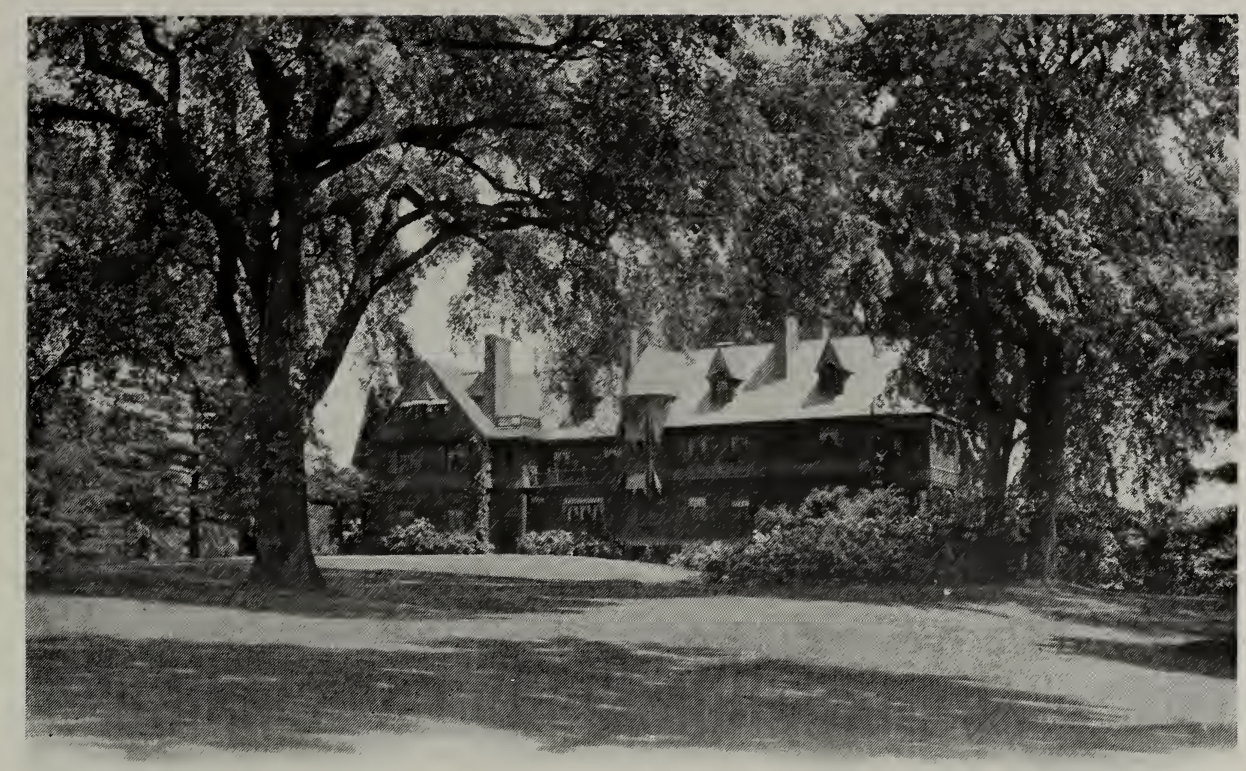

\section{Deciduous Trees}

$\mathrm{N}^{\circ}$

O MATTER whether the grounds be of large extent or of small size, the value of trees as a basis of arrangement of the homegrounds or landscape design is most important. Nothing else can impart that quality of quietness and appearance of permanency that is lent by fine trees. Many times we attempt a short-cut in our eagerness to obtain this effect quickly by the use of very rapid-growing trees which unfortunately are not long-lived and from the very nature of their quick growth of soft wood are exposed especially to the dangers of ice- and windstorms. In planting groups of trees as in screens or windbreaks, the use of the more rapid-growing varieties is justifiable provided there are also used a proper number of more permarient, slow-growing trees to take their places later on.

Where trees are set out as specimens for shade about the house or for avenues, it is better to start with the larger sizes of the

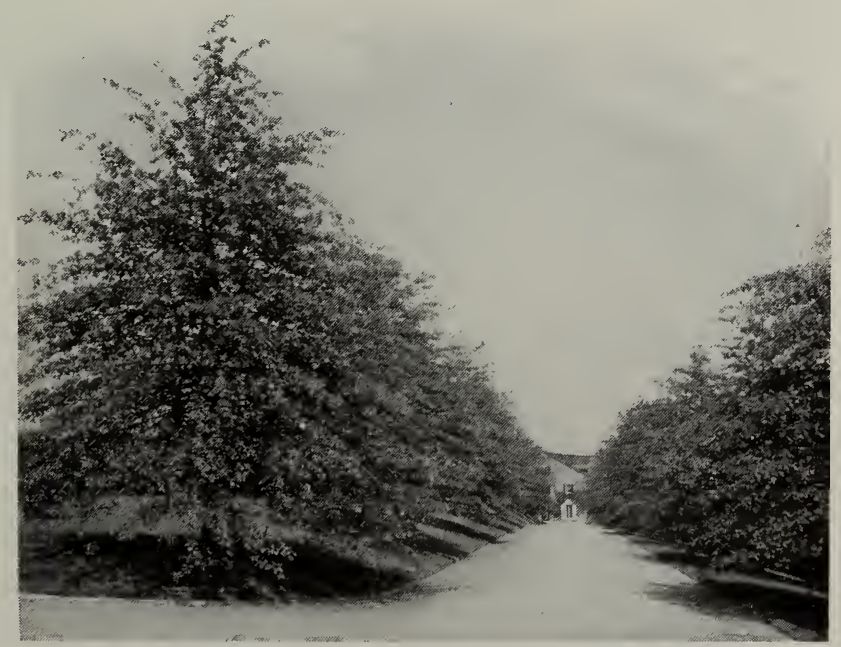

An avenue of Pin Oaks, where brancbes bend gracefully almost to the ground 
slower-growing varieties with the certainty that, although the first cost may be a little greater, the effect of dignity and permanence for which you are striving will be most surely and quickly obtained. The cost of planting and yearly care is practically the same, whether the tree that is set out be large or small, of a permanent variety, or one which at the end of a few years will begin to deteriorate. Our trees are planted wide apart in the nursery and are frequently transplanted, thus developing a good top and a fine system of fibrous roots. You will note that many of them are in extra-large sizes which will transplant successfully and obviate years of tiresome waiting for their shade and proper effect.

There will naturally be found many species whose uses are varied; for instance, the pleasing effect of Flowering Trees suggests their use as specimens, or in groups in boundary planting, or to brighten the Iawnside of a screen planting, or again as avenue trees. The Oak, the Ash, and Maple also adapt themselves to any of these situations, although we are more apt to think of them for street planting or specimens. Below is the grouping under which we have cataloged our stock.

\section{DECIDUOUS TREES}

Street and Roadside Trees page 63.

Trees for Specimens and Landscape Grouping, page 71.

Flowering Trees, page 77.

Trees for Boundaries, Screens, and Windbreaks, page 89.

TaIl-growing, page 89.

Medium height, like very tall shrubs, page 93.

Trees with Colored Foliage, page 95.

Deciduous Conifers, page 97.

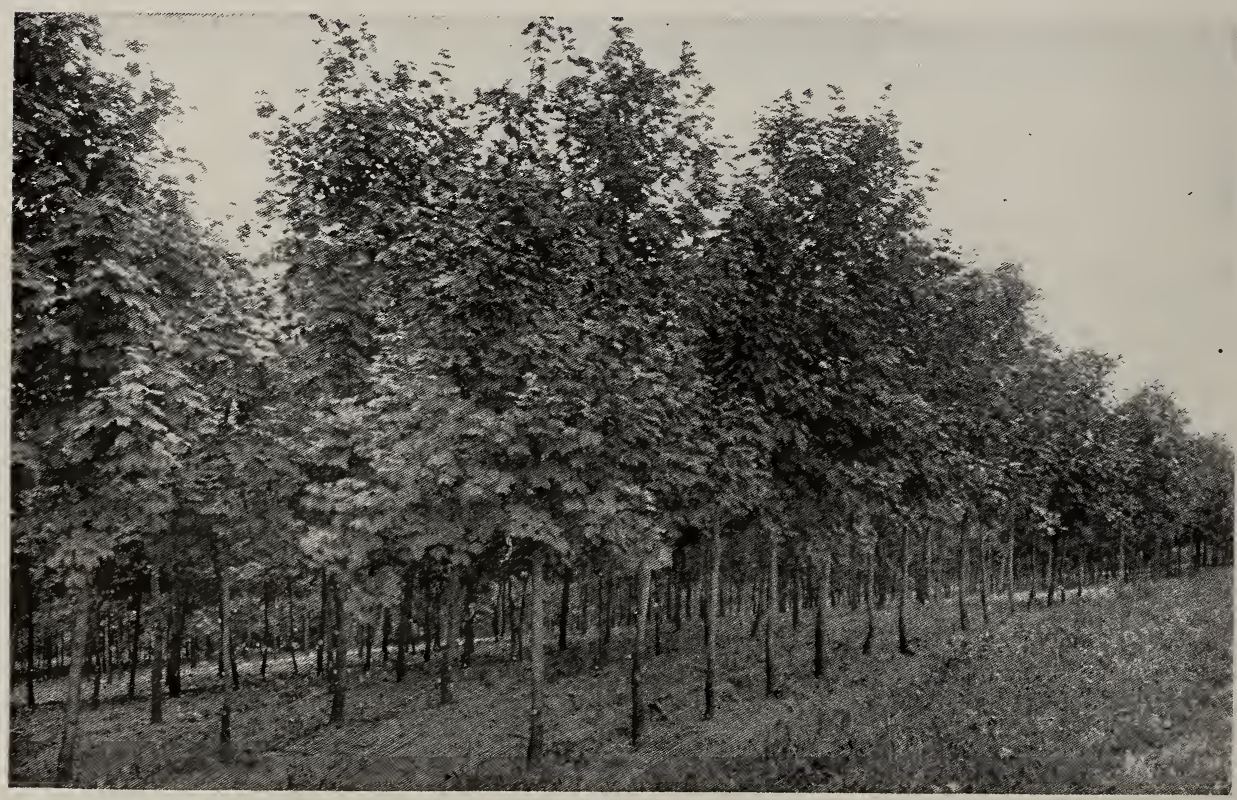

Our trees are grown wide apart, with ample space for development of a broad top and good roots 


\section{Deciduous Trees for Street and Roadside}

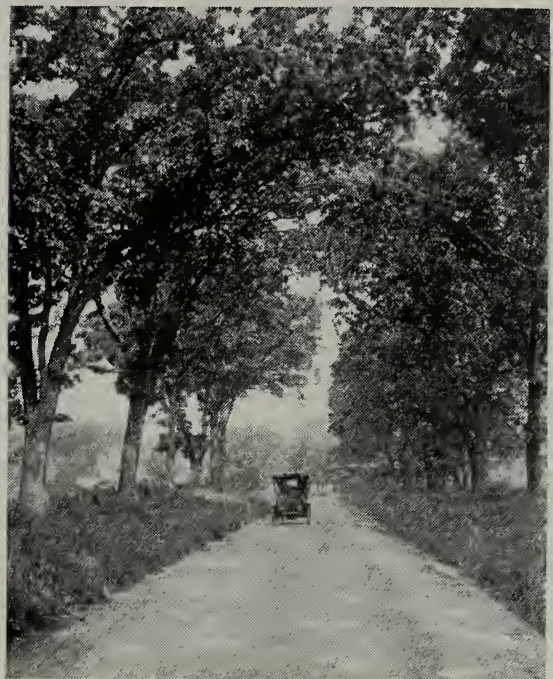

An ideal, sbady country road
B

$Y$ SOME unfortunate chance we have neglected a great opportunity for beautifying the country roadsides by the planting of permanent shade trees, and our roads through the country are apt in summer to be glaring, dusty stretches, or else the fence-rows have been allowed to grow up with short-lived "weed trees" and brush, a menace to the neighboring fields, for they are a breeding-place for insect and fungous diseases and vermin of every sort. This uninviting appearance of neglect can be changed to one of neatness and direct economic value to your property by planting trees at regular intervals or in naturalesque groups. The Oaks, Lindens and Hard Maples are among those adapted for use on high, well-drained ground, and for more moist situations there are the Elm, Sweet Gum and Plane, while numberless other species permit a wide variety of choice.

For street planting in town and city, trees should be chosen that are of persistent rapid growth, for in our busy American life it is surprising how soon the apartment house supplants the suburban home or cosy cottage. Two trees which are to be especially recommended for their ability to thrive under the trying conditions of street-planting, which are free from insect pests, and which rapidly supply an abundance of shade, are the Oriental Plane and Norway Maple. Both of these trees are fast, vigorous growers and naturally form low, broad, symmetrical heads of heavy foliage making them ideal for use in suburban developments where immediate results are required in the street planting.

As with all our stock, great care is taken, by setting the trees wide apart in the nursery rows, trimming, and frequently transplanting, to produce trees which are superior in every way to those ordinarily offered, superior in sturdy trunks, well-formed heads, and, most important, superior in root-systems, with abundant fibrous feedingroots. Thus the buyer is repaid by the better results obtained in the use of Andorra-grown trees.

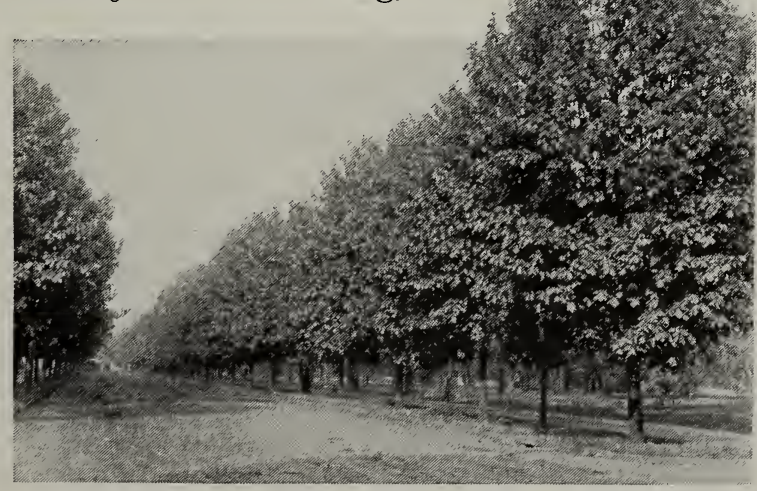

Rows of stately trees at regular intervals enbance the appearance of any town or city 


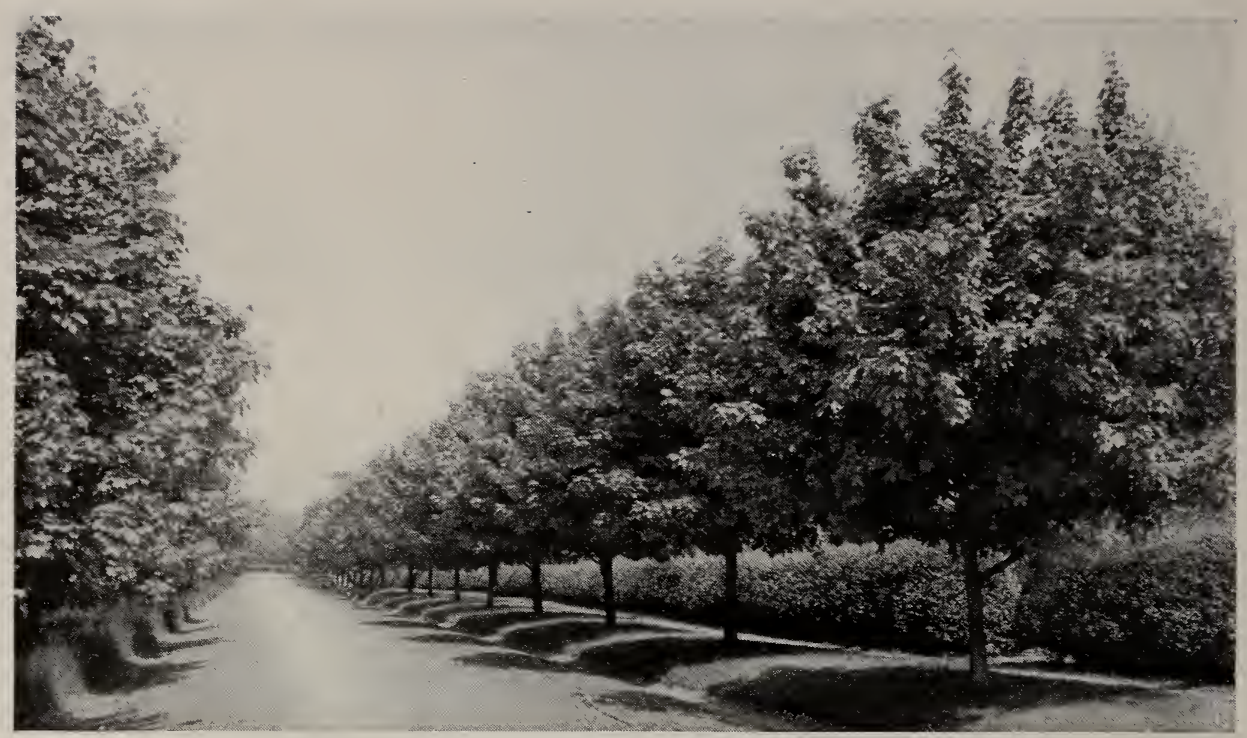

The Norway Maple forms a broad, rounded bead, casting dense shade

White or Silver Maple

Acer dasycarpum

In outline and habit of growth, this tree somewhat suggests the American Elm; it adapts itself to a variety of soils, with the exception of dry ground, and is a rapid grower.

Each $10 \quad 100$

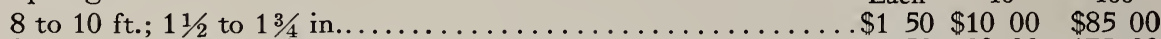

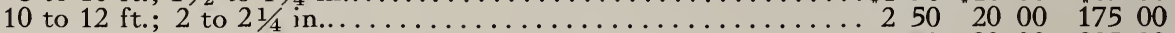

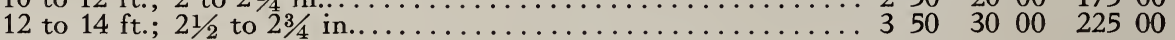

\section{Norway Maple}

Acer platanoides

We are fortunate in being able to offer trees that have been grown wide apart so that there has been a chance for individual development of top and root-system; they have been frequently transplanted and lift with a wonderful system of fibrous roots. These trees are not to be compared for an instant with the stock ordinarily offered by others, grown very closely together and sometimes not transplanted from the time they left the seed-bed until sold. We especially call your attention to the diameter of the trunk as a gage of the substantial character of these trees as compared with light, thin-stemmed trees with poor roots. These trees will form the dense, wide, round-headed top which makes this quick-growing variety so valuable for street planting, withstanding adverse conditions. Each

8 to $10 \mathrm{ft} . ; 1$ to $11 / 4$ in ............................. 00

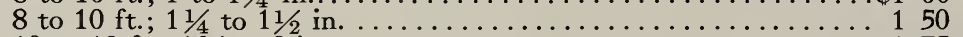

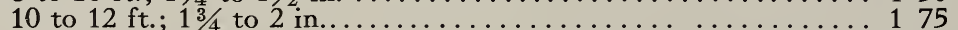

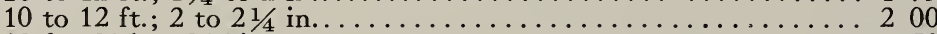

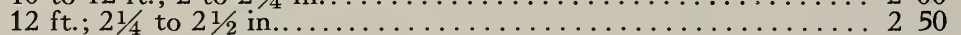

12 to $14 \mathrm{ft}$; $21 / 2$ to $23 / 4$ in........................... 350

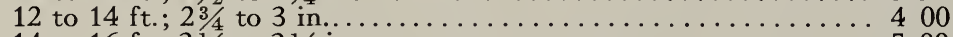

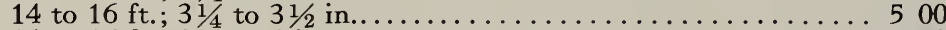

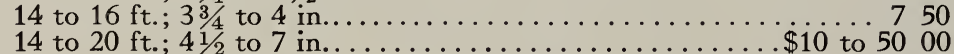

10100

$\$ 750 \quad \$ 50 \quad 00$

$1000 \quad 6000$

$1350 \quad 11500$

175010500

200016500

$2750 \quad 25000$

$3250 \quad 27500$

$4750 \quad 40000$

\section{Sycamore Maple}

Acer pseudoplatanus

The most beautiful of the European Maples, holding its leaves in fall Ionger than our natives; a tree of medium height and vigorous growth. Each 10

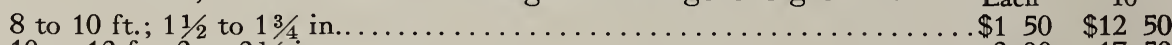

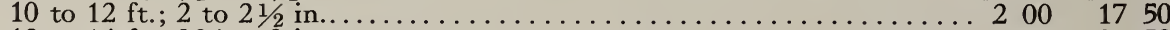

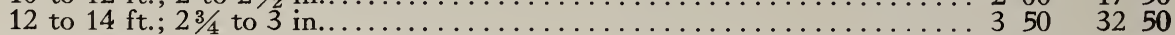

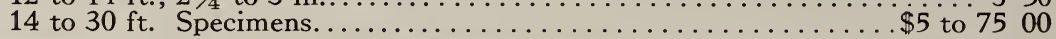




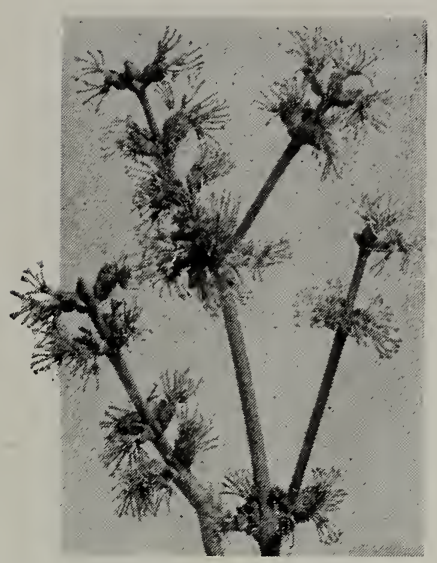

Flowers of the Red Maple

\section{Red Maple}

Acer rubrum

One of the most strikingly beautiful trees in the fall on account of its vivid crimson foliage coloring. The bright red buds in spring, as seen against the gray, smooth branches, are most attractive. A spreading, tall tree which makes a fine specimen; especially good for moist situations.

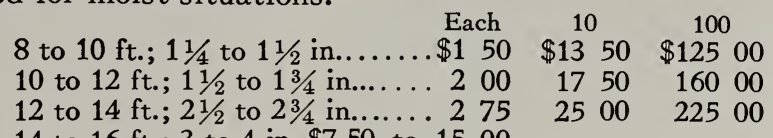

14 to $16 \mathrm{ft} ; 3$ to 4 in. $\$ 7.50$ to 1500

\section{Sugar or Rock Maple}

Acer saccharinum

In its early growth the head of dense foliage often resembles a graceful oval; Iater it assumes the form of a broad leafy dome. It is always erect and neat in appearance, adapting itself to a variety of situations, except boggy ground. A most beautiful permanent shade tree, taking on vivid tints of autumn color.

\begin{tabular}{|c|c|c|}
\hline $\begin{array}{l}10 \text { to } 12 \mathrm{ft} . ; 11 / 4 \text { to } 11 / 2 \text { in... } \\
10 \text { to } 12 \mathrm{ft} \text {.; } 11 / 2 \text { to } 13 / 4 \mathrm{in} . . \\
12 \text { to } 14 \mathrm{ft} \text {.; } 2 \text { to } 21 / 4 \text { in..... } \\
12 \text { to } 14 \mathrm{ft} . ; 21 / 2 \text { to } 23 / 4 \text { in... } \\
12 \text { to } 14 \mathrm{ft} \text {.; } 23 / 4 \text { to } 3 \text { in...... }\end{array}$ & 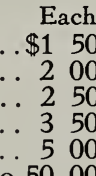 & $\begin{array}{rl} & 10 \\
\$ 12 & 50 \\
1750 \\
2250 \\
3250 \\
4500\end{array}$ \\
\hline
\end{tabular}

14 to $25 \mathrm{ft}$; 3 to 6 in............................... $\$ 10$ to 5000

\section{Tree of Heaven}

\section{Ailanthus glandulosa}

For use in the poorest soil or for smoky cities this tree is unexcelled. Of Ioose, graceful habit of growth and luxuriant tropical foliage.

10 to $12 \mathrm{ft} . ; 1 \frac{1}{2}$ to 2 in

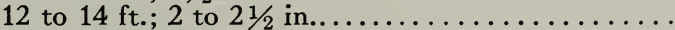

\begin{tabular}{|c|c|c|}
\hline Each & 10 & 100 \\
\hline $\begin{array}{ll}\$ 1 & 00 \\
1 & 25\end{array}$ & $\$ 850$ & $\$ 6000$ \\
\hline
\end{tabular}

\section{White Ash}

\section{Fraxinus americana}

A tall, stately, symmetrical tree, thriving best in rich soil, moist rather than dry. In the autumn the coloring of the foliage is most unusually beautiful in shades of purplish bronze. It is a long-lived tree of excellent habit, and its clean gray trunk gives the idea of sturdiness. Few trees are more desirable for avenue planting.

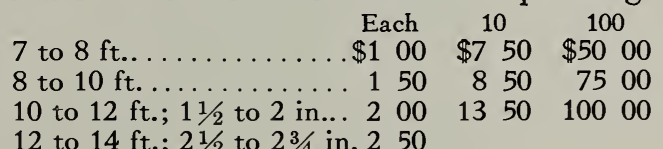

\section{Green Ash}

\section{Fraxinus lanceolata (viridis)}

A tree with shapely, round-topped head of dark green leaves. Essentially a tree for use where its feeding roots are supplied with an abundance of moisture. It gives most excellent results in deep heavy soils, holding a rich heavy foliage.

$$
\begin{aligned}
& \begin{array}{rrr}
\text { Each } & 10 & 100
\end{array} \\
& 8 \text { to } 10 \mathrm{ft} \cdot 11 / 2 \text { to } 13 / 4 \text { in } 150 \\
& 10 \text { to } 12 \mathrm{ft} \text {.; } 13 / 4 \text { to } 2 \text { in.. } 2001500
\end{aligned}
$$

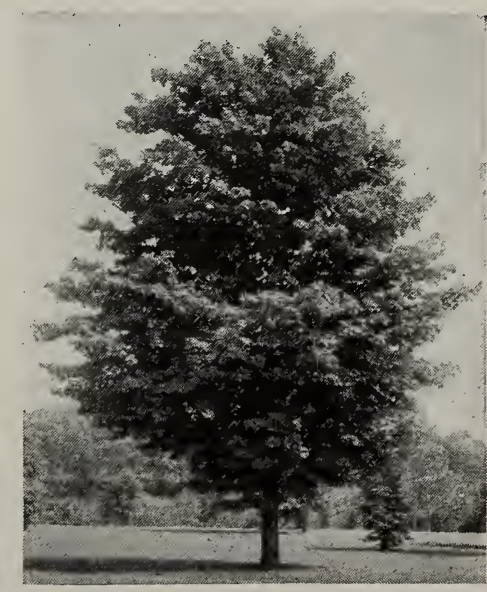

Sugar Maple 


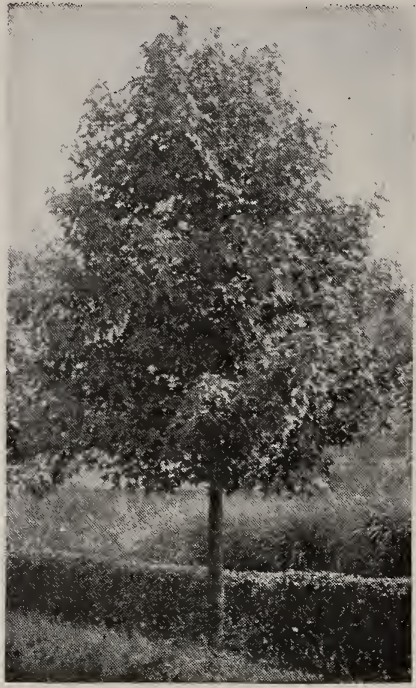

Sweet Gum

\section{Sweet Gum}

A symmetrical, medium-growing tree of great value on account of its brilliant autumn coloring, interesting winged twigs, and fruit resembling that of the Buttonwood. Thrives best in rich, moist soil but will also grow weIl on high ground.

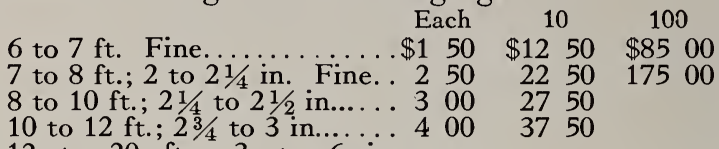

12 to $20 \mathrm{ft}$.; 3 to 6 in.

Specimens also......\$5 to 5000

\section{American Buttonwood}

Platanus occidentalis

A tall, vigorous, rugged, broad-spreading native tree, whose charm in winter is in its branches, mottled snow-white where the thin bark scales off, and its dainty seed-clusters, the "buttonballs."

$$
\begin{aligned}
& \text { Each } 10
\end{aligned}
$$

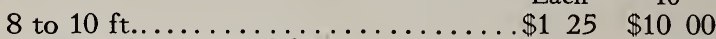

$$
\begin{aligned}
& 10 \text { to } 12 \mathrm{ft} . ; 13 / 4 \text { to } 2 \text { in................. } 175 \quad 1650
\end{aligned}
$$

\section{Platanus orientalis}

The proprietor of the Nurseries saw this tree in Europe many years ago and, realizing its great value as a street tree admirably adapted for city planting, introduced it extensively in this country. We have made a specialty of growing the Oriental Plane, spaced wide apart in the nursery rows, insuring a fine symmetrically developed top, while frequent transplanting creates a thick, fibrous root-system. Our trees are immeasurably superior to those grown without the care which we exercise, and will produce the most satisfaction and quickest results.

This rapid-growing, symmetricaI, wide-spreading tree, together with the Norway Maple, is most suitable for city street planting, successfully withstanding the adverse conditions of smoke, dust, and drought. It is also a fine avenue or lawn tree.

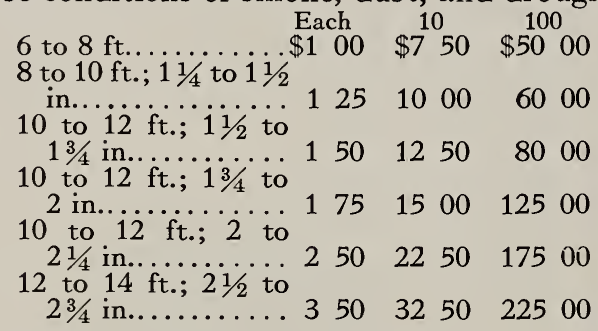

\section{American Linden, or Basswood}

\section{Tilia americana}

A tree of great value on account of the dense shade cast by its broad, round top, especially suitable in parks and country places. Its pretty little blossoms attract the bees, so that the tree seems fairly to hum when in flower. Each $10 \quad 100$

8 to $10 \mathrm{ft}$.; 2 to $21 / 4$ in. $\$ 200 \$ 1750 \$ 15000$ 10 to $12 \mathrm{ft} . ; 21 / 4$ to

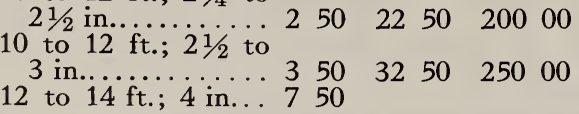

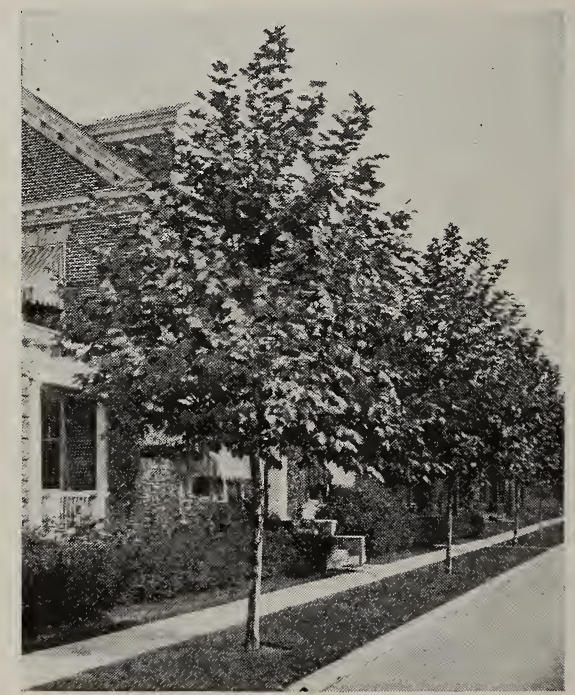

Oriental Plane in narrow parking space, where it grows successfully 


\section{Silver-leaved Linden}

Tilia tomentosa (argentea)

Among the finest of ornamental trees, of broad, shapely, pyramidal habit of growth; with the wind blowing, the silvery sheen of the under side of the leaves makes a charming picture.

7 to $8 \mathrm{ft}$; $13 / 4$ to 2 in........................ $\begin{gathered}\text { Each } \\ 50\end{gathered}$

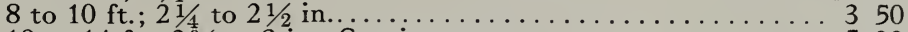

10 to $14 \mathrm{ft} . ; 2 \frac{3}{4}$ to $3 \mathrm{in}$. Specimens................. 500

\section{Large-leaved Linden}

\section{Tilia platyphyllos}

A stately, symmetrical tree, the Iargest of the European Limes, bearing fragrant flowers. It is valuable for avenue or lawn planting.

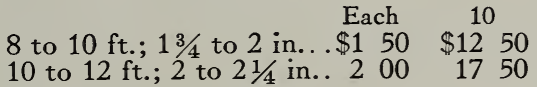

\section{European Linden, or Lime Tree Tilia vulgaris (europæa)}

A handsome, symmetrical tree of vigorous growth. This tree is used abroad, planted closely together, the tops clipped to form Iong, formal allees; and, in Holland, it is planted beside the canals, the side next the houses being cut away entirely to admit light and air to the houses, the trees forming a sort of spreading green fan before the buildings. It is one of the most desirable trees for formal avenues in towns or country.

\begin{tabular}{|c|c|c|}
\hline Each & 10 & 100 \\
\hline $\begin{array}{l}8 \text { to } 10 \mathrm{ft} . ; 2 \text { to } \\
21 / 4 \text { in. } \ldots 21 / 200 \\
10 \text { to } 12 \mathrm{ft} ; 2 \frac{1}{2}\end{array}$ & $\$ 1850$ & $\$ 17500$ \\
\hline $\begin{array}{l}\text { to } 23 / 4 \text { in... } 350 \\
2 \text { to } 16 \mathrm{ft} . ; 3 \text { to } \\
5 \text { in... } \$ 5 \text { to } 1500\end{array}$ & 3250 & 27500 \\
\hline
\end{tabular}

\section{Red-twigged Linden}

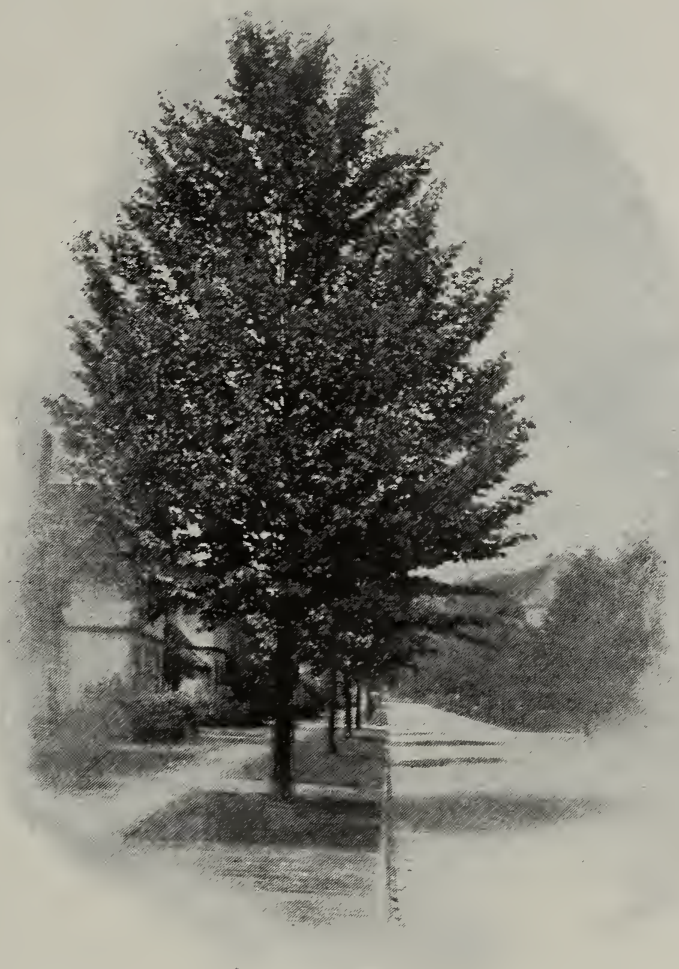

Linden

Tilia vulgaris, var. rubra

A dense, round-headed top of dark green. The bark of the small branches and twigs possesses a pretty dark reddish cast in winter.

10 to $12 \mathrm{ft}$; 2 to $2 \frac{1}{4} \mathrm{in}$.

Each $\quad 10 \quad 100$

$\$ 200 \quad \$ 1850 \quad \$ 17500$

\section{White Oak}

Quercus alba

The stately dean of native Oaks, slow-growing but always interesting, holding its dry, purplish brown !eaves nearly all winter.

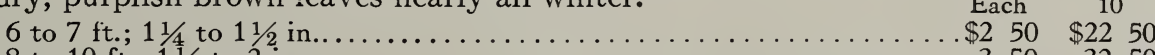

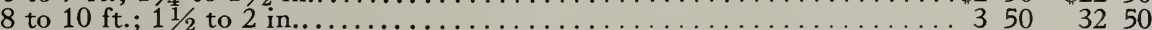

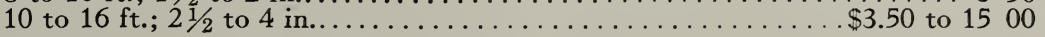

\section{Swamp White Oak}

Quercus bicolor (platanoides)

A beautiful tree, growing naturally in very wet ground, but almost equally at home in well-drained soil. Plant as a specimen or in groups.

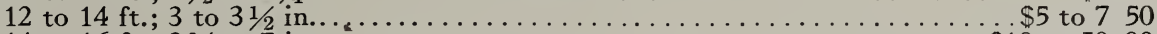

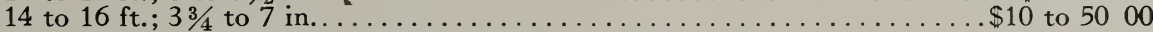




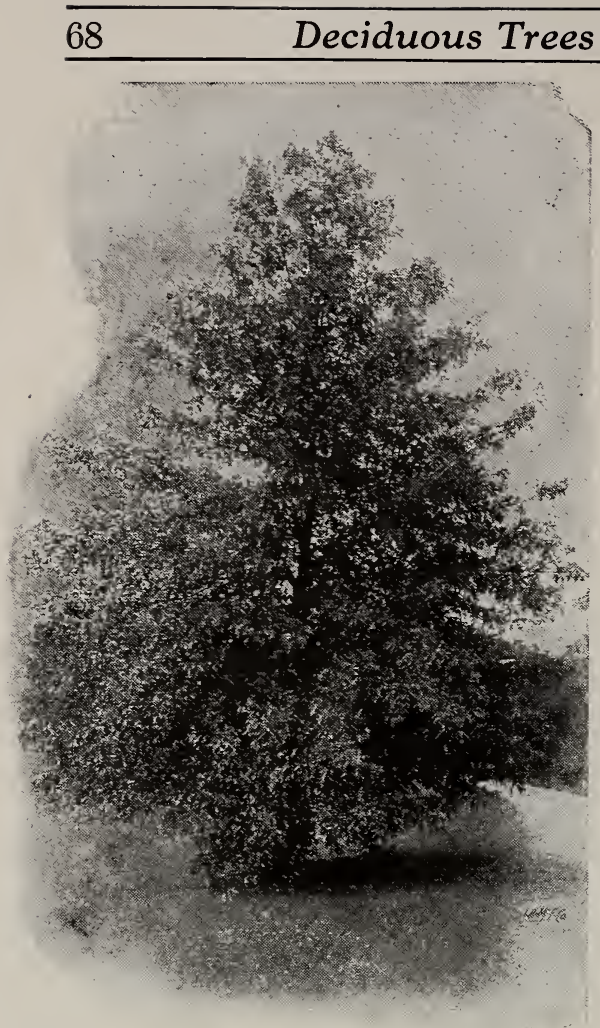

Pin Oak

\section{Scarlet Oak}

Quercus coccinea

Symmetrical and eminently fitting as a specimen tree, taking on the most gorgeous shades of brilliant scarlet in the fall and holding its dried leaves during the winter. Difficult to transplant, unless supplied with a good fibrous root-system which ours have.

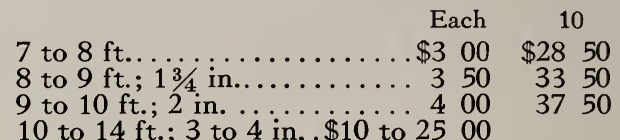

\section{Pin Oak}

\section{Quercus palustris}

A graceful tree of spreading, pyramidal habit and equally useful for lawn, avenue, or street planting, as it is comparatively rapid in its growth, at the same time being a long-lived permanent tree.

$$
\text { Each } 10 \quad 100
$$

$$
\begin{aligned}
& 6 \text { to } 7 \mathrm{ft} \text {; } 11 / 4 \text { to } 11 / 2 \text { in. } \$ 150 \$ 1350 \$ 13500
\end{aligned}
$$

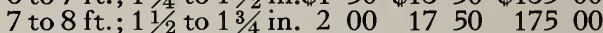

$$
\begin{aligned}
& 8 \text { to } 9 \mathrm{ft} \text {.; } 13 / 4 \text { to } 2 \mathrm{in...2} 50225022500 \\
& 10 \text { to } 12 \mathrm{ft} \text {; } 2 \text { to } 21 / 4 \text { in. } 300 \quad 2850 \quad 27500 \\
& 10 \text { to } 12 \mathrm{ft} \text {; } 2 \frac{1}{2} \text { to } \\
& 23 / 4 \text { in......... } 350 \quad 3250 \\
& 3 \text { to } 33 / 4 \text { in... .\$5 to } 1250 \\
& 12 \text { to } 35 \mathrm{ft} \text {; } 4 \text { to } 8 \mathrm{in} \text {. } \\
& \text { Extra-heavy speci- } \\
& \text { mens, well-rooted and } \\
& \text { with good tops. } \\
& \$ 15 \text { to } 12500
\end{aligned}
$$

Quercus rubra

\section{Red Oak}

Becomes a stately, spreading, clean-limbed tree with rounded head. The shining deep green leaves turn rich dark red in autumn.

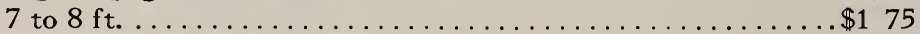
Each

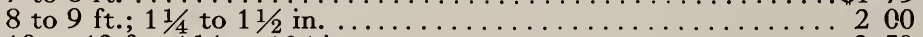

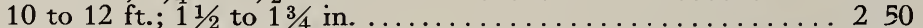

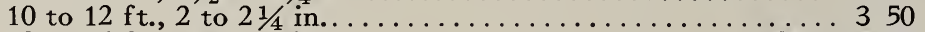

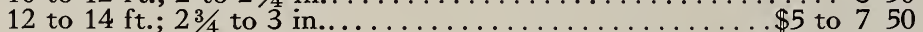

14 to $16 \mathrm{ft} . ; 31 / 2$ to 6 in....................... $\$ 10$ to 9000

$10 \quad 100$

$\$ 1650 \$ 15000$

$1850 \quad 16500$

$2000 \quad 17500$

$3000 \quad 27500$

\section{Black Oak}

\section{Quercus velutina}

TaII and stately; a dignified permanent tree, holding its rustling brown leaves in winter.

Each 10

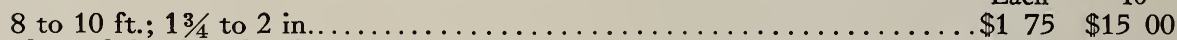

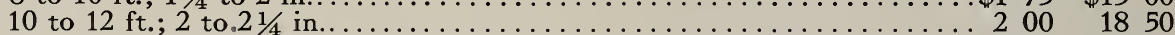

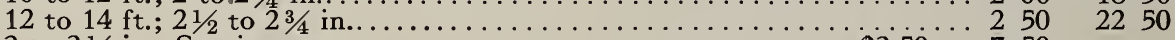

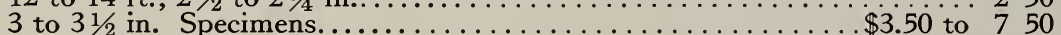

\section{American Elm}

Ulmus americana

One instinctively couples the adjective, "graceful," with the EIm, and justifiably, as no other tree has quite that appearance of airiness and grace which its arching branches create. No better recommendation can be advanced for its use as a street tree than the stately avenues in New England towns and villages.

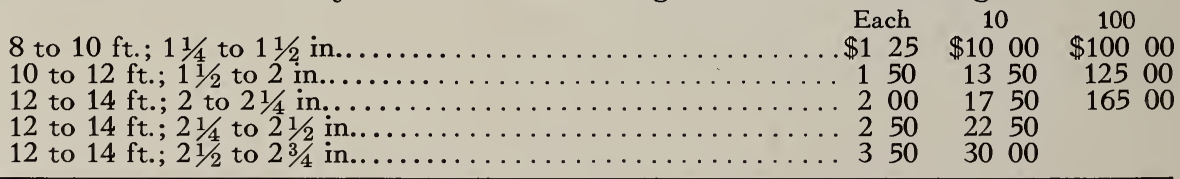




\section{English Elm}

Ulmus campestris

The branches of the English EIm are more compact than the preceding, and it forms a round-topped head; it has many pleasing qualities and is altogether to be highly recommended.

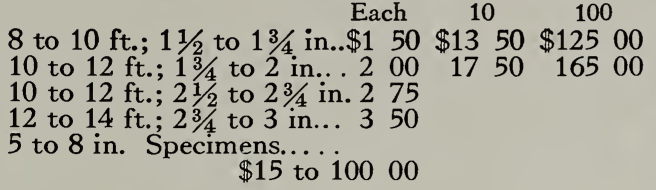

\section{Broad-leaved English Elm}

Ulmus campestris, var. latifolia (major)

Its Iarge, dark green leaves make it distinctive, and, as with other EIms, its rapid growth is desirable.

18 to $25 \mathrm{ft}$; 5 to 8 in.

Each $\$ 25$ to $\$ 10000$

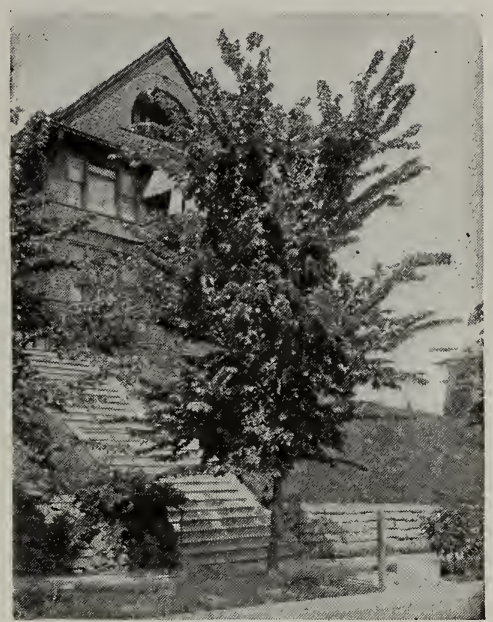

English Elm

\section{Cornish Elm}

Ulmus campestris, var. Wheatleyi

A not-widely-known variety of exceptional merit, forming a pyramidal head of smaIl, dark green leaves; of vigorous growth and clean habits. We highly recommend this tree for more extensive planting on streets and avenues and as a shade tree. In many situations where a tall, narrow, pyramidal-headed tree is required, the Cornish EIm is without an equal; in its younger stages it forms an admirable alternative for the Lombardy Poplar and it has the greatest advantage over the Poplar in that it is a long-lived tree, the foliage is rich, dark green, and it is not subject to the insect pests of the Poplar. By clipping and training it makes one of the best trees for pleached walks or for allees.

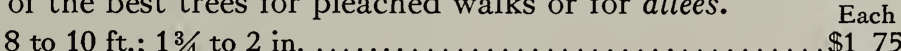

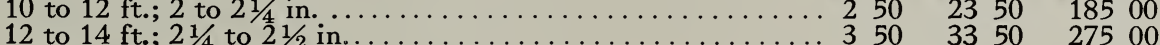

\section{Columnar Wych Elm}

Ulmus scabra, var. Dampieri; syn. fastigiata

With the form, but without the faults, of the Lombardy Poplar, this littleknown tree should receive the attention it deserves for situations where a tall, narrow tree with rich, dark green foliage is desired.

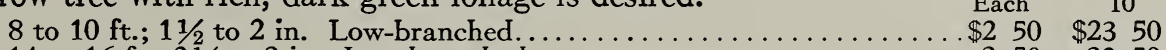

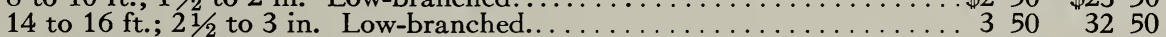

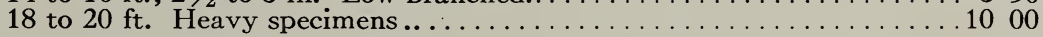

\section{Huntingdon Elm}

Ulmus scabra, var. Huntingdonii

Erect in habit and of vigorous growth, it forms a beautiful shade tree.

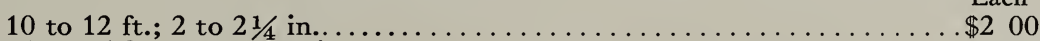

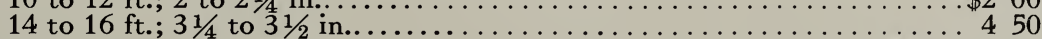

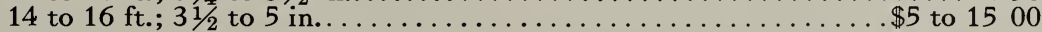

\section{Scotch or Wych Elm}

\section{Ulmus scabra, var. montana}

Forming a spreading, round-topped head, this variety is to be highly recommended for shade-tree planting in any situation. 


\section{How to Care for and Plant Trees}

$\mathrm{O}$

$\mathrm{N}$ ARRIVAL, the trees should at once be unpacked, and if the material cannot be promptly planted, it should be "heeled-in." Dig a trench of sufficient width and depth to accommodate the roots without bending them. In this trench set the trees close together, cover the roots with soil, mounding it up along the line of the trench, so that it will turn off the water in case of heavy rains. This is of special importance where trees must remain heeled-in any length of time. If the trees can be planted at once, the most important point is

The Preparation of the Hole. This should be dug at least one foot wider all around than the spread of the roots of the tree to be set, and in good soil should be from 15 to 24 inches in depth, unless for a very large specimen, when it should be proportionately deeper. In case the soil is not good, a much larger hole should be excavated and filled with good soil. Should the planting space be in a clayey soil, the bottom of the hole should be loosened up; if possible, dig entirely through the clay. If not, dig deep enough to fill in with stone or some loose material that will insure drainage.

KIND of SoIL. We are frequently asked what kind of soil to use and with what to enrich it. Just here we would emphasize the fact that too much care cannot be taken with the preparation of the hole for planting. It is absolutely necessary that the tree be given a quantity of good soil if one would attain satisfactory results. The very best soil obtainable is that from an old meadow where the rich top-soil and sod can be stripped and thrown together. It is always advisable, where much planting is done, to have a compost heap prepared the season previous by putting soil and manure in alternate layers, and have the pile turned two or three times. When either of these kinds of soil is not possible, old thoroughly rotted manure can be mixed with the soil for planting.

When Setring the Tree, take care that all broken portions of roots are cut off in a clean, careful manner; then set the tree, spreading the roots in a natural position, taking care that the small fibers are not twisted or crowded. Fill in with good, fine soil, which should be worked carefully under the roots so that no spaces remain unfilled. Be careful not to plant too deep. The tree will generally show by the soil-mark on its bark the depth at which it stood in the nursery, and it should not be set more than 2 or 3 inches deeper. As the soil is filled in, it should be carefully trampled until quite frrm, and when the hole is filled within an inch or two of the top, the last of the soil should be spread without trampling.

After Planting. As soon as the hole is filled and the tree has been properly and frrmly set, spread over the surface a layer 4 or 5 inches thick of either old or fresh manure. This layer should extend a foot or two beyond the line of the newly filled hole, and this mulching is important, as it will help to hold the moisture; and moisture is, after careful planting, the most important aid to insure success. See also page 16. 


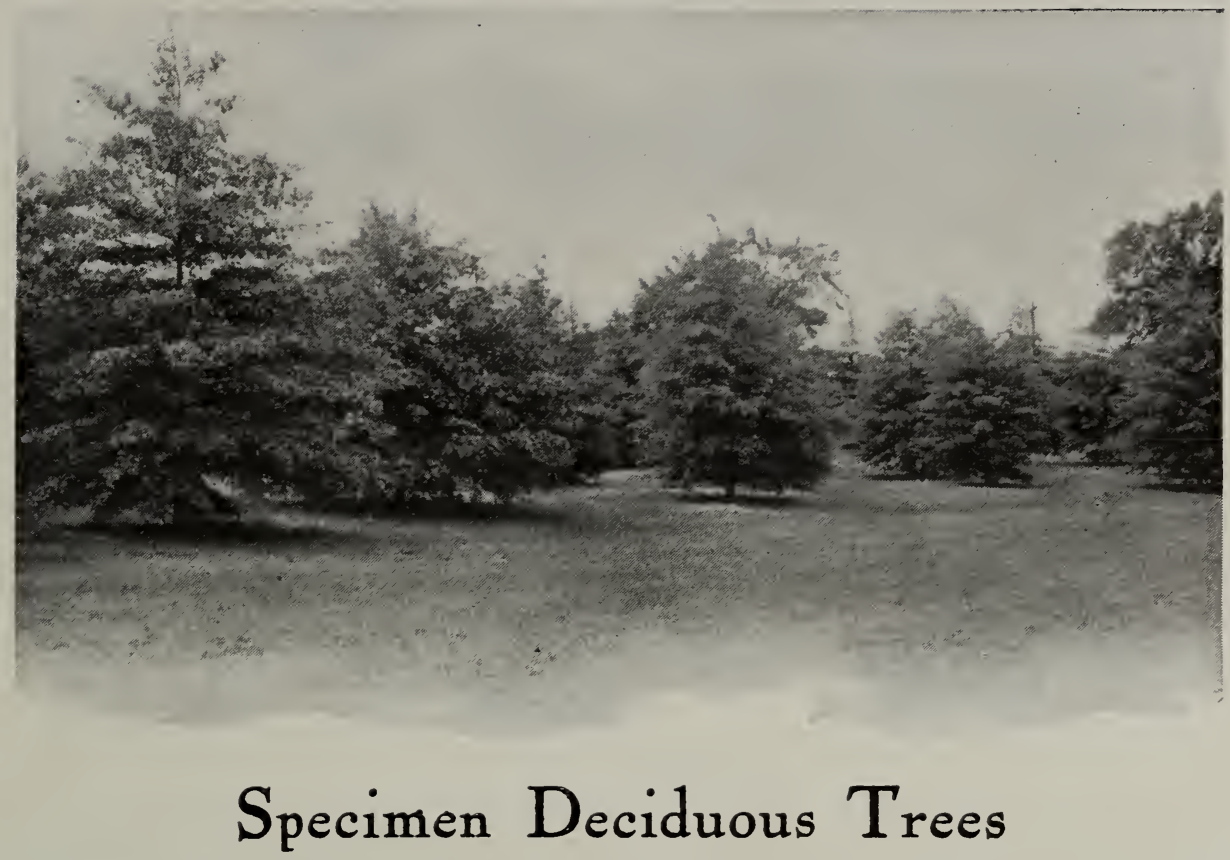

$\mathrm{U}$ NDER this heading will be found many varieties valuable both for their form and coloring and also for their individuality of habit or foliage, as for instance the Cut-Ieaved Maple and Birch, and the Willows. Others, like the English and Mossy-Cup Oaks and Beeches, are valuable for their rarity, while some are worthy of planting both for shade and for their nuts or fruit, as the Walnuts. All have a landscape value for planting singly or in groups.

Taken as a whole, these trees are of medium height and where trees attaining larger size are wanted, or where the added interest of flowers is desired, there will be found many trees under the headings, "Street and Roadside Trees" and "Flowering Trees," which are appropriate to any situation.

\section{Wier's Cut-leaved Silver Maple}

Acer dasycarpum, var. Wieri laciniatum

Its graceful branches, sweeping the ground and its light airy foliage, silvered on the under side, make this tree especially attractive as a tall-growing lawn specimen.

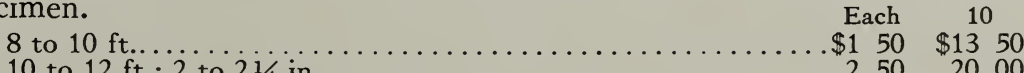

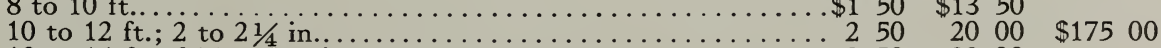

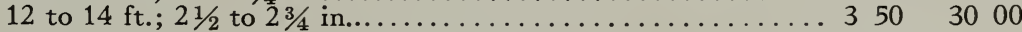

Fern-leaved Alder

Alnus imperialis asplenifolia

A handsome, strong-growing tree, thriving well in moist soil.

5 to $6 \mathrm{ft}$

Cut-leaved Alder

Admirably suited for waterside planting.

Alnus incana, var. laciniata

10 to $12 \mathrm{ft}$

Each 


\section{European White Birch}

Betula alba

A tall, graceful tree for lawn planting, especially attractive when grouped with evergreen trees.

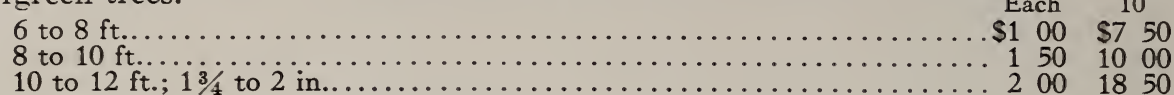

\section{Cut-leaved Weeping White Birch}

A well-known favorite of great beauty.

Betula alba, var. laciniata pendula 8 to $10 \mathrm{ft}$.

\section{Hickory, or Shagbark Hickory}

Each 10

.$\$ 150 \quad \$ 1200$

Slow-growing, but eventually forming a stately specimen, bearing the toothsome hickory nuts which we all remember.

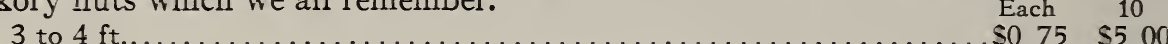

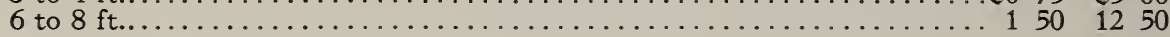

\section{Japanese Chestnut}

Castanea crenata (japonica)

A small tree, forming a dense crown with glossy green leaves; the large nuts are borne when the tree is six to eight years old.

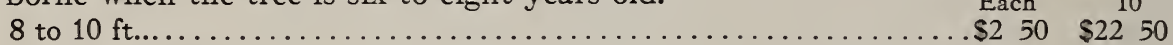

\section{Spanish Chestnut}

Castanea sativa (vesca)

Broad, rounded head and a vigorous grower; the Iarge flowers are very attractive and the nuts are of large size.

4 to $5 \mathrm{ft}$

Each 10

Umbrella Catalpa

Catalpa nana (bungei)

The branches form a flat, globe-shaped, or umbrella-like head, at the top of a

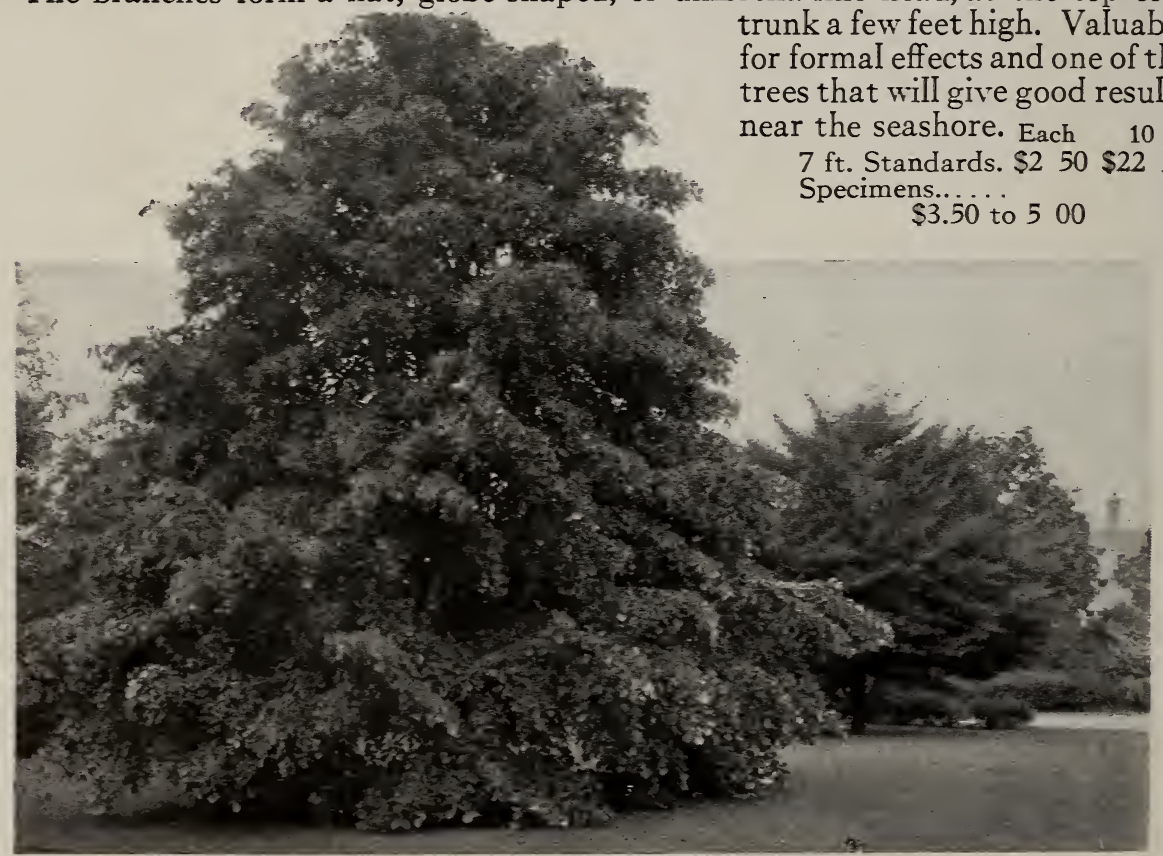

The spreading brancbes of the Englisb Beecb give it an air of distinction 


\section{Common Persimmon}

Diospyros virginiana

Makes a shapely spreading tree on the lawn, bearing pale orange fruits which, until ripe and frosted, are about the bitterest thing in the world. Hardy as far north as Philadelphia and Long Island.

Each 10

5 to $6 \mathrm{ft}$

$\$ 100$

$\$ 750$

\section{European Beech}

Fagus sylvatica

One of the stateliest dome-shaped Iawn trees with branches sweeping to the ground, whose silver-gray leaves in the wind are one of its great attractions. There are many interesting varieties among those given below, as well as the Purple or Copper Beeches, which are found under the heading, "Trees with Colored Foliage." AII are slow-growing, but interesting at all stages of growth. The bright Beech makes one of the best, if not the best of the slower-growing large trees.

When planted closely together in large groups or in a woods planting, the silvery gray trunks with their clean, smooth bark impart a pleasing note of great charm to the fall and winter Iandscape.

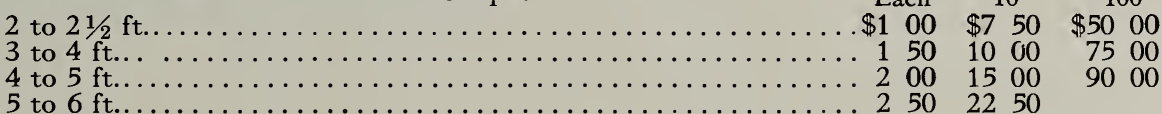

\section{Fern-leaved Beech}

Fagus sylvatica, var. asplenifolia

The leaves are very finely cut, giving an airy appearance to the tree.

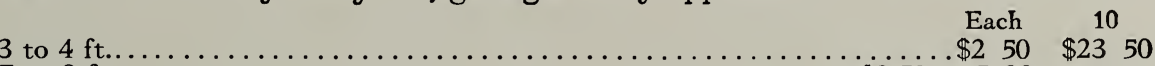

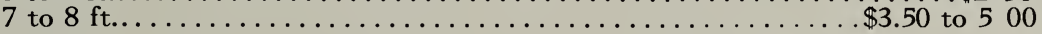

Weeping Beech

Fagus sylvatica, var. pendula

Very effective and ornamental when grouped at the water-side or against a rocky slope.

Each

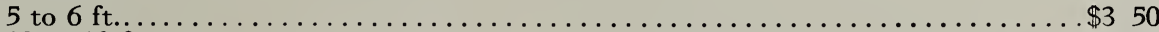

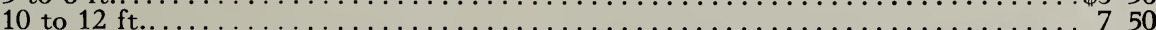

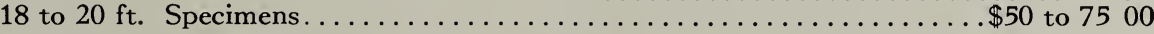

\section{American Black Walnut}

Juglans nigra

One of the grandest and most massive trees when grown in good soil as a specimen; fairly rapid growing; bears large, sweet nuts. $\quad$ Each $\quad \begin{array}{ll}10 & 100\end{array}$

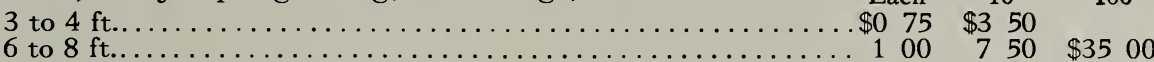

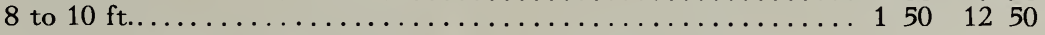

Persian or English Walnut

Juglans regia

A spreading, handsome tree, but not hardy north of the Iatitude of New York; farther south it bears the large meaty nuts of commerce.

3 to $4 \mathrm{ft}$.; $11 / 2$ to $2 \mathrm{in.}$

Each
$\$ 100$

10

apanese Walnut

Juglans sieboldiana

Hardier than the above and valuable for its handsome spreading crown of foliage and for the nuts which are thick-shelled and sweet. One of the desirable lawn trees, in that it furnishes shade and fruit both of a sort that leave little to be desired.

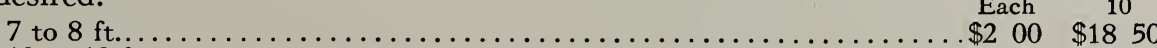

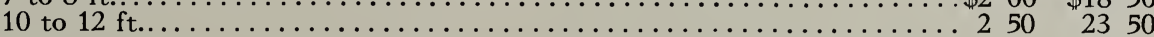

White Mulberry

Morus alba

A native of China, rapid-growing and especially valuable as an attraction for song-birds, on account of the sweet fruit which is borne in abundance. This tree is cultivated in the Orient for feeding silkworms.

7 to $8 \mathrm{ft}$ 


\section{Russian White Mulberry}

Morus alba, var. tatarica.

A low-growing, very hardy type; also valuable for attracting birds as is the foIlowing variety.

6 to $8 \mathrm{ft}$

Each

$\$ 100$

10

Russian Red Mulberry

Morus alba, var. tatarica rubra

Similar to the above; fruit deep reddish purple.

6 to $8 \mathrm{ft} . . \ldots \ldots \ldots \ldots \ldots \ldots 100 \ldots \ldots 70$

\section{Teas' Weeping Mulberry}

Morus alba, var. tatarica pendula

A rapid-growing dwarf tree whose drooping stems form a rounded shower of branches, hanging to the ground; very formal in effect, and by pruning maintains a constant height and size.

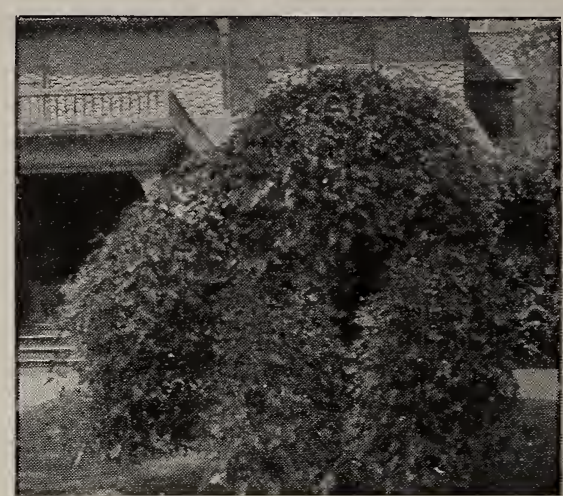

Teas' Weeping Mulberry

Specimens....................................\$2.50 to $\$ 500$

\section{Turkey Oak}

Quercus cerris

Develops into a tall, broadly pyramidal tree of great beauty. It is of rapid, vigorous growth; the dark green leaves are oblong in shape and not deeply indented, quite unlike the Red Oak, for instance.

$31 / 2$ to $4 \mathrm{ft}$. Trans-

Each 10

planted........\$1 $00 \quad \$ 8 \quad 50$

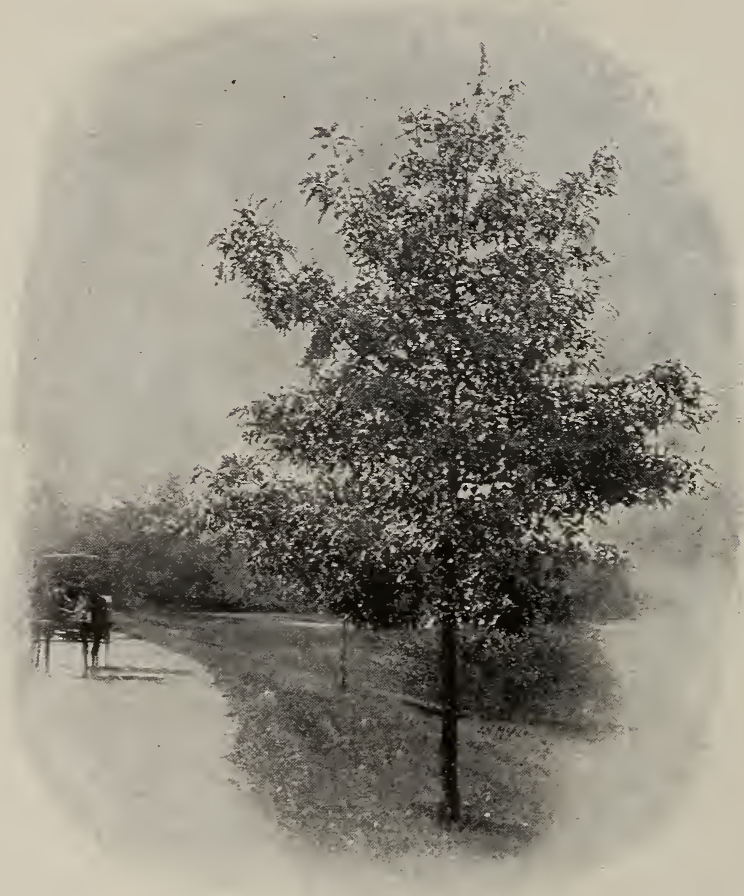

Engizsb Oak
Bur Oak, or Mossy-Cup Oak Quercus macrocarpa

A tree of the same fine habit and form as the Black Oak; tall and wide-spreading, bearing the peculiar acorns which give it its name.

Each 10

6 to $7 \mathrm{ft} . . \ldots \ldots \ldots \$ 175 \$ 1650$

7 to $8 \mathrm{ft} . \ldots \ldots \ldots 2502350$

\section{English Oak}

Quercus pedunculata (robur)

Particularly attractive for its symmetrical, low-spreading head; the leaves, which are smaller and dark green in color, remain green in the fall long after other trees are bare. The late foliage habit of this Oak makes it a desirable tree for screen purposes. The growth is not slow but very dense, the branches having numerous twigs, thus giving a very close head.

Each

10 to $12 \mathrm{ft}$; 2 to $21 / 4$ in... .\$2 50

12 to $14 \mathrm{ft}$; $2 \frac{1}{2}$ to $2 \frac{3}{4}$ in... 350

3 to 6 in. cal. Specimens. .

$\$ 5$ to 2500 
Pyramidal English Oak

Quercus pedunculata, var. fastigiata

In outline it somewhat resembles the Lombardy Poplar, although it does not attain to so great a height, and is slow-growing.

6 to $7 \mathrm{ft}$

Each

$\$ 250$

10

$\$ 2250$

\section{American Mountain-Ash}

Sorbus americana

The clusters of bright orange-red berries, with which this tree is covered in the fall, make it a pretty specimen and interesting in the boundary planting.

7 to $8 \mathrm{ft}$

Each

.$\$ 150$

\section{European Mountain-Ash}

Sorbus aucuparia

Like the above, it is a small-growing tree with finely cut foliage and brilliant scarlet berries in autumn.

Each 10

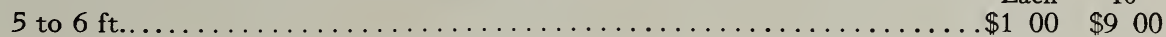

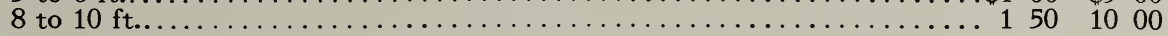

Oak-leaved Mountain-Ash

Sorbus aucuparia, var. quercifolia

Pyramidal in its habit of growth, a smaII, neat Iawn-tree; the oak-like leaves are bright green above and downy beneath.

7 to $8 \mathrm{ft}$

Each 10

.$\$ 250 \quad \$ 22 \quad 50$

Weeping Mountain-Ash

Sorbus aucuparia, var. pendula

Dwarf-growing, its drooping branches covered from midsummer till Iate fall with brilliant red berries.

6 to $7 \mathrm{ft} . \ldots \ldots \ldots \ldots \ldots \$ 250 \quad \$ 2250$

\section{Weeping Willow}

Salix babylonica

A very picturesque tree, universally known and thriving in any good soils; most appropriate for waterside planting; a tall-growing tree with wide-spreading top and massive branches, from which the light branchlets droop in great festoons of foliage.

8 to $10 \mathrm{ft}$

Each

10

\$1 $50 \$ 1250$

\section{Thurlow's Weeping Willow}

Salix elegantissima

Similar to $S$. babylonica in its spreading, drooping form, but hardier in the extreme north; a tall-growing tree.

10 to $12 \mathrm{ft}$............ Each 10

12 to $14 \mathrm{ft} . \ldots \ldots \ldots \ldots \ldots 2250 \quad 2350$

Rosemary Willow Salix incana

A dwarf tree, with symmetrical, round top, slender branches, and pretty narrow leaves.

$\begin{array}{lll}\text { Each } & 10 & 100\end{array}$

2 to $3 \mathrm{ft} \ldots \ldots \ldots \$ 0 \quad 50 \quad \$ 2 \quad 50 \quad \$ 2000$

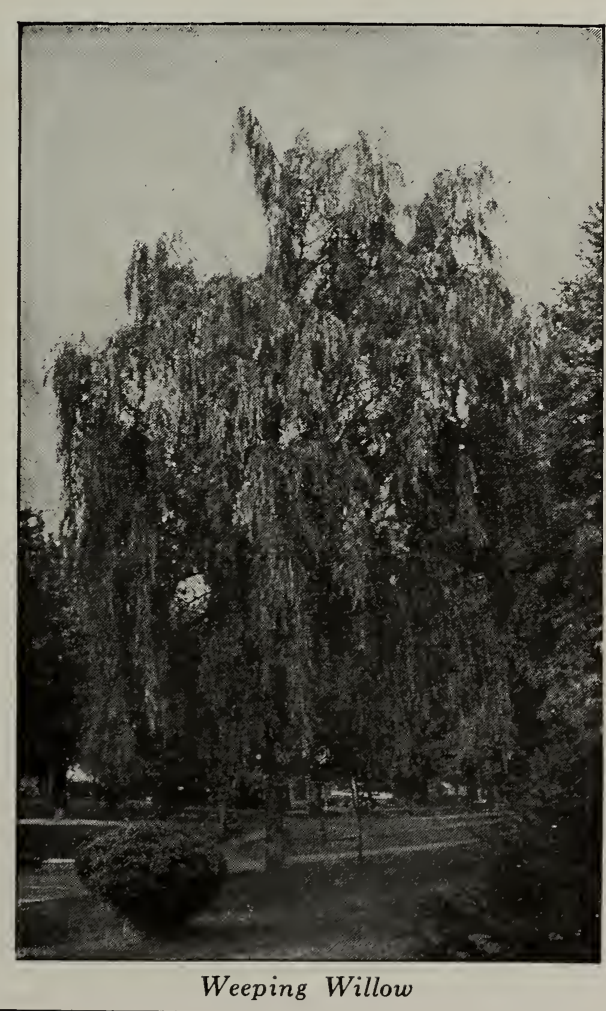

NO CHARGE FOR PACKING 
Golden Willow

Salix lutea

The name refers to its bright, golden yellow twigs, which in winter wonderfully brighten up the landscape; a strong, upright-growing tree with slender branches; one of the finest Willows. Different varieties of Willows may be attractively arranged in groups along the waterside.

Each 10

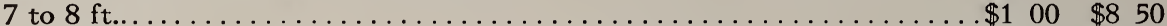

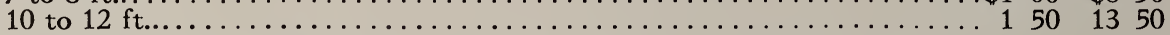

\section{Weeping Golden Willow}

Salix lutea, var. pendula

Its gracefuI, drooping branches, clean appearance, and golden bark serve to make this variety most attractive.

$$
\begin{array}{lll}
\text { Each } & 10 & 100
\end{array}
$$

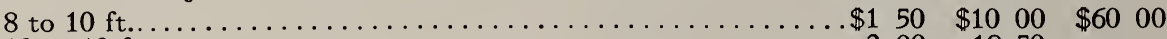

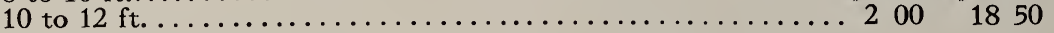

Salmon-barked Willow

Salix vitellina, var. britzensis

The small twigs are salmon-yellow, changing to bronze; a large-growing tree valuable for its winter effect.

Each 10

14 to $16 \mathrm{ft}$

$\$ 250 \$ 2350$

\section{Weeping Sophora}

Sophora japonica, var. pendula

A unique lawn specimen of great beauty, covered in August with clusters of creamy white flowers.

6 to $8 \mathrm{ft}$

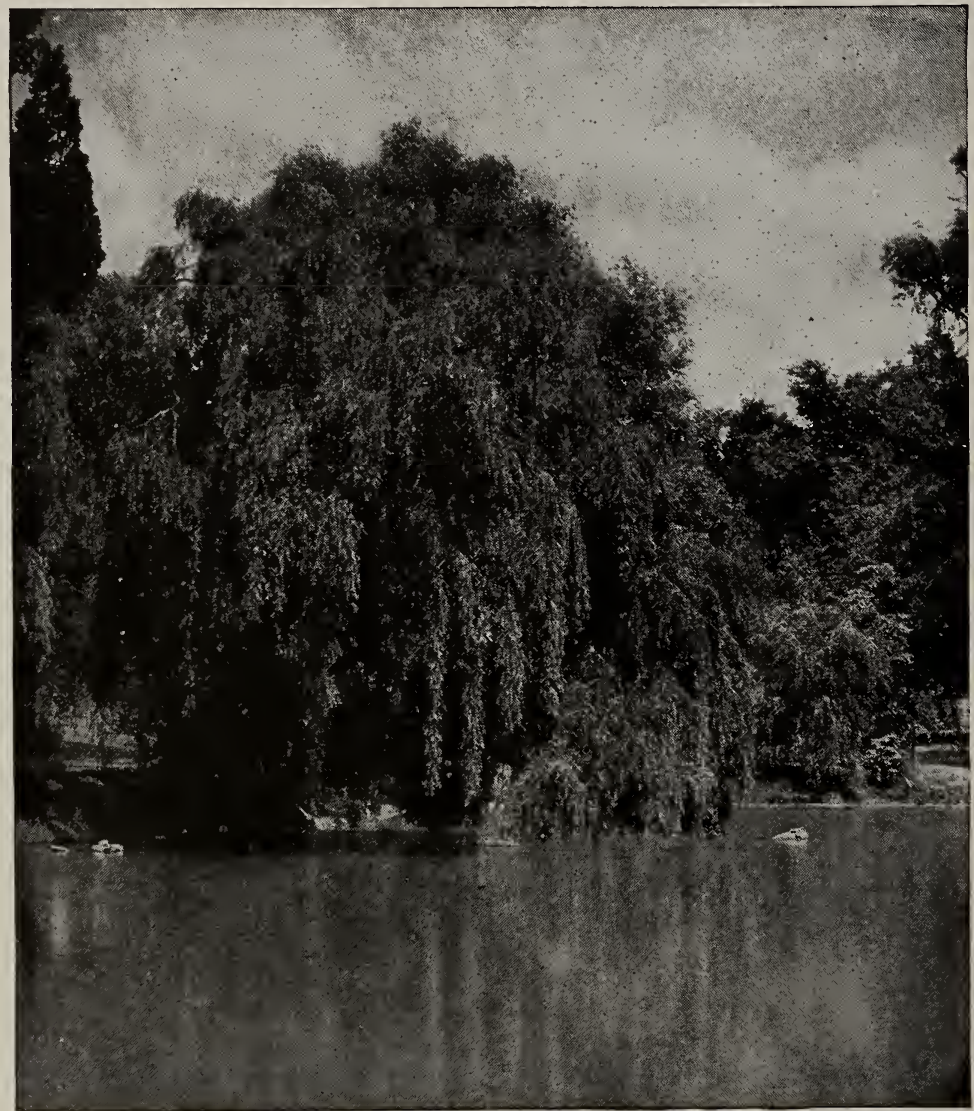

Weeping Willow as a waterside specimen 


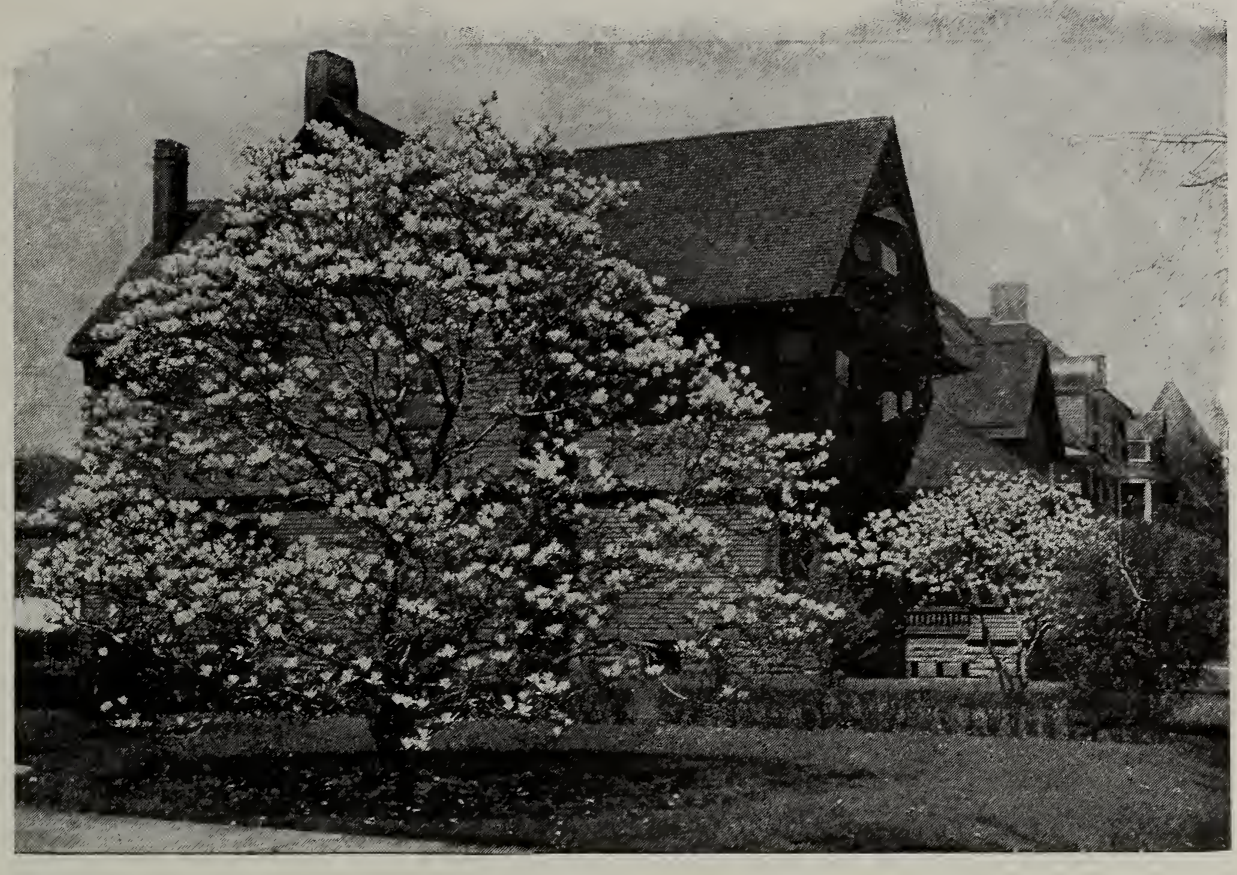

\section{Flowering Trees}

W ITH many advantages of variety of form and foliage, some of these species are adaptable to every sort of situation, whether for screen, border, specimen, or avenue planting. This group of trees possesses the added charm of producing in spring and early summer a wealth of showy blossoms which in many cases are followed by equally attractive bright fruits; especially on this last score are many of them desirable for attracting the song-birds. As this is of interest to so many, we have endeavored to make note of the edible fruits of trees and shrubs throughout this booklet and have arranged a special list of "Trees and Shrubs which attract Song-birds," which we believe will be of interest to our patrons.

\section{European Horse-Chestnut Assculus hippocastanum}

This beautiful, spring-flowering tree makes a fine, large lawn specimen and is equally adaptable for avenue and street planting. Its handsome, dark green leaves possess decided character and produce dense shade; when mature, its lower branches assume a beautiful sweeping habit.

$$
\begin{aligned}
& 8 \text { to } 10 \mathrm{ft} \text {; } 13 / 4 \text { in. . \$1 } 50 \quad \$ 1250 \\
& 10 \text { to } 12 \mathrm{ft} \text {; } 2 \text { to } \\
& 21 / 4 \text { in........... } 250 \quad 1750 \\
& 12 \text { to } 14 \mathrm{ft} \text {; } 2 \frac{1}{2} \text { to } \\
& 23 / 4 \text { in........... } 350 \quad 2750
\end{aligned}
$$

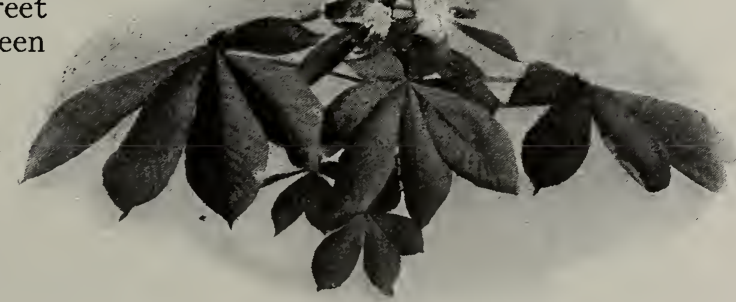

NO CHARGE FOR PACKING

Flowers and foliage of the Horse-Chestnut 


\section{Double White-flowered Horse-Chestnut}

\section{Asculus hippocastanum, var. flore-pleno}

AII the Horse-Chestnuts possess the form and characteristics decidedly adaptable to formal architectural effects; this variety, like the others, is regular in outline and covered in May with large clusters of white flowers.

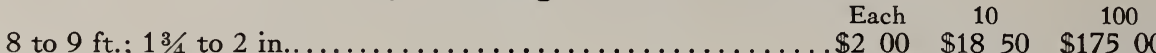

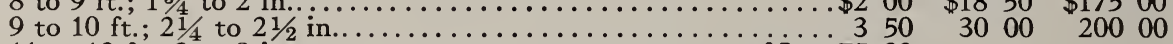

11 to $12 \mathrm{ft} . ; 3$ to 8 in................... $\$ 5$ to 7500

\section{Red-flowered Horse-Chestnut}

AEsculus hippocastanum, var. rubicunda

Does not grow to so large a size as the others, making a fine lawn specimen or a tree for formal effects, though it is not so symmetrical as the double whiteflowered; it is unique in the color of its bloom, and therefore most desirable as a lawn specimen.

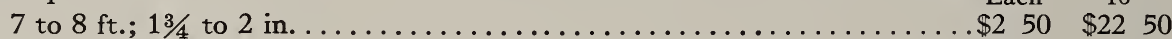

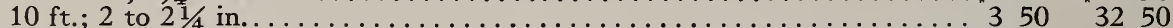

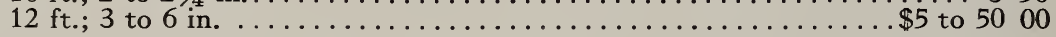

Shad-bush, or Service-berry

Amelanchier canadensis

A tall-growing shrub which eventually assumes the form of an irregular tree and is most attractive at any age, but especially when its white flowers are seen against an evergreen background or in the tall border. Has pretty red berries in summer.

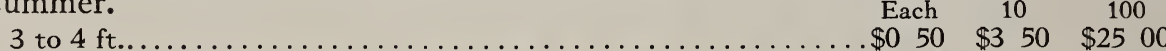

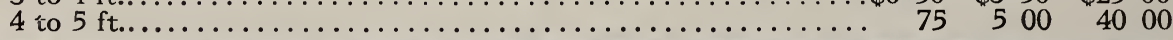

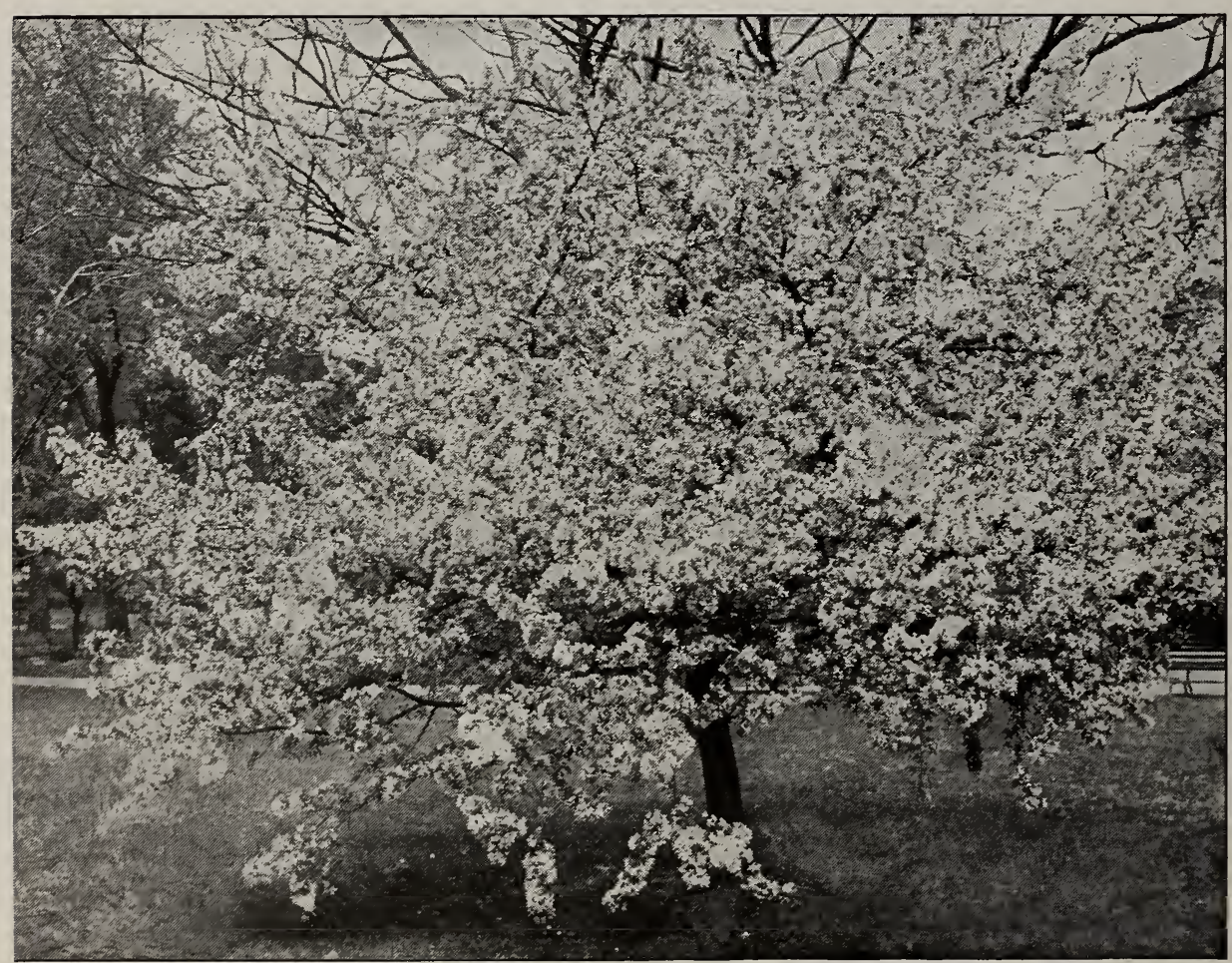

Flowering Cherry (see page 79) 
The broad, round top is covered in early summer with panicles of Iarge, white flowers, followed by pendent, bean-like fruits a foot or more long; large heartshaped leaves. For Iawn or park planting, in groups or singly.

10 to $12 \mathrm{ft}$.

Each 10

$\$ 150 \quad \$ 1000$

\section{Western Catalpa}

Catalpa speciosa

A large-sized, rapid-growing tree of great hardiness, adapted to Iawn or boundary planting. This tree has been used in the Middle West for forest plantings. It has white flowers.

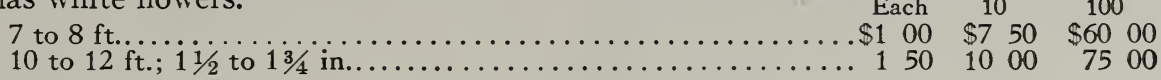

\section{Chinese Cedrela}

Cedrela sinensis

A comparatively recent introduction, somewhat resembling the Ailanthus. Its rapid growth and foliage produce a somewhat tropical effect and it has white flowers in pendulous clusters.

\section{Ornamental Flowering Cherries}

\section{Cerasus}

The famous Flowering Cherries of Japan do not bear fruit, but are grown for their beautiful blossoms alone, which have made them known world-wide. The following varieties may be used with beautiful effect in the garden or for brightening some corner of the shrubbery or boundary planting in early spring. Their beauty and charm is indeed individual and no one should forego the joy of these trees somewhere in the grounds.

CERASUS avium, var. albo-plena. Double White-flowering Cherry. A double, white-flowering variety, making a beautiful smaIl tree for the garden. The flowers are greatly prized for cutting.

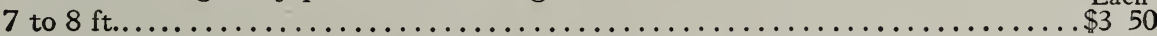

C. avium, var. roseo-plena. Double Pink-flowering Cherry. Double pink flowers, profusely borne in the spring, make this small tree an object of rare beauty.

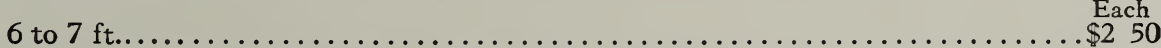

C. avium, var. roseo-pendula. Weeping Pink Japan Cherry. The crooked, drooping branches, covered with pink flowers, produce a strong Japanese effect which especially recommends this little tree for garden use.

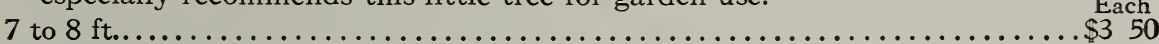

C. sieboldii. The double white flowers, borne in clusters, are beautifully tinted with delicate rose.

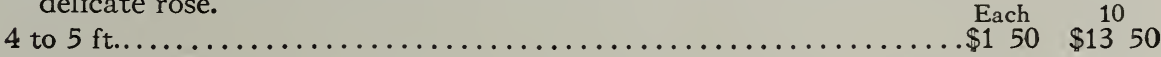

\section{European Bird Cherry}

Cerasus padus

Resembles our native Choke Cherry and is especially valuable for attracting song-birds, which are very fond of its black fruit which follows the white flowers. Plant in boundary or high border.

8 to $10 \mathrm{ft}$

10 to $12 \mathrm{ft}$.

Each

10100

$\begin{array}{llllll}\$ 1 & 00 & \$ 8 & 50 & \$ 65 & 00\end{array}$

\section{Wild Black Cherry}

Cerasus serotina

A rapid-growing, spreading tree, covered in spring with a wealth of white blossoms. The small, black cherries, which ripen over a period of several weeks, attract the song-birds from far and wide. Can be planted on the boundary, as a specimen, or in groups.

Each 10

8 to $10 \mathrm{ft}$.

$\$ 150$

10

NO CHARGE FOR PACKING 
Red-Bud, or Judas Tree

Cercis canadensis

One of the most beautiful and showy flowering trees, distinctive in that the rose-pink flowers appearing in early spring, before the leaves are out, completely

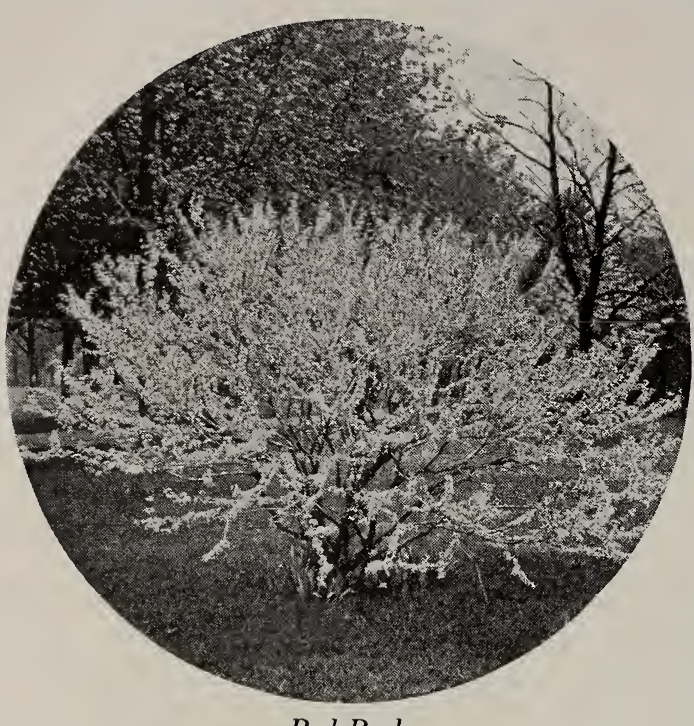

Red-Bud clothe the branches and then, as if not satisfred, appear in little clusters on the large limbs and even on the trunk. It is best planted with a background of evergreens, so that its full beauty is appreciated. It is equally good, however, as a specimen or in groups; low-growing and bushy in its early years.

\begin{tabular}{|c|c|c|c|}
\hline & Each & 10 & 100 \\
\hline $\begin{array}{l}4 \text { to } 5 \mathrm{ft} . . \\
5 \text { to } 6 \mathrm{ft} . . \\
6 \text { to } 7 \mathrm{ft} \text {.. }\end{array}$ & $\begin{array}{r}\$ 050 \\
. \quad 75 \\
. \quad 100 \\
.150\end{array}$ & $\begin{array}{rl}\$ 4 & 00 \\
6 & 00 \\
7 & 50 \\
12 & 50\end{array}$ & $\begin{array}{r}\$ 3500 \\
5000 \\
6000\end{array}$ \\
\hline
\end{tabular}

\section{Yellow-wood}

\section{Cladrastis tinctoria}

A most beautiful lawn tree, the branches and habit of growth producing a distinctly picturesque appearance. The white flowers in early summer have the effect of drooping Wistaria blossoms. Hardy as far north as New England.

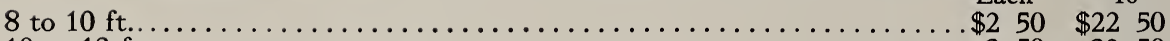

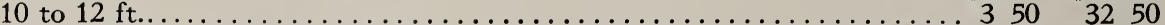

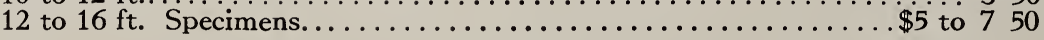

\section{Flowering Dogwoods}

Cornus

It seems as if these graceful trees made a special effort, in the effect of their horizontally flung branches, to spread before us most prettily a profusion of upturned, gorgeous flowers in early spring. There is an indescribable charm about

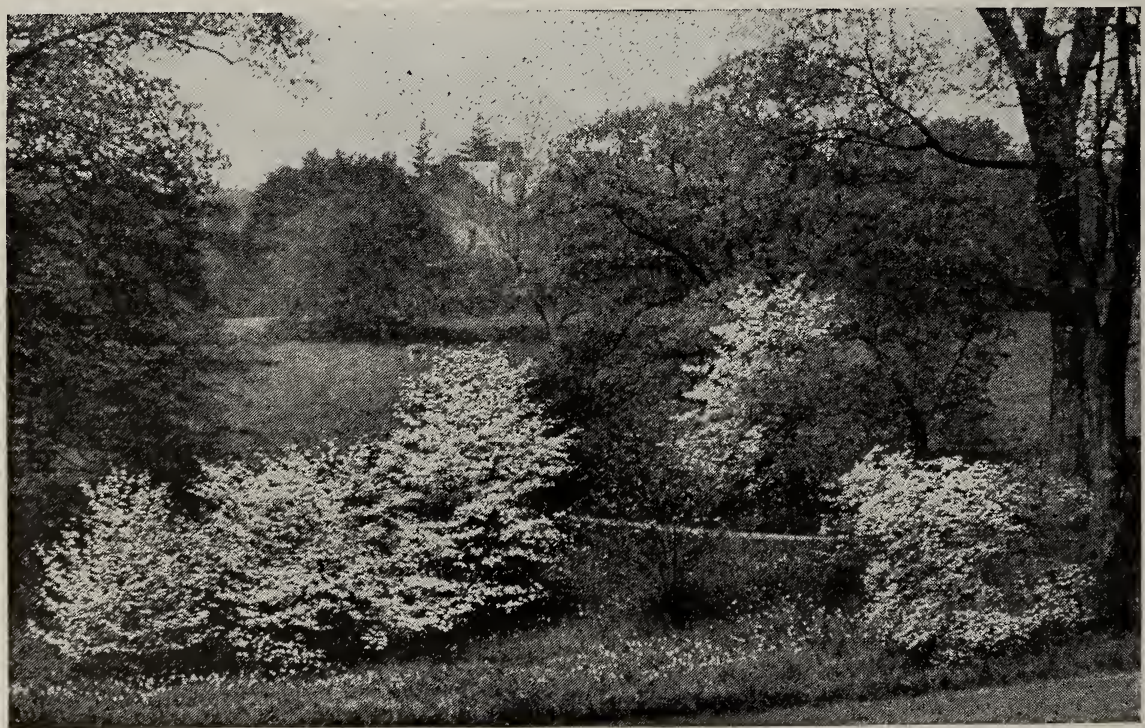

Flowering Dogwood 
the habit of growth and the individuality of the flowers, which makes these slowgrowing trees seem equally at home in formal garden or in great masses in border or naturalesque wood planting.

SEE, ALSO, SHRUBS, PAGE 111.

\section{Alternate-leaved Dogwood}

Cornus alternifolia

A small, bushy tree with horizontal spreading branches. Flowers are creamwhite in spring; the fall coloring is especially fine.

2 to $3 \mathrm{ft}$.

Each
$\$ 035$

10

White-flowering Dogwood

Cornus florida

An upright-growing smaII tree, usually branched quite close to the ground; its wealth of white blossoms is followed by bright scarlet fruits in the fall. Some of the larger sizes may be trimmed to the most charming forms for garden or Japanese effects.

$\begin{array}{lll}\text { Each } & 10 & 100\end{array}$

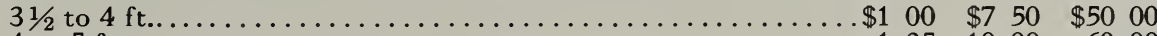

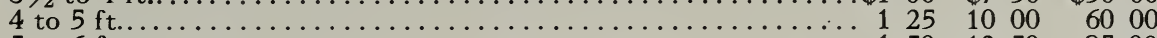

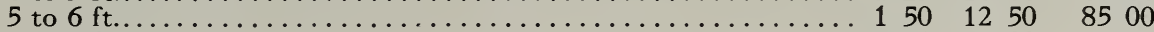

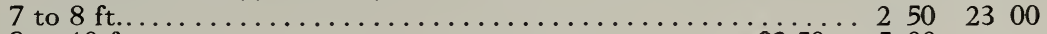

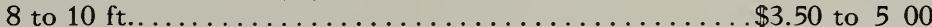

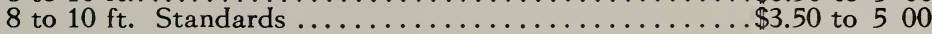

\section{Red-flowering Dogwood}

Cornus florida, var. rubra

This variety surpasses even the above for the beauty of its flowers, which are a beautiful soft pink. Most charming effects are obtained by planting these two varieties in groups together.

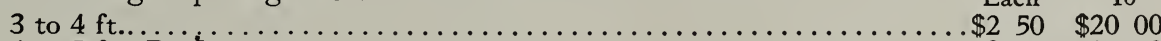

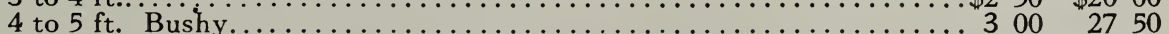

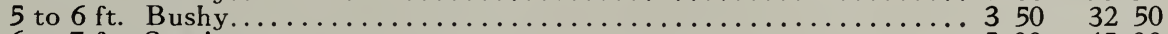

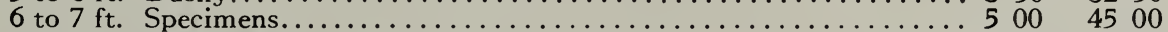

7 to $8 \mathrm{ft}$. Specimens ............................ $750 \quad 6500$

\section{Drooping White Dogwood}

Cornus florida, var. pendula

A rare form in which the graceful drooping branches from the central upright stem produce a most distinctive effect, especially suitable for the garden or as specimens.

10 to $12 \mathrm{ft}$. Rare..................................... \$15 00

\section{Japanese Dogwood}

This unusual type of Cornus represents in Japan the Cornus florida of our own states, differing, however, in that while our American Dogwood carries its fruit in close heads individually distinct, in the Japanese species the berries are united together in a flushed strawberry-shaped mass. It is a bushy, flat-topped tree, about the size of our native Dogwood, but the leaves are smaller and narrower, and the flower-heads are on longer and more slender peduncles. It opposes our native Dogwood, as, blooming about the end of May, it carries its flowers after the tree is in full foliage.

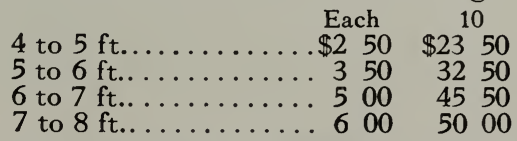

NO CHARGE FOR PACKING

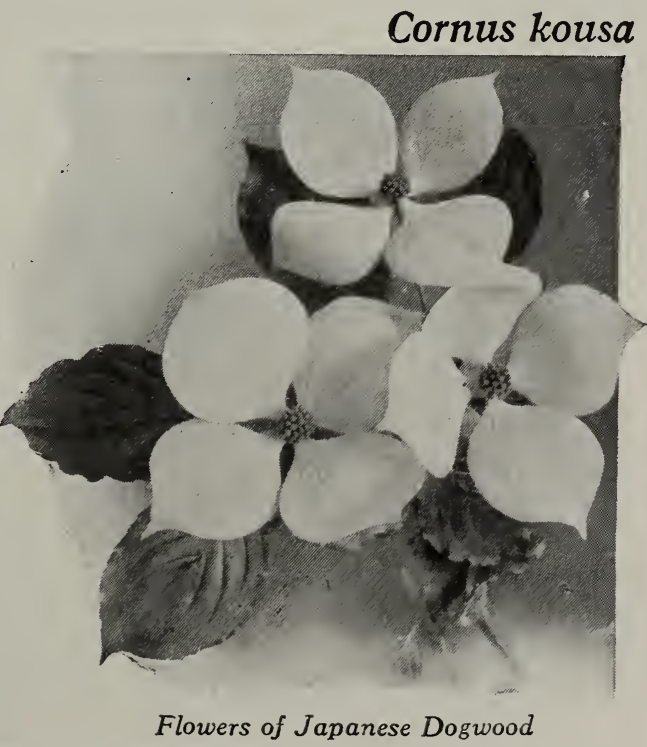

Flowers of Japanese Dogwood 


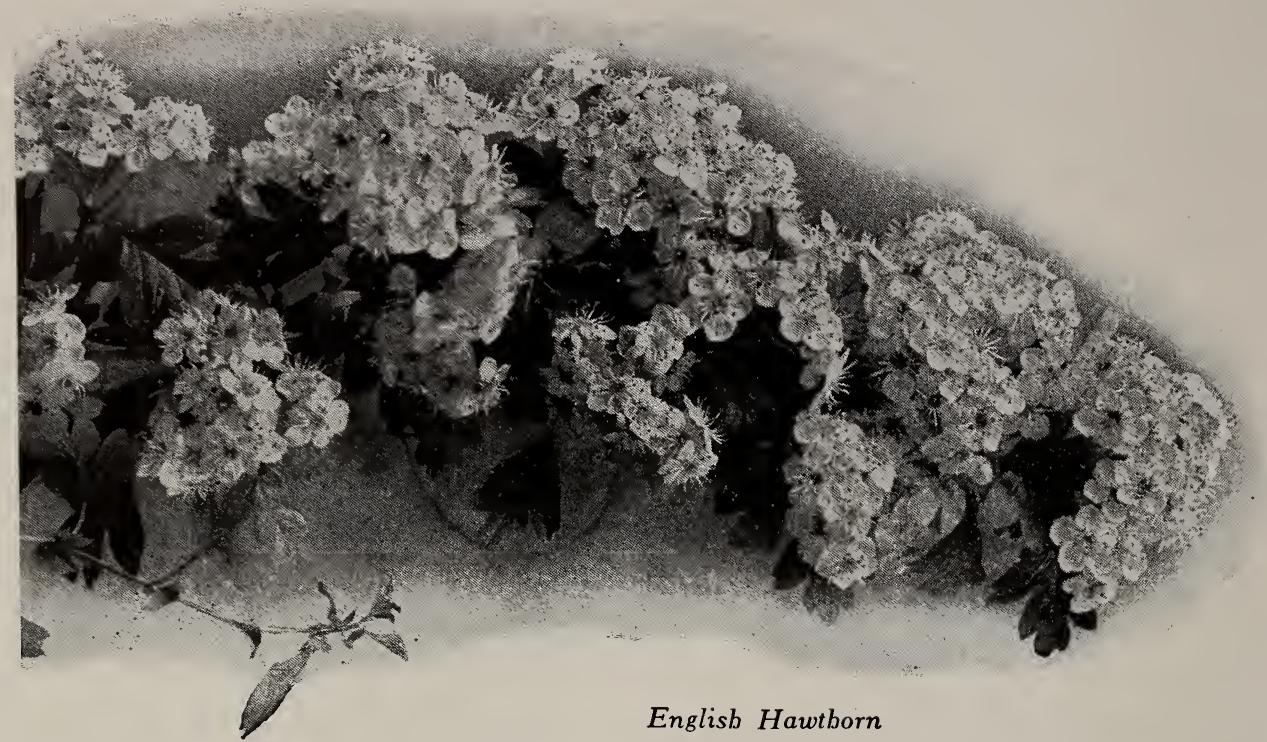

\section{Thorns, or Hawthorns}

Crataegus

These are all low-growing trees, with wide-spreading heads of rather shrubby appearance, and are very useful in the shrubbery border or screen of shrubs, both for their attractive profusion of flowers in May and for the thorn-apples which appear in bright colors in the fall.

The varieties of the English Hawthorn have more of the usual habit of small trees and are useful as Iawn specimens, in groups or in gardens. Many plants of the larger sizes of the other varieties may be trimmed up to form pretty miniature trees for special purposes, but in their early growth they have a bushy habit, making them very valuable in high borders of shrubs.

\section{Carriere's Thorn}

Cratægus carrierei

Becomes a most attractive small tree with pretty white flowers and brilliant orange-scarlet Iarge thorn-apples, which are retained till late in the fall. UsefuI in the high border or as a small specimen on the lawn or in formal work.

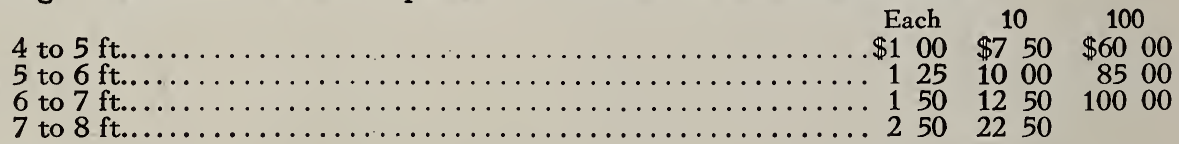

\section{Scarlet Thorn}

Cratægus coccinea

White flowers appear early in May; fruit scarlet in the fall. For the high shrub border.

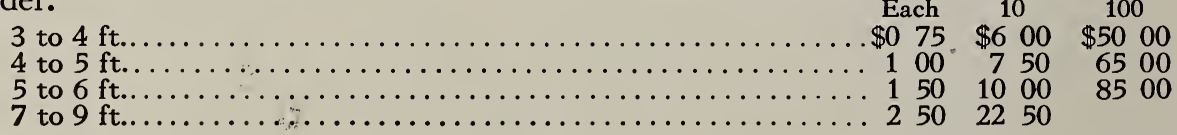

\section{Cockspur Thorn}

Cratægus crus-galli

Small, shrubby growing tree, attractive for flowers and deep crimson fruit in the late summer and fall; well placed in screen or border planting, or makes an excellent hedge, holding its deep green foliage until very late.

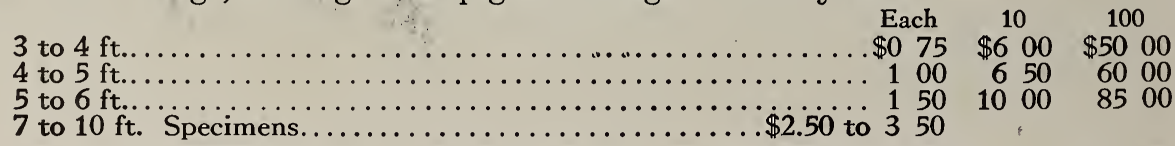


In general effect, similar to the preceding; the fall coloring is especially fine.

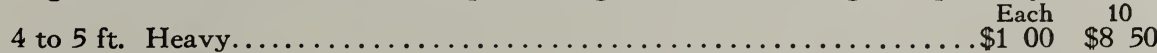

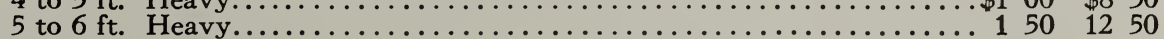

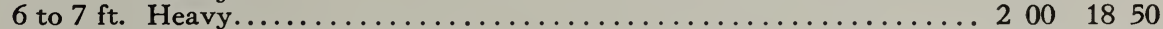

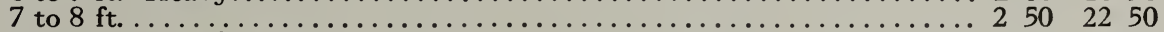

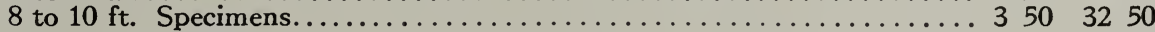

English Hawthorn

Cratægus oxyacantha

This Thorn makes the hedge-rows of England a smother of white in May, and can be used in a like manner here or in the shrub border.

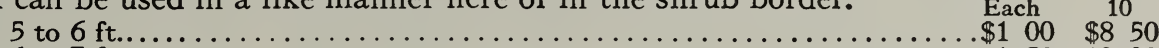

6 to $7 \mathrm{ft}$.............................................. $150 \quad 1000$

Double Pink Hawthorn

Cratægus oxyacantha, var. rosea flore-pleno

This and the following varieties make the finest sort of small specimen trees for any purpose.

3 to $4 \mathrm{ft}$.

$\begin{array}{ll}\text { Each } & 10 \\ \$ 075 & \$ 650\end{array}$

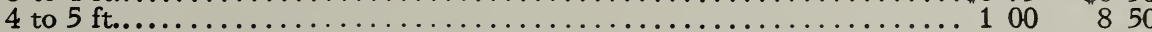

Double White Hawthorn Cratægusoxyacantha, var. alba flore-pleno

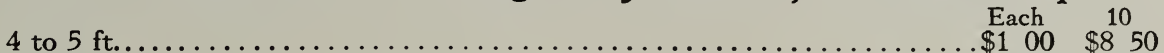

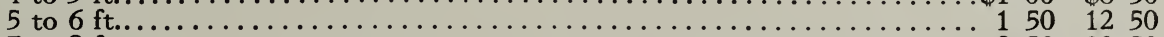

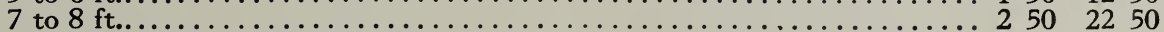

Paul's Double Scarlet Hawthorn

Cratægus oxyacantha, var. coccinea flore-pleno

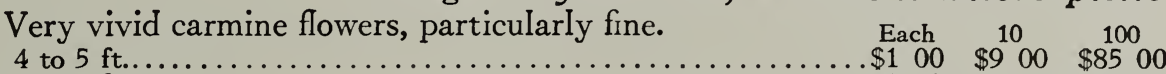

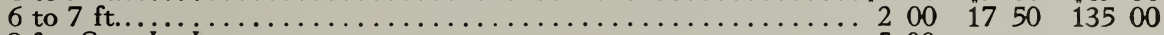

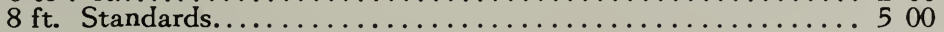

12 to $14 \mathrm{ft}$. Standards.......................... 1250

Red-flowered Hawthorn

Cratægus oxyacantha, var. punicea

Single flowers of deep red. The general form and habit of the tree is the same as C. oxyacantha.

8 to $10 \mathrm{ft}$

Each 10

Double Rose-flowered Hawthorn

Double flowers, almost scarlet. One of the most desirable for generaI planting.

5 to $6 \mathrm{ft} . \ldots \ldots \ldots \ldots . . \$ 150 \quad \$ 13^{\text {Each }} 50$

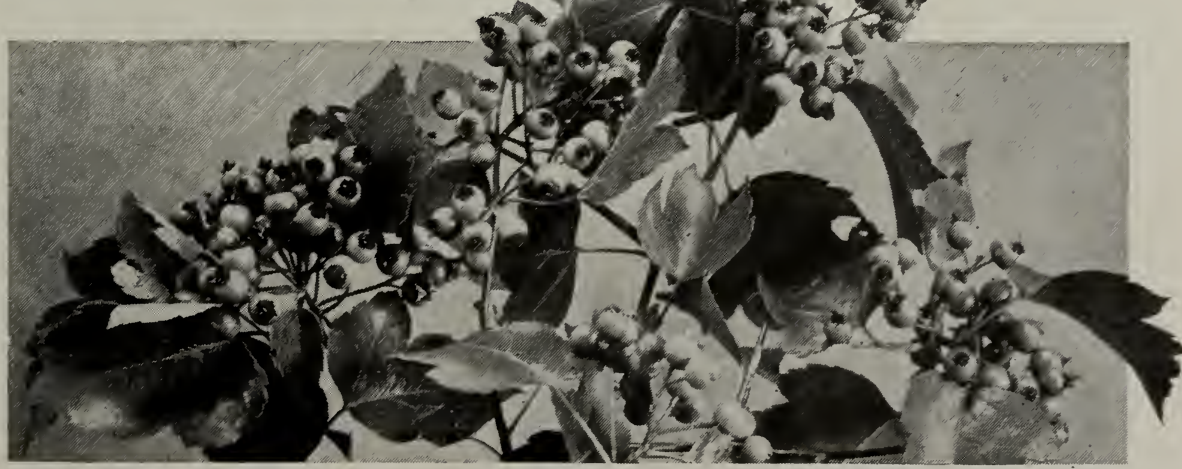

The fruit of the Wasbington Tborn is a blaze of color in autumn

NO CHARGE FOR PACKING 


\section{Golden Chain}

A small tree, covered in June with beautiful racemes of golden yellow flowers, whence its name.

Each 10

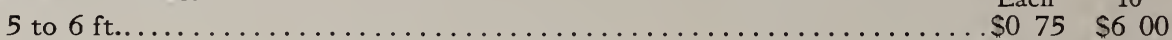

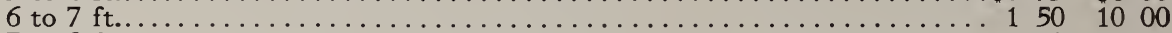

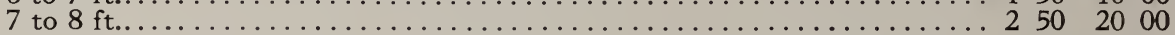

\section{Drooping Golden Chain}

Laburnum vulgare pendulum

A fine garden tree with branches drooping from a straight trunk about 6 feet high.

Each

7 to $8 \mathrm{ft}$. Specimens.

$\$ 5$ to $\$ 1000$

\section{Flowering Ash}

Fraxinus ornus

A small, neat-growing Iawn tree, producing showy, dense racemes of white flowers in early summer.

5 to $6 \mathrm{ft}$...

Each 10

7 to $8 \mathrm{ft}$

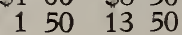

\section{Water Locust}

\section{Gleditschia aquatica}

An airy-leaved, white-flowering tree, thriving in moist places.

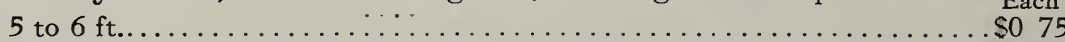

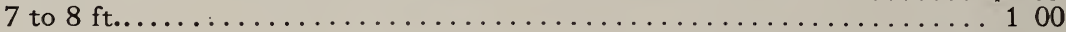

10

\section{Honey Locust}

\section{Gleditschia triacanthos}

This tree has two widely divergent uses, one as a tall stately specimen, the other as a taII hedge, planted closely together and closely clipped, when it becomes impenetrable to man or beast.

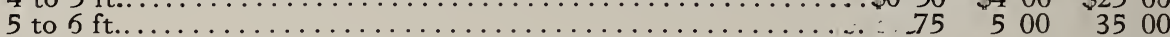

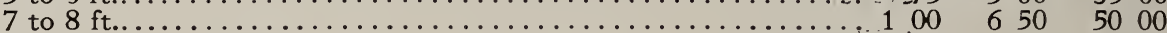

Kentucky Coffee Tree

Gymnocladus canadensis

A picturesque open-headed tree with Iuxuriant, divided foliage; weIl used as a lawn tree, preferably in groups, or in border planting. Each $10 \quad 100$

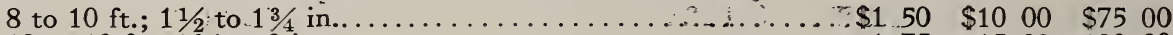

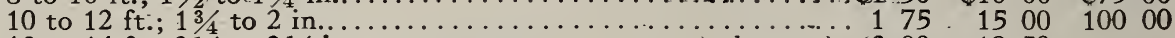

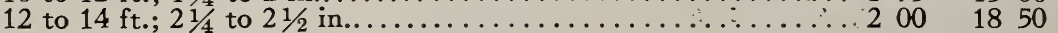

\section{Varnish Tree}

\section{Kolreuteria paniculata}

Its habit is to form a slightly crooked trunk, in which an artist would say, "there is lots of movement," and the finely cut luxuriant foliage and showy yellow flowers give it a good "texture." Admirably adapted to introduce pleasing variety into any grouping or for use as a specimen.

Each 10

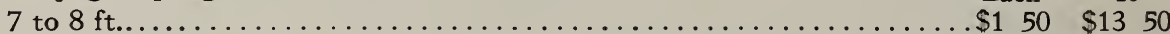

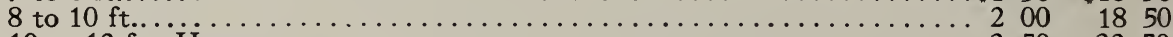

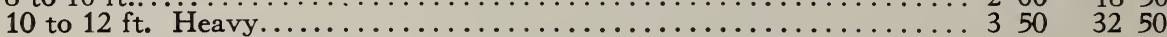

\section{European Sycamore Maple}

Acer pseudoplatanus

Few of the really heavy shade trees give us effective bloom, but the Sycamore Maple is unique in this respect, and its racemes of yellow bloom, borne in great profusion, make it one of the beautiful flowering trees. For roadside planting or as a lawn specimen it has many desirable qualities and we highly recommend it.

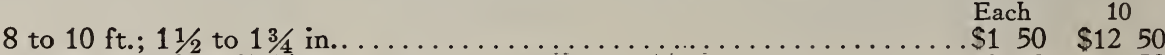

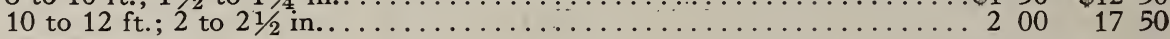




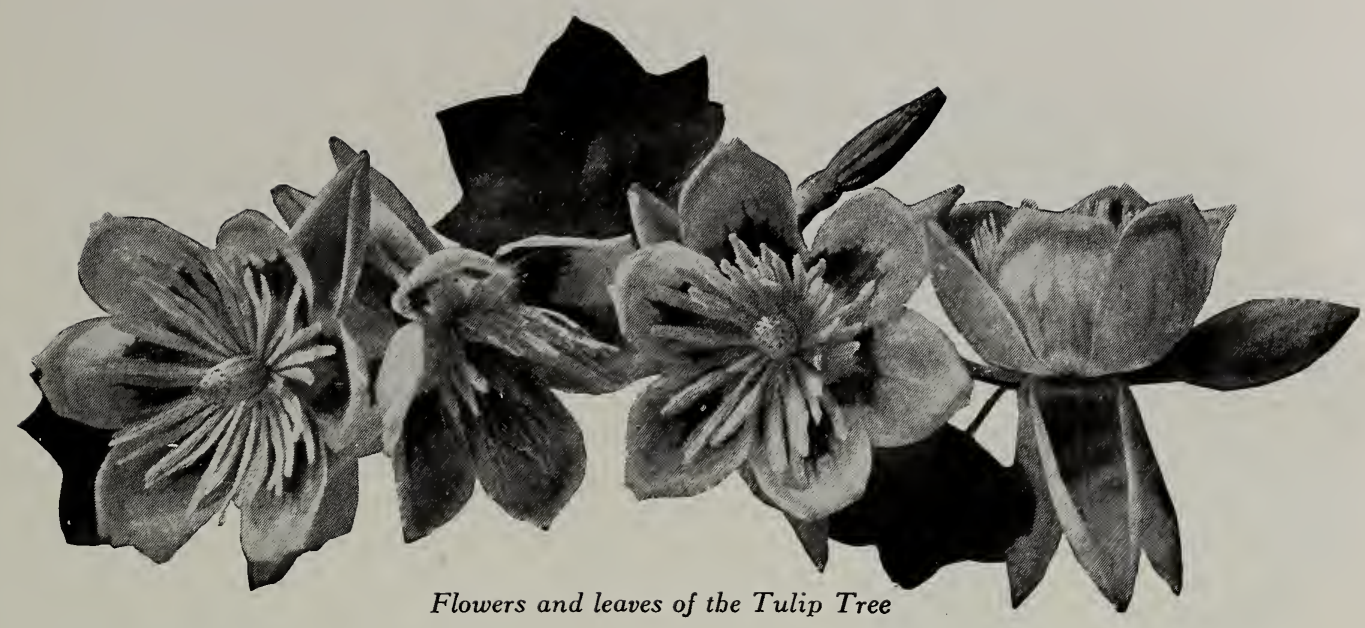

Tulip Tree

Liriodendron tulipifera

On lawns and avenues, or as specimens, this tall, stately tree is most fitting, the large, tulip-like, yellow flowers adding a pleasing note to the rich glossy foliage.

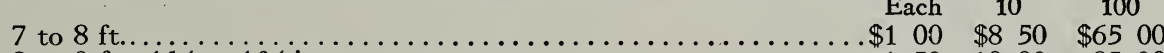

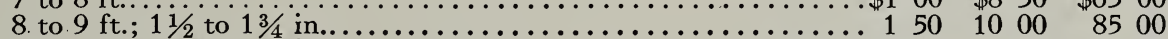

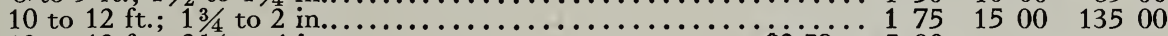

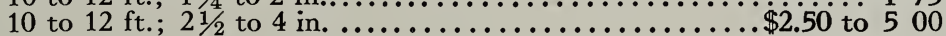

\section{Tree Magnolias}

Magnolia

We have grouped under the heading, "Flowering Trees," those varieties which attain the size of large trees, and under the heading of "Shrubs for Early Spring Effect" will be found other varieties which have more the form of large-growing shrubs or very irregular small trees.

SEE, ALSO, SHRUBS, PAGE 105.

Cucumber Tree

Magnolia acuminata

Adaptable to any position where a tall, broad-spreading tree of good size is required. The greenish yellow flowers are followed by coral-colored seed clusters.

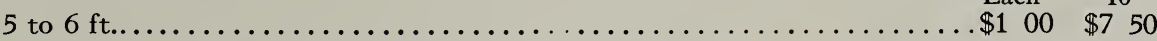

Yulan Tree

Magnolia conspicua (yulan)

From Japan and China, and covered in spring with sweet-scented flowers 6 inches or more across. It is hard to imagine a more showy specimen tree.

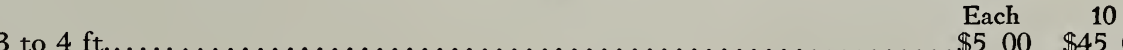

Purple Magnolia

Magnolia hypoleuca

This variety and the following are introductions of great beauty from Japan, on account of their gorgeous flowers and clean, attractive foliage. If trained to a single stem it makes a satisfactory avenue tree.

Each 10

5 to $6 \mathrm{f}$

.$\$ 3 \quad 50 \quad \$ 32 \quad 50$

Japanese Magnolia

Magnolia kobus

One of the hardiest. of the early-flowering species, and one of the smallergrowing, tree forms, with low, dense, much-branched head. It is much more free in flowering than most of the tree-type Magnolias.

Each 10

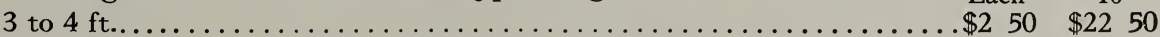

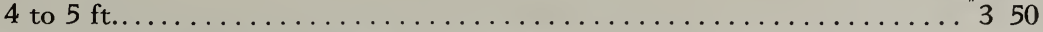

NO CHARGE FOR PACKING 


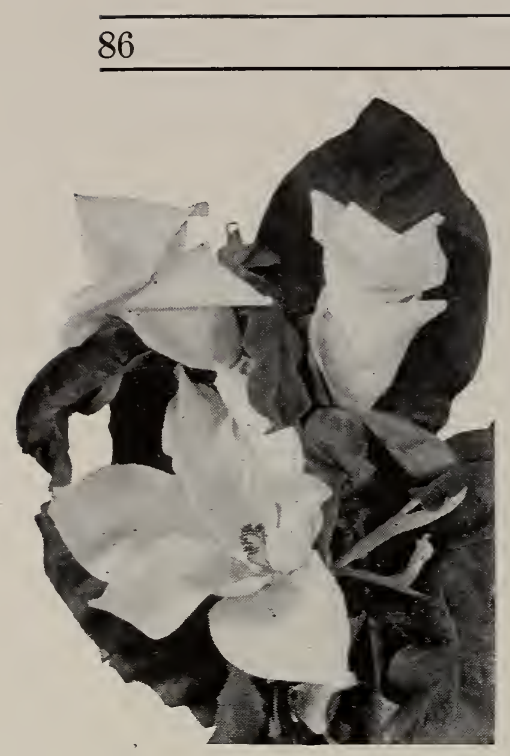

Flowers and leaves of the Great-leaved Magnolia
Flowering Trees

\section{Great-leaved Magnolia}

Magnolia macrophylla

Hardy as far north as Philadelphia and distinctive for the size of its leaves, which are often more than 2 feet long, and for its creamy white flowers nearly a foot across. A symmetrical tree with wide-spreading branches.

Each

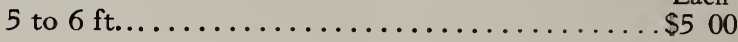

\section{Umbrella Tree}

Magnolia tripetala

The leaves and flowers vie with the above for size and beauty. This is often used for avenue planting as it makes a specimen second only to M. acuminata for shade purposes.

6 to $7 \mathrm{ft}$..

Each

10

7 to $8 \mathrm{ft}$.

$\$ 100$

$\$ 750$

8 to $10 \mathrm{ft}$

250

50

Lily-of-the-Valley Tree

\section{Oxydendrum arboreum (Andromeda} arborea)

The most dazzling effects in the fall foliage, in tones of deep red and scarlet, make this tree of great merit, especially coupled with the fact that it produces in spring the most charming clusters of white flowers, resembling Liliesof-the-Valley, against the dark green leaves. Use in border, in groups, or as lawn specimens.

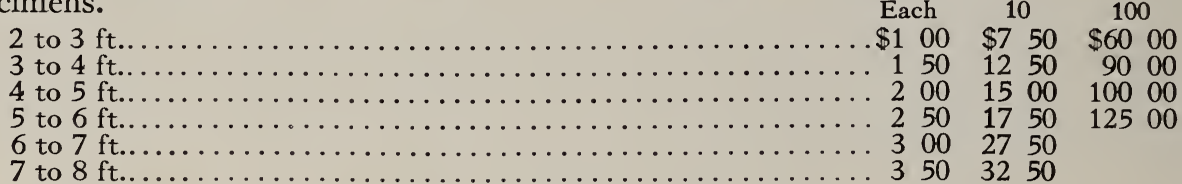

Double White-flowering Peach Persica vulgaris, var. albo-plena

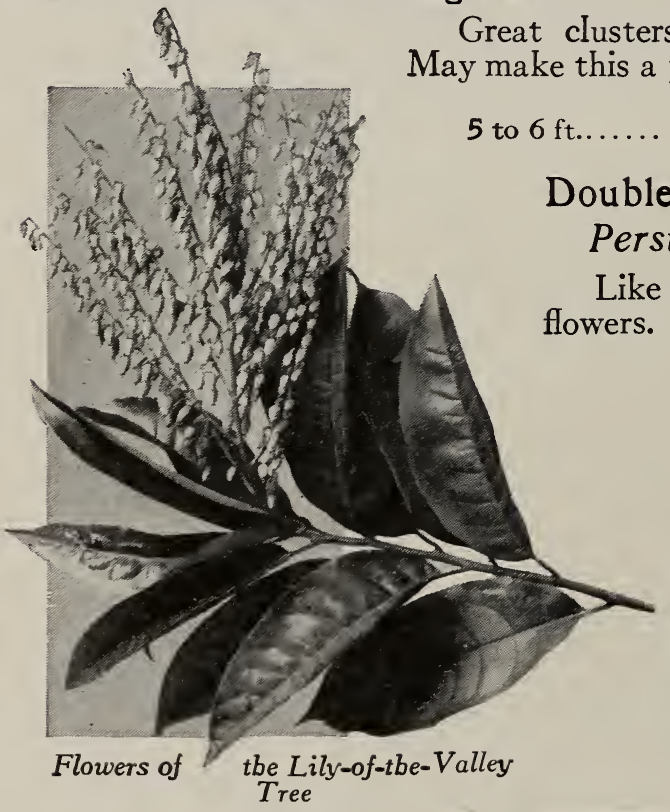
Great clusters of delicate, double, white flowers in May make this a pretty tree for specimen or border.

5 to $6 \mathrm{ft}$

Each 10 $\$ 100 \quad \$ 750$

Double Red-flowering Peach

Persica vulgaris, var. sanguinea plena

Like the above, but with handsome colored 5 to $6 \mathrm{ft} . \ldots \ldots \ldots \ldots \ldots 100 \quad \$ 750$

\section{Persian Iron Tree}

Parrotia persica

A charming, little dwarf tree forming an oval head from the ground, with smaIl dark green leaves which in the autumn turn to a brilliant yellow and crimson. The flowers are distinctive with purple, pendulous stamens. It is very rare, and thrives best in welldrained soil.

Each 10

5 to $6 \mathrm{ft} . \ldots \ldots \ldots \ldots \ldots \$ 30 \quad \$ 3250$ 


\section{Empress Tree Paulownia imperialis}

Large heart-shaped leaves and great violet flowers express the distinction of this tree, which in the North should have protection from inclement winds.

Each 10

10 to $12 \mathrm{ft} . \ldots \ldots \ldots \ldots \ldots \ldots \ldots \ldots 250 \ldots$

\section{Flowering Plum}

\section{Prunus triloba}

A small formal-looking tree with pretty white flowers.

Each 10

3 to $4 \mathrm{ft}$

$\$ 075$

$\$ 500$

\section{Ornamental Flowering Crab-Apple}

Pyrus (Malus)

These include some of the most ornamental, flowering, small trees, literally covered in spring with a wealth of fragrant flowers of rare charm. They are very hardy, and may be planted as attractive specimens alone, or in groups, or again, in the high border or boundary planting; for trees in the garden they are unsurpassed. The flowers of the double-flowered sorts are especially fine for cutting. Some varieties have pretty, little orange or yellow crab-apples in the faIl. The following varieties are the best for general garden or border planting.

\section{Siberian Flowering Crab}

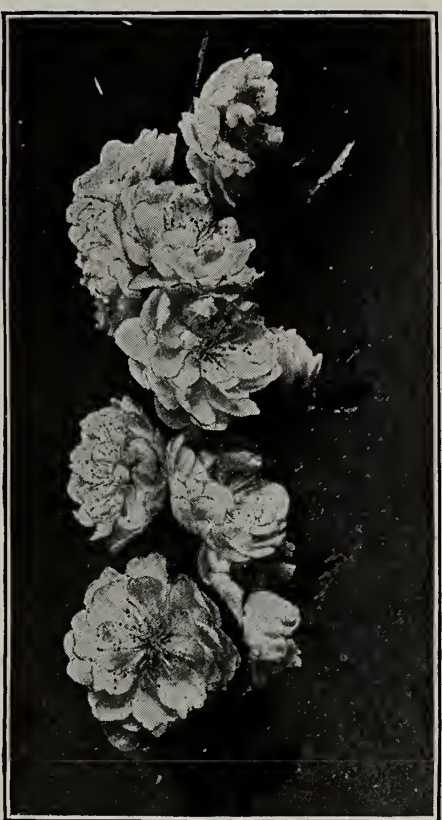

Blossoms of the Flowering Peach (see page 86 )

Pyrus baccata

Fairly symmetrical round head; flowers white or tinted with pink, followed by yellow fruit the size of a cherry. A tree of free growth and robust habit, especially desirable for hillside planting.

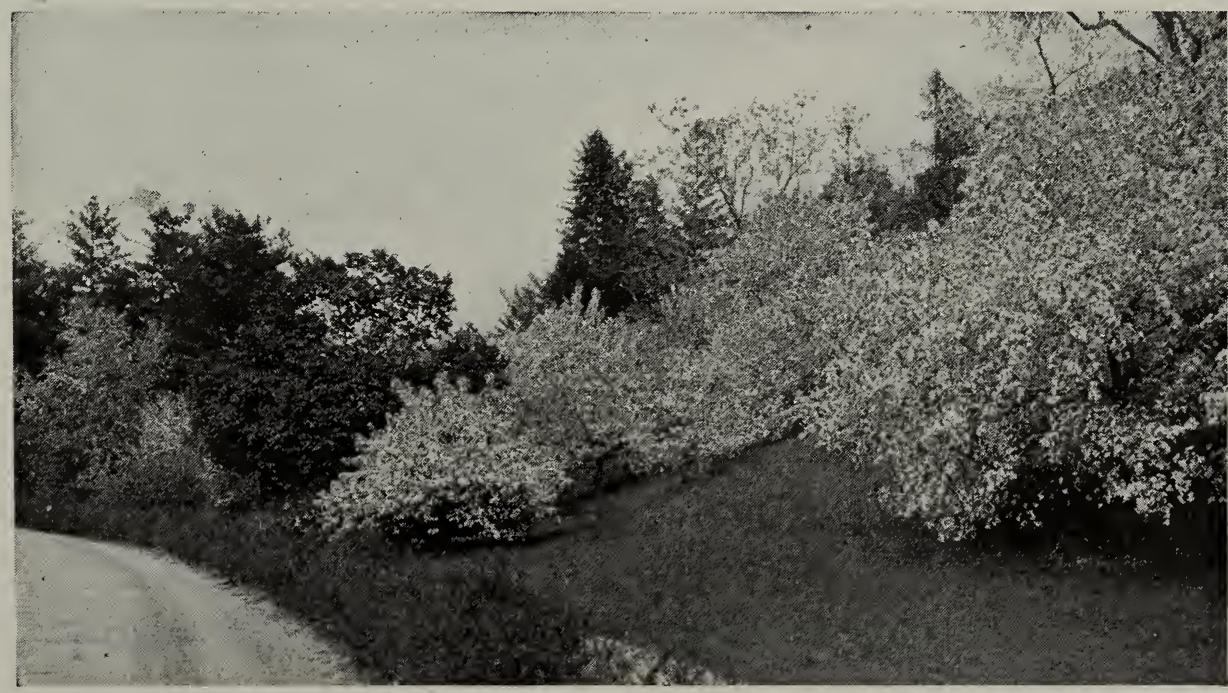

A billside in the Arnold Arboretum, which is a mass of pink and white when the Flowering Crabs are in bloom 
Sweet-scented Crab

Very fragrant, sweet-scented flowers; spreading, symmetrical head.

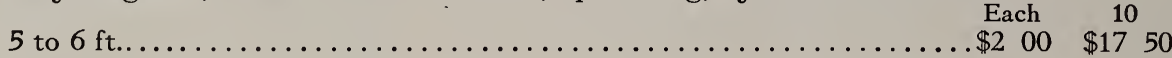

Flowering Crab

Pyrus floribunda

A native of Japan, producing a profusion of rose-colored flowers followed by small red fruits.

Each 10

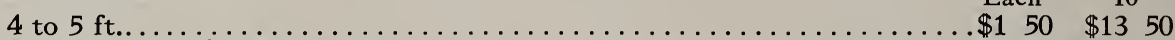

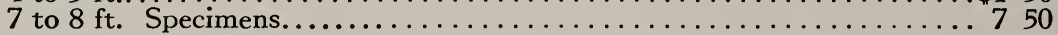

Red-flowered Crab

Pyrus floribunda, var. atrosanguinea

Very rich, rose-red flowers make this variety distinctive in its beauty.

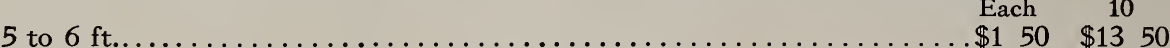

Bechtel's Double-flowering Crab

Pyrus ioensis, var. Bechtelii

Flowers Iarge and very double; of more dwarf growth than some of the other varieties.

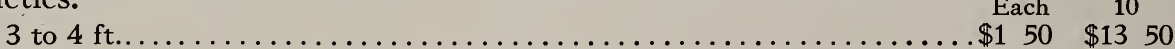

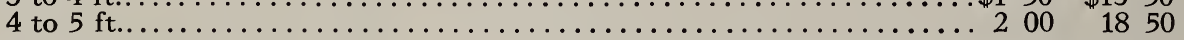

\section{Parkman's Crab}

Pyrus halliana (parkmanii)

Beautiful, semi-double, rose-colored flowers.

Each 10

4 to $5 \mathrm{ft}$.

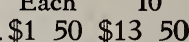

Double-flowering Crab

Pyrus floribunda, var. Scheideckeri

One of the most beautiful smaII trees, with its deep rose-colored blossoms.

5 to $6 \mathrm{ft}$ Each 10

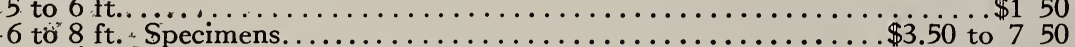

Chinese Double-flowering Crab

The flowers, when in the bud, are coral-red, unfolding a lighter pink.

Pyrus spectabilis 5 to $6 \mathrm{ft} . \ldots \ldots \ldots \ldots \ldots \ldots \ldots \ldots+\ldots 150 \quad \$ 1350$

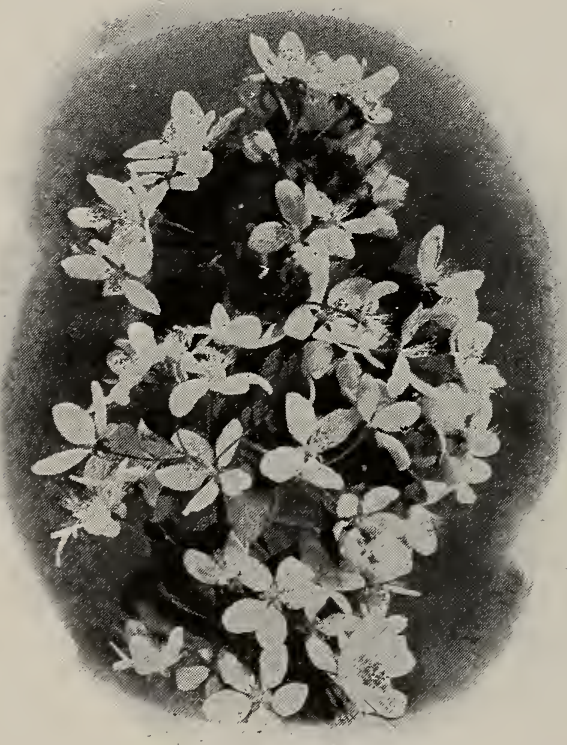

Cbinese Flowering Crab
Pyrus toringo

Dwarf Crab

Very dwarf and especially profuse in its white or pinkish flowers. $\quad$ Each 10

$21 / 2$ to $3 \mathrm{ft} \ldots \ldots \ldots \ldots \ldots \ldots \ldots \ldots \ldots \ldots \ldots \ldots+\$ 1350$

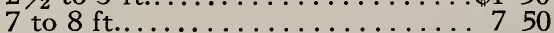

Black Locust

Robinia pseudacacia

The general habit of this rapid-growing tree is in the form of a tall, rugged-looking trunk, surmounted by a feathery crown. Handsome white, sweet pea-like flowers, very sweet-scented.

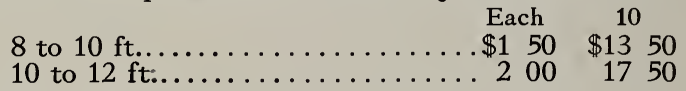

\section{False Camellia}

Stuartia pseudo-camellia

A slow-growing, small tree, with white flowers of rare beauty, resembling a camellia blossom; for garden use; very rare. Each 8 to $12 \mathrm{ft}$. Specimen.............. $\$ 1000$ 


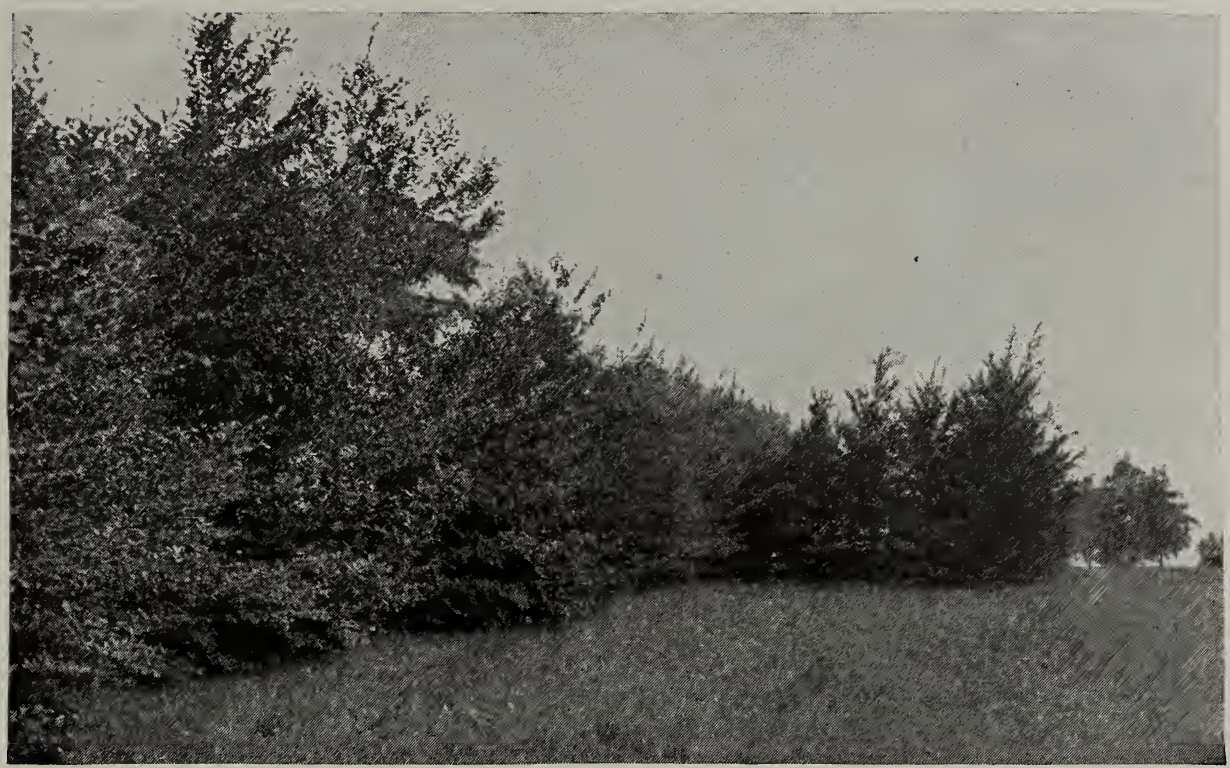

A good screen composed of various varieties of Deciduous Trees

\section{Deciduous Trees for Screens and Windbreaks}

$\mathrm{B}$

Y PROPERLY planting trees of quick-growing varieties in combination with slower-growing, more permanent sorts, it is easily possible in a few years' time effectively to blot out objectionable views which may mar the outlook from house or lawn, at the same time by planting flowering trees, evergreens, or shrubs on the lawn side, producing an added attractive landscape feature.

The trees, found in this category, comprise varieties which are valuable for the purpose, on account of their quick-growing qualities, as the Birches and Poplars, or for the charm of gorgeous fall coloring, as the Tupelo or Sassafras. The admixture of Iong-lived trees and flowering sorts with this group is advisable. In any mass planting of trees the quickest and most satisfactory results are obtained when the spaces between the trées are planted with an undergrowth of spreading shrubs, which protect the ground from drying out by sun and wind. See also page 139 .

For your greater convenience we have arranged these trees for screens and windbreaks in two groups, the one comprising the tall-growing sorts, and the other, those of medium height.

\section{GROUP I • TALL-GROWING}

\section{Box Elder, or Ash-leaved Maple}

Acer negundo

One of the most rapid-growing trees for windbreaks or screens, but short-lived and should be planted in combination with longer-lived species.

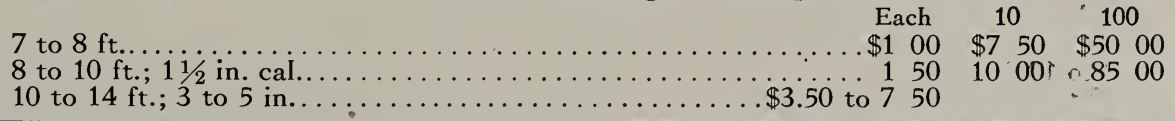

NO CHARGE FOR PACKING 


\section{Striped Maple}

Acer pennsylvanicum

Most interesting on account of the trunk and branches being striped with pale gray lines on the green bark. Very appropriate for planting along the edge of the woods.

Each 10

4 to $5 \mathrm{ft}$ $\$ 100 \$ 850$

\section{Mountain Maple}

Acer spicatum

In form like a very strong, high shrub and valuable in screen plantings.

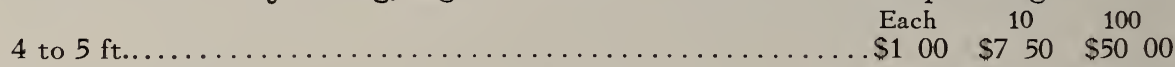

\section{European or Black Alder}

A vigorous, rapid-growing tree for moist places.

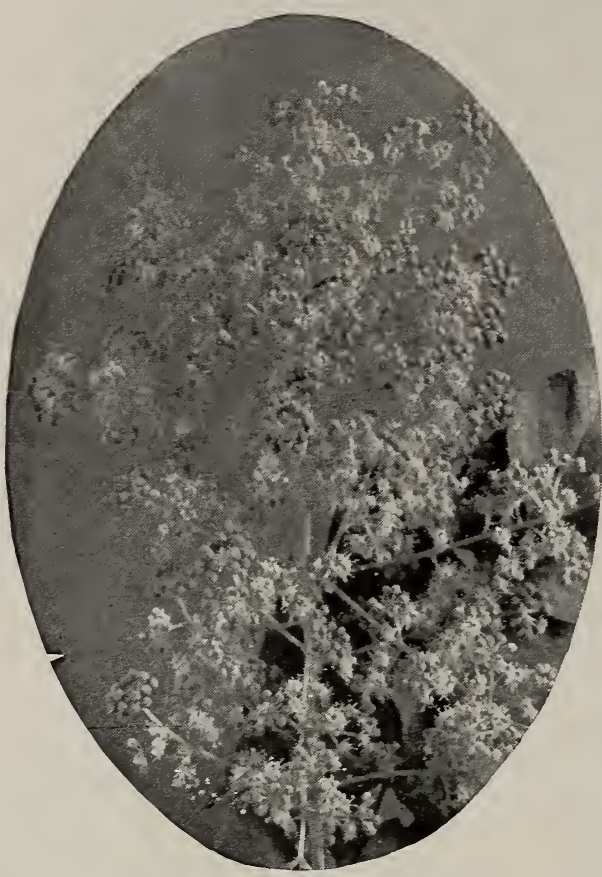

Flowers of Aralia spinosa

Speckled Alder in wet ground.

10 to $12 \mathrm{ft.}, 1$ to $11 / 2$ in.. $\$ 100 \quad \$ 850 \quad \$ 6500$

Alnus glutinosa

$\begin{array}{ccc}\text { Each } & 10 & 100\end{array}$

Alnus incana

A shrubby-growing small tree, thriving

Each 10

10 to $12 \mathrm{ft}$; 2 to $21 / 2$ in.......\$1 $50 \$ 1000$

\section{Chinese Angelica Tree}

Aralia japonica

A tropical-looking small tree, with huge divided leaves which are very ornamental.

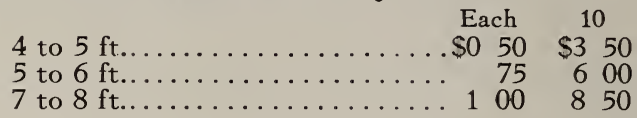

Monkey Tail, or Hercules' Club

Aralia spinosa

In appearance like the above, with stout, upright stems covered with thorns, whence the name. Much used where defensive planting is required, and of like value for its rich tropical foliage and great heads of creamy white flowers. $\quad$ Each $10 \quad 100$ 6 to $8 \mathrm{ft} . \ldots \ldots \ldots \ldots \$ 100 \quad \$ 8 \quad 50 \quad \$ 6000$

\section{Birches}

Betula

These trees are all very hardy, of graceful habit, with slender branches, and the bark usually possesses great attraction, especially in the white-barked varieties which mass especially well with evergreens. All are valuable in boundary and screen planting, thriving especially well in moist loam.

\section{Black or Sweet Birch}

Dark brown bark; tall-growing.

Betula lenta

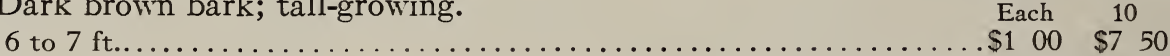

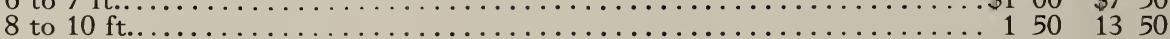

Yellow Birch

Betula lutea

Bark silvery gray; pretty when placed among evergreens.

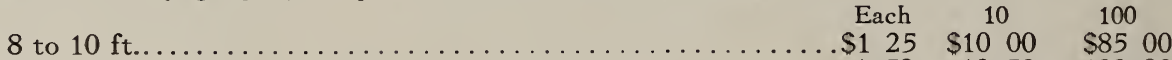

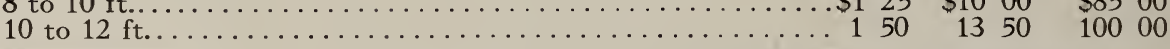




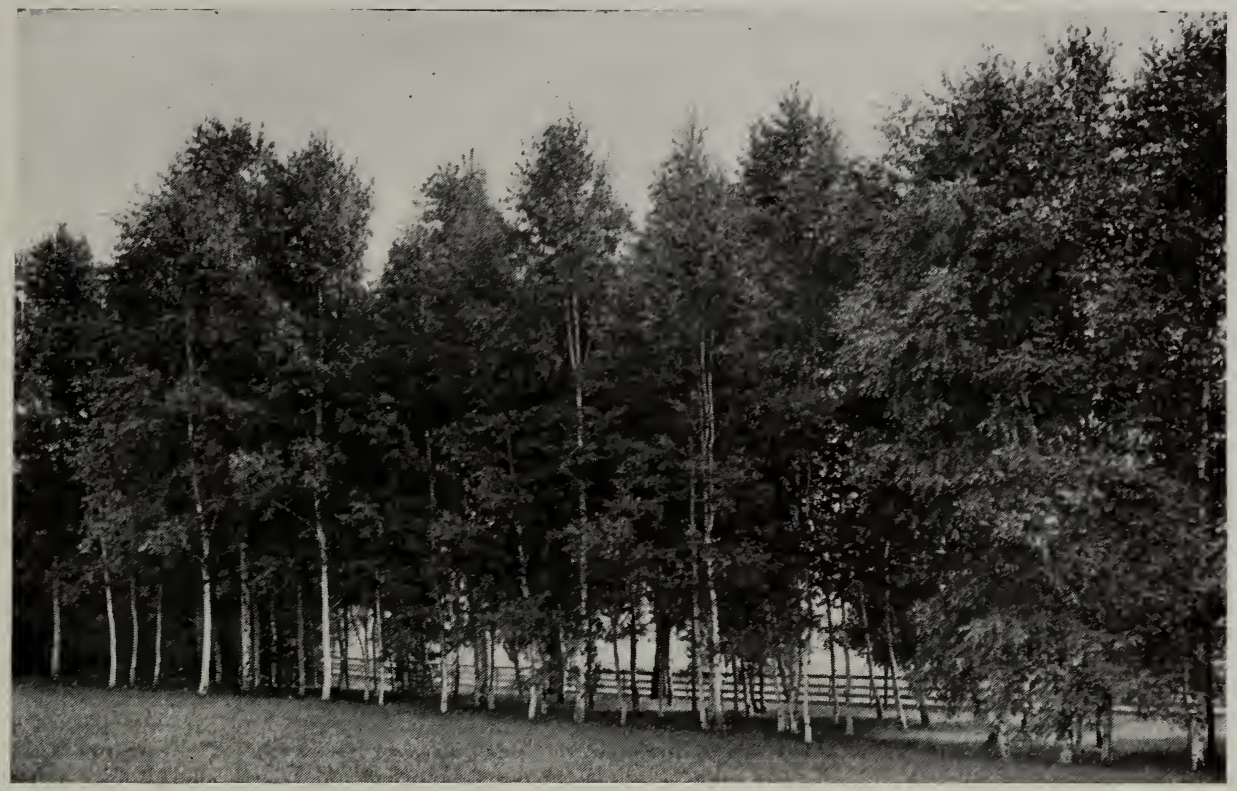

A border planting of Bircbes

\section{Paper or Canoe Birch}

Betula papyrifera

A well-known native tree, quick-growing and producing attractive winter effects.

Each $10 \quad 100$

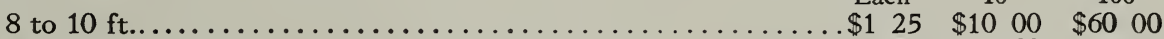

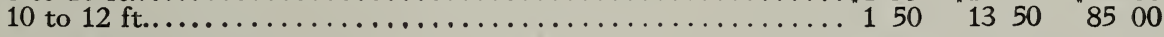

\section{American White Birch}

Thrives in the poorest soil, but is not long-lived.

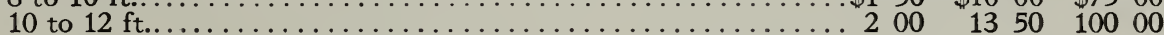

\section{River or Red Birch}

Especially fine for rather moist situations.

\section{Betula nigra (rubra)}

6 to $7 \mathrm{ft}$.

$\begin{array}{lll}\text { Each } & 10 & 100\end{array}$

7 to $8 \mathrm{ft}$

$\$ 100$

$\$ 750 \$ 6000$

14 to $16 \mathrm{ft}$. Specimens.

$\$ 3.50$ to 1000

$1000 \quad 7500$

\section{Nettle Tree}

Celtis occidentalis

A slow-growing, broad-spreading tree, of very distinctive type, with tiny coffee-colored fruits, little larger than a pea, covering the branches in the fall.

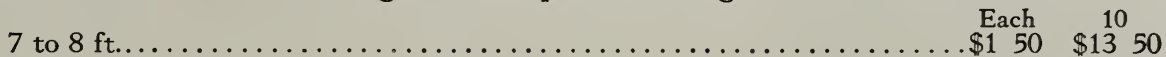

\section{American Beech}

Fagus ferruginea

This tree is endowed with the ability to withstand the shade of other fastergrowing trees, and so is useful for planting with such trees, where it will later take their place, as in an old wood or boundary planting. No tree surpasses it in habit, foliage, or attractiveness of its trunk, and when placed at the edge of plantings, it is of great ornamental value.

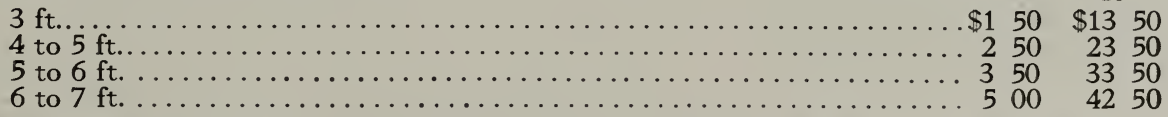


One of the most gorgeous trees in the fall in the tones of red and scarlet which the foliage assumes, and of very distinctive habit; especially suited to moist situations.

Each 10

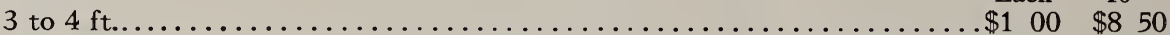

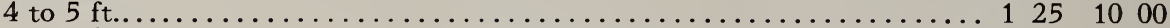

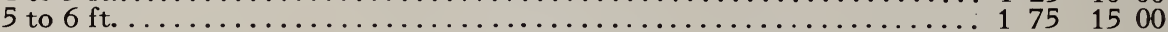

\section{Hop Hornbeam, or lronwood}

Ostrya virginica

An interesting small tree, suitable for planting at the edge of a wood or in tree borders.

Each

7 to $8 \mathrm{ft}$

$\$ 150$

Bolle's Silver Poplar

Populus alba, var. Bolleana

A tall, columnar tree, slightly resembling the Lombardy Poplar, but more wide-spreading, and with silvery leaves; quick-growing.

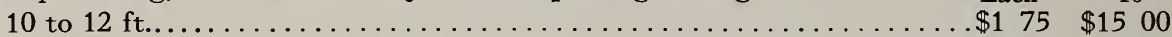

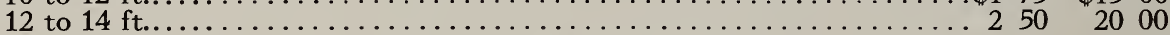

\section{Carolina Poplar}

Populus monilifera (carolinensis)

A symmetrical, rapid-growing tree, sometimes used as a street tree in crowded cities, but much better in high screen planting; not a long-lived tree.

8 to $10 \mathrm{ft}$

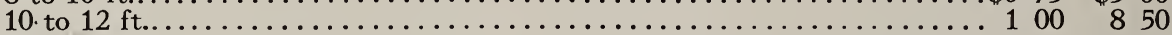

\section{Lombardy Poplar}

Populus nigra, var. fastigiata

This well-known tree has seemingly been done to death by planting it in rows in some places miles long; but, properly grouped, its tall, spire-like form is invaluable in Iandscape and architectural effects. Ulmus scabra is a longer-lived tree, producing about the same effect as the fast-growing Lombardy Poplar,

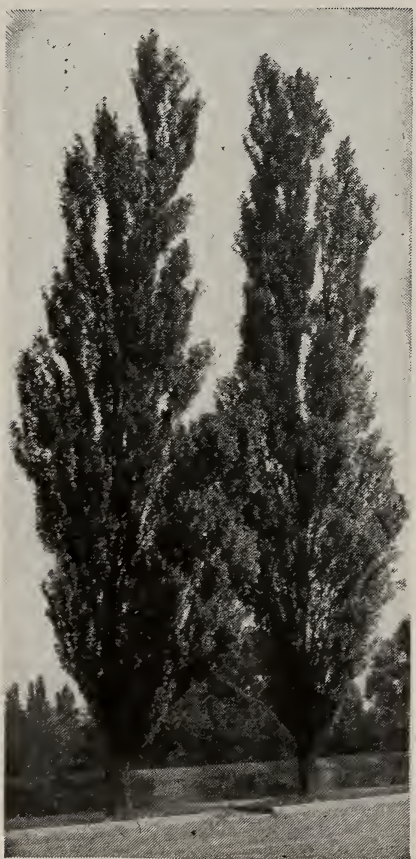

Tall Sentinel Poplars

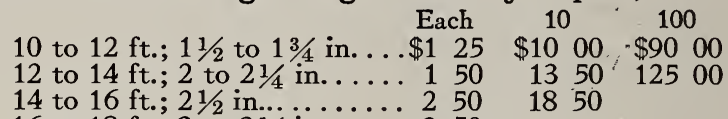

14 to $16 \mathrm{ft}$; $21 / 2$ in.......... 250

16 to $18 \mathrm{ft} ; 3$ to $31 / 4$ in...... 350

Sassafras

Sassafras officinale

The dark green leaves of summer turn to brilliant yellow-orange and red in faII, giving this tree great value for border or woods planting.

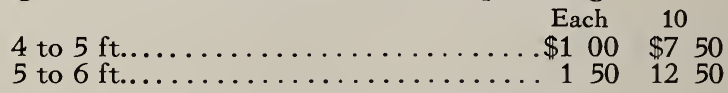

White Willow

Salix alba

A strong-growing tree for moist places.

Each 10

12 to $14 \mathrm{ft}$. Heavy.............\$3 $50 \$ \$ 3350$

\section{Rock Chestnut Oak}

\section{Quercus prinus}

Especially good for rocky places and poor ground. Foliage dark green, much like that of the American chestnut in color and shape. Each

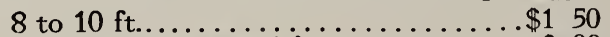

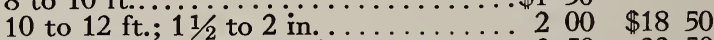

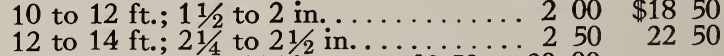

12 to $14 \mathrm{ft}$; 3 to $4 \frac{1}{2}$ in...... $\$ 3.50$ to 2000
10 


\section{GROUP II • MEDIUM HEIGHT}

European Cork Maple

Acer campestre

Usually branched to the ground, making a neai specimen or good screen.tree.

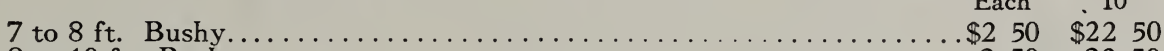

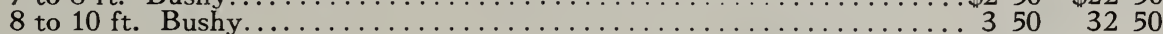

Tartarian Maple

Acer tataricum, var. ginnala

A shrub or small tree for screens or shrubberies. Most brilliant color effects in the faII and especially good on this account. Few trees have more desirable form for hillside planting, when low growth is desired. Its dwarf, dense form is clothed in foliage of great beauty in summer or autumn.

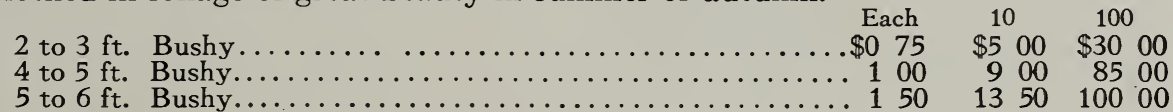

Siberian Pea Tree

Caragana arborescens

An upright-growing, smaIl tree, best in sandy soil and sunny positions. The pendulous variety is in the form of a standard.

American Hornbeam

Carpinus americana (caroliniana)

Shrubby tree, valuable for screens or may be trimmed into a good hedge.

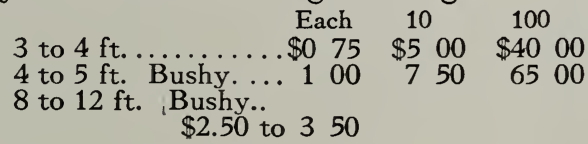

\section{European Hornbeam}

Carpinus betulus

Forms a dense, round head and holds its foliage Iater than the above; also fine for hedges.

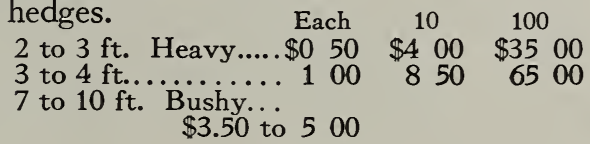

Kadsura Tree

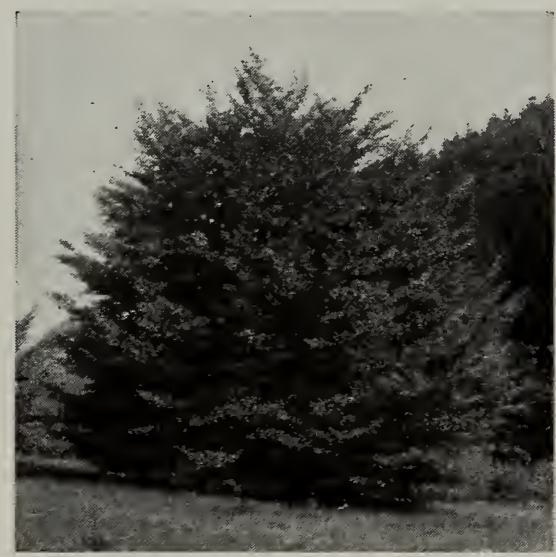

European Hornbeam grown as a specimen

Cercidiphyllum japonicum

Of pyramidal form, branched close to the ground, and especially desirable as a specimen or in borders on account of its beautiful coloring in yellow and salmonpinks in the fall. For specimen planting, this tree should be given ample room, for its spread of branches at the base will often equal two-thirds of its height and the lower branches are held close to the ground, though with an upward lift at the ends.

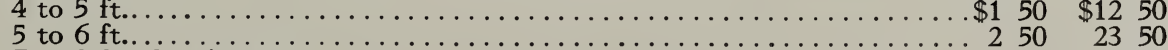

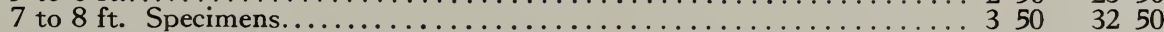

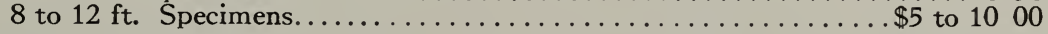

Hop Tree

Ptelea trifoliata

An interesting species on account of the clusters of small hop-like seeds in Iate summer. Use in the border or as a specimen.

Each 10

4 to $5 \mathrm{ft}$.

$\$ 035 \$ 300$

NO CHARGE FOR PACKING 


\section{Sumac}

Rhus

AII are rapid-growing, high shrubs; in summer beautiful for their fine foliage and in fall for the brilliant color of their leaves and clusters of red seeds which are held through the winter. They are aII vigorous growers even in very poor soils.

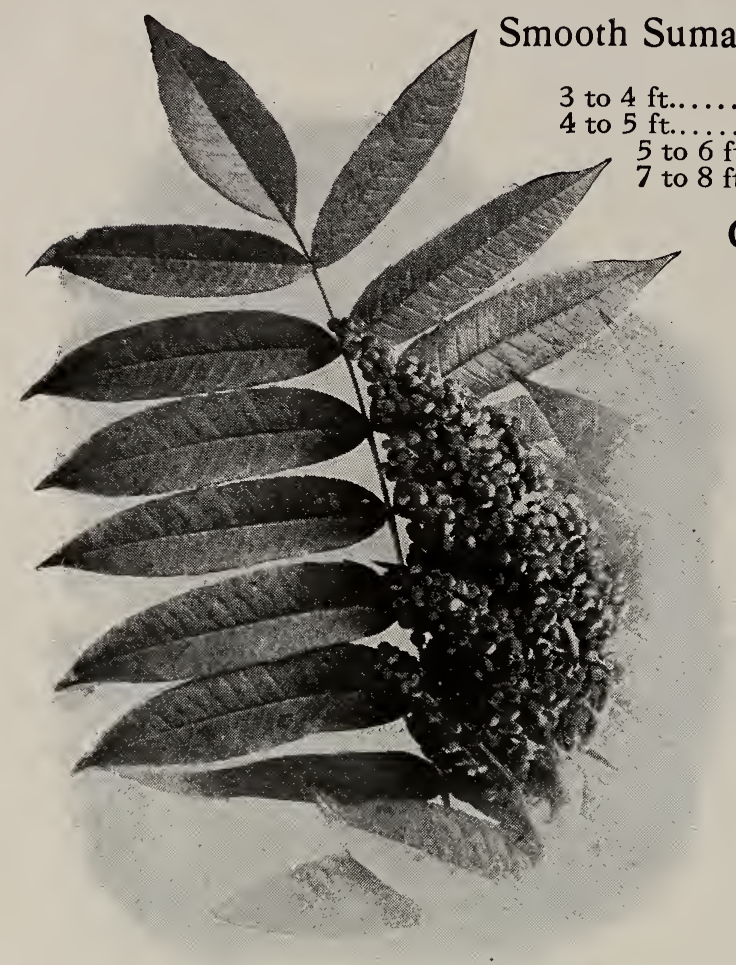

Smootb Sumac
Rhus glabra

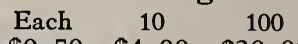

$\$ 400 \$ 3000$

$\begin{array}{llll}5 & 00 & 3500\end{array}$

$600 \quad 4000$

$700 \quad 5000$

\section{Cut-leaved Sumac}

Rhus glabra, var. laciniata

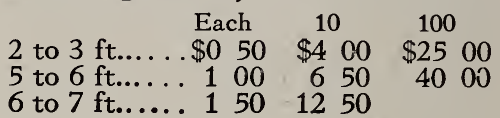

Staghorn Sumac

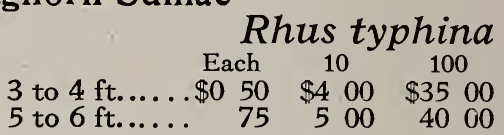

\section{Cut-leaved Staghorn Sumac}

Rhus typhina, var. laciniata

Foliage is very finely cut and lacy in effect; an excellent plant for massing with other shrubs and for planting on banks and waste land.

$$
\begin{array}{rrrr}
4 & \text { Each } & 10 & 100 \\
5 \text { to } 5 \mathrm{ft} . \ldots . . \$ 075 & \$ 600 & \$ 3500 \\
5 \text { to } 6 \mathrm{ft} . \ldots . .1 & 25 & 750 & 5000
\end{array}
$$

\section{Osbeck's Chinese Sumac}

Rhus osbeckii Each 10

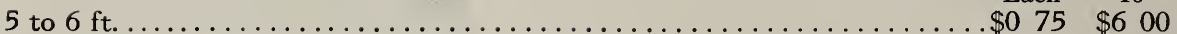

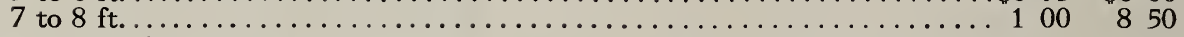

Cut-leaved Chinese Sumac

Rhus osbeckii, var. laciniata Each 10

5 to $6 \mathrm{ft}$.

.\$1 $00 \quad \$ 750$

Pussy Willow

Salix caprea

We have all known this early harbinger of spring since childhood and it will grow in almost any soil. Plant in the shrubbery where the children will search for the "pussies" in the spring.

7 to $8 \mathrm{ft}$.

Each

10

Laurel-leaved Willow

Salix pentandra

One of the most valuable dense-growing low trees for quick effects in screen planting; foliage clean shiny green; good at the seashore and where a dense screen is required from the ground up. The California Privet may be planted at its base as its foliage is not unlike that of this tree, and for tall formal screens they may be trimmed as one.

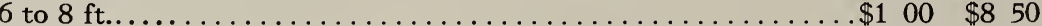

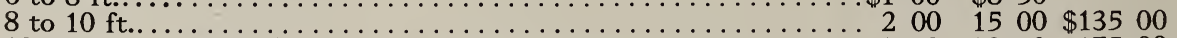

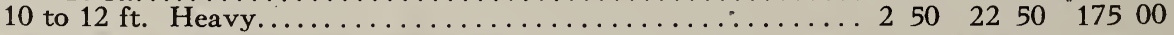




\section{Colored-Foliage Effects with Deciduous Trees}

7 HERE are many forms of both trees and shrubs with colored foliage, the effect of which is not always the happiest or in the best taste. The following varieties represent the most dignified and lasting sorts, those whose rich colors are not offensive, but really lend a pleasing contrast as specimen trees or in groups.

The Japanese Maples, which are sometimes classed as trees, are to be found under the heading, "Especially Noteworthy Species of Shrubs for Spring Effects;" their handsome crimson coloring being especially pleasing in the early spring, particularly against a background of evergreens.

\section{Schwedler's Purple Maple} Acer platanoides, var. Schwedleri

The foliage in the spring is in rich shades of purplish crimson, fading to green in summer and again in the fall taking on shades of red and purple. In habit like a Norway Maple; quickgrowing, with dense, rounded top and sturdy trunk. One of the few colored trees that harmonize with most others of green foliage.

\begin{tabular}{|c|c|c|}
\hline Each & 10 & 100 \\
\hline $\begin{array}{l}8 \text { to } 10 \mathrm{ft} . ; 1 \frac{1}{2} \mathrm{in} . . \$ 175 \\
10 \text { to } 12 \mathrm{ft} ; 1^{3} / 4\end{array}$ & $\begin{array}{r}\$ 1500 \\
18 \quad 50\end{array}$ & $\$ 13500$ \\
\hline 10 to $12 \mathrm{ft} ; 2 \frac{1}{2}$ & & \\
\hline $\begin{array}{l}\text { to } 23 / 4 \mathrm{in} . . . \ldots 350 \\
12 \text { to } 14 \mathrm{ft} . ; 23 / 4\end{array}$ & 3250 & \\
\hline to 3 in........ 500 & & \\
\hline $\begin{array}{l}14 \text { to } 16 \mathrm{ft} . ; 31 / 2 \\
\text { to } 4 \text { in. } \$ 7.50 \text { to } 1000\end{array}$ & & \\
\hline $\begin{array}{l}16 \text { to } 20 \mathrm{ft} ; 5 \text { to } \\
10 \mathrm{in.} . \$ 25 \text { to } 15000\end{array}$ & & \\
\hline
\end{tabular}

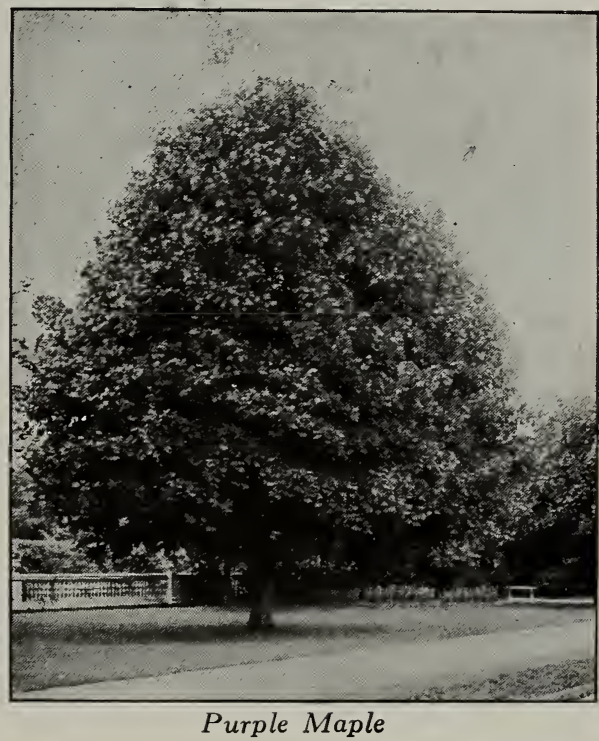

Reitenbach's Purple Maple

Acer platanoides, var. Reitenbachii

Similar in form to the above; its spring foliage is deeper color and in summer the purple shade is more pronounced, lasting well into the late faII. Each 10

6 to 7 ft............................................ $100 \quad \$ 850$

\section{Purple Sycamore Maple}

Acer pseudoplatanus, var. purpureum

Leaves purplish red beneath, dark green above, rich in appearance throughout the season; a spreading tree, not flowering so freely as the green form, but rich in effect with its yellow bloom against the rich foliage.

Each

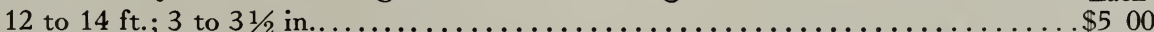

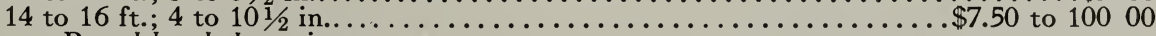
Broad-headed specimen trees.

\section{Purple-leaved White Birch}

Betula alba, var. purpurea

The purple leaves show off to advantage against the white bark. TaII and graceful as a specimen and can be used to advantage grouped with other Birches or against the deep green foliage of the trees.

Each 


\section{Copper or Purple Beech}

Fagus sylvatica, var. purpurea

A most beautiful lawn specimen, with its lower branches sweeping the ground and. rișing above in a dome-like head. Foliage of a decided coppery cast in spring, changing to rich green tinged with purple in summer.

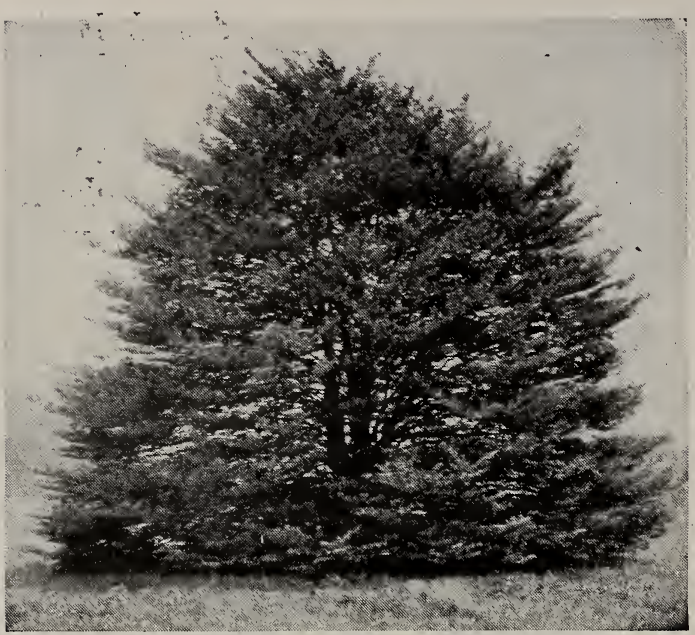

Copper Beecb

4 to $5 \mathrm{ft} . \ldots \ldots \ldots \$ 150 \quad \$ 1250$

5 to $6 \mathrm{ft} . \ldots \ldots \ldots 250$ 23 50

6 to $7 \mathrm{ft.. \ldots \ldots \ldots ..350} 3250$

7 to $8 \mathrm{ft} \ldots \ldots \ldots .500 \quad 4750$

9 to $10 \mathrm{ft}$. Specimens $\$ 7.50$ to 1000

11 to $12 \mathrm{ft}$. Specimens $\$ 10$ to 2500

12 to $25 \mathrm{ft}$. Specimens $\$ 25$ to 25000

\section{Large-leaved Copper Beech Fagus sylvatica, var. purpurea major}

This variety is very similar to the above, except as to size of leaves, which are larger. Being grafted stock, it is more uniform in depth of color.

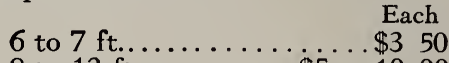

8 to $12 \mathrm{ft} . \ldots \ldots \ldots \ldots \ldots+\ldots 5$ to 1000

Fagus sylvatica, var. Riversii

Rivers' Blood-leaved Beech

This form of the purple Beech is from grafted stock and, while it holds the fuIl beauty and form of the English Beech, its foliage is much darker and richer than the Copper or Purple Beech. The fact of its being a grafted tree insures absolute uniformity in color. The gray bark and twigs of this, as of all the other Beeches, are very pleasing in winter. Rivers' Beech needs to be used very carefully where a strong high-colored specimen is desired. As an excellent tree in a planting or as a single specimen upon the lawn it is equally valuable.

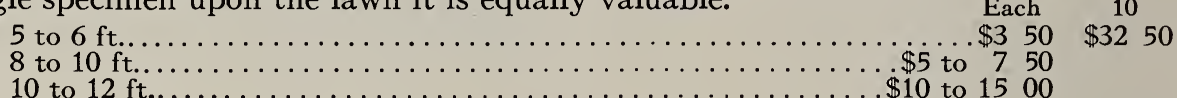

Purple-leaved Plum

Prunus pissardii

A handsome, symmetrical small tree of formal appearance, holding the purple color of its foliage through the hottest weather.

Each 10

5 to $6 \mathrm{ft}$. Specimens.

$\$ 150 \quad \$ 1250$

Golden Oak

Quercus pedunculata, var. concordia

A form of the English Oak with beautiful, warm yellow-green leaves and symmetrical habit of growth.

Each $\quad 10$

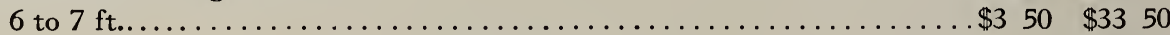

\section{Purple-leaved Wych Elm}

Ulmus scabra, var. purpurea

A medium-sized tree with a pleasing purplish cast to the foliage; a splendid specimen and of merit when a medium-sized tree is required. The growth is close; the foliage small and of good color. Often a tree is required for planting along paths or narrow roads. This is a desirable variety for such a purpose or, in general landscape planting where a tree of very symmetrical outline and of medium growth is required, it can be used with the greatest advantage.

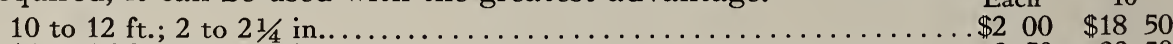

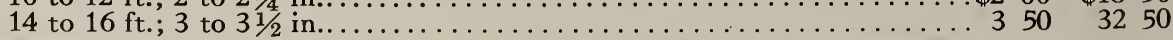




\section{Trees . Deciduous Conifers}

$\mathrm{T}$ HESE trees are decidedly interesting from the fact that they shed their leaves in winter, although they are conifers like the Pine and Spruce. Aside from this, they are distinctive in form and for their rich golden yellow autumn coloring.

\section{European Larch}

Larix decidua (europæa)

A quick-growing, conical-shaped tree with graceful, horizontal, twiggy branches. In early spring the leaf-buds appear like tiny pink and green blossoms, followed by the soft light green foliage. Plant in well-drained soil.

$\begin{array}{lll}\text { Each } & 10 \quad 100\end{array}$

5 to $6 \mathrm{ft}$

$\$ 100$

$\$ 750 \$ 5000$

\section{Japanese Larch}

Larix leptolepis (kaempferi)

A native of Japan; tall and stately, and very formal in appearance. Foliage soft bluish green, fading in fall to warm shades of yellow. Thrives best in light moist soils where its growth is very rapid. It is particularly pleasing in its rich feathery foliage, and in all one of the most desirable of specimen trees.

Each 10

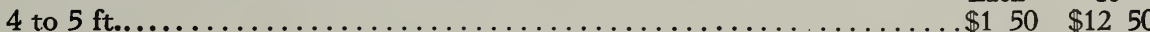

\section{Bald Cypress}

Of very narrow, pyramidal or columnar form, with soft green, light, airy foliage. The bark is a cinnamon-brown, against which the foliage shows fine contrasting color. Naturally best suited to very moist situations, but grows well on the upland. Where very rapid growth is desired it is very effective.

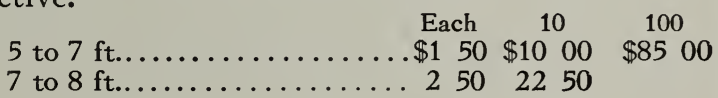

\section{Ginkgo, or Maidenhair Tree}

\section{Ginkgo biloba (Salisburia adiantifolia)}

Very hardy and a vigorous grower; a tree which, in its younger stages, maintains an upright columnar growth, later forming a spreading head. A very satisfactory avenue tree when carefully pruned to secure proper form in its early growth. When left untrained, it is apt to start irregular branches, forming an open, irregular head of great charm. Curious leaves, like a Maidenhair Fern, are pale green until they turn to rich golden yellow in the fall. The Ginkgo transplants very easily and adapts itself to heavy or light soils. It is also a splendid grower in places where soot and smoke make planting a hard problem.

\begin{tabular}{|c|c|c|}
\hline Each & 10 & 100 \\
\hline 7 to $8 \mathrm{ft} . ; 1$ to $1 \frac{1}{4} \mathrm{in}$. & $\$ 1350$ & $\$ 10000$ \\
\hline 8 to $9 \mathrm{ft}$.; $11 / 4$ to $11 / 2 \mathrm{in}$.. & 1750 & 12500 \\
\hline 10 to $12 \mathrm{ft}$; $1 \frac{1 / 2}{2}$ to $13 / 4$ in. & 2000 & 17500 \\
\hline 12 to $14 \mathrm{ft} . ; 21 / 4$ to $21 / 2 \mathrm{in.} .350$ & 3250 & \\
\hline
\end{tabular}

12 to $14 \mathrm{ft}$; $2 \frac{1}{2}$ to 3 in.... 500

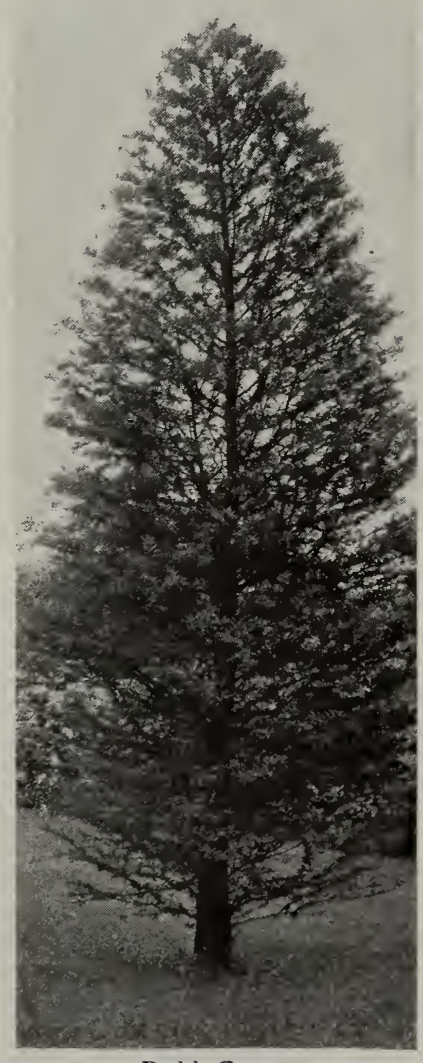

Bald Cypress 


\section{Our Friends the Birds}

W

ITH what keen delight do we look forward to the first song-birds, those harbingers of spring which seem to bear to us the promise of opening bud and busy activities of reawakening life; but how little do we sometimes appreciate what added enjoyment might be ours at all seasons of the year if in our plantings we provided a little more thoughtfully for the reception of our cheery neighbors! The Bluebirds and Cedar Waxwings will appreciate a group of Cedars or Junipers for their little households, and the Catbirds, Finches, and Song Sparrows will frII our shrubberies with their calls and songs if we but plant trees and shrubs where they may conveniently feed. AII these feathered neighbors repay us in more than a pleasurable way for they will help us keep in check all the insect enemies of our trees and gardens.

Let us remember that the birds like to hide their nests away in masses of trees, shrubs, and thickets, where they can find cool and shadow in the hot summer, and that the thick-growing evergreens give them protection in winter. The list of plants which follows will attract birds of many sorts and will keep them with us long into the fall and early winter and provide the needed protection, seeds, and berries for those that stay with us through the long winter months.

\section{DECIDUOUS SHRUBS}

Spice Bush

Japanese Barberry

Common Barberry

AlIspice, or Sweet Shrub

Sweet Pepperbush

Siberian Red Osier

Cornelian Cherry

Panicled Dogwood

European Red Osier

Silky Dogwood

American Red Osier

Strawberry Bush

Spindle Tree

Japanese Winterberry

American Winterberry

European Privet, or Prim

Tartarian Bush Honeysuckle

Red Chokeberry

Buckthorn

Black EIderberry

Coral Berry, or Indian Currant

Snowberry

Blueberry, or Swamp Huckleberry

Withe-rod or Wild Raisin

Arrow-wood

Sheepberry

High-bush Cranberry

Black Haw

Siebold's Viburnum

\section{EVERGREEN TREES}

American HoIly

Japanese Holly

Canadian Juniper

Red Cedar

Ground Savin

\section{EVERGREEN SHRUBS}

Japanese Yews and varieties

English Yews and varieties

Canadian Yew

Evergreen Thorn

Himalayan Quince Berry

\section{DECIDUOUS TREES}

European or Black Alder

Shad-bush, or Service Berry

European Bird Cherry

Wild Black Cherry

White-flowering Dogwood

Carriere's Thorn

Scarlet Thorn

Washington Thorn

Cockspur Thorn

Sweet Magnolia

White Mulberry

Staghorn Sumac

Smooth Sumac

American Mountain-Ash

European Mountain-Ash 


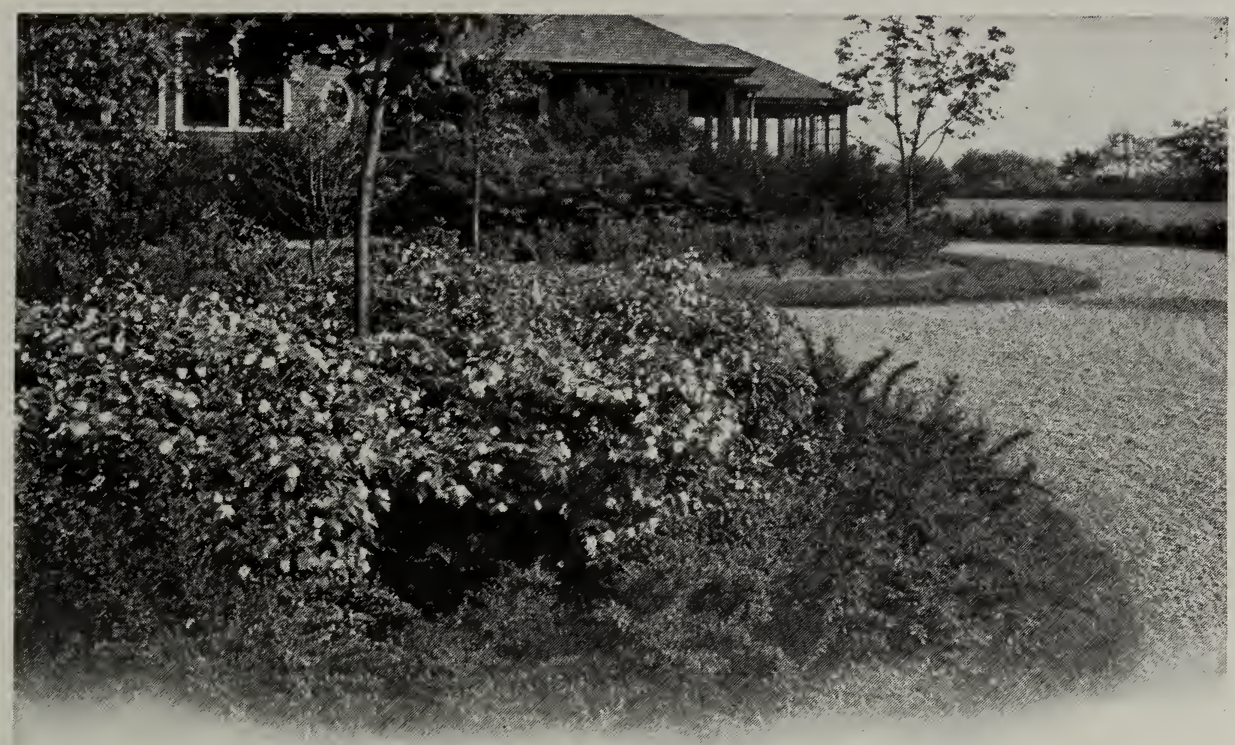

\section{Deciduous Shrubs}

T $N$ the arrangement of our catalog of shrubs we have had in mind two things: first, that most of us, in planning our places in which we live the year around, should so arrange our plantings that a continual effect of beauty and interest is attained; and again, that many are so fortunate as to be able to spend the winter in one place and the warmer months of the year in another, perhaps on a rejuvenated old farm in the hills or on a more pretentious estate, where the pleasing appearance of the place from early spring till late fall is of greatest importance. A natural disposition of the planting design of any place is a close association with the house of the finer, more finished Deciduous Shrubs and Evergreens, and a dependence upon masses of color of flower, foliage, and twig in the borders of shrubs, where the full effect is better obtained in views from the house.

Even on the smallest town or suburban place we can always obtain effects, pleasing in their changing attractions from one season to another, by the planting of borders of the different varieties of shrubs, chosen with respect particularly to their

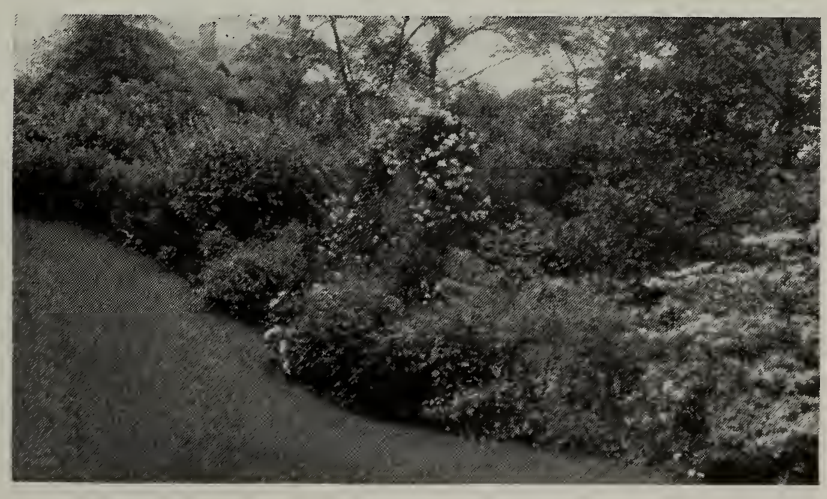

NO CHARGE FOR PACKING 
effectiveness at one season or another. Such borders at the sides and front of any place will also lend an appearance of greater breadth to the lawn and will assure a greater privacy than the common practice of hedgeplanting. It is well always to keep in mind that the charm of the very early spring bloomers and those shrubs with bright fall and winter twigs and berries is enhanced by the contrasts secured by the judicious planting of evergreens in masses in the borders or as specimens at the edges of the lawn.

It is rather hard to draw arbitrary lines in any classification of plants that will define their principal attractions, as the uses of all plants on closer acquaintance are so many and varied; but we have cataloged our shrubs according to their greatest effectiveness, broadly speaking, in spring, summer, fall, and winter. This we believe will be most practicable for the greatest number of our customers.

Particular attention is called to that class of shrubs suitable for groundcovers, and we strongly urge careful consideration of these plants in the planting of shrubbery borders. Nothing is more unsightly than a shrubbery border where little attention has been paid to the ground-cover, and by reason of this oversight the planting is made with those shrubs which have a more upright growth, thus showing the bare stems of the plants and the uncovered ground beneath.

\section{DECIDUOUS SHRUBS}

Shrubs for Spring Effects, page 101.

Especially Choice Varieties, page 101.

Spring Flowers in the Shrubbery, page 109.

Midsummer Effects, page 129.

FaII and Winter Effects with Shrubs, page 135.

Ground-Covers and Special-Purpose Shrubs, page 139.

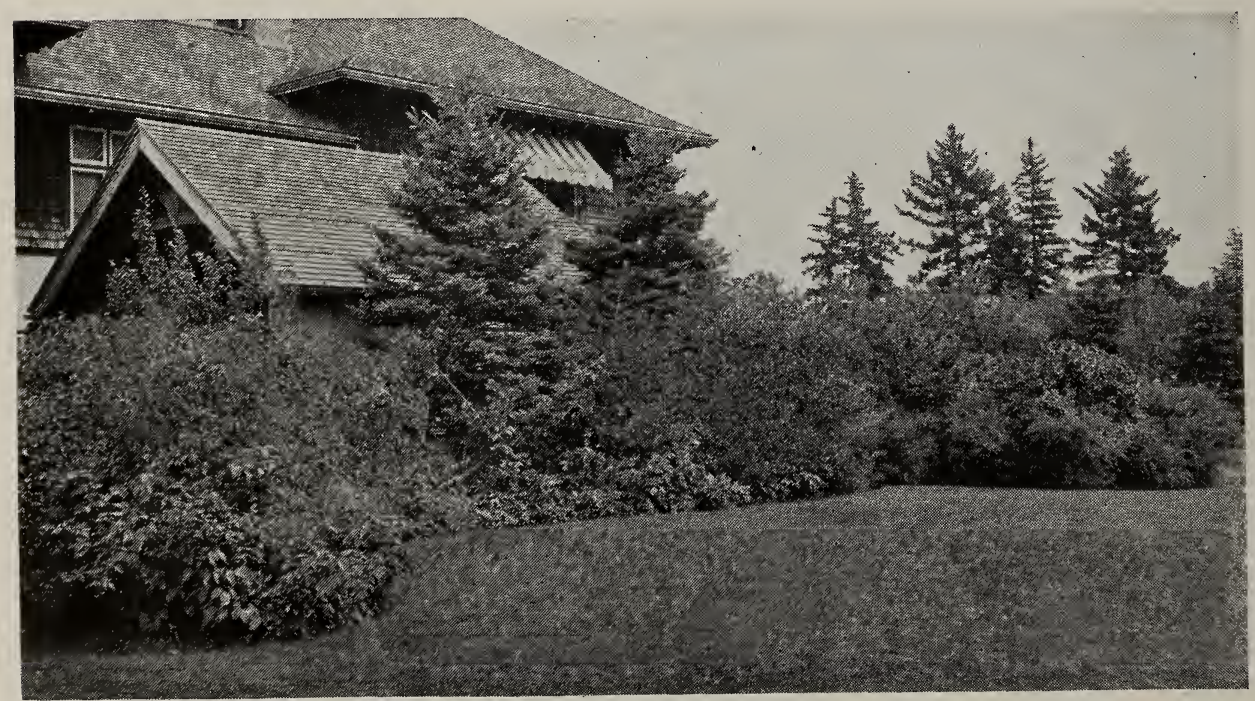

An effective boundary planting of tall sbrubs, showing a judicious use of evergreens 


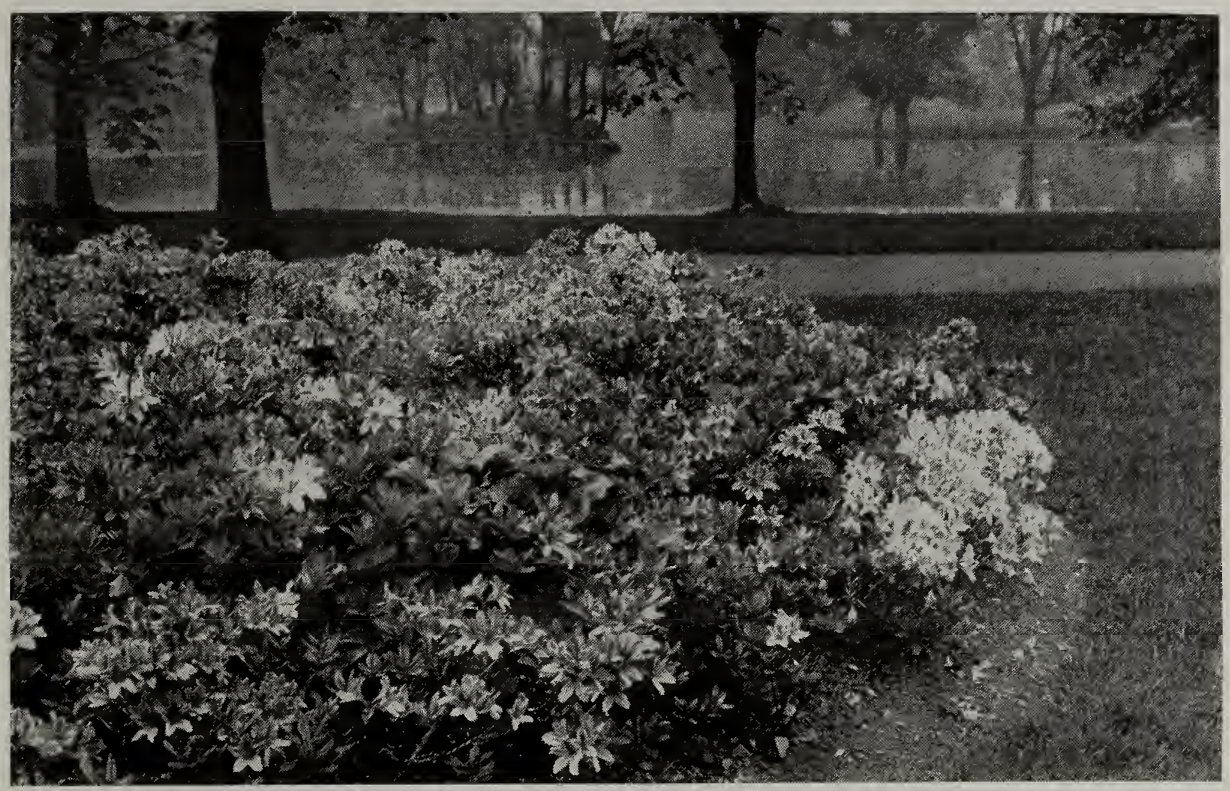

\section{Shrubs for Spring Effects Especially Choice Varieties}

$\mathrm{W}^{\mathrm{t}}$

E DEEM it of interest to our patrons to draw their especial attention to a group of plants which, outside of the Hybrid Rhododendrons and Evergreen Azaleas, furnish us with material for the most gorgeous and decorative effects of profuse bloom in early spring. These plants are all rather slow-growing and for that reason should be allowed ample room for development in masses or groups by themselves, and their effectiveness is greatly enhanced when evergreens are so arranged as to act as a foil to their wonderful flowers that appear before the leaves.

All of this group of plants, on account of their neat habits of growth, are especially adaptable to garden use and for close association with the house.

\section{Deciduous Azaleas}

These are among the most radiant of all flowering plants. The frrst six varieties are covered completely in early spring with beautiful flowers of the gayest and most brilliant colors, and the last four continue the blooming season with their profuse, delicate blossoms of pink and white well into late June.

Ghent Azaleas

Azalea pontica

We have selected, in our Nurseries, the hardiest varieties, ranging in color from white through yellow to the most vivid shades of orange and vermilion.

Each 10

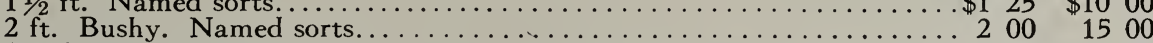

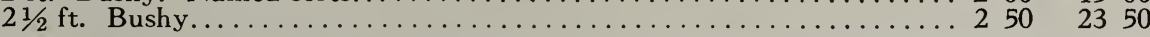




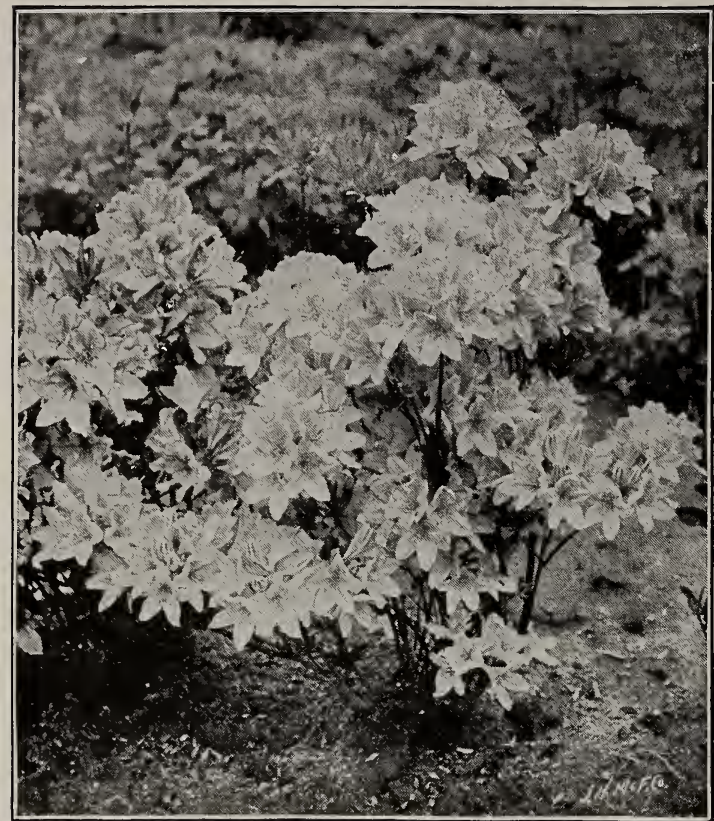

Azalea mollis

Japanese Azalea Azalea mollis

The flowers rival in size the tender hothouse Azalea in white and shades of yellow, red, and orange.

$11 / 2 \mathrm{ft}$. Named

sorts.........\$1 $25 \quad \$ 1000$

$2 \mathrm{ft}$. Bushy.

Named sorts. . $150 \quad 1350$

$21 / 2 \mathrm{ft}$. Bushy.

Named sorts.... $250 \quad 2250$

\section{Azalea Fuji-manyo}

A spreading shrub with light purple flowers of distinct character.

2 to $2 \frac{1}{2} \mathrm{ft}$.

Each $10 \quad 100$

$\$ 200 \$ 1850 \$ 16500$

\section{Yodogawa Azalea}

\section{Azalea ledifolia, var. narcissiflora}

Low-growing and sprcading in habit. The rosy purple flowers make this beautiful Japanese plant of great interest and merit.

\begin{tabular}{|c|c|c|c|}
\hline 18 in... & 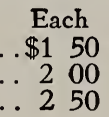 & $\begin{array}{r}10 \\
\$ 1350 \\
1650 \\
2000\end{array}$ & $\begin{array}{r}\$ 15000 \\
18500\end{array}$ \\
\hline
\end{tabular}

Flame Azalea

Azalea calendulacea

The large brilliant blossoms, shading from lemon-yellow to the richest orangered, make these plants a blaze of color in late May. This variety is exceptionally well suited for mass planting on banks and along the boundaries of evergreen plantings, where in favorable soils they will attain a height of 6 to 8 feet, carrying an abundance of twigs all the way to the ground and clothing themselves with perfect masses of flowers.

Each

$10 \quad 100$

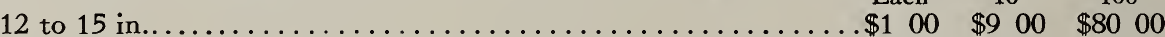

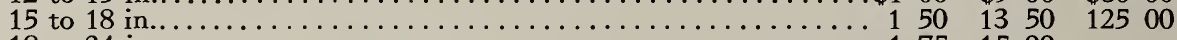

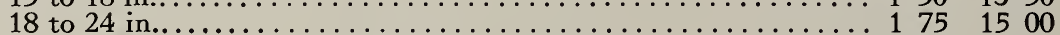

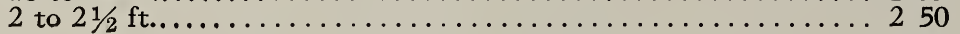

Rhodora

Azalea canadensis

Low-growing and covered with soft rosy purple flowers in May; excellent for bog-gardens or moist places but does well in other situations.

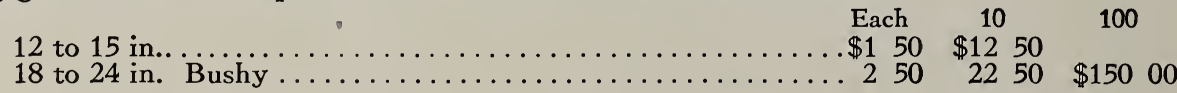

Southern Azalea

Azalea vaseyi

A graceful bush with exquisite shell-pink flowers in April or May.

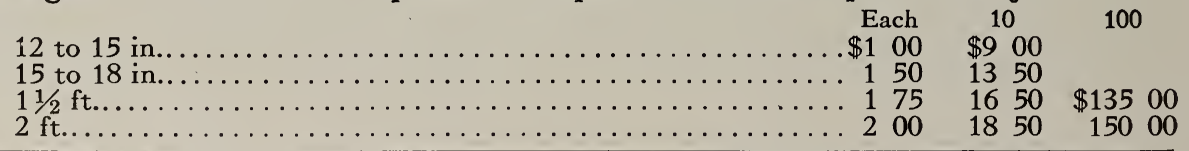




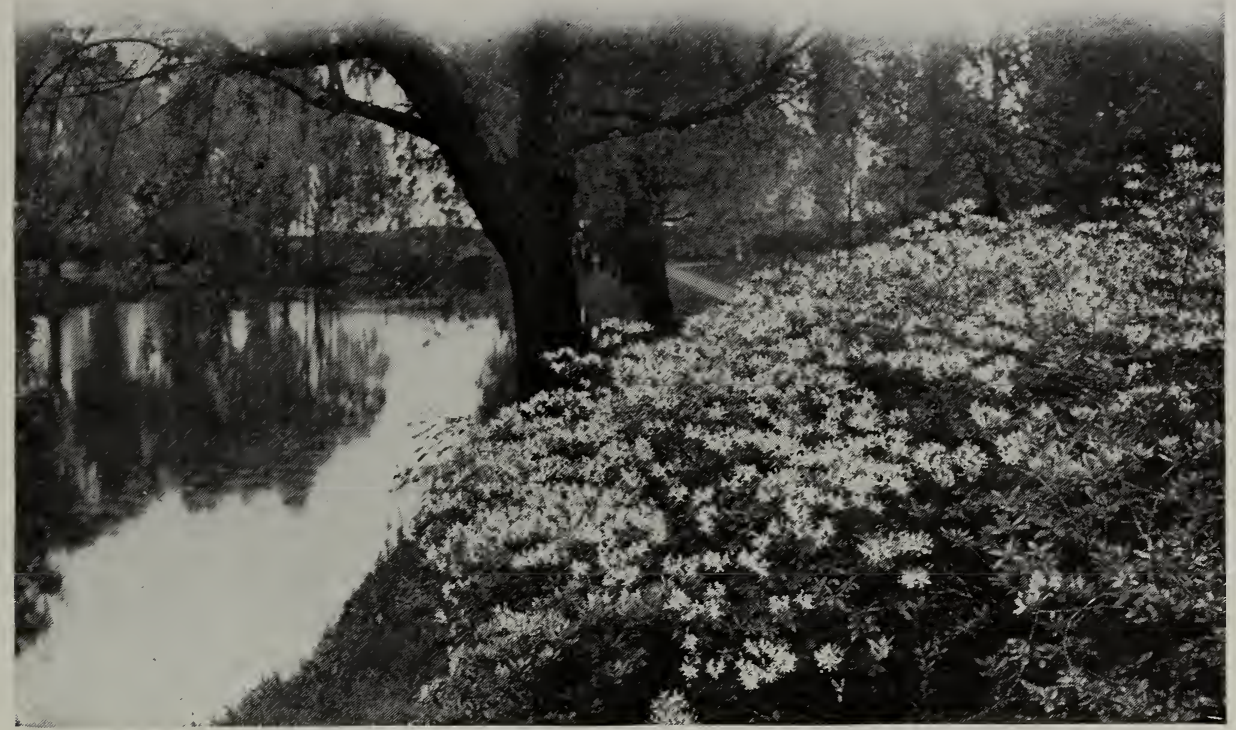

Mass of Pinxter Flowers growing at the water's edge

\section{Pinxter Flower}

Azalea nudiflora

Has a most fascinating loose and open habit of growth and in May is covered with enchanting deep pink blossoms. This is the Azalea, so commonly known as the Wild Woods Honeysuckle, valuable for gardens and moist places, and of the greatest value when planted with Calendulacea and Arborescens along the border of the woodland or of heavy screen plantations.

$\begin{array}{rrr}\text { Each } & 10 \\ 15 \text { to } 18 \text { in. Clumps.......... } \$ 150 & \$ 13 & 50 \\ 11 / 2 \mathrm{ft} \text {. Bushy clumps........ } 175 & 1500\end{array}$

\section{Fragrant Azalea Azalea arborescens}

Of the easiest cultivation, of broad bushy habit, covering itself in June with a profusion of highly perfumed white flowers. This variety is particularly useful in that it holds such splendid foliage throughout the summer and long into the early winter. During the Iate fall the leaves turn to rich shades of brown and bronze, giving a most pleasing and attractive fall color.

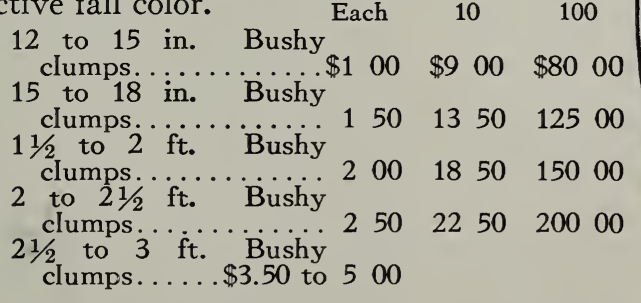

White Summer Azalea Azalea viscosa

Fragrant white flowers in July. Ideal for damp situations or on the banks of streams or ponds.

Each 10

15 to 18 in.............\$1 $50 \$ 1350$

18 to 24 in..................... 175 1650

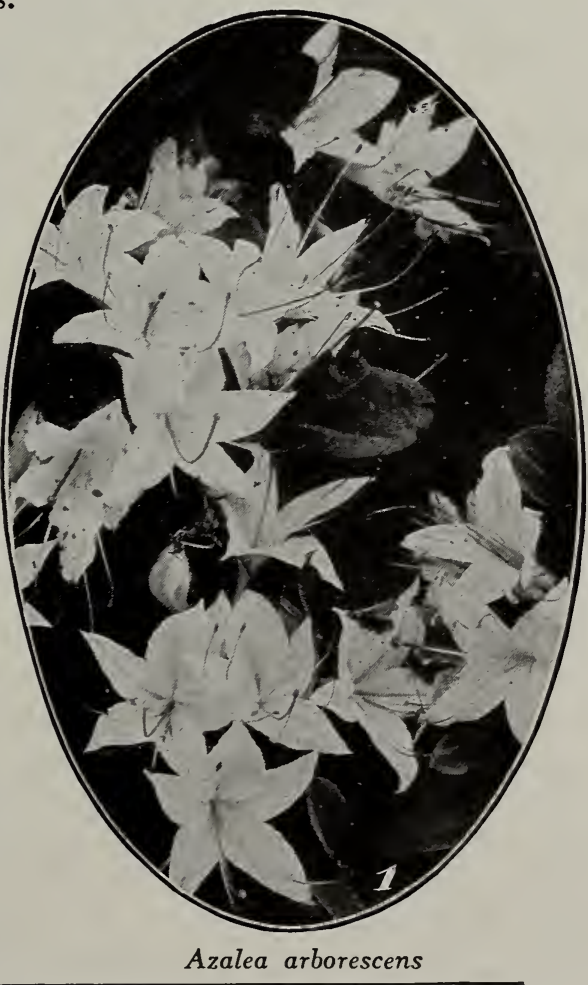

NO CHARGE FOR PACKING 


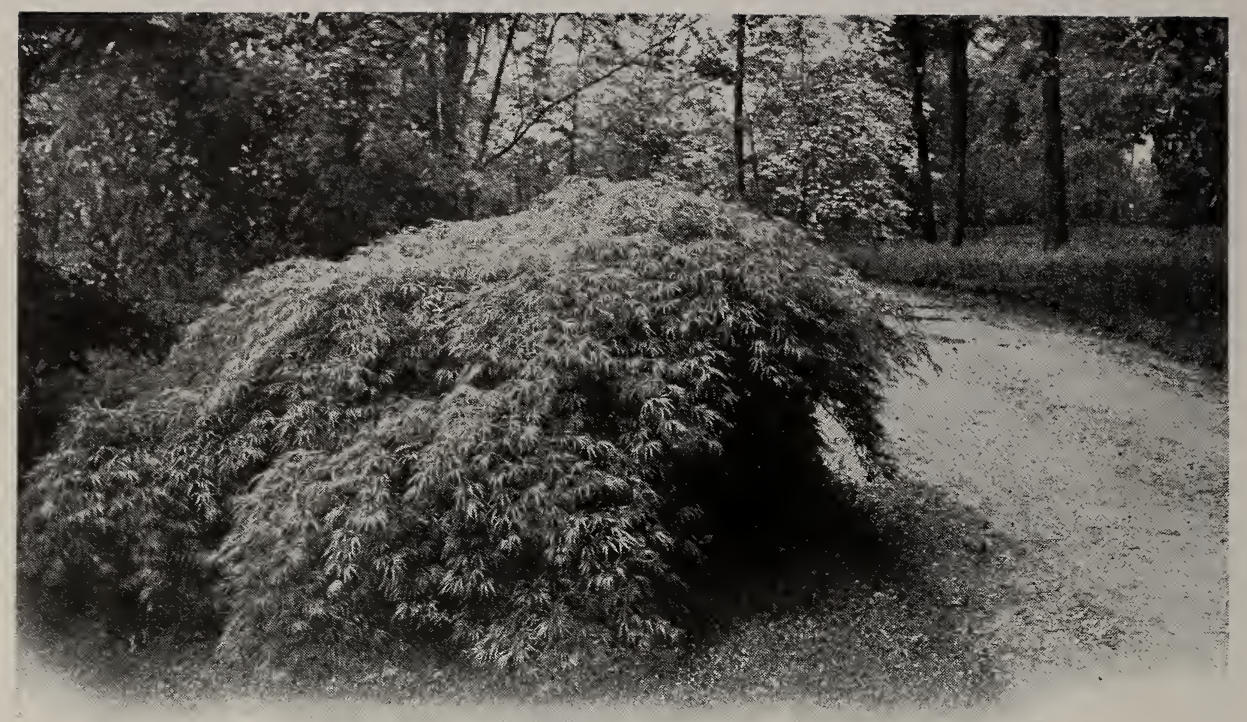

\section{Japanese Maples}

The coloring of the spring foliage of these characteristically Japanese plants has an individuality aII its own in its fresh richness. As specimens, in groups, or when planted as a component part of evergreen borders, their pretty colors are equally effective. These plants are all dwarf-growing, and those which we offer are in many cases much broader than they are high; they differ principally in the form and color of the leaves, and in their attractive coloring in early spring and late faII.

\section{DWARF VARIETIES}

ACER palmatum, var. aureum. GoIden Japanese Maple. Each

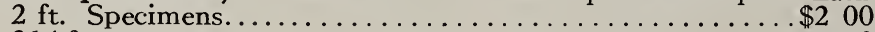

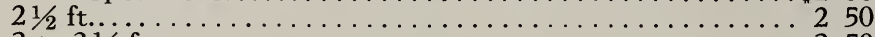

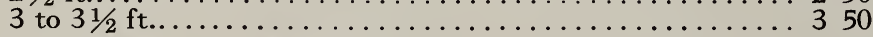

*A. palmatum, var. filicifolium.

7 to $9 \mathrm{ft}$...

3250

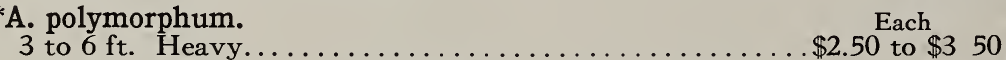
.. $\$ 1000$

*A. polymorphum, var. atropurpureum. Blood-leaved Japanese Maple.

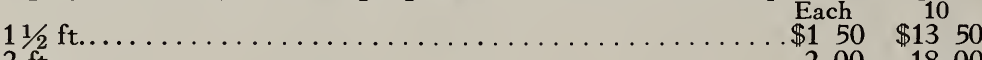

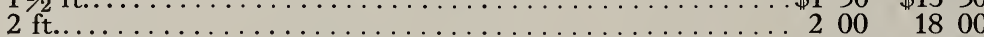

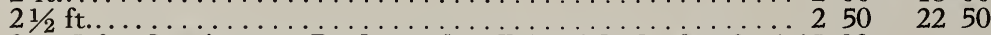

3 to $5 \mathrm{ft}$. Specimens. Bushy and well furnished. $\$ 3.50$ to 1500

A. polymorphum, var. atropurpureum dissectum. Weeping Cut-leaved Blood-leaved Japanese Maples. $11 / 2 \mathrm{ft}$

Each 10 \%

2 to $21 / 2 \mathrm{ft}$. Specimens............................ $\$ 3.50$ to 1000

Tall standards, 4 to $5 \mathrm{ft}$., stem and broad heads...\$15 to 2500

*A. polymorphum, var. atropurpureum nigrum.

Each

7 to $10 \mathrm{ft}$. Specimens....................... \$25 to $\$ 7500$

A. polymorphum, var. dissectum. Cut-leaved Weeping Japanese Maple.

$11 / 2 \mathrm{ft}$

Each
$\$ 250$
750

$21 / 2$ to $3 \mathrm{ft}$. by $2 \frac{1}{2}$ to $4 \mathrm{ft} . \ldots \ldots \ldots \ldots \ldots \ldots \ldots \ldots \ldots \$ \ldots 7.50$ to 1500

*Taller varieties growing to a height of 12 or 15 feet as low-headed trees.
$\$ 2250$

Varied leaf-
forms of the

Jap a n ese Maples 


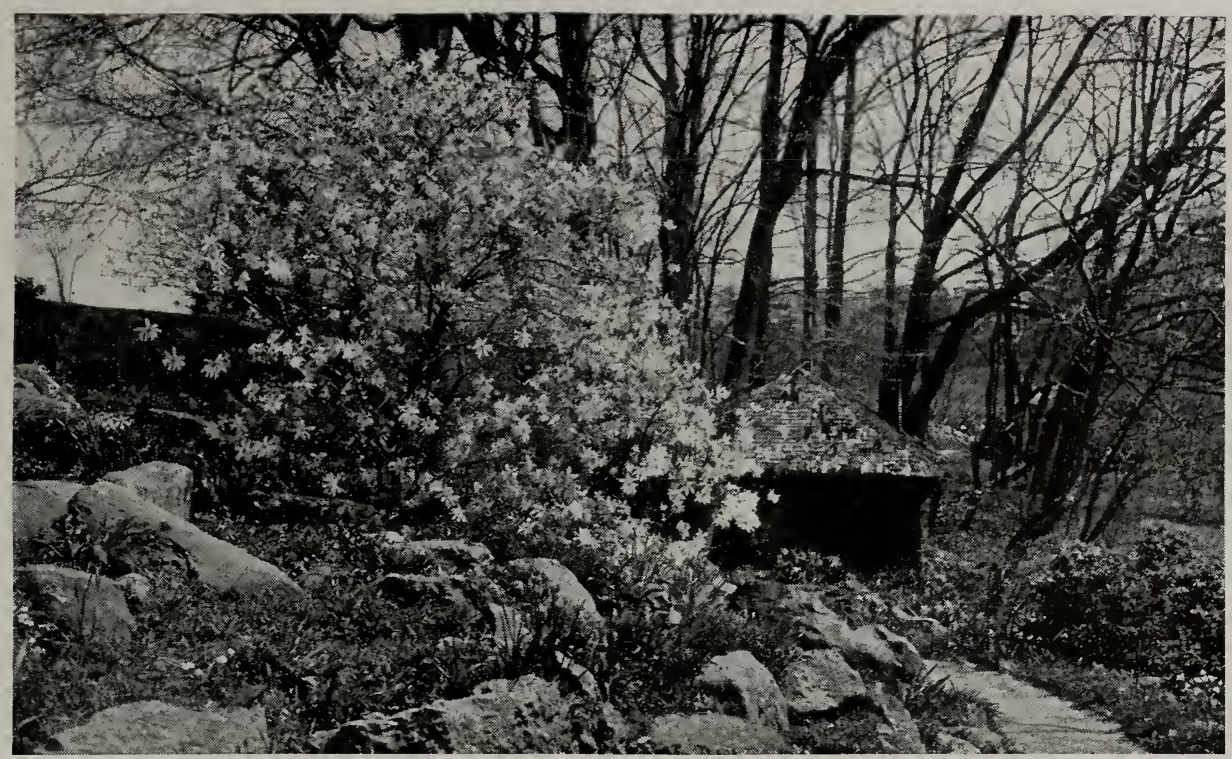

The Magnolias blooming with the earliest spring bulbs in the rock-garden

\section{Magnolias}

Magnolia

The splendor and magnificence of the blossoms of the stately Magnolias are not rivaled by any other flower. Almost over night, after a few warm days in early spring, the plants appear suddenly some morning absolutely covered, as if by enchantment, with great gorgeous flowers. They seem to typify, wherever they may be, in the border or overhanging the garden, the Iuxury of spring and approaching summer.

\section{SEE, ALSO, FLOWERING TREES, PAGE 85}

\section{Soulange's Magnolia}

Magnolia soulangeana

Vigorous-growing and developing into a small tree, usually with several stems; deep, goblet-shaped white flowers, pink inside, in April.

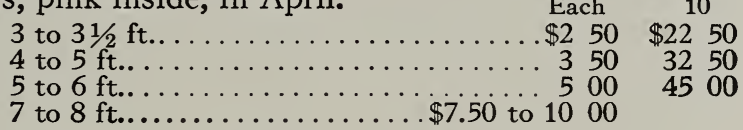

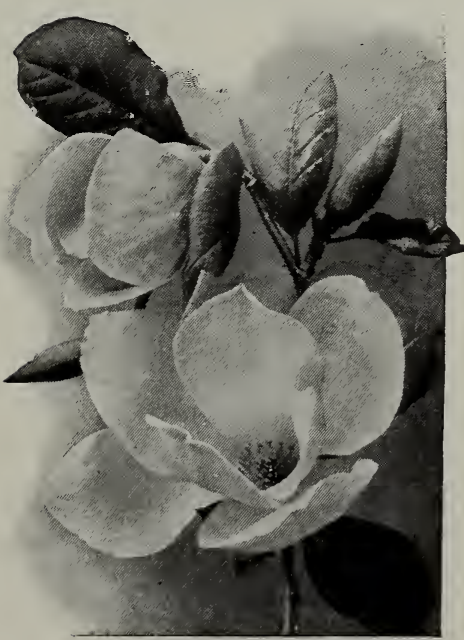

Flowers of Magnolia soulangeana

\section{Soulange's Purple Magnolia}

Magnolia soulangeana, var. nigra

Similar in habit; flowers dark purple on the outside.

Each 10

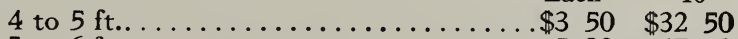

5 to $6 \mathrm{ft} . \ldots \ldots \ldots \ldots \ldots \ldots \ldots \ldots \ldots \ldots \ldots \ldots \ldots \ldots \ldots \ldots, 500,4750$

\section{Lenne's Magnolia}

Magnolia soulangeana, var. Lennei

The flowers are a rich, deep purple on the outside and appear a little Iater than the above. It also gives a few blooms during the summer and early fall.

\begin{tabular}{|c|c|}
\hline $\begin{array}{l}4 \text { to } 5 \mathrm{ft} . . \ldots \ldots \ldots \ldots \\
5 \text { to } 6 \mathrm{ft.} . \ldots \ldots \ldots \ldots \\
7 \text { to } 9 \mathrm{ft} . \text { Specimens }\end{array}$ & $\begin{array}{r}\text { Each } \\
. \$ 350 \\
.500 \\
.75\end{array}$ \\
\hline
\end{tabular}




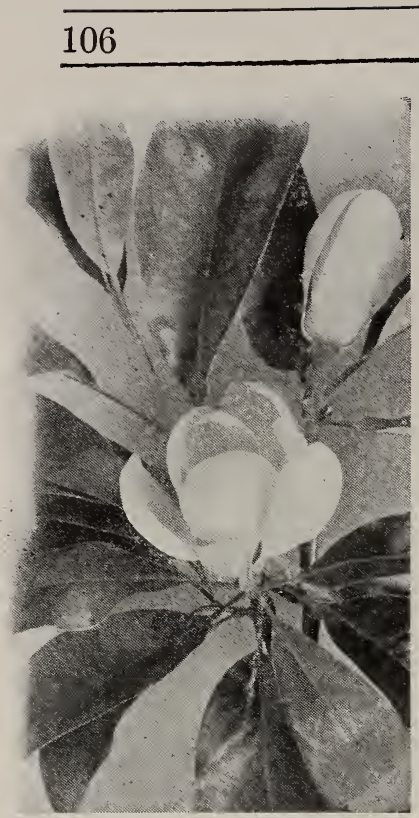

Sweet Magnolia blossoms

\section{Showy-Flowered Magnolia}

Magnolia speciosa

The flowers are a little lighter in color and appear much Iater than the $M$. soulangeana, which it resembles in habit of growth.

Each 10

5 to $6 \mathrm{ft}$

$\$ 500$

$\$ 4500$

\section{Large White Chinese Magnolia Magnolia alba superba}

The bloom is Iarger than that of $M$. speciosa.

Each

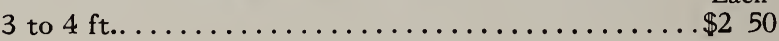

\section{Sweet Magnolia}

Magnolia glauca

One of the most delightful, handsome shrubs of which any garden can boast. The leaves are long and narrow, glossy dark green above and silvery green beneath, and have the substantial appearance of an evergreen leaf. Nestling in this handsome foliage for several weeks in June are found the Iovely, cup-shaped, waxy cream-white flowers, which possess a most exquisitely delicate perfume. The blossoms are followed in turn by clusters of bright orange-red fruits during July and August. We cannot too highly recommend this hardy shrub.

\begin{tabular}{rrrr}
\multicolumn{2}{c}{ Each } & \multicolumn{2}{c}{10} \\
$\$ 2$ & 00 & $\$ 18$ & 50 \\
3 & 00 & 28 & 50 \\
3 & 50 & 33 & 50
\end{tabular}

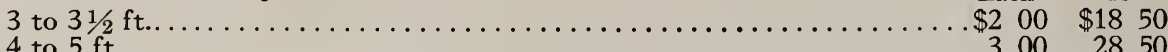

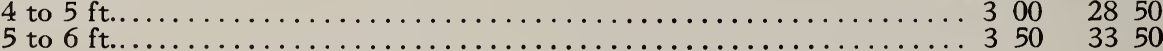

Purple Magnolia

Magnolia obovata

A native of China and Japan, forming a handsome shrub, bearing large cup-shaped flowers, purple outside and nearly white within; Iater than the other Magnolias in blooming.

5 to $6 \mathrm{ft}$.

Each $\$ 350$

\section{Starry Magnolia}

Magnolia stellata (halleana)

A slow-growing, hardy, Iarge shrub with spreading branches and dark green leaves. Its greatest charm is the profusion of blossoms from which it gets its name. In earliest spring, before the leaves appear, it seems a bewildering shower of waxy white, sweet-scented, star-shaped blossoms about 3 inches across.

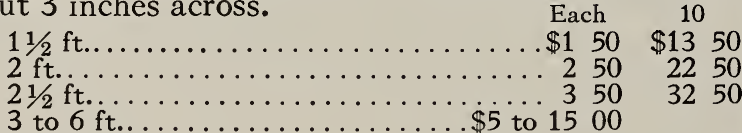

\section{Dwarf Horse-Chestnut}

\section{Asculus parviflora (Pavia macrostachya)}

One of the handsomest, ornamental, hardy shrubs, slow-growing to an eventual height of 6 or 8 feet. It is most often planted in large groups by itself to give it ample chance for development without crowding. In spring it bears a profusion of narrow spikes of creamy white flowers about a foot long. Each

$2 \mathrm{ft} . \ldots \ldots \ldots \ldots \ldots \ldots \ldots 100$

$$
21 / 2 \mathrm{ft} \text {. }
$$

100

$\$ 7500$ 9000

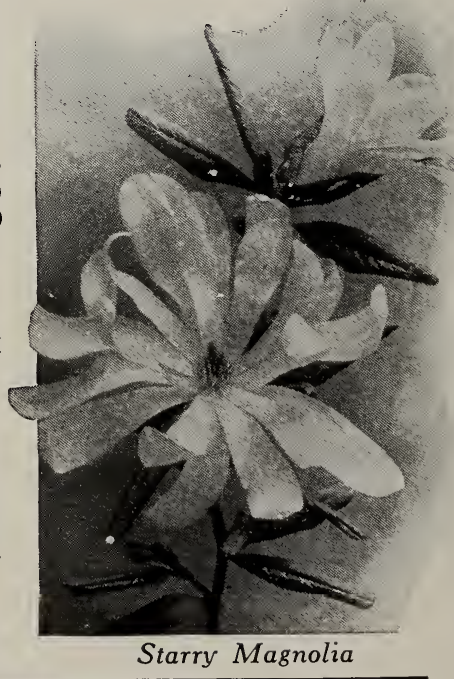

Starry Magnolia 


\section{Japanese Red-Bud Cercis japonica}

In earliest spring, before the leaves appear, this shapely shrub is a mass of rose-pink flowers of great beauty; it is wonderfully effective when seen against an evergreen background. It has Iarge, heart-shaped leaves. These plants are especially broad and bushy.

Each

2 to $21 / 2 \mathrm{ft}$. Heavy.....\$0 50

$21 / 2$ to $3 \mathrm{ft} . . \ldots \ldots \ldots \ldots$

75

$10 \quad 100$

$\$ 450 \quad \$ 3500$

4 to $5 \mathrm{ft}$. Specimens...

$600 \quad 5000$

\section{Lilacs}

\section{Syringa}

Besides the common, old-fashioned Lilac and its many beautiful hybrid varieties, there is a class of Lilacs not widely known but worthy of a better acquaintance, a number of which we list below. These give us both large and small trusses of bloom, the individual flowers being smaller and daintier, the whole effect that of a lighter bloom.

\section{Japanese Lilac}

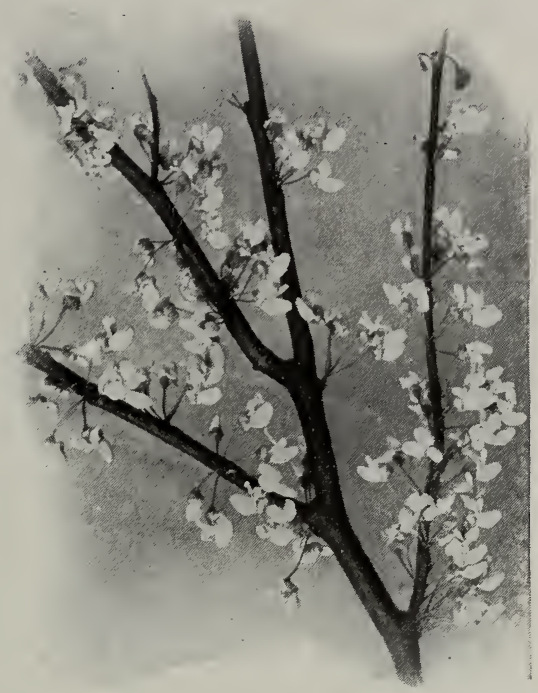

Japanese Red-Bud

Syringa japonica

This eventually forms a small pyramidaI tree or tall shrub with broad leaves, and bearing large panicles of yellowish white blossoms in June or July.

3 to $4 \mathrm{ft}$

Each 10

$\begin{array}{lll}\$ 1 & 00 \quad \$ 7 & 50\end{array}$

Hungarian Lilac

Syringa josikæa

A tall, vigorous shrub with dark green, shining leaves; the panicles of dark violet flowers are borne after the other Lilacs have faded.

3 to $3 \frac{1}{2}$

Each 10

4 to $5 \mathrm{ft}$.

.\$0 $50 \$ 400$

Zabel's Hungarian Lilac

Syringa josikæa, var. H. Zabel

Its flowers are Iarger, pink in the bud and Iilac-red when opened.

Each 10

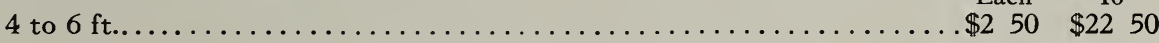

\section{White Persian Lilac}

Syringa persica, var. alba

A graceful shrub with slender, arching branches, on which the fragrant white flowers are borne in May and June.

Each 10

2 to $3 \mathrm{ft}$

.$\$ 050$

$\$ 400$

\section{Himalayan Lilac}

Syringa villosa

A vigorous, upright-growing shrub with large, bright green leaves and bearing Iarge panicles of pinkish flowers late in May.

Each 10

6 to $8 \mathrm{ft}$. Specimens.

$\$ 350$

$\$ 3250$

\section{Emodi's Himalayan Lilac}

Syringa villosa, var. Emodi

Loose panicles of whitish flowers, after the other sorts are faded. One of the really valuable sorts by reason of its very late period of bloom, flowering when the thought of "Lilac" is passed.

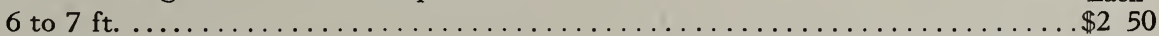

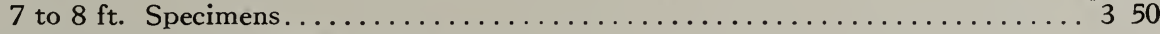




\section{Named Lilacs}

Syringa vulgaris

These Hybrids are far superior to the Common Lilac on account of the richness of their coloring and the large size of the panicles of handsome flowers. The following will be found a splendid assortment, the range of color being from white to deep maroon and purple.

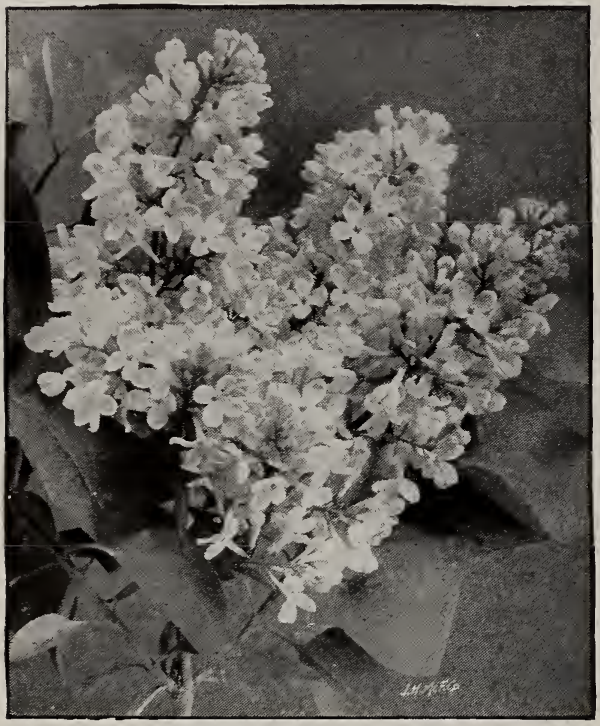

Marie Legraye Lilac
Alphonse Lavalle. Deep Iilac. Each 3 to $4 \mathrm{ft} . . . \ldots \ldots \ldots \$ 100$ $\$ 750$

Charles X. Single; reddish purple. 2 to $21 / 2 \mathrm{ft}$. $\$ 30$ per 100 . . 3 to $4 \mathrm{ft} . . \$ 50$ per $100 \ldots \quad 75600$

Colmariensis. Blue.

3 to $4 \mathrm{ft}$. Heavy. ..... 100750

Congo. Single; wine-red.

$2 \frac{1}{2}$ to $31 / 2 \mathrm{ft}$.......... $75 \quad 600$

Docteur Masters. Double; lilac. 3 to $4 \mathrm{ft}$. Heavy. $100 \quad 750$

Dame Blanche. Double; white. 3 to $4 \mathrm{ft}$.... $100 \quad 750$

Edouard Andre. Double; pink. 2 to $2 \frac{1}{2} \mathrm{ft}$..... 100750

Frau Bertha Dammann. Single; white.

2 to $3 \mathrm{ft}$............. $50 \quad 400$

3 to $4 \mathrm{ft} ., \ldots \ldots \ldots \ldots \ldots . .6 \%$. $75 \quad 600$

Jeanne d'Arc. Double; white. 2 to $2 \frac{1}{2} \mathrm{ft}$.... $50 \quad 400$

Languis. Single; rosy lilac.

2 to $2 \frac{1}{2} \mathrm{ft} . \ldots \ldots \ldots \ldots 100 \quad 750$

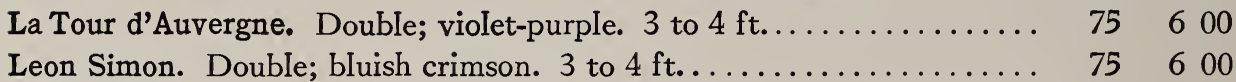

Madame Abel Chatenay. Double; white. 3 to $31 / 2 \mathrm{ft} . \ldots \ldots \ldots \ldots \ldots \ldots 1501350$

Madame Casimir Perier. Double; cream. 2 to $3 \mathrm{ft} . \ldots \ldots \ldots \ldots \ldots . \ldots 50 \quad 400$

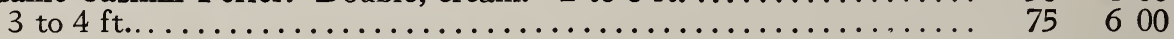

Madame Lemoine. Double; white. 2 to $21 / 2 \mathrm{ft} \ldots \ldots \ldots \ldots \ldots \ldots \ldots . \ldots \ldots$. $50 \quad 400$

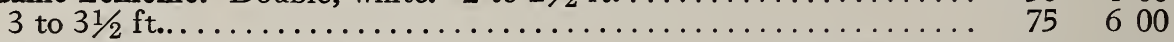

Marie Legraye. Single; white. 2 to $21 / 2 \mathrm{ft} . \ldots \ldots \ldots \ldots \ldots \$ 35$ per $100 \ldots 50 \quad 450$

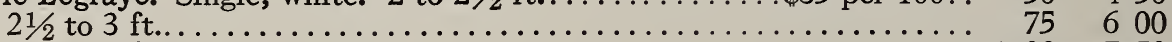

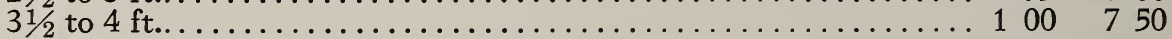

Marc Micheli. Double; lilac-blue. 3 to $4 \mathrm{ft} . \ldots \ldots \ldots \ldots \ldots \ldots \ldots \ldots . \ldots \ldots$

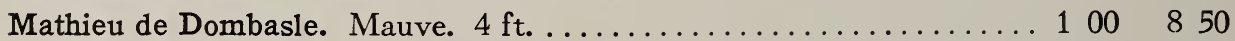

Michael Buchner. Double; pale lilac. 2 to $3 \mathrm{ft} \ldots \ldots \ldots \ldots \ldots \ldots \ldots 100750$

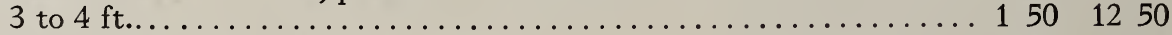

President Grevy. Double; blue. 3 to $4 \mathrm{ft} . \ldots \ldots \ldots \ldots \ldots \ldots \ldots \ldots \ldots . \ldots \ldots$. $75 \quad 600$

President Loubet. Double; reddish carmine. 3 to $4 \mathrm{ft} . \ldots \ldots \ldots \ldots \ldots . \ldots 75 \quad 600$

Rubra de Marley. Single; reddish purple. 2 to $3 \mathrm{ft} . \ldots \ldots \ldots \ldots \ldots \ldots$........ $50 \quad 400$

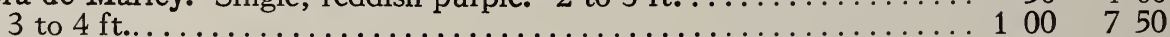

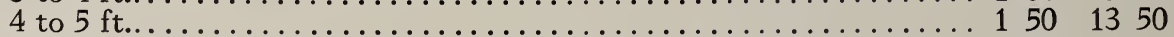

Senateur Volland. Double; rosy red. 2 to $3 \mathrm{ft} . \ldots \ldots \ldots \ldots \ldots \ldots \ldots . \ldots . \ldots 50 \quad 400$

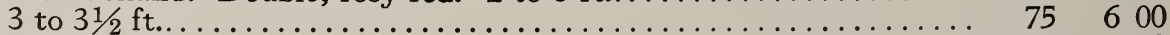

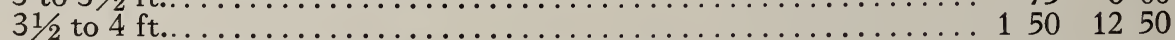

Souvenir de Ludwig Spaeth. Single; red. 2 to $21 / 2 \mathrm{ft} \ldots \ldots \ldots \ldots \ldots \ldots 50 \quad 400$

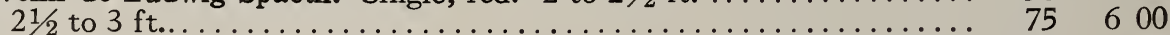

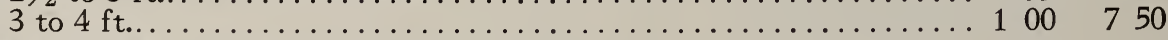

Ville de Troyes. Single; dark purple. 2 to $3 \mathrm{ft}$.............. 75 


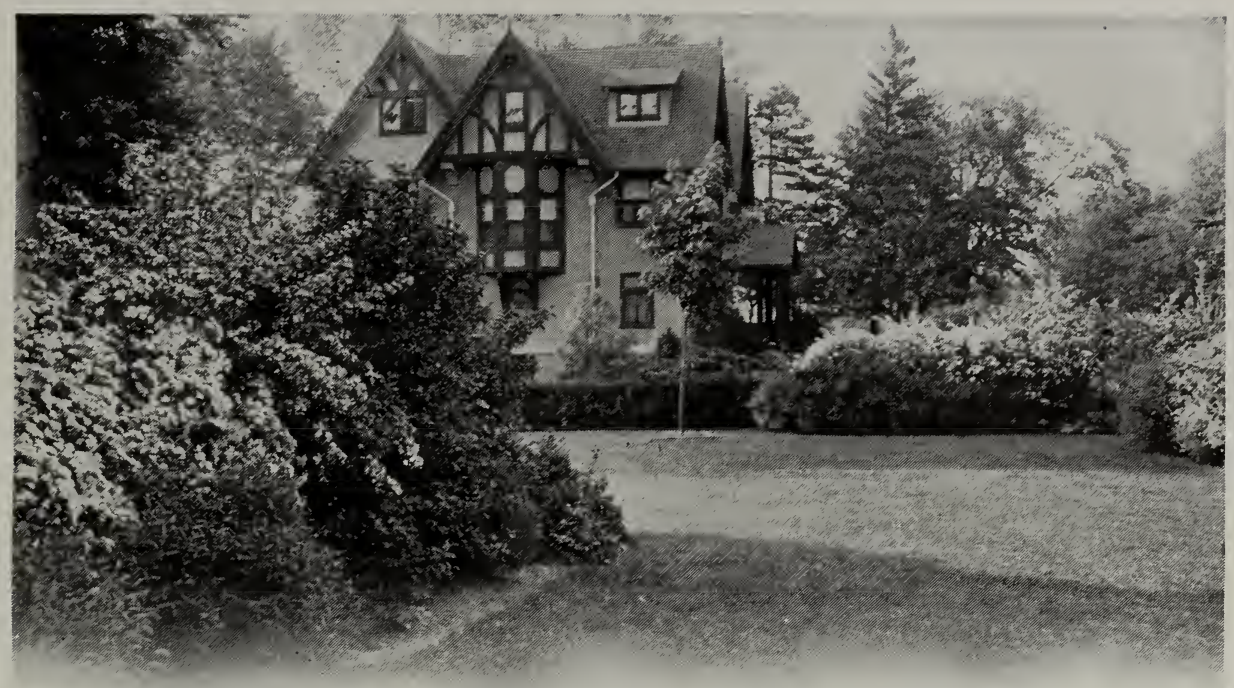

\section{Shrubs for Spring Effects. Spring Flowers in the Shrubbery}

7 HROUGH the winter's cold we enjoy the promise of spring that is held out by the tiny closed buds and bright twigs of the deciduous shrubs, and this promise is amply fulfilled, especially by the earliest flowering sorts. It seems as though some of them clothe their bare limbs overnight to dazzle us next day with the beauty of their gay apparel of abundant flowers.

These shrubs furnish us a varied list to choose from, for shrubbery borders, screen plantings of medium height, and well-formed specimens. Not only are they valuable on account of their spring flowers, but many of them furnish us with rich foliage effects in midsummer, later add the charm of attractive berries in fall, and lend warmth to the winter landscape with their bright-colored twigs. These latter are especially effective, as are also the earliest flowering sorts when planted in combinations with evergreens, which serve as an admirable background for them.

Bush Aralia Acanthopanax spinosus (Aralia pentaphylla)

Holds its dark green leaves till late in the fall, making it valuable for screen planting; flowers inconspicuous yellowish green.

3 to $4 \mathrm{ft}$

Each

Each $10 \quad 100$

Dwarf June Berry

Amelanchier botryapium

Pretty red fruit follows the bloom of white flowers.

2 to $3 \mathrm{ft}$

Each 10

$10 \quad 100$

3 to $4 \mathrm{ft}$

Service Berry

Amelanchier vulgaris

Each $10 \quad 100$

NO CHARGE FOR PACKING 


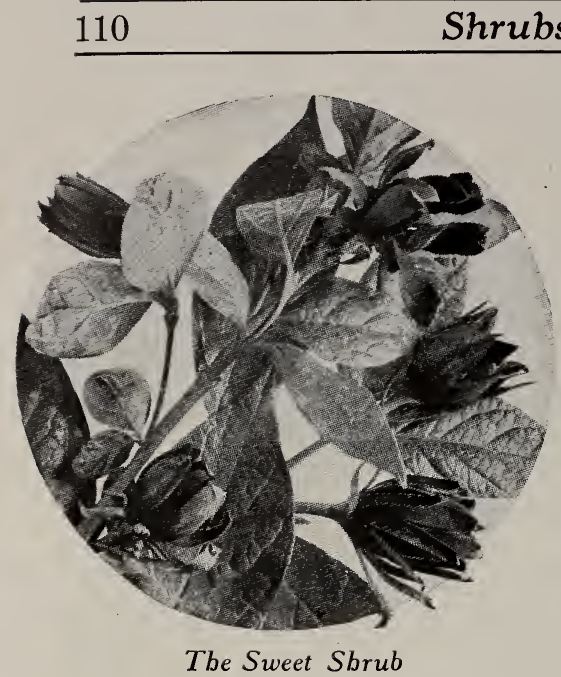

Japanese Sweet Shrub
Japanese Quince Cydonia japonica

Makes a handsome specimen or is good for massing.

$11 / 2 \mathrm{ft}$., separate colors

Allspice, or Sweet Shrub

\section{Calycanthus floridus}

This shrub is best known as the Sweet Shrub. Its chocolate-colored blossoms have a rich, spicy odor and it is especially valuable in plantings near the house or in the borders where one is apt to have a garden seat, as the perfume is exceedingly rich, especially in the early morning and late evening when the dew is on the plant.

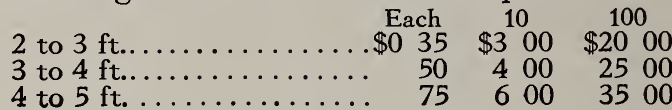

\section{Calycanthus præcox} Each 10

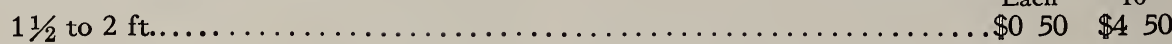

\section{Siberian Pea}

Caragana arborescens

An upright-growing shrub of great hardiness, bearing bright yellow flowers in great profusion. The bloom is somewhat smaller but the shape is that of a sweetpea blossom. These are particularly attractive against the small, deep green foliage.

4 to $6 \mathrm{ft}$.

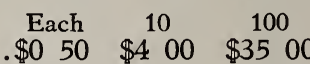

\section{White Fringe}

Chionanthus virginica

Most desirable for its white blossoms which make it seem a cloud of snowy Iace against the rich deep green foliage. While this is not a rapid-growing shrub, it attains a height of 8 to 10 feet and should be given a prominent place for specimen effect.

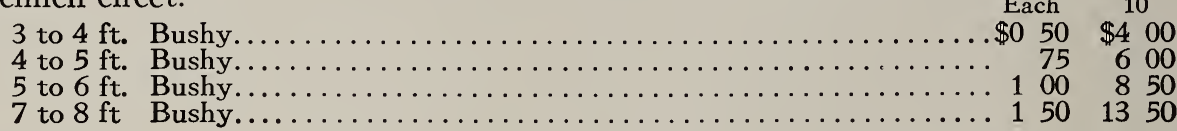

Hardy Orange

Citrus trifoliata

A vigorous bush; foliage glossy green; flowers white; its orange-colored fruits, the size of a golf-ball, are very ornamental.

2 to $3 \mathrm{ft}$

Each

10

$\$ 0 \quad 50 \$ 400$

Single Globe Flower (Kerria)

Corchorus japonicus

Bright green foliage; Iarge yellow blossoms borne continuously through the summer. 4 to 6 feet.

Each 10

2 to $3 \mathrm{ft}$.

$\$ 0 \quad 50 \$ 400$

Double Globe Flower

Corchorus japonicus, var. flore-pleno

Produces double, deep orange flowers in spring and summer; lovely green twig effect in winter.

Each 10

$1 \frac{1}{2}$ to $2 \mathrm{ft}$

.$\$ 050 \quad \$ 400$

Variegated-leaved Globe Flower Corchorusjaponicus, var.variegata

The foliage is marked with white; flowers yellow.

Each 10

$2 \mathrm{ft}$

.\$0 $50 \$ 400$ 


\section{Dogwood, or Osiers}

Cornus

This family of shrubs is adaptable to use in the shrub border and for screen planting. Attractive not only for the wealth of spring bloom, but fully as much for the abundant berries and leaf coloring in autumn, and especially for the bright twigs which enliven the winter landscape. AII are quick, vigorous growers, perfectly hardy, and the summer foliage-effect is very satisfactory.

SEE, ALSO, TREES, PAGE 81

\section{Siberian Red Osier}

\section{Cornus alba}

Bright red branches; flowers white; fruit blue.

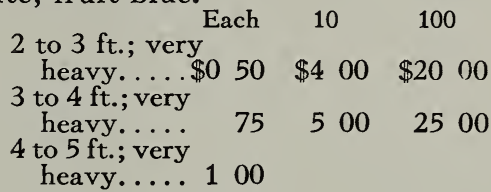

\section{Cornelian Cherry}

\section{Cornus mas}

Bright yellow flowers appear before the leaves in earliest spring; fruit bright scarlet.

3 to $4 \mathrm{ft} \quad$ Each $10 \quad 100$

3 to $4 \mathrm{ft} . . . . \$ 0 \quad 35 \$ 300 \$ 2000$

$\begin{array}{llllll}5 & \text { to } 6 \mathrm{ft} . . . & 50 & 3 & 50 & 2500 \\ & 75 & 6 & 00 & 4000\end{array}$

6 to $8 \mathrm{ft}$.

Specimens. 150125010000

\section{Panicled Dogwood}

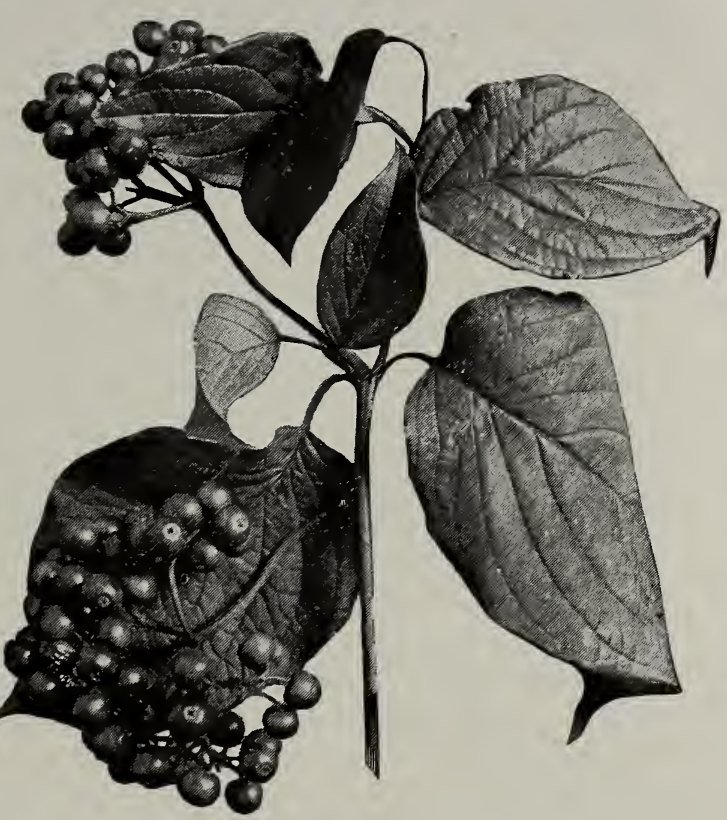

Berries of Siberian Red Osier

An upright, tall-growing shrub, with gray branches; flowers white; fruit white on bright red stems. A very dense twiggy grower, most useful for screening purposes.

3 to $4 \mathrm{ft}$

Each

$10 \quad 100$

4 to $5 \mathrm{f}$

5 to $6 \mathrm{ft}$

European Red Osier

Cornus sanguinea

Of more upright growth than the Siberian form; bright red twigs; black fruit.

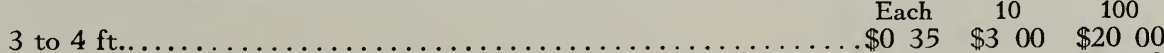

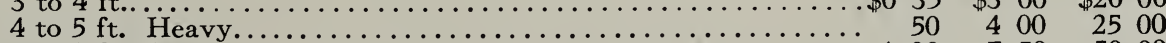

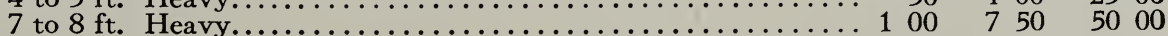

\section{Silky Dogwood}

Cornus sericea

An upright shrub, spreading into thick coverts when planted in groups, making a good game-cover; reddish purple bark; bluish berries of which the birds are very fond.

2 to $3 \mathrm{ft}$

Each

10

100

$31 / 2$ to 4

$\$ 035$

$\$ 300$

$\$ 1500$

4 to $5 \mathrm{ft}$.

$\begin{array}{lll}50 & 4 & 00 \\ 75 & 6 & 00\end{array}$

2000

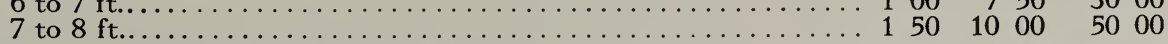


American Red Osier

Cornus stolonifera

Red bark; fine for waterside planting; pretty white flowers.

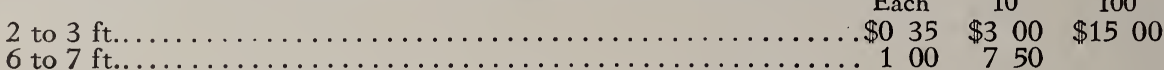

6 to $7 \mathrm{ft}$

Golden-barked Osier

Cornus stolonifera, var. aurea

The bright yellow twigs make a most effective combination with the redtwigged varieties in winter; flowers white.

2 to $3 \mathrm{ft}$

Each $10 \quad 100$

3 to $4 \mathrm{ft} . \ldots \ldots \ldots \ldots \ldots \ldots \ldots \ldots \ldots \ldots \ldots \ldots \ldots \ldots \ldots \ldots \ldots \ldots \ldots \ldots \ldots \ldots \ldots \ldots$
4

$\$ 035$

$\$ 300 \quad \$ 2000$

Scotch Broom

Cytisus scoparius

A good seashore plant; its green twigs give it the appearance of an evergreen in winter. Covered with a profusion of bright yellow flowers in early spring.

Each 10

2 to $3 \mathrm{ft}$

$\$ 350$

\section{Deutzia}

Deutzias

One of the showiest families of shrubs for the abundance of pretty blossoms which cover the plants in spring; very easy of culture. They may be used to equal advantage in the shrub border, in masses or groups, as specimens, or in the garden. The varieties of $D$. crenata may also be used planted as flowering hedges.

Single White Deutzia

Single white flowers; growing to 8 to 10 feet.

Deutzia crenata

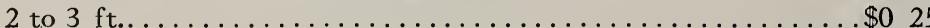

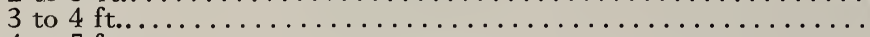

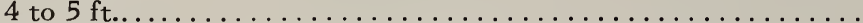

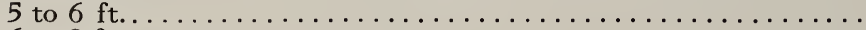

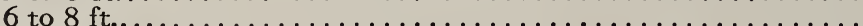

\begin{tabular}{|c|c|c|}
\hline Each & 10 & 100 \\
\hline 502 & $\$ 200$ & $\$ 15$ \\
\hline & 300 & 2 \\
\hline 5 & 400 & 30 \\
\hline & 450 & 35 \\
\hline & 500 & \\
\hline
\end{tabular}

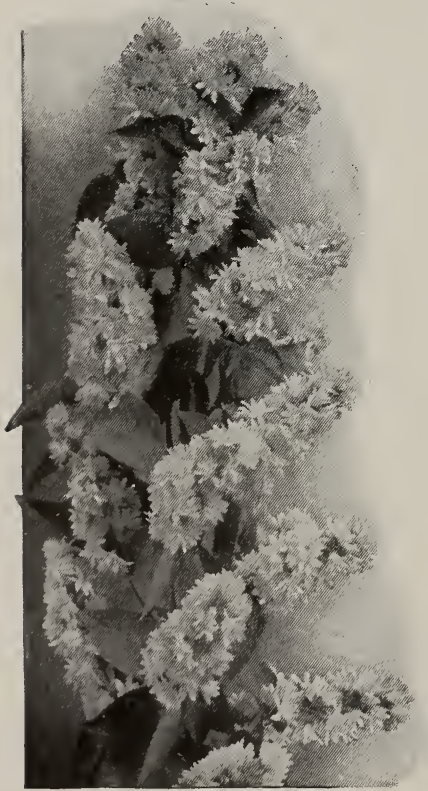

Double White Deutzia
Double White Deutzia

Deutzia crenata, var. candidissima Double white flowers; tall-growing, to 8 feet.

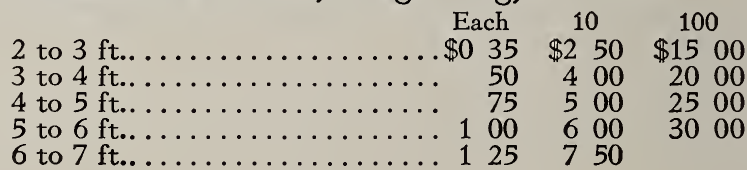

Pride of Rochester

Deutzia crenata, var. Pride of Rochester

Early blooming; double flowers, white tinged with rose; vigorous grower. $\quad$ Each $10 \quad 100$

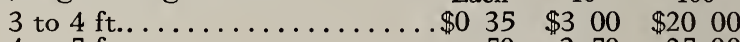
4 to $5 \mathrm{ft} . \ldots \ldots \ldots \ldots \ldots \ldots \ldots \ldots \ldots$ 50 $350 \quad 2500$

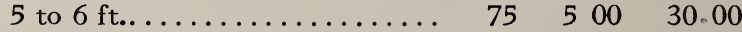

Double Pink Deutzia

Deutzia crenata, var. rosea-plena Rosy white flowers; 7 to 8 feet.

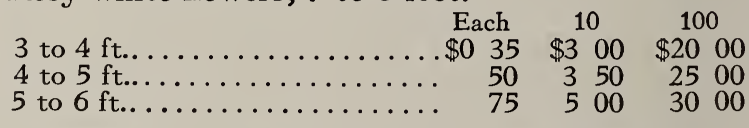




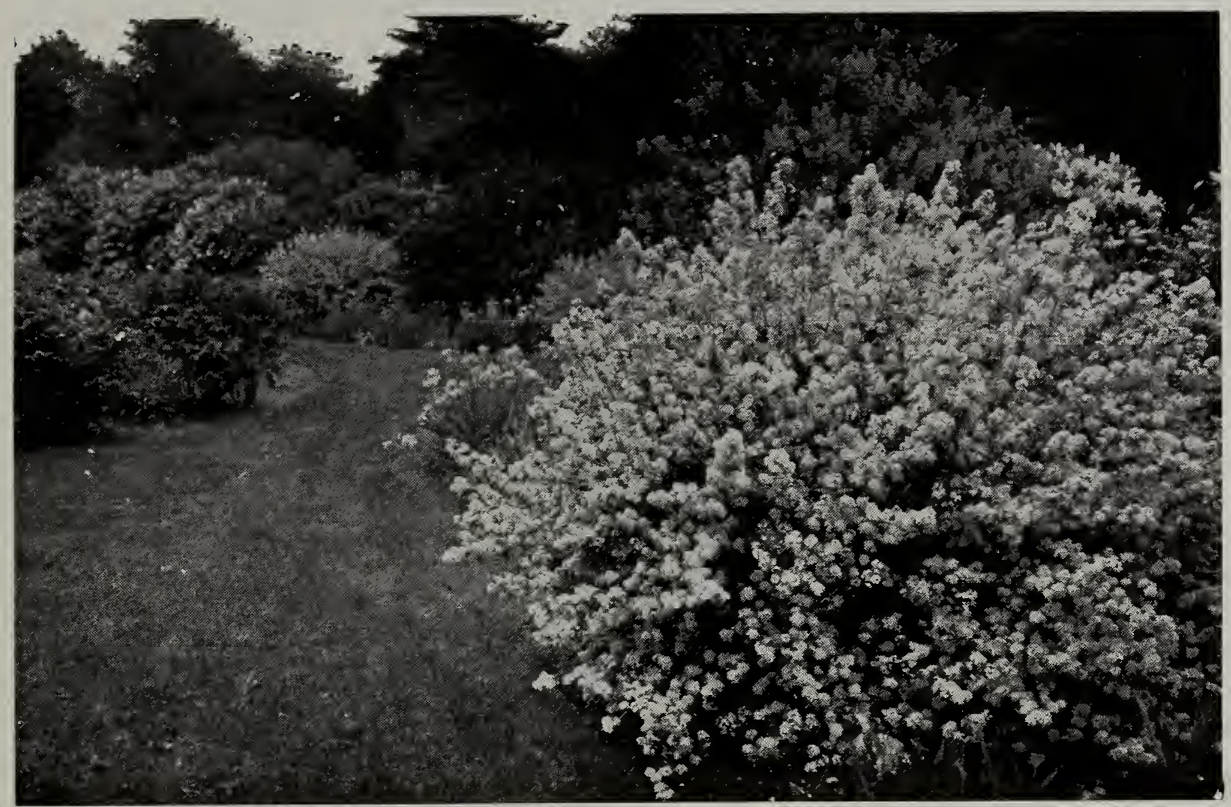

Deutzia lemoinei in full bloom

\section{Waterer's Deutzia}

Deutzia crenata, var. Watereri

Large, double, pink flowers; vigorous, tall shrub.

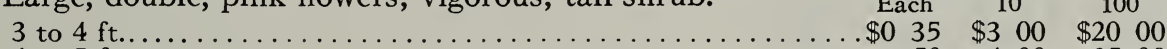

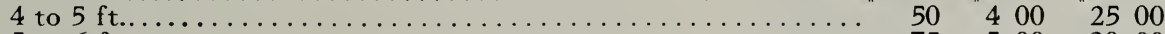

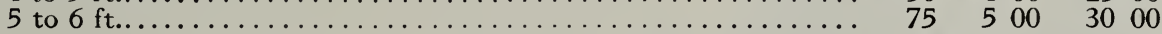

Wells' Deutzia

Deutzia crenata, var. Wellsii

Beautiful single white flowers; vigorous grower.

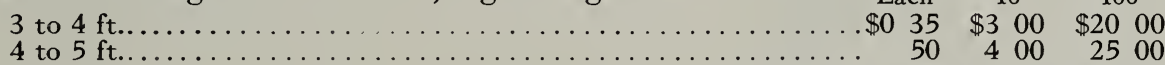

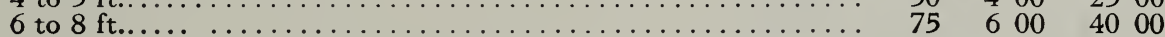

\section{Dwarf Deutzia}

Deutzia gracilis hedge.

Dense-growing, low bush; pretty nodding white flowers; fine for a low, flowering

12 to 15 in

$\begin{array}{lll}\text { Each } & 10 & 100\end{array}$

$11 / 2 \mathrm{ft}$. Heavy.

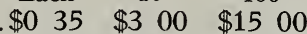

Carmine-flowered Deutzia

Deutzia gracilis, var. carminea

A handsome form with rose-colored flowers; graceful arching branches.

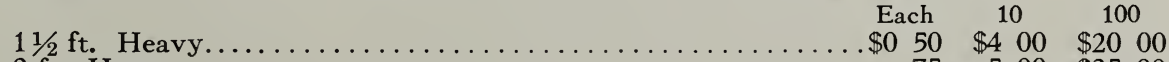

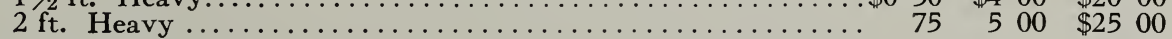

Rose-flowered Deutzia Deutzia gracilis, var. rosea

Particularly graceful, low-arching branches, loaded with pink flowers.

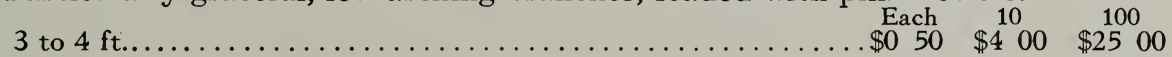

Lemoine's Deutzia

Deutzia lemoinei

Early bloomer of medium height; single white flowers. Each $10 \quad 100$

3 to $4 \mathrm{ft}$. Heavy ................................ $\$ 0 \quad 50 \quad \$ 400 \quad \$ 2500$

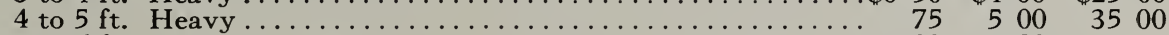

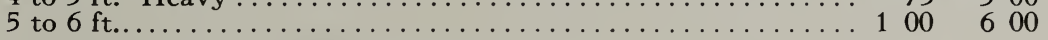

NO CHARGE FOR PACKING 


\section{Compact Deutzia}

Compact-growing form of the preceding.

2 to $21 / 2 \mathrm{f}$

Small-flowered Deutzia

One of the hardiest species; erect, and profuse in its white bloom.

3 to $4 \mathrm{ft}$

$$
\text { Each } 10 \quad 100
$$

$\$ 0 \quad 50 \quad \$ 400 \quad \$ 2500$

Rough-leaved Deutzia

Deutzia scabra

A tall shrub with handsome racemes of pure white flowers.

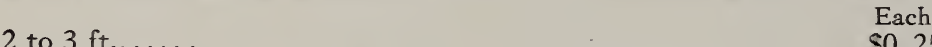

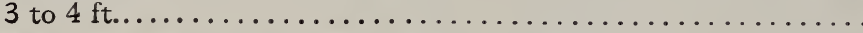

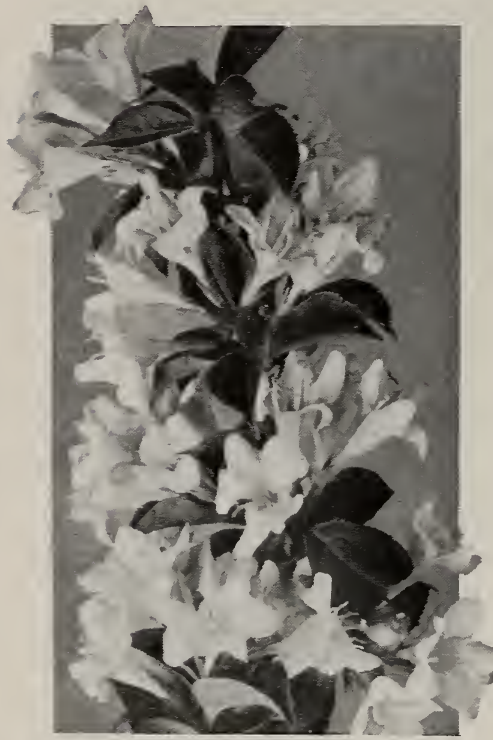

Pink Weigela

\section{Diervilla}

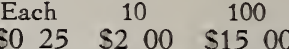
$300 \quad 2000$

\section{Weigela}

Vigorous-growing shrubs, to 6 or 8 feet, of spreading habit; they are among the showiest of shrubs for borders or specimens, and each of the varieties possesses some special attraction in the color of its flowers. No shrub is more useful for cut-flowers for decorations. The long branches are clothed in bloom from end to end.

\section{Pink Weigela}

Diervilla florida (rosea)

Flowers rose-colored.

Each $10 \quad 100$

3 to $4 \mathrm{ft} . . . \ldots \ldots \ldots \ldots \ldots \$ 0 \quad 50 \quad \$ 400 \$ 2500$

Rose Weigela

Diervilla florida, var. amabilis

Each $10 \quad 100$

3 to $31 / 2 \mathrm{ft} . \ldots \ldots \ldots \ldots \ldots . \$ 0 \quad 50 \quad \$ 400 \quad \$ 2500$

White Weigela

Diervilla florida, var. candida Profuse bloomer; flowers pure white.

2 to $3 \mathrm{ft}$. . .

$\begin{array}{rrr}\text { Each } & 10 & 100 \\ \$ 0 \quad 35 & \$ 300 & \$ 2000 \\ \quad 50 & 400 & 2500\end{array}$

4 to $5 \mathrm{ft}$

Diervilla florida nana, var. aurea variegata

Variegated Weigela

eares are bordered with yellow.

Each 10

Dwarf form
2 to $21 / 2 \mathrm{ft}$

$\$ 075 \$ 600$

\section{Crimson Weigela}

Diervilla floribunda, var. Lavallei

Medium height; bright crimson flowers. An abundant bloomer with rich attractive foliage.

3 to $4 \mathrm{ft}$...

Each $10 \quad 100$

4 to $5 \mathrm{ft}$.

S0 35

$\begin{array}{llll} & 100 & \$ 20 & 00\end{array}$

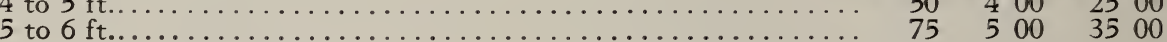

Snow-White Weigela

Diervilla japonica, var. nivea

Of medium height; especially good foliage; flowers pure white.

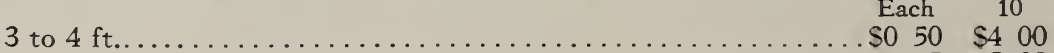

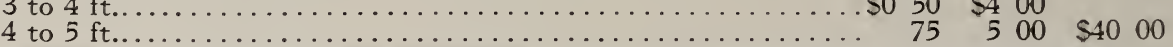


Red Weigela

Deep crimson flowers; good foliage.

3 to $4 \mathrm{ft}$

4 to $5 \mathrm{ft}$

Carmine Weigela

Erect grower; profuse dark carmine flowers.

3 to $4 \mathrm{ft}$..

4 to $5 \mathrm{ft} . \ldots \ldots \ldots \ldots \ldots \ldots \ldots \ldots \ldots$

Hybrid Weigela

Diervilla japonica, var. Gronewegenii Tall-growing; flowers red outside, white within, striped with red.

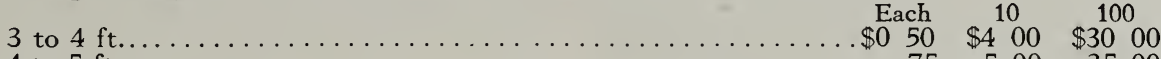

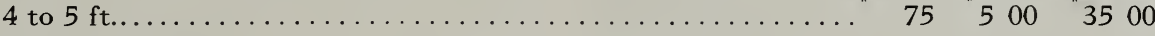

Hybrid Weigela

Diervilla japonica, var. Mad. Coutourier

Medium height; flowers cream-white, tinted with pink.

3 to $4 \mathrm{ft}$

5 to $5 \mathrm{ft}$

Hybrid Weigela

Strong grower; dark red flowers.

3 to $4 \mathrm{ft}$

5 to $6 \mathrm{ft}$

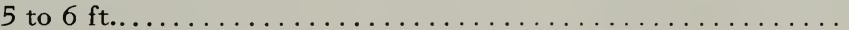

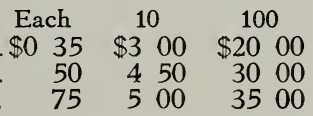

Diervilla japonica, var. Steltzneri

Each $10 \quad 100$

$\$ 0035 \quad \$ 300 \quad \$ 2000$

$\begin{array}{lllll}50 & 4 & 50 & 30 & 00\end{array}$

Hybrid Weigela

Diervilla japonica, var. Van Houttei

Not so tall as the Iast; flowers clear carmine.

4 to $5 \mathrm{ft}$

$\begin{array}{ccc}\text { Each } & 10 & 100 \\ \$ 0 \quad 50 & \$ 450 & \$ 3000\end{array}$

5 to 6

$\begin{array}{lll}75 & 600 & 3500\end{array}$

Hybrid Weigela

Pale pink flowers.

3 to $4 \mathrm{ft}$.

Diervilla japonica, var. Verschaffeltii

4 to $5 \mathrm{f}$

$\begin{array}{lll}\text { Each } & 10 & 100\end{array}$

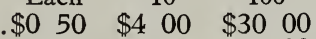
$500 \quad 3500$

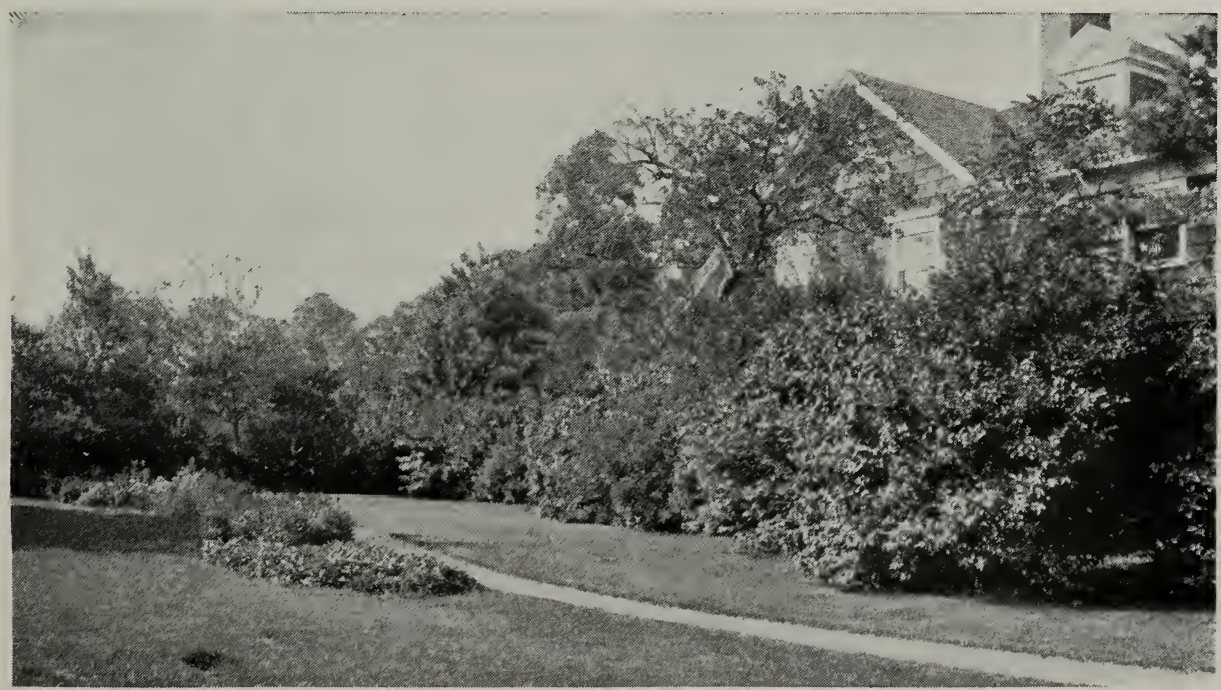

An effective screen of bigh sbrubs wbich also add beauty and interest to the lawn

NO CHARGE FOR PACKING 
Pearl Bush

Exochorda grandiflora

Rapid-growing, tall shrub, covered in May with starry, white blossoms.

2 to $3 \mathrm{ft}$

Each

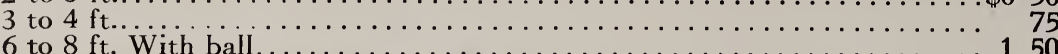

$\$ 050$

$\$ 350$

$\$ 300$

1250

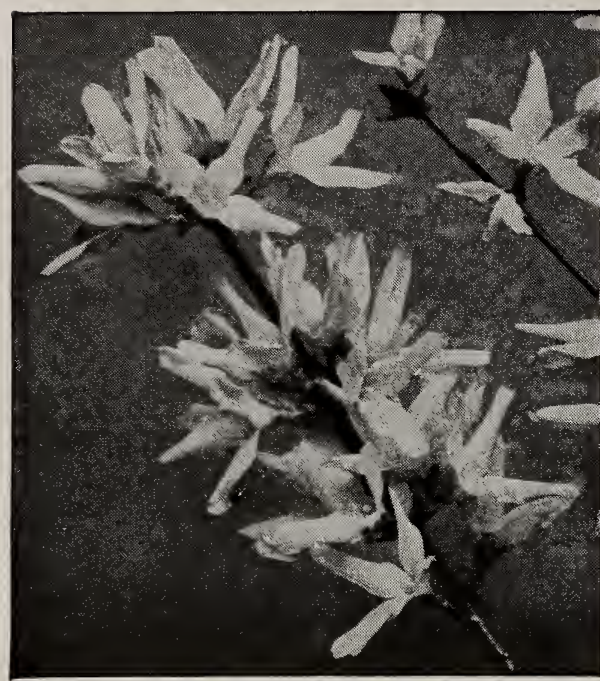

Flowers of Golden-Bell

\section{Golden-Bell}

Forsythia

Among the earliest shrubs to brave the weather and make the border in very early spring a warm spot of golden yellow, long before the leaves appear. When the branches are brought into the house in winter and placed in water, it is only a week or so before the delicate bells of gold appear on the pretty brown stems, which of themselves give a very pleasing winter effect. They are very rapid-growing shrubs of rather more than medium height, except $F$. suspensa, which is of prostrate habit.

\section{Fortune's Golden-Bell}

Forsythia fortunei

Of strong, upright growth; golden yellow flowers.

\begin{tabular}{|c|c|c|}
\hline $\begin{array}{r}\text { Each } \\
. \$ 035 \\
. \quad 50 \\
. \quad 75 \\
.100\end{array}$ & \begin{aligned} \multicolumn{1}{c}{10} \\
$\$ 250 \\
300 \\
400 \\
600\end{aligned}$ & $\begin{array}{r}100 \\
\$ 1500 \\
1750 \\
2000 \\
3000\end{array}$ \\
\hline
\end{tabular}

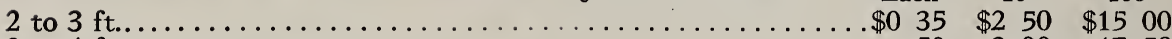

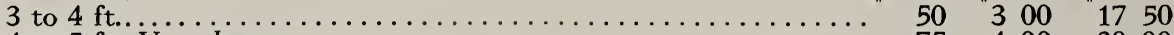

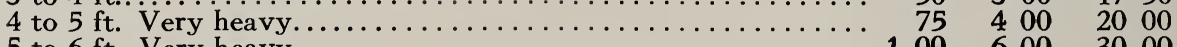

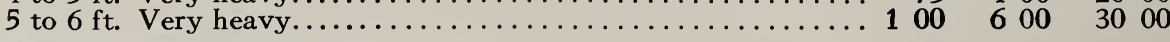

Variegated-leaved Golden-Bell

Forsythia fortunei, var. aurea variegata

Same habit and flower as above; leaves variegated. Each $10 \quad 100$

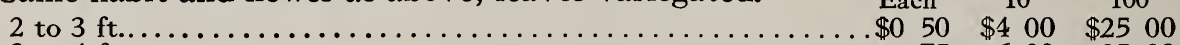

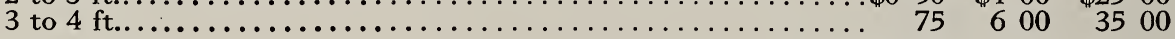

Golden-Bell

Forsythia intermedia

Slender, arching branches from upright stems make this a very graceful-appearing shrub. It has bright golden yellow flowers, as have all the other varieties.

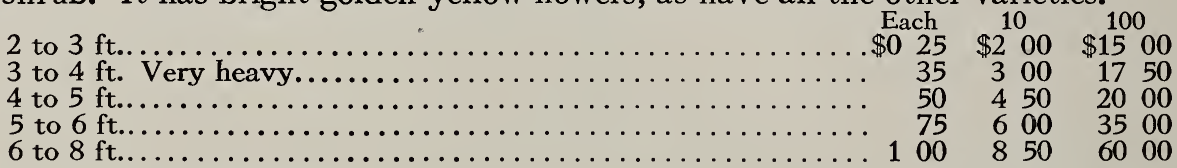

Drooping Golden-Bell

Forsythia suspensa

Spreading into a pretty, low tangle, this shrub is particularly adapted to planting at the top of a retaining wall or on a bank. Each $10 \quad 100$

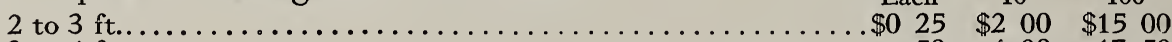

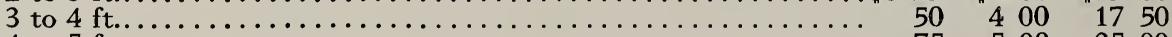

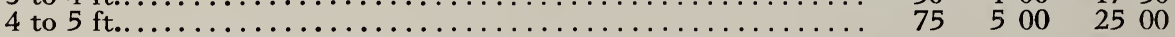

Green-twigged Golden-Bell

Forsythia viridissima

The young twig-growth is interesting for its good green color; strong-growing but not absolutely hardy north of Long Island.

Each $\quad 10 \quad 100$

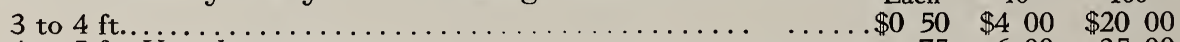

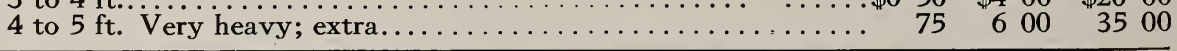


Japanese Witch-hazel

Hamamelis japonica

A mist of airy, purple flowers in early spring; fine in the woods or border.

2 to $3 \mathrm{ft}$.

Each
$\$ 050$

$10 \quad 100$

3 to $4 \mathrm{ft}$

75

$\$ 450 \quad \$ 3500$

4 to $5 \mathrm{f}$

$600 \quad 5000$
850

$\begin{array}{lll}850 & 7500\end{array}$

Virginia Willow

Itea virginica

Free-flowering, low shrub; white fragrant flowers; the fall coloring of crimson makes it even more interesting in the border or along the waterside.

2 to $3 \mathrm{ft}$

Each

6 to $7 \mathrm{ft}$

$\$ 035$

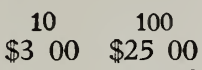

$600 \quad 5000$

\section{Yellow Jasmine}

Jasminum nudiflorum

If you have a very warm, sunny corner, in which to plant this shrub, you will be rewarded by yellow blossoms appearing as early as February. It may be trained against a wall.

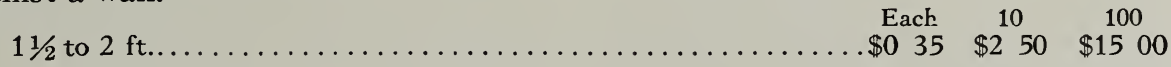

\section{Privet}

Ligustrum

These shrubs received the common name, Privet, in the days of early English gardening, on account of being planted as hedges or screens about gardens to insure privacy, the words being nearly synonymous at that time. There are no shrubs which are better for a quick-growing screen, as they are nearly aII of upright growth and retain their dark green foliage well into the winter. All varieties stand clipping into hedge-form if desired. Many varieties, equally adapted to trimming, are much hardier north of New York than the California Privet, commonly used for hedges.

\section{Amoor River Privet}

Ligustrum amurense

Nearly evergreen in the latitude of Washington, and equally hardy with California Privet; upright grower; white flowers.

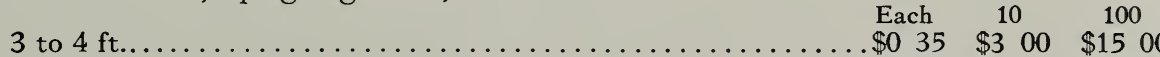

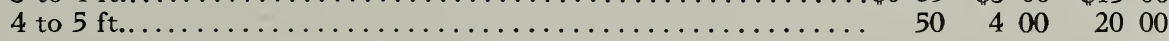

Bright-fruited Privet

Ligustrum ciliatum

Tall, upright, vigorous grower, making it one of the best for screening shrubberies or hedges.

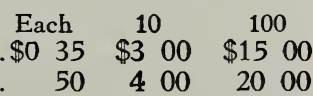

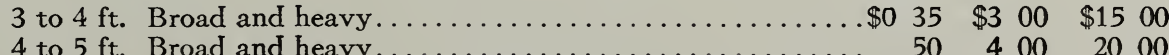

5 to $6 \mathrm{ft}$. Broad and heavy.............................. $75 \quad 6 \quad 50 \quad 3500$

\section{Ibotan Privet}

\section{Ligustrum ibota}

Our stock is the true, upright, tall-growing form, with pretty white flowers in tiny lilac-like heads, followed by black berries; one of the best for the shrub border. This variety and all the Privets, in fact, thrive much better in shady places than most other shrubs.

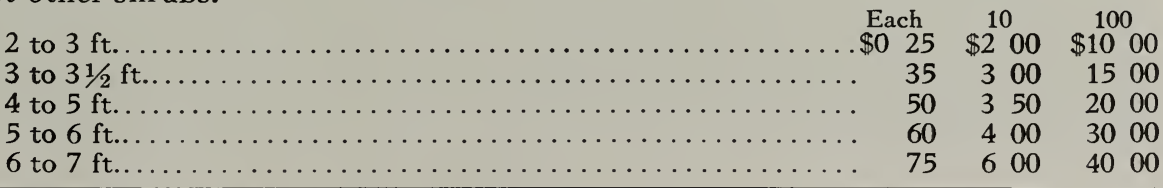

NO CHARGE FOR PACKING 


\section{Regel's Privet}

Ligustrum ibota, var. Regelianum

A low-growing plant, with spreading horizontal branches, white flowers and black fruit. Our stock is true to name and grown from cuttings, not from seed. This keeps the trim prostrate type as introduced, and not the half-upright type cheaply grown from seed and therefore reverting more or less to its parent, the Ibota.

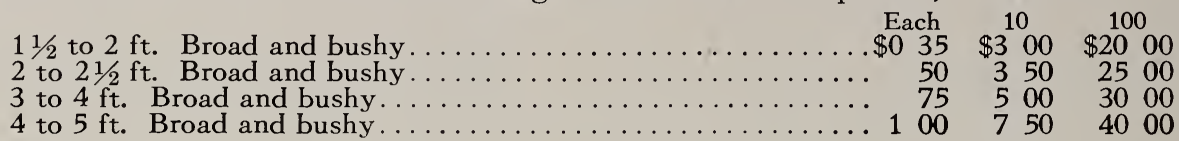

Tall Privet

Ligustrum medium

A strong-growing, vigorous, bushy shrub, with pretty white flowers and black fruit.

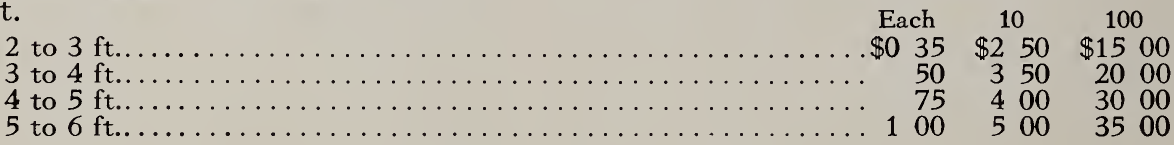

Califorina Privet

Ligustrum ovalifolium

One use to which this well-known, rapid-growing plant is not usually put is in informal screen planting, where it is of great value for its late green foliage in early winter. The plants we offer are extra bushy and it does not require as many plants to obtain a fine, thick hedge as in the case of most stock offered, which has

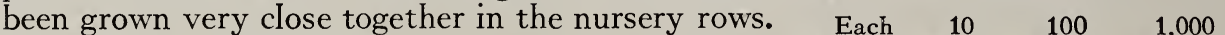

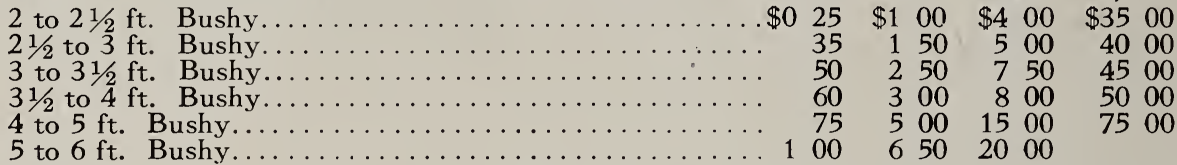

\section{Golden Privet}

\section{Ligustrum ovalifolium, var. aureum}

Pretty, golden, variegated foliage.

10

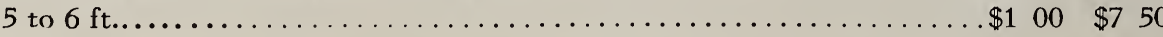

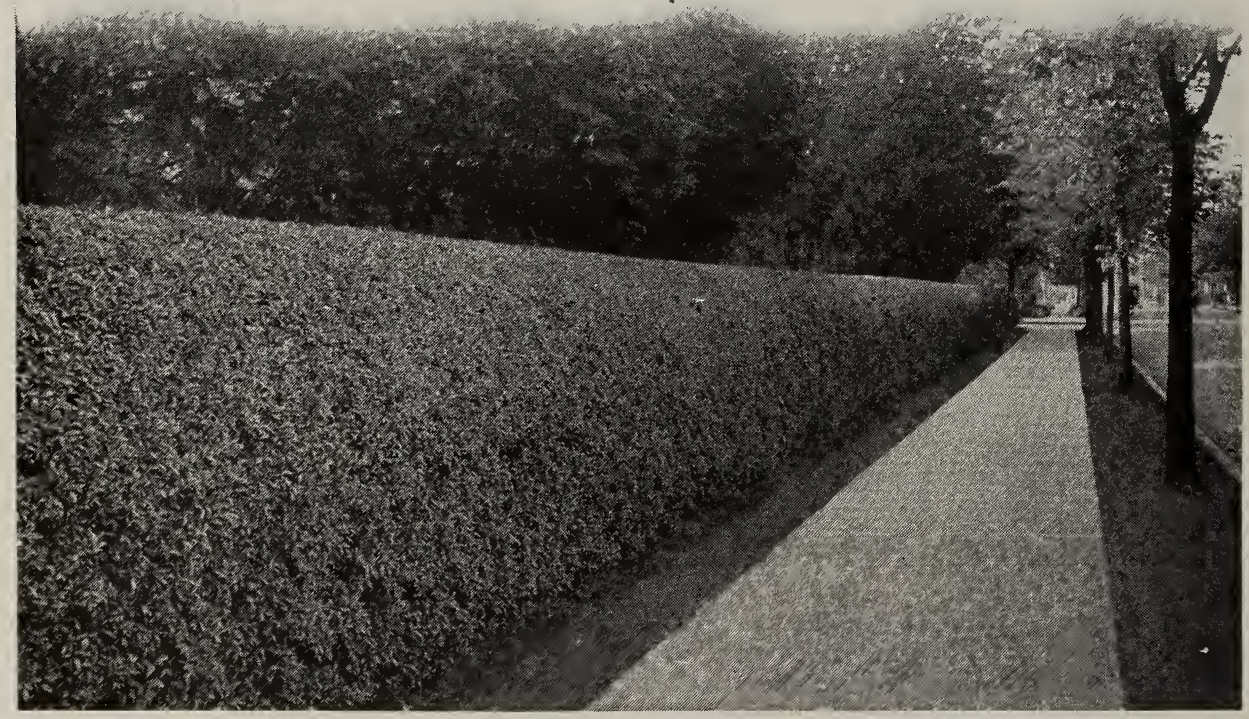

Hedge of California Privet 
Chinese Privet

Ligustrum sinense

A handsome plant, with spreading, slender branches; white flowers followed by dense clusters of black berries.

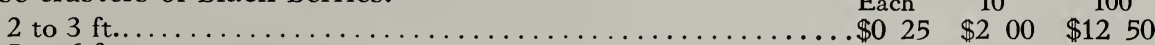

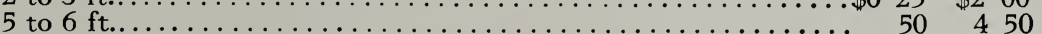

European Privet, or Prim

Ligustrum vulgare

Admirable for situations too shady for most shrubs; a good border plant of medium height.

2 to $3 \mathrm{ft}$.

$\begin{array}{lll}\text { Each } & 10 & 100\end{array}$

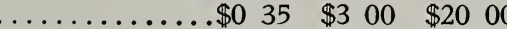

\section{Bush Honeysuckles}

\section{Lonicera}

These vigorous, tall-growing shrubs comprise a group invaluable in border or mass planting; or, if trimmed, they will form a close, twiggy, flowering hedge. The abundance of spring bloom is followed by showy red berries appearing in summer and continuing till early fall. The different varieties of the Tartarian Honeysuckle all present interesting forms of handsome flowers and all are absolutely hardy.

Chinese Fragrant Bush Honeysuckle Lonicera fragrantissima

Creamy white, fragrant flowers in earliest spring; rather wide-spreading habit.

Each $10 \quad 100$

$\begin{array}{rlrrrr}2 & \text { to } 3 \mathrm{ft} . \ldots \ldots \ldots \ldots \ldots \\ 3 \text { to } 4 \mathrm{ft} . \ldots \ldots \ldots \ldots & 55 & \$ 3 & 25 & \$ 2500 \\ \end{array}$

\section{Japanese Bush Honeysuckle}

\section{Lonicera morrowii}

Medium height; pure white flowers.

\begin{tabular}{lrrrr} 
& \multicolumn{2}{c}{ Each } & \multicolumn{1}{c}{10} & 100 \\
2 to $3 \mathrm{ft}$. Heavy. $\$ 0$ & 35 & $\$ 300$ & $\$ 1500$ \\
3 to $4 \mathrm{ft} . \ldots \ldots \ldots \ldots$ & 50 & 400 & 2500 \\
4 to $5 \mathrm{ft} . \ldots \ldots \ldots \ldots$ & 75 & 600 & 3500
\end{tabular}

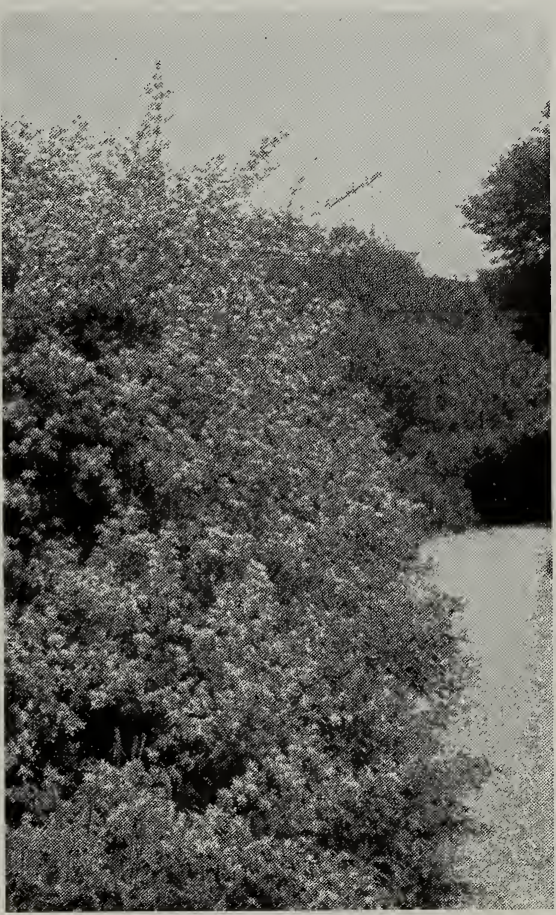

Busb Honeysuckle

Lonicera heckrottii

Low-bush Honeysuckle

Forms a spreading tangle of pretty gray branches, which make it good for covering banks; flowers cream and scarlet.

4 to $5 \mathrm{f}$

$\$ 0 \quad 50 \$ 4 \quad 50$

Manchurian Honeysuckle

Lonicera ruprechtiana

$\begin{array}{llll}\text { Tall rapid grower; pure white flowers; orange-red fruits. Each } & 10 \quad 100\end{array}$

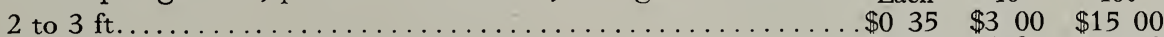

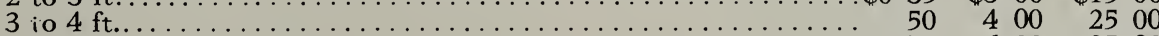

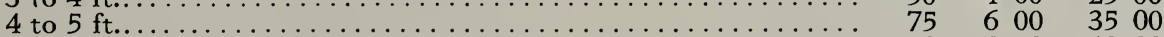

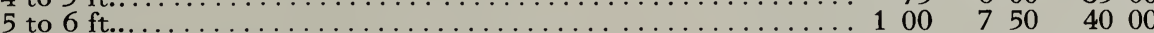

Standish's Honeysuckle

Lonicera standishii

A spreading shrub; half evergreen; slightly tender north of Long Island.

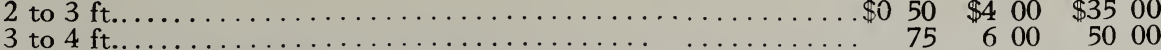

NO CHARGE FOR PACKING 
Tall strong-growing shrubs, as are all the following varieties. The type has crimson flowers.

2 to $3 \mathrm{ft}$...

\begin{tabular}{rrrr} 
Each & \multicolumn{1}{c}{10} & 100 \\
$\$ 0$ & 35 & $\$ 300$ & $\$ 1500$ \\
50 & 3 & 50 & 2000 \\
75 & 500 & 2500
\end{tabular}

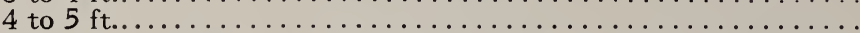
2500

White Tartarian Bush Honeysuckle. Lonicera tatarica, var. alba. Large pure white flowers.

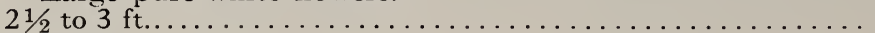

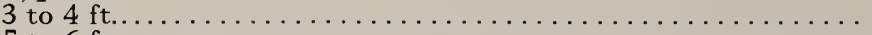

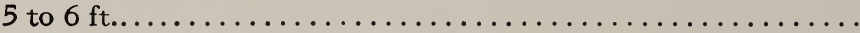

Bush Honeysuckle. L. tatarica, var. bella albida. Has particularly handsome white flowers.

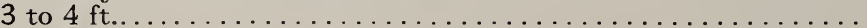

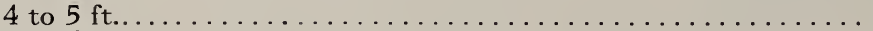

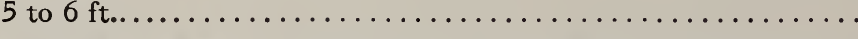

$\begin{array}{lllll}50 & 4 & 00 & 25 & 00\end{array}$

Bush Honeysuckle. L. tatarica, var. chrysantha. One of the neatest growing varieties, with handsome white flowers.

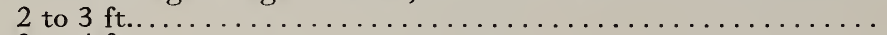

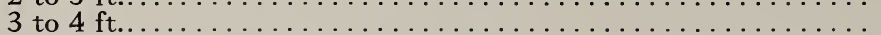

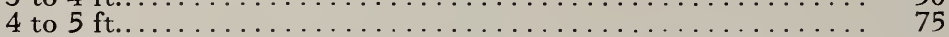

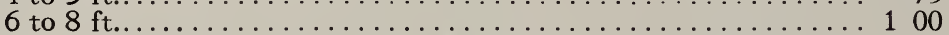

$500 \quad 3000$

Bush Honeysuckle. L. tatarica, var. gracilis. Of medium height with pretty white flowers. Berries orange red.

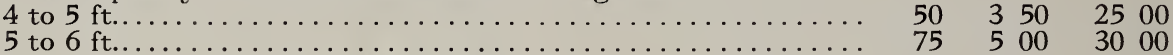

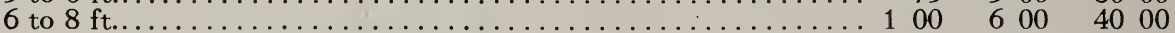

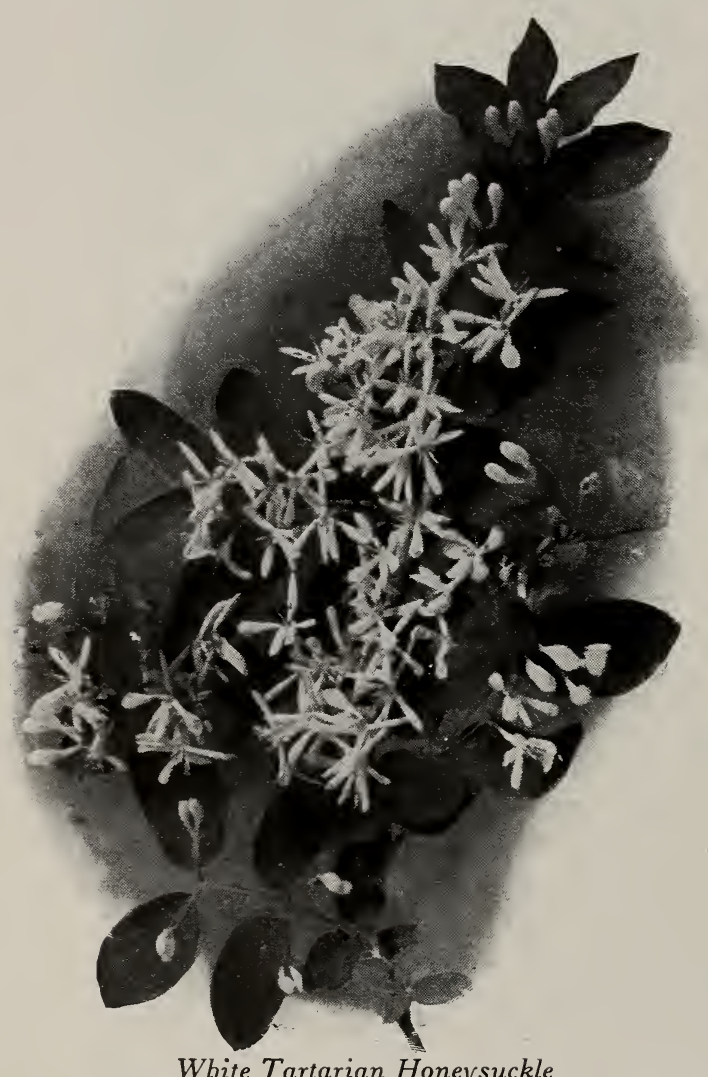

Wbite Tartarian Honeysuckle

Bush Honeysuckle. L. tatarica, var. splendens. Beautiful free-growing variety. Berries are deep red.

$\begin{array}{lrrr}\text { Each } & 10 & 100 \\ 2 \text { to } 3 \mathrm{ft} . \ldots \ldots \ldots \ldots & 35 & \$ 300 & \$ 1500 \\ 3 \text { to } 4 \mathrm{ft} . \ldots \ldots \ldots \ldots & 50 & 350 & 2000 \\ 4 \text { to } 5 \mathrm{ft} . \ldots \ldots \ldots \ldots & 75 & 500 & 2500 \\ 5 \text { to } 6 \mathrm{ft} . \ldots \ldots \ldots \ldots & 00 & 600 & 3000\end{array}$

Bush Honeysuckle, Mixed Sorts. L. tatarica.

4 to $5 \mathrm{ft} . \ldots \ldots \ldots \ldots 25 \quad 2500 \quad 1500$ 5 to $6 \mathrm{ft} . \ldots . \ldots 0035 \quad 3000$ 6 to $8 \mathrm{ft}$. Heavy.. $50 \quad 400 \quad 3000$

\section{Fly Bush Honeysuckle}

\section{Lonicera xylosteum}

A large shrub, with duII green leaves; flowers yellowish white, tinged with red. The late spring bloom is followed by dark red berries.

There is no family of shrubs more useful for the border or more satisfactory for medium-height summer screens than these flowering Honeysuckle bushes. In the spring they start to bloom and by midsummer they are covered with masses of yellow, orange, or red berries. They should be used entirely in mass effects, either in conjunction with other shrubs, or if planted by themselves the effect is most satisfactory.

4 to $5 \mathrm{ft} \ldots \ldots \ldots \ldots \ldots \ldots \$ 050 \quad \$ 400$ 


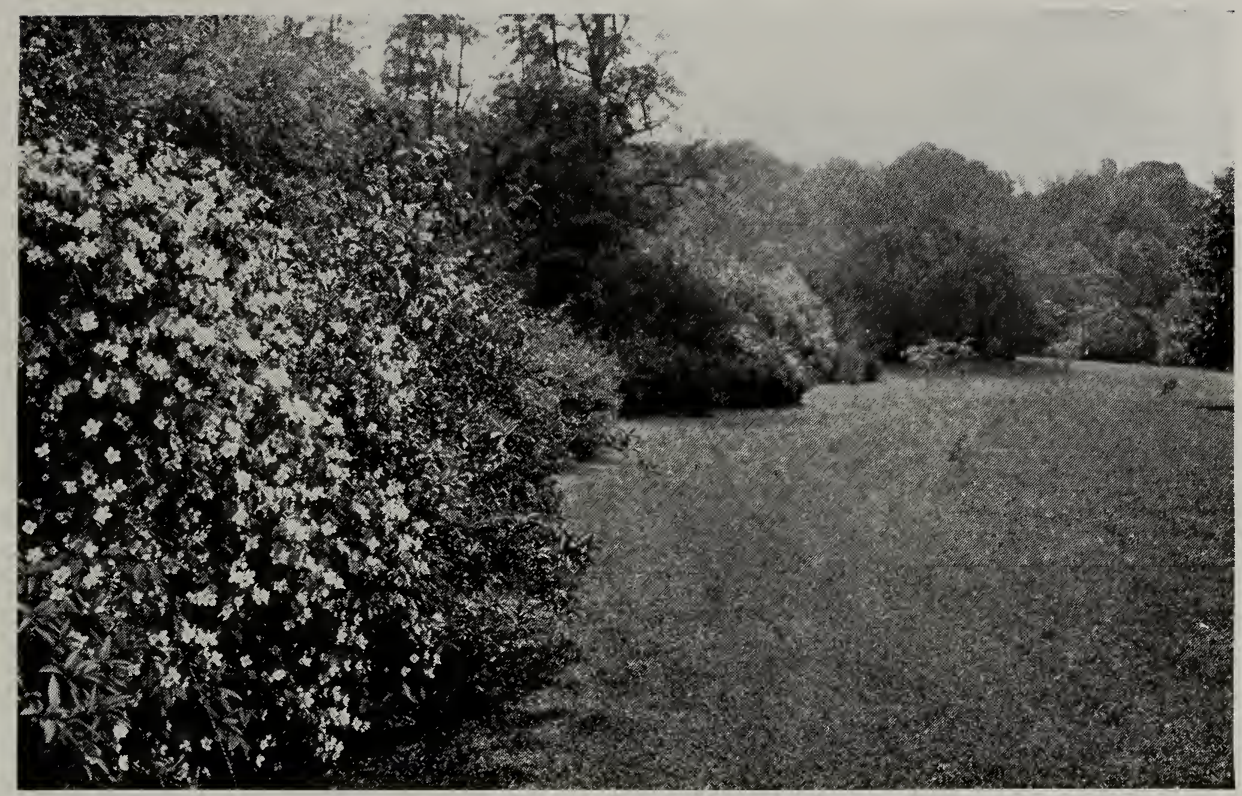

An effective border of shrubs about the lawn with a specimen Mock Orange in the foreground

\section{Mock Orange, or Syringa}

Philadelphus

OId-fashioned shrubs whose fragrant creamy white flowers, borne in profusion, are part of the charm of so many old places. The many varieties offer improvements over the old sorts in size of flower or habit of growth. AII are strong-growing, tall shrubs, suitable for border or screen or as specimens in garden or lawn.

Mock Orange. Philadelphus coronarius. Fragrant white flowers.

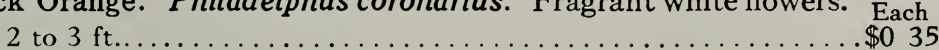

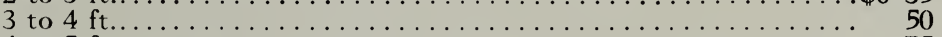

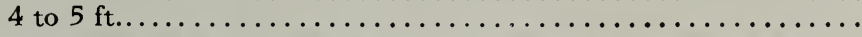

Golden-leaved Mock Orange. Philadelphus coronarius, var. aureus. Warm yellow foliage; white flowers.

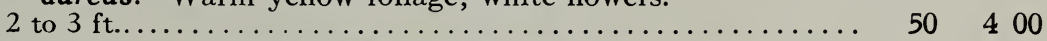

Mock Orange. Philadelphus grandiflorus. Very Iarge, showy, pure white flowers.

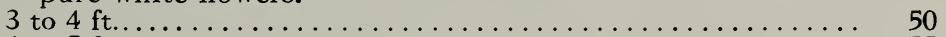

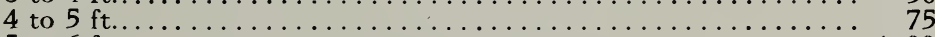

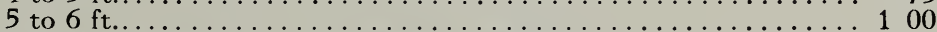

$10 \quad 100$

$\$ 300 \$ 1500$

4
6 $00 \quad 2000$

600

Hybrid Mock Orange. Philadelphus lemoinei. Graceful habit, very luxuriant foliage. A profusion of white, fragrant flowers in clusters cover this shrub in late spring.

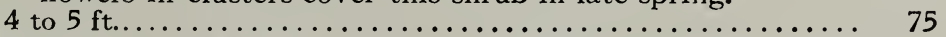

$400 \quad 2000$

$500 \quad 2500$

$750 \quad 3000$

P. lemoinei, var. erectus. Not so spreading in habit as the above; with fragrant white flowers in clusters. A prolific bloomer and carries fine foliage.

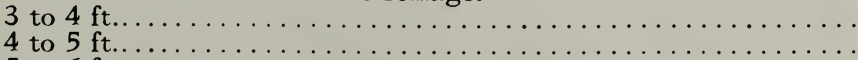

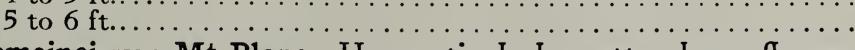

P. lemoinei, var. Mt. Blanc. Has particularly pretty, showy flowers.

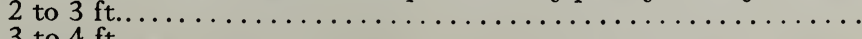

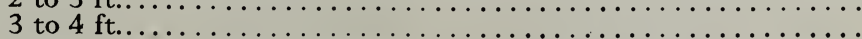

P. zeyheri, var. speciosissimus. Large, pure white, fragrant flowers, more than an inch across. The most showy of the Mock Oranges.

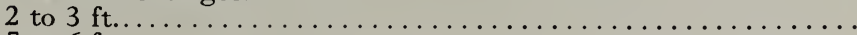

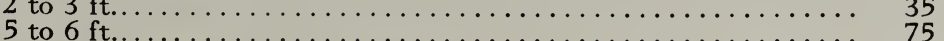

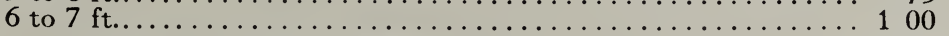




\section{Single Roses}

Rosa

The grace and charm of these beautiful shrubs appear to better effect in the informal border or shrubbery than in the rose-garden. In addition to their lovely

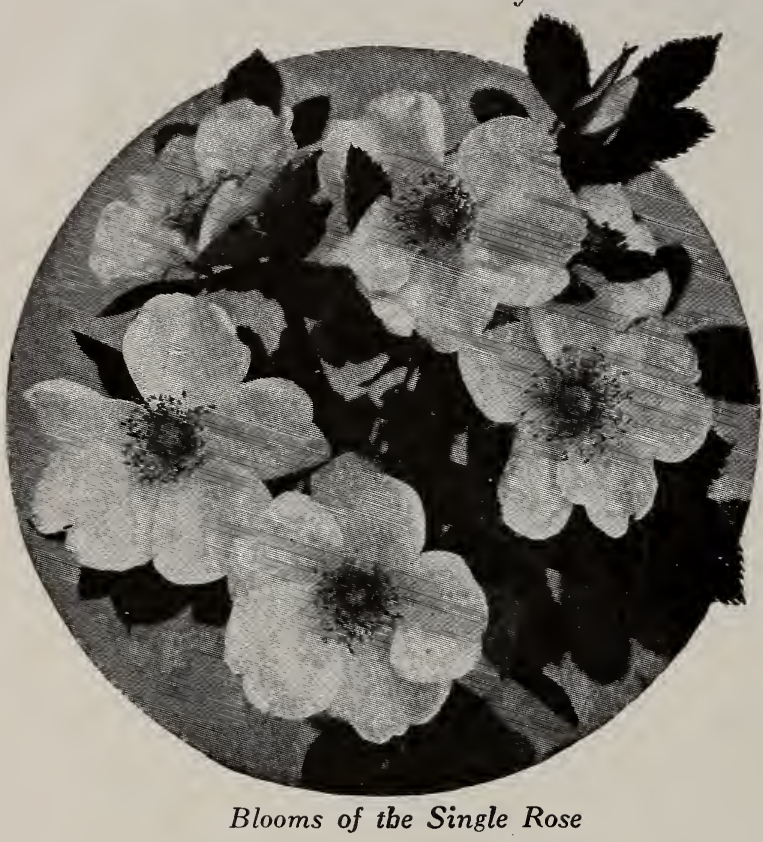

flowers, they possess the merit of fall and winter effects with red twigs and bright fruit. Other varieties blooming in midsummer will be found under that heading, while the garden Roses are catalogued as such.

Meadow Rose. Rosa blanda. Our wild pink Rose, with which the roadsides are painted in Iate May and early June, should be used in masses for the best effects. 35 cts. each, \$3 for 10.

Japanese Rose. Rosa multiflora. A profusion of white flowers covers the long, arching branches; half-climbing but fine in the shrubbery. June. 35 cts. each, $\$ 3$ for 10 .

Scotch Rose. Rosa spinosissima. Lowgrowing with very prickly brown branches. The bright green foliage is almost hidden when the Iarge sweet flowers of white or blush white open in their great clusters; the bud of this variety is most beautiful. The Scotch Rose is hardy in most situations, and for massing is unexcelled. $75 \mathrm{cts}$. each, $\$ 5$ for 10 .

Red-leaved Rose. Rosa rubrifolia. Very attractive, deep red-tinged leaves and branches; an upright shrub; flowers pink. June. 35 cts. each, \$3 for 10 .

White Kerria

Rhodotypos kerrioides

Japan has given us few shrubs of more merit. Its snow-white flowers are given in great profusion, and in May the plant is simply covered with flowers which are followed by jet-black seeds. Note should be made that this is a splendid shrub for semi-shady positions.

2 to $3 \mathrm{ft}$..

$\begin{array}{lll}\text { Each } & 10 & 100\end{array}$

3 to $4 \mathrm{ft}$...............

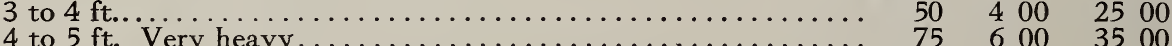

$\$ 035 \$ 300 \quad \$ 2000$

Golden Currant

Ribes aureum

Particularly valuable in the border for the fragrance of its yellow blossoms in spring. Its glossy green foliage colors well in the fall.

2 to $3 \mathrm{ft} . \ldots \ldots \$ 0 \quad$ Each $\quad 10$

\section{Pink-flowered Currant}

\section{Ribes gordonianum}

A large upright shrub with profuse crimson-colored flowers in late May.

2 to $3 \mathrm{ft} . \ldots \ldots \ldots \$ 0 \quad$ Each ${ }^{10}{ }^{10} \$ 30$

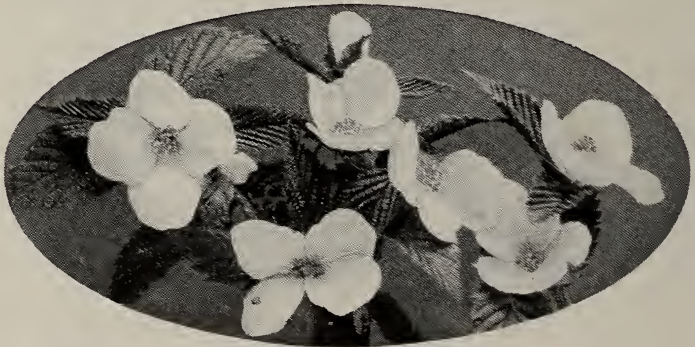

Flowers and foliage of White Kerria 


\section{Elderberries}

\section{Sambucus}

Vigorous, tall-growing shrubs, adapted to border or wild planting. Showy white flowers and attractive fruit, from which a very good wine is sometimes made. One of the very best shrubs for attracting song-birds; for which purpose it should be planted as a thicket.

\section{Black Elderberry}

Sambucus canadensis

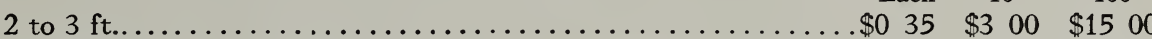

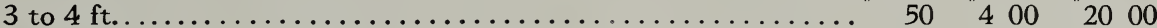

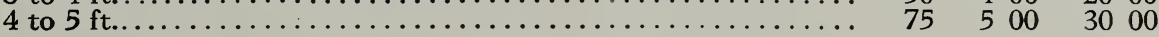

Great Elderberry

Sambucus melanocarpa

Very large heads of white flowers; dark green foliage; strong grower.

Each 10

$\$ 075 \$ 600$

Golden-leaved European Elderberry

Fruit black; variegated leaves.

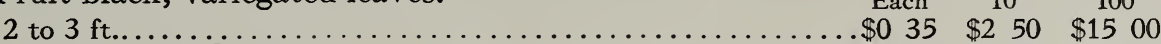

3 to $4 \mathrm{ft}$. Very heavy ................................... $50 \quad 350 \quad 2000$

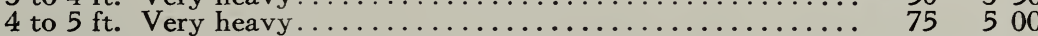

Cut-leaved European Elderberry

Sambucus nigra, var. laciniata Each $10 \quad 100$

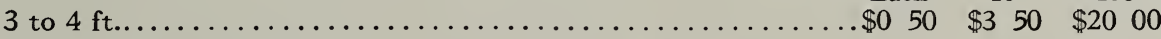

Red-fruited Elderberry

Sambucus pubens (racemosa)

Attractive red fruits appear in early summer.

2 to $3 \mathrm{ft}$

$\begin{array}{lll}\text { Each } & 10 & 100\end{array}$

.$\$ 035 \quad \$ 2 \quad 50 \quad \$ 1500$

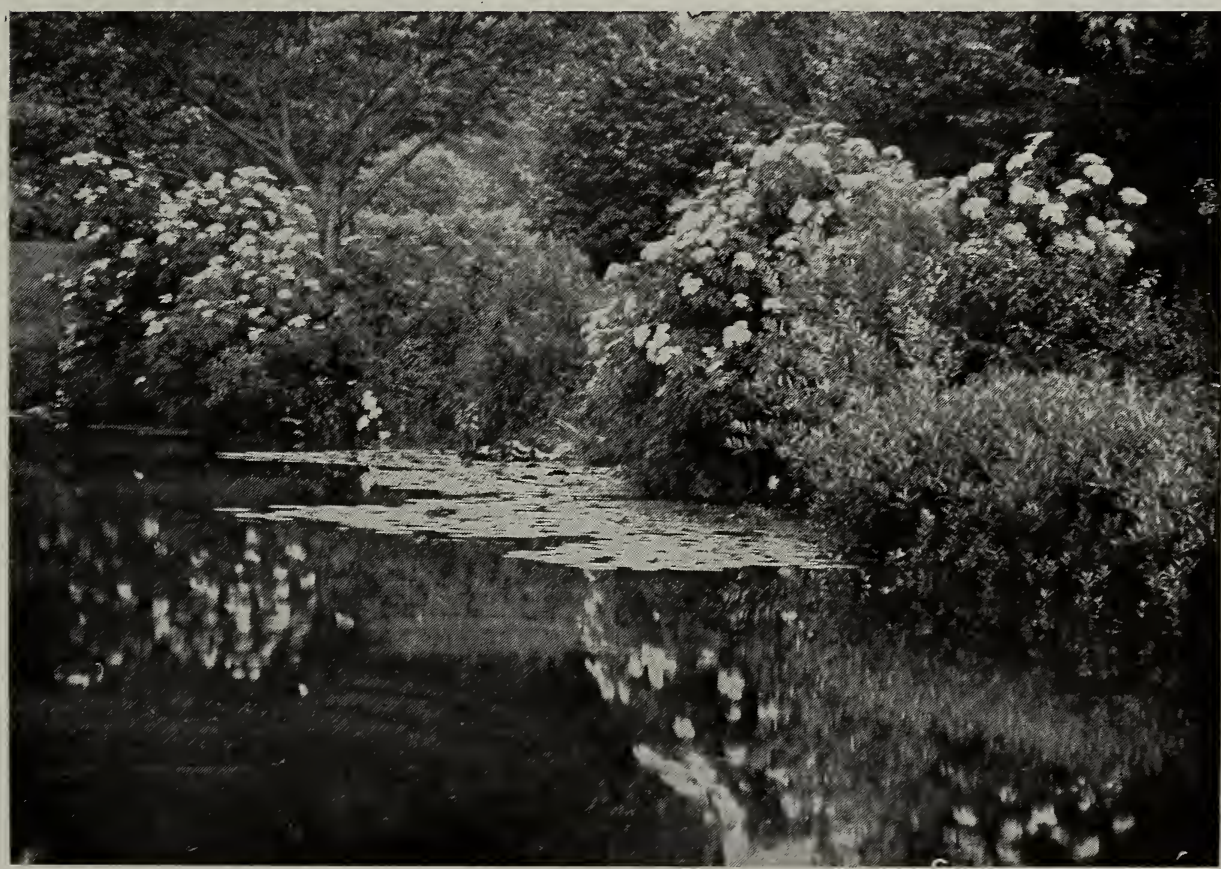

The delightful effect of the Black Elderberry when in blossom

NO CHARGE FOR PACKING 


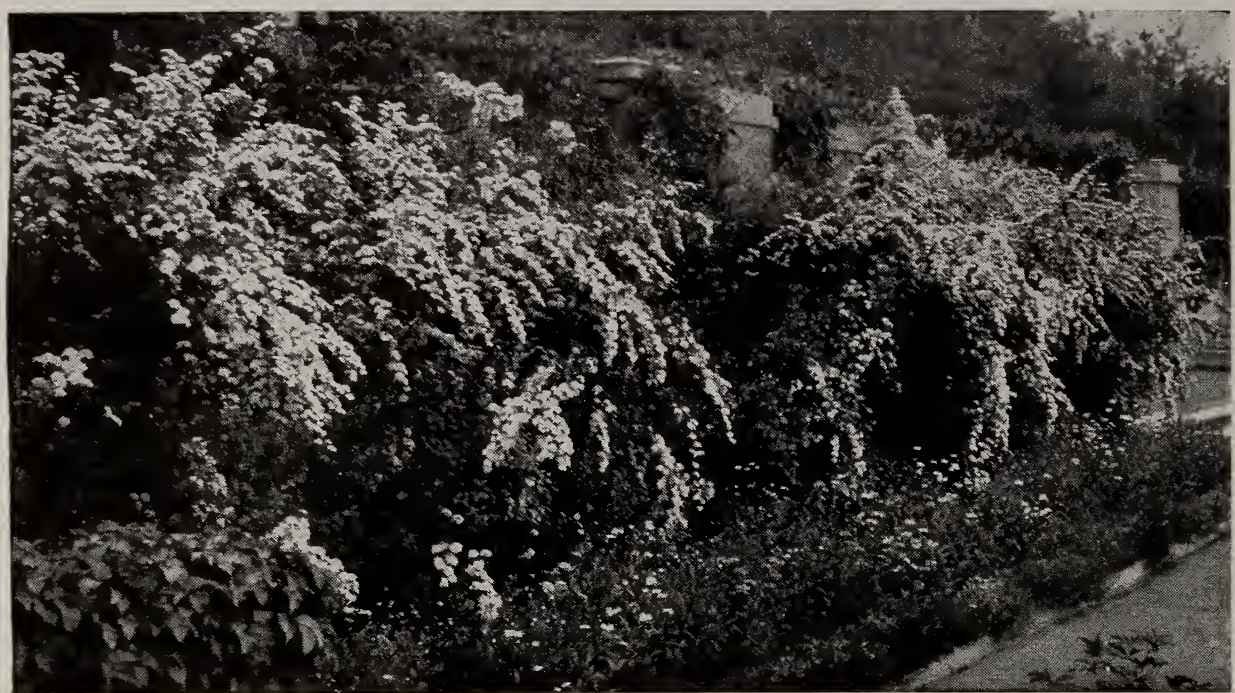

Spiræa Vanbouttei

\section{Spring-blooming Spireas}

Spiraea

The following varieties of Spirea are all very attractive shrubs for garden or shrub border, bearing a profusion of snowy white flowers in spring and early

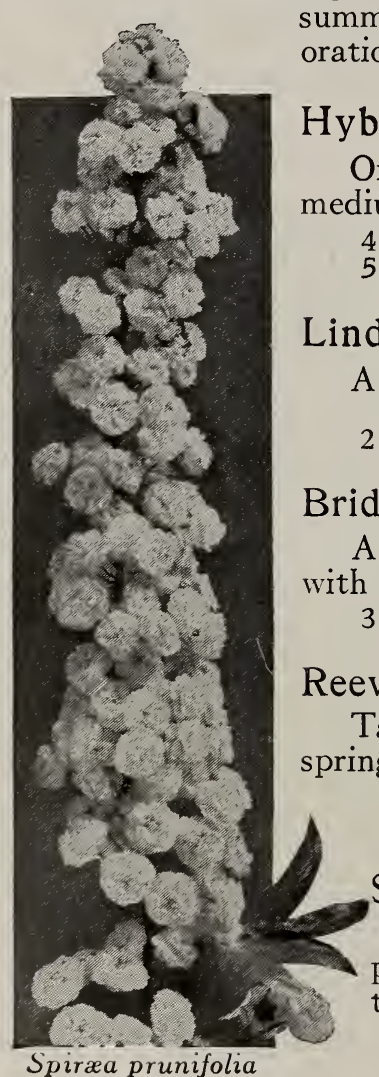

flore-pleno summer. The flowers are admirable for cutting for house decorations. SEE, ALSO, MIDSUMMER EFFECTS, PAGE 120

One of the earliest shrubs to blossom in the spring; of medium height.

Each 10

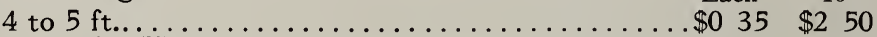

5 to $6 \mathrm{ft}$. Heavy......................... $50 \quad 400$

Lindley's Spirea

Spiræa lindleyana

A low-spreading shrub with pretty white flowers in spikes.

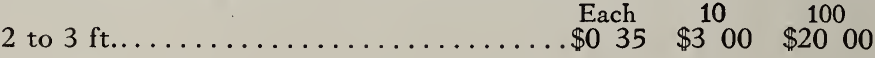

Bridal Wreath Spiræa prunifolia flore-pleno

A white-flowered, old-fashioned shrub; vigorous-growing with slender, arching branches. $\quad$ Each $10 \quad 100$

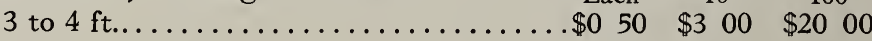

Reeves' Spirea

Spiræa reevesiana

Tall-growing; Iarge, double, pure white flowers in late spring. $\quad$ Each $10 \quad 100$

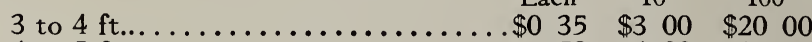

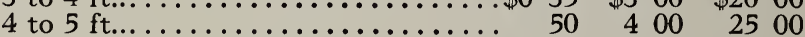

Snow Garland

Spiræa thunbergii

Low-growing; a smother of white in earliest spring; pretty, airy foliage, producing pleasing color effects in the fall border. $11 / 2$ to $2 \mathrm{ft} \ldots \ldots \ldots \ldots \ldots \ldots \ldots \ldots \ldots 035 \$ \$ 300 \quad \$ 2000$ 2 to $21 / 2 \mathrm{ft}$. Very heavy........... 50 3 $50 \quad 3000$ 3 to $3 \frac{1}{2} \mathrm{ft}$. Very heavy.......... $75 \quad 400 \quad 3500$ 
Bridal Bower

Spiræa vanhouttei

No other shrub can equal its profusion of white bloom on graceful arching branches in late spring; tall-growing; makes a beautiful informal flowering hedge.

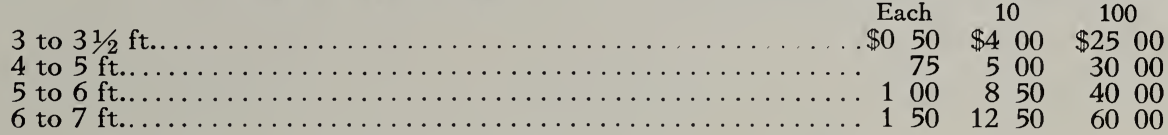

\section{Ninebark}

Spiræa opulifolia

Quick-growing and very tall, making it useful for screen plantings; both varieties are loaded with flowers in June.

3 to $4 \mathrm{ft}$.

\begin{tabular}{|c|c|c|}
\hline Each & 10 & 100 \\
\hline.$\$ 035$ & $\$ 250$ & $\$ 2000$ \\
\hline & $\begin{array}{ll}3 & 50 \\
4 & 00\end{array}$ & $\begin{array}{ll}25 & 00 \\
30 & 00\end{array}$ \\
\hline
\end{tabular}

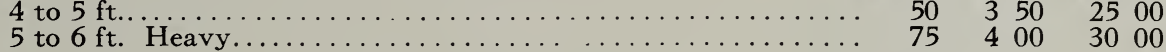

\section{Golden Ninebark}

Spiræa opulifolia, var. aurea

Same as the above, but with yellow foliage.

3 to $4 \mathrm{ft} . . . \ldots \ldots \ldots$

4 to $5 \mathrm{ft}$.

Each

$\$ 035$

$10 \quad 100$

$\begin{array}{rrrrr}35 & \$ 2 & 50 & \$ 20 & 00 \\ 50 & 3 & 50 & 25 & 00\end{array}$

5 to $6 \mathrm{ft}$. Heavy

$\begin{array}{lll}75 & 400\end{array}$

3000

\section{Lace Shrub}

\section{Stephanandra flexuosa}

Of value for its graceful, arching branches, white flowers and pretty fall coloring; medium height.

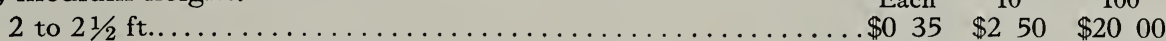

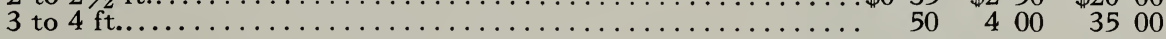

\section{Common Lilac}

Syringa vulgaris

This beautiful, old-fashioned shrub has been the origin of many Iarge-flowered varieties in rich shades of lavender and purple and white. $\begin{array}{lll}\text { Each } & 10 & 100\end{array}$

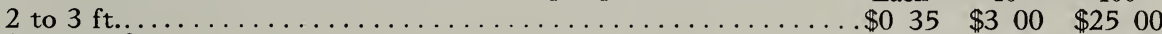

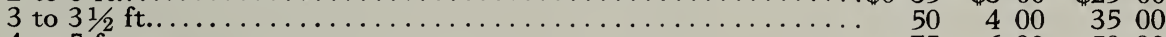

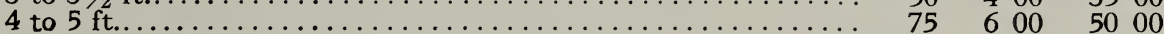

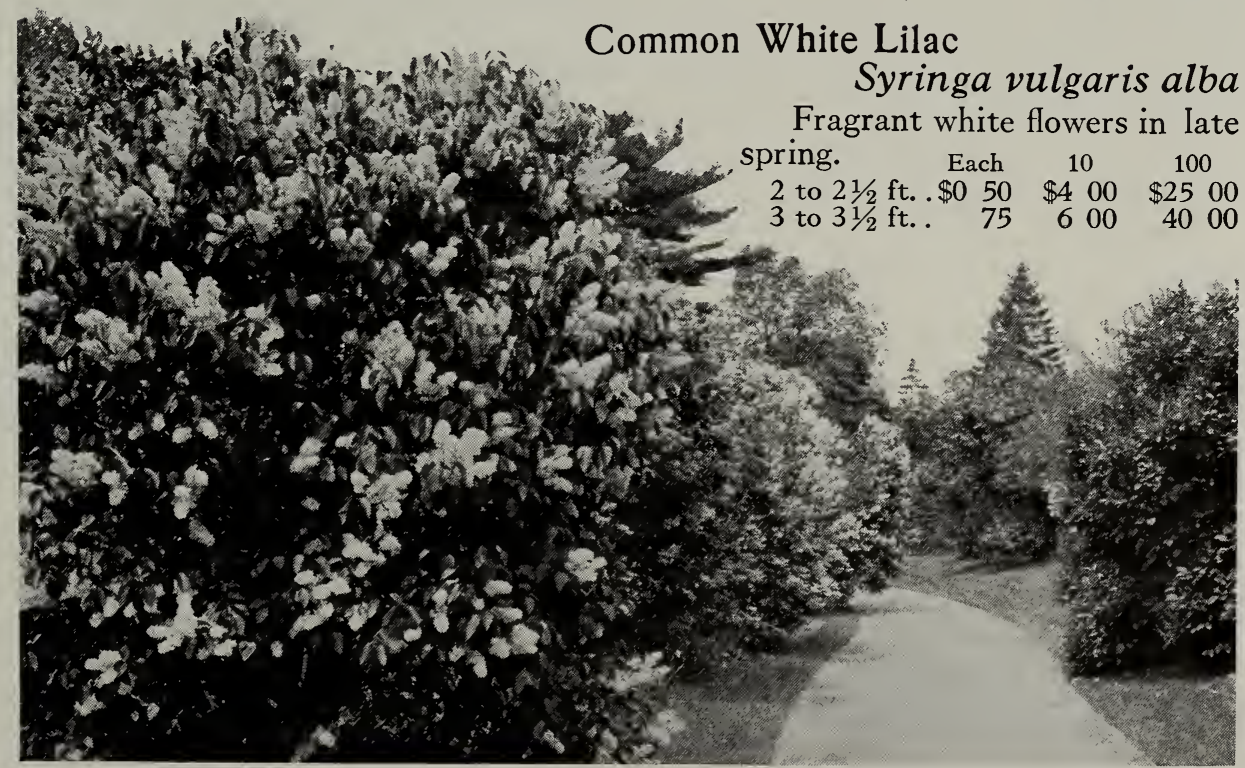

Lilacs massed at the Arnold Arboretum 


\section{Japanese Bladder-Nut}

Staphylea bumalda

From Japan; an upright shrub, bearing panicles of pretty white flowers which are followed by curious seed-pods.

Each 10

3 to $3 \frac{1}{2} \mathrm{ft}$

$\$ 0 \quad 50 \quad \$ 400$

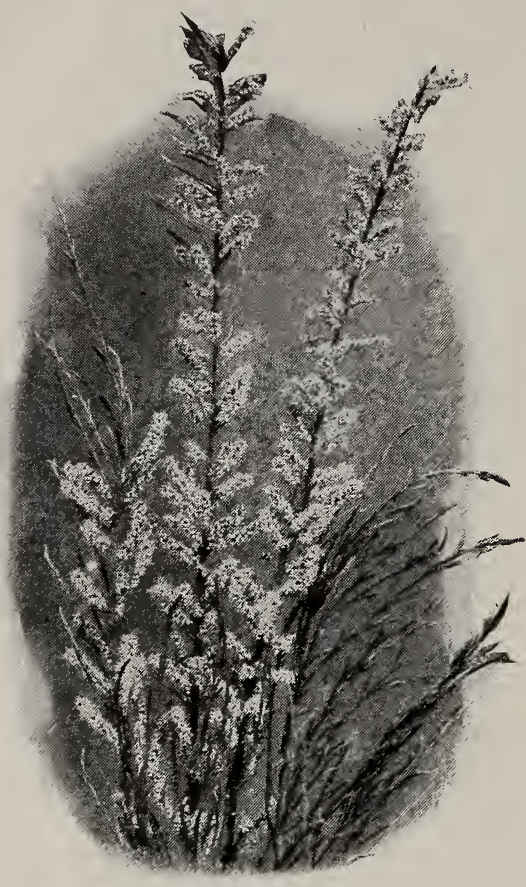

Tamarisk
Bladder-Nut

Tall-growing; fragrant white flowers in Iate spring, for the border.

2 to $3 \mathrm{ft}$

3 to 4

\section{African Tamarisk}

Tamarix africana (parviflora)

Tall-growing with feathery pink bloom. AII these varieties are well adapted for seaside planting, preferably in large masses. Other varieties are found under "Midsummer Effects in Deciduous Shrubs."

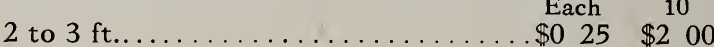

$$
\begin{aligned}
& 4 \text { to } 5 \mathrm{ft} . \ldots \ldots \ldots \ldots \ldots \ldots \ldots \ldots \ldots \ldots \ldots \ldots
\end{aligned}
$$

French Tamarisk

Tamarix gallica

Rosy white flowers from May till July.

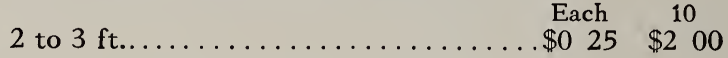

\section{Viburnum}

The Viburnums are all handsome, hardy shrubs and for an all-year-round effect in the shrubbery they are hard to equal. Their profuse clusters of creamy white spring blossoms are followed in Iate summer and fall by fruit-clusters, some black and some red, but all equally attractive; in addition, the handsome, dark green summer foliage, changing to rich autumn shades, and their pretty twigs in winter are pleasing in effect, especially when grouped in the border with the contrasting colors of the Osiers and Forsythias. They are fortunately free from insect pests.

\section{Dockmackie}

Viburnum acerifolium

Low-growing, fine for shady places; black fruit.

2 to $2 \frac{1}{2} \mathrm{ft} . . . \ldots$.

3 to $4 \mathrm{ft}$.

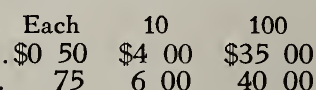

Viburnum carlesii

Sweet-scented Snowball

A new introduction of rare beauty and charm, bearing small clusters of delicate, pinkish white flowers of the most exquisite perfume; it will find a place in every garden. Of questionable hardiness as yet north of Long Island.

$1 \frac{1}{2}$ to $2 \mathrm{ft}$.

2 to $3 \mathrm{ft}$

Withe-Rod, or Wild Raisin

Each 10

$\$ 075 \$ \$ 60$

$\begin{array}{lll}100 & 900\end{array}$

\section{Viburnum cassinoides}

Of medium height; fruit red, changing to blue; as it grows naturally in swamps, it is well suited to waterside planting.

2 to $21 / 2 \mathrm{ft}$.

Each

$10 \quad 100$

3 to $31 / 2 \mathrm{ft}$. Very heavy

$\$ 050$

$\$ 450 \quad \$ 3500$

$31 / 2$ to $4 \mathrm{ft}$. Very heavy.

75

4 to $5 \mathrm{ft}$. Very heavy...

150 
Arrow-wood

Viburnum dentatum

Tall, upright-growing, with many branches from the ground; richly colored foliage in autumn, against which the black fruit shows to advantage.

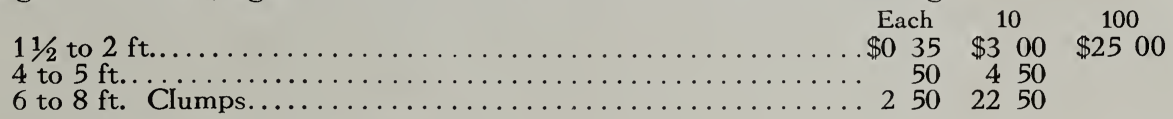

Japanese Bush Cranberry

Viburnum dilatatum

Tall-growing; handsome, persistent red fruits in autumn.

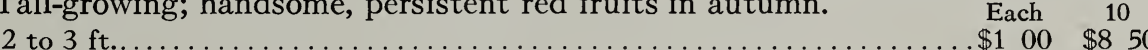

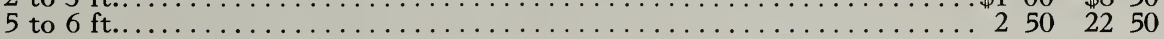

\section{Wayfaring Tree}

Viburnum lantana

Very tall-growing, Iarge shrub; berries bright red, changing to black; fine for screen-planting with low trees.

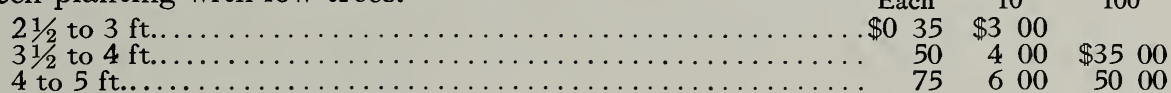

\section{Sheepberry}

Viburnum lentago

Attaining eventually the height of a small tree; glossy dark green leaves; large clusters of bluish black fruit.

2 to $3 \mathrm{ft}$

Each

10

100

3 to $4 \mathrm{ft}$

$\$ 050$

$\$ 400$

600

$\$ 3000$

4 to $5 \mathrm{ft}$

100

850

5000

\section{Silky Viburnum}

Viburnum molle

Tall, upright-growing shrub, with handsome small heart-shaped leaves; black fruit.

2 to $21 / 2$

3 to $31 / 2$

Each $10 \quad 100$

$31 / 2$ to 4

.$\$ 035$

60

$\$ 300 \quad \$ 2500$

$400 \quad 3500$

$\begin{array}{lllll}60 & 5 & 00 & 40 & 00\end{array}$

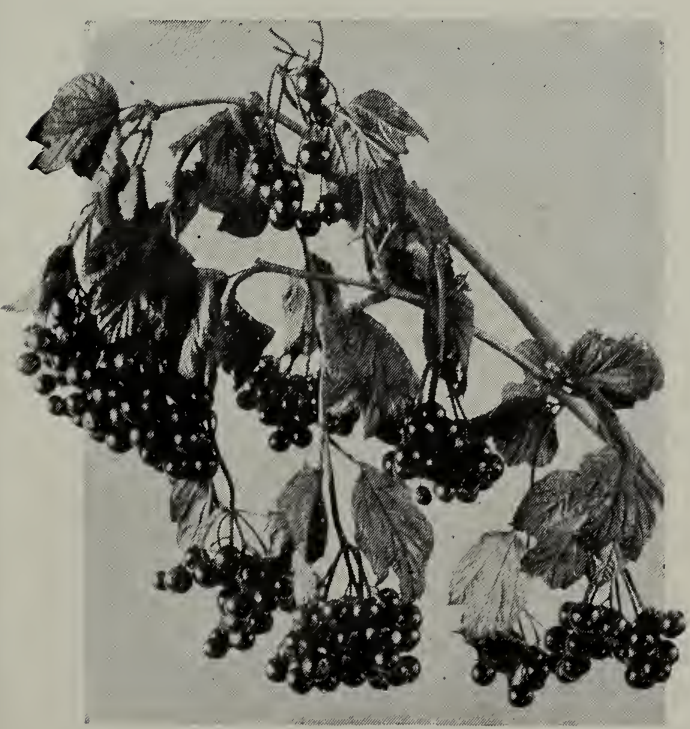

Berries of Viburnum opulus

\section{Viburnum nitidum}

A broad-spreading shrub, with shining, dark green leaves, handsome flowers and fruit bright rose-color, changing to blue.

Each

6 to $8 \mathrm{ft}$. Specimens ........\$500

\section{High-bush Cranberry}

\section{Viburnum opulus}

One of our best tall shrubbery plants, as the showy red fruit-clusters persist during the winter, and the light brown twigs are particularly pretty.

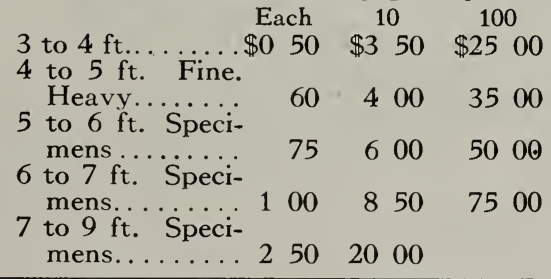

NO CHARGE FOR PACKING 


\section{Guelder Rose, or Snowball}

Viburnum opulus, var. sterile

A good, old-fashioned, tall shrub for a specimen or for planting in groups; showy flowers in large white "balls."

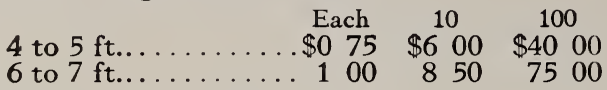

\section{Japanese Snowball}

Viburnum tomentosum, var. plicatum

Similar to the above, with Iarge flowerheads like snowballs and rich, handsome foliage; a beautiful, tall-growing shrub.

$$
\begin{aligned}
& 21 / 2 \text { to } 3 \mathrm{ft} \ldots \ldots \ldots \ldots \$ 0 \quad \begin{array}{ccc}
\text { Each } & 10 & 100 \\
40 & \$ 400 & \$ 3000
\end{array} \\
& 4 \text { to } 5 \mathrm{ft} . \ldots \ldots \ldots \ldots \ldots 100 \quad 7 \quad 50 \quad 5000
\end{aligned}
$$

\section{Single-flowered Japanese Snowball}

Viburnum tomentosum

A broad, tall-growing shrub, rich in the form and color of its branches, with showy cymes of white flowers, followed by brilliant red berries. For specimen or border, and most attractive for decorating.

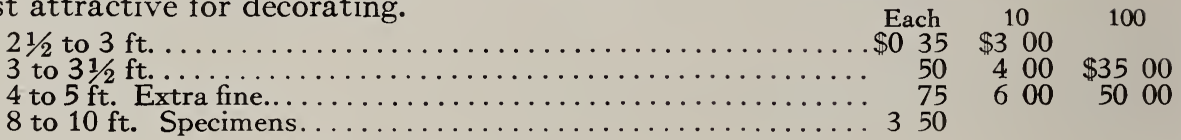

\section{Black Haw}

Viburnum prunifolium

Very tall shrub or small tree with handsome foliage, white flowers, and dark blue fruit.

Each 10

$2 \mathrm{ft}$.

$\$ 075 \$ \$ 00$

3 to $4 \mathrm{ft}$

100

850

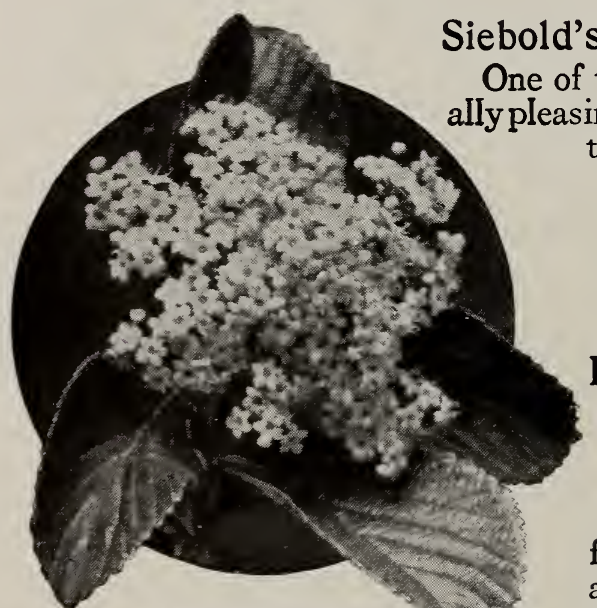

A typical cluster of flowers of Viburnum sieboldii.

Viburnum sieboldii

One of the handsomest introductions from Japan, especising in form and foliage; berries bright pink, changing to bluish black.

Each 10

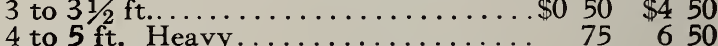

5 to 6 ft. Heavy............... $100 \quad 850$

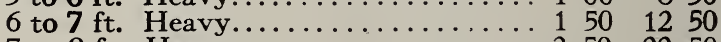

7 to $8 \mathrm{ft}$. Heavy................ 2502250

8 to $9 \mathrm{ft}$. Specimens.......\$3.50 to 500

High-bush Blueberry

Vaccinium corymbosum

A shrub of rare charm with dainty clusters of pinkish bell-like blossoms in early spring and very valuable for the rich fall colors of the foliage. Can be used in the border; especially attractive when associated with evergreens or for waterside planting. $\quad$ Each $10 \quad 100$ 1 to $11 / 2 \mathrm{ft}$. Clumps.........\$0 50 \$4 $50 \$ 4000$ $11 \frac{2}{2}$ to $2 \mathrm{ft}$. Clumps............ $75 \quad 700 \quad 6000$ 


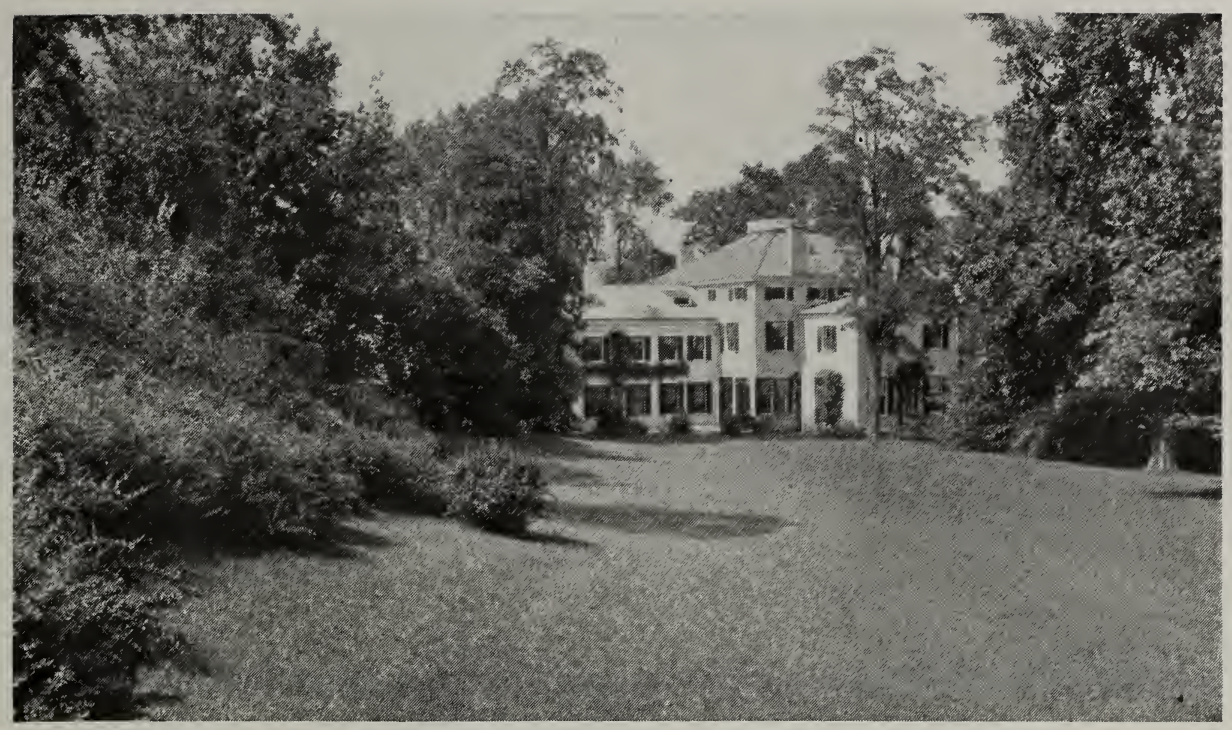

Border of Shrubs effectively inclosing the quiet lawn next the bouse

\section{Midsummer Effects in Deciduous Shrubs}

FTER the show of spring and early summer flowers is past, and we A settle down to the long, hot, drowsy days of midsummer, we are especially grateful for shrubs which brighten the borders or Iawns with flowers and seem to maintain the spirit of freshness of spring under the hot summer sun.

Many of the earlier spring-blooming sorts, like the Osiers, or Dogwoods, and Viburnums, are especially valuable in combination with these summerflowering shrubs for their excellent, clean foliage. Others, like the Bush Honeysuckles with their brilliant berries in Iate summer, already hold forth the promise of the gay colors which autumn has in store for us.

\section{Summer Lilac, or Butterfly Bush}

Buddleia veitchiana

A comparatively recent introduction, making a fine specimen, or equally attractive in groups in the border. Blooms continuously throughout the summer, the flowers resembling Lilacs in color and form. Not always hardy north of Philadelphia but comes up quickly even if frozen back. If given a light, well-drained soil, the growth ripens better and is less liable to winter injury. No shrub of recent introduction gives more results for the money than does the Buddleia and when planted in masses with taller shrubs for a background or when grouped through the shrubbery it fills a long-felt need with its midsummer blooms which hold well into September.

Each 10

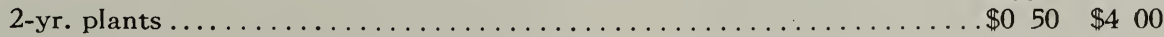

\section{Blue Spirea}

Caryopteris mastacanthus

One of the best of the new introductions from China, producing a profusion of rich blue flowers. If frozen back to the ground, it quickly recovers. WeIl suited for the garden or border. 
Jersey Tea

Ceanothus americanus

Low-spreading, hardy shrubs, valuable for dry, sandy situations; white flowers.

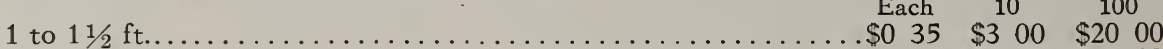

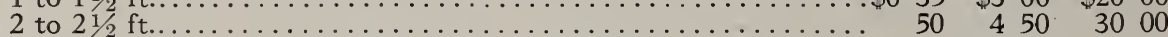

Hybrid Jersey Tea Ceanothus americanus, var. Gloire de Plantieres

Deep blue flowers in showy panicles; for the border or in masses.

$2 \mathrm{ft}$

Each

\$0 50

$10 \quad 100$

$\$ 300 \$ 2500$

Button Bush

Cephalanthus occidentalis

One of the best shrubs for waterside planting; fragrant white flowers; of medium height and rather open in habit.

4 to $5 \mathrm{ft}$....

5 to $6 \mathrm{ft}$

Each $10 \quad 100$

$\$ 0 \quad 35 \$ 300 \quad \$ 2500$

Sweet Pepperbush

Clethra alnifolia

Most valuable as a border plant on account of its profusion of fragrant white flowers in the hottest part of the summer; weIl adapted to moist situations.

2 to $3 \mathrm{ft}$.

Each 10

100

.$\$ 0 \quad 35 \$ 300 \quad \$ 2500$

\section{Althea, or Rose of Sharon}

Hibiscus syriacus

Hardy, tall-growing, symmetrical shrubs whose form and vari-colored blossoms make them most desirable for garden use or formal situations. They stand clipping very weIl and make handsome flowering hedges. The following varieties offer a wide range of colors and are improvements on the old-fashioned varieties in which the colors were rather crude.

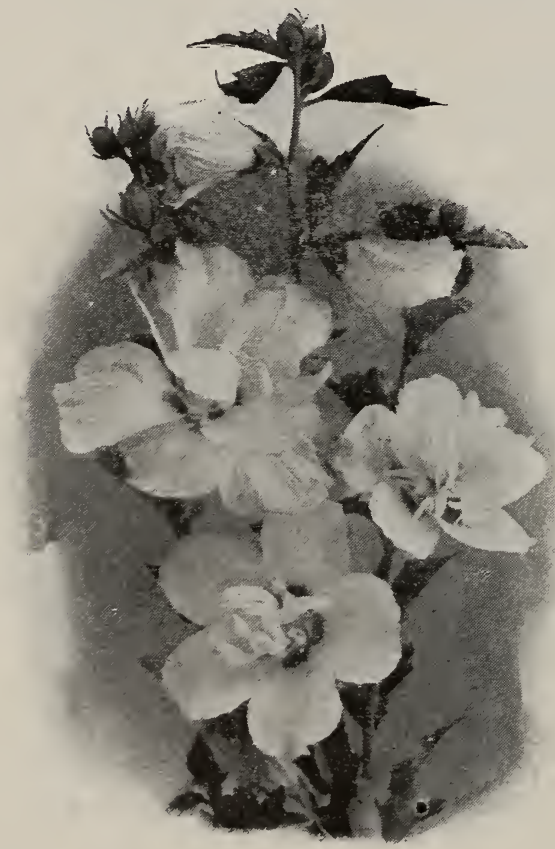

Hibiscus syriacus
$\mathrm{Hibiscus}$ atropurpureus Each $\quad 10 \quad 100$ plenus. Double, reddish purple.

5 to $7 \mathrm{ft} . . \ldots \ldots \ldots \ldots . \ldots 075 \$ 650 \$ 5000$

H., Boule de Feu. Double, red.

$31 / 2$ to $4 \mathrm{ft} . . \ldots \ldots \ldots \ldots 100 \quad 800$

H., Jeanne d'Arc. Double, pure white.

2 to $3 \mathrm{ft} . \ldots \ldots \ldots \ldots \ldots .50 \quad 400 \quad 2000$

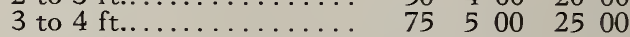

4 to $5 \mathrm{ft} . \ldots \ldots \ldots \ldots \ldots \ldots 100600$

H., Lady Stanley. Double, blush-white.

3 to $4 \mathrm{ft} . \ldots \ldots \ldots \ldots \ldots \ldots .50 \quad 400 \quad 2500$

4 to $5 \mathrm{ft} \ldots \ldots \ldots \ldots \ldots \ldots \ldots, 75 \quad 500 \quad 4000$

5 to $7 \mathrm{ft} . \ldots \ldots \ldots \ldots \ldots \ldots \ldots \ldots \ldots$

H. purpureus foliis argenteus marginatus. Double, purple, leaves margined with silver.

3 to $4 \mathrm{ft} . \ldots \ldots \ldots \ldots \ldots . \quad 50 \quad 400 \quad 2500$

H. totus albus. Single, pure white.

2 to $3 \mathrm{ft} \ldots \ldots 50 \quad 300 \quad 2000$

H. violaceus. Semi-double, deep violet.

6 to $8 \mathrm{ft}$.............. $100 \quad 8 \quad 850 \quad 7500$ 


\section{Tree-shaped Rose of Sharon}

We offer the following varieties grafted and trained as small, symmetrical, flowering trees with trunks about 2 to 3 feet high. They are especially valuable in formal gardens or for specimens, having the effect, with their profuse blooms in August, of handsome, great, tree roses.

Hibiscus, Ardens. Double, bluish purple. Each

5 to $6 \mathrm{ft}$. Standards............... \$1 $00 \quad \$ 8 \quad 50$

H., Boule de Feu. Double, red.

$31 / 2$ to $4 \mathrm{ft}$. Standards............ $100 \quad 850$

H., Jeanne d'Arc. Double, pure white.

5 to $6 \mathrm{ft}$. Standards............... $100 \quad 850$

H. purpureus foliis argenteus marginatus. Double, purple, leaves margined with silver.

5 to $6 \mathrm{ft}$. Standards............... 100

H. totus albus. Single, pure white.

3 to $4 \mathrm{ft}$. Standards................ $75 \quad 600$

\section{Hardy Hydrangeas}

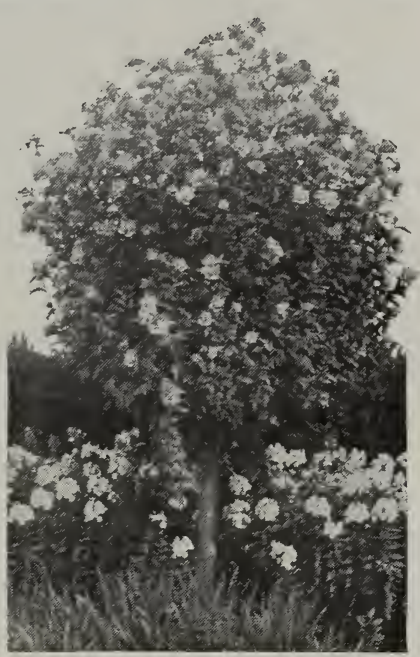

Among the best-known flowering shrubs, and valuable for their wealth of bloom in late summer and early fall. Used to good advantage in the border, in front of taller shrubs, or in groups by themselves.

Wood Hydrangea

Hydrangea arborescens

Especially valuable for shady places; fine foliage; clusters of tiny white flowers.

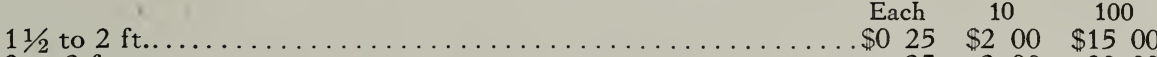

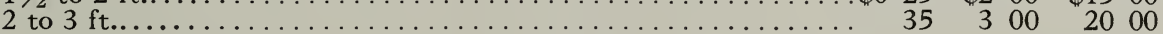

\section{Banks of Snow}

Hydrangea arborescens var. grandiflora

Has all the appearance of a Iow-growing Snowball, with its Iarge clusters of white flowers.

2 to $3 \mathrm{ft}$

\begin{tabular}{|c|c|}
\hline Each & 10 \\
\hline $\begin{array}{ll}\$ 0 & 25 \\
35\end{array}$ & $\begin{array}{rl}\$ 2 & 00 \\
3 & 00\end{array}$ \\
\hline
\end{tabular}

\section{Panicled Hydrangea}

Hydrangea paniculata

A tall shrub from Japan; most ornamental when massed in the border; loose,

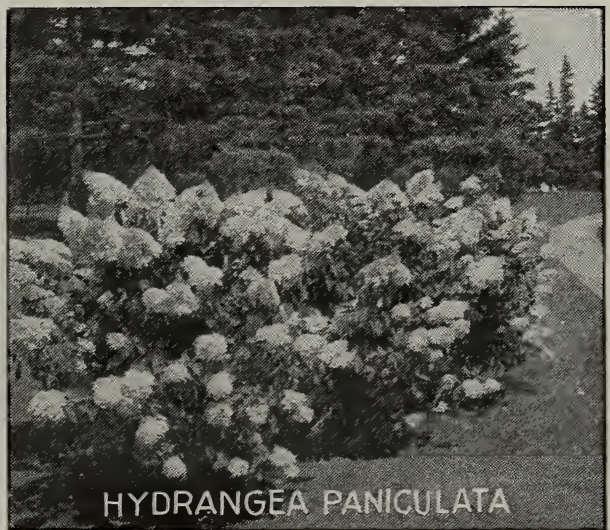
flat panicles of white flowers.

$\begin{array}{rrrrr} & \text { Each } & 10 & 100 \\ 3 \text { to } 4 \mathrm{ft} . \ldots \ldots . \$ 0 & 35 & \$ 300 & \$ 2000 \\ 4 \text { to } 5 \mathrm{ft} . \ldots \ldots & 50 & 400 & 3500 \\ 5 \text { to } 6 \mathrm{ft} . \ldots \ldots & 1 & 00 & 8 & 50\end{array}$

Lawn Hydrangea

\section{Hydrangea paniculata grandiflora}

One of the showiest shrubs in cultivation; flowers in huge white clusters, changing to rose and bronze; for specimens or border. Each $10 \quad 100$

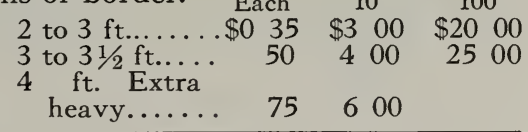

NO CHARGE FOR PACKING 


\section{St. John's-Wort}

Hypericum

Free-flowering low shrubs, blossoming through the summer, for garden or border use or in the rock-garden.

\section{Large-flowered St. John's-Wort}

Flowers golden yellow, several inches across.

Hypericum aureum

2 to $3 \mathrm{ft}$..

Each 100

4 to $5 \mathrm{ft}$

Goat-Wort

Deep yellow flowers; grows best in dry soils.

2 to $2 \frac{1}{2} \mathrm{ft}$.

Hypericum hircinum

Each $\quad 10 \quad 100$

\$0 $50 \quad \$ 350 \quad \$ 2500$

\section{Gold Flower}

Hypericum moserianum

Tremendously effective in groups or masses; Iarge, handsome golden yellow flowers.

Each $\quad 10 \quad 100$

10 to 15 in.................................\$0 $35 \quad \$ 2 \quad 50 \$ 2000$

\section{Shrubby St. John's-Wort}

Hypericum prolificum

Low-growing; light yellow flowers; one of the best.

Shrubby Cinquefoil

Each $\quad 10 \quad 100$

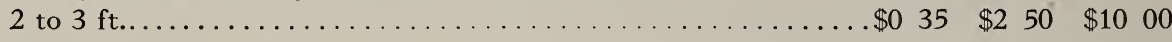

Bright yellow flowers through the summer make this a valuable border plant; medium height.

2 to $2 \frac{1}{2}$

Each

$10 \quad 100$

.$\$ 0 \quad 35 \$ 200 \quad \$ 1500$

\section{Single Bush Roses}

Rosa

In addition to the varieties blooming earlier in the season, which are adapted for border uses (see "Spring Flowers in the Shrubbery," and "Garden Roses"), we are fortunate in having the following varieties, which put forth their pretty single flowers during the hot summer months and by their bushy habit of growth are especially adapted to use in the shrubberies or borders. They are particularly effective in masses, on slopes, along the drive, or on steep banks. The red twigs of many varieties add charm to the winter landscape.

Price of Single Bush Roses, 35 cts. each, $\$ 3$ for 10

Dog Rose. Rosa canina. Upright shrub with curving branches; pink flowers in early summer, followed by showy scarlet hips.

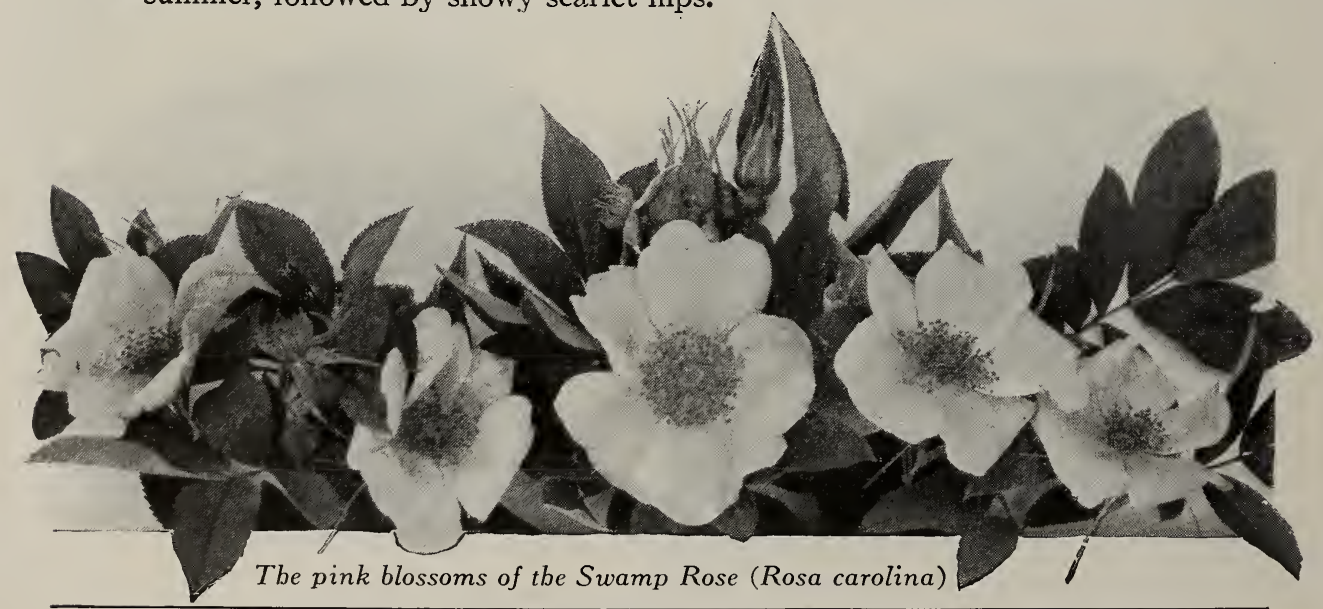

ANDORRA NURSERIES 


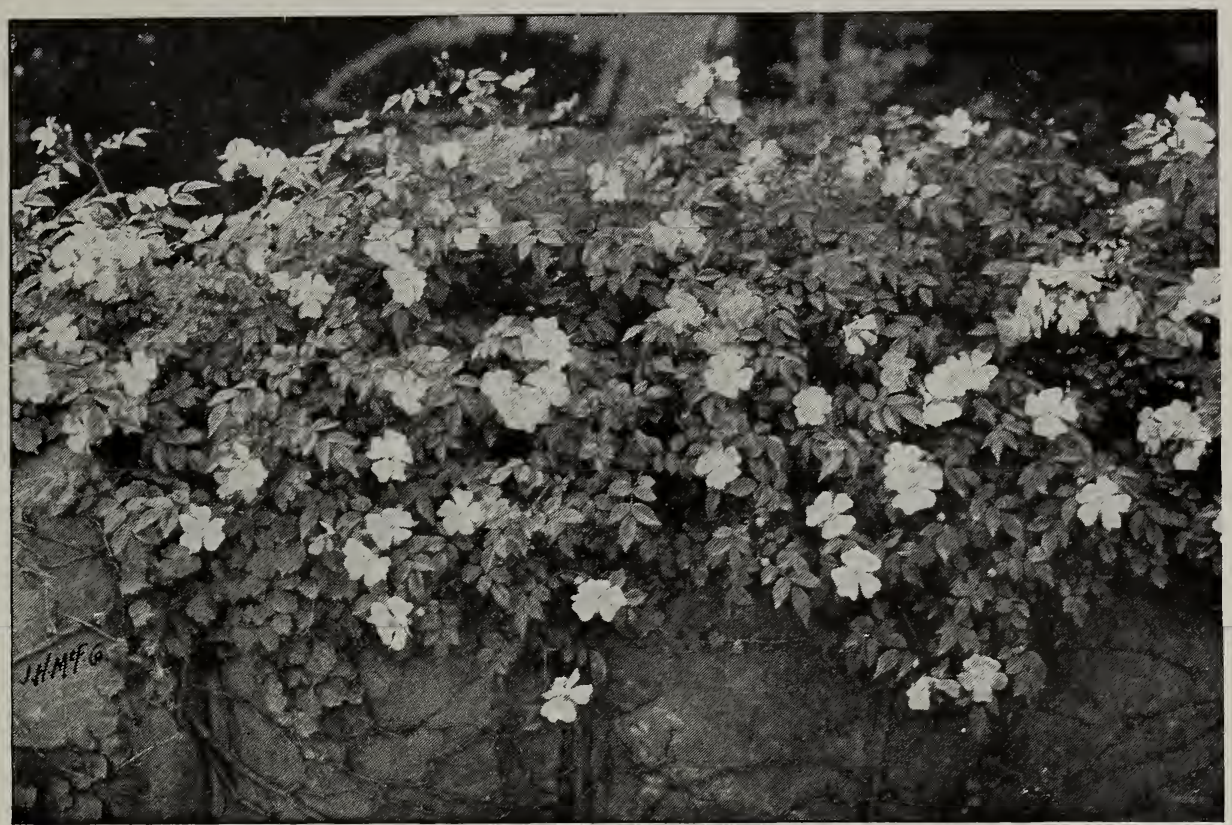

Memorial Rose

SINGLE BUSH ROSES, continued

Swamp Rose. $R$. carolina. Upright bush of medium height; pink flowers throughout the summer; red twigs. June to September.

Wild Rose. Rosa lucida. Low-growing; bright red twigs; pink flowers. June and July. White Wild Rose. R. lucida, var. alba. White flowers and green twigs; low-growing. June and July.

Shining-leaved Rose. $R$. nitida. Red flowers; a dwarf grower. June and July.

\section{Prairie Rose}

Rosa setigera

A graceful bush with red branches bending to the ground, and covered aII summer with single pink flowers of great beauty; attractive red fruits in faII and winter; bright red branches.

Each , 10

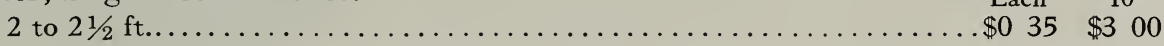

\section{Memorial Rose}

Rosa wichuraiana

Nothing can be more effective on slopes or banks than this spreading rose, with beautiful, pure white, fragrant flowers; may also be trained on fences and trellises.

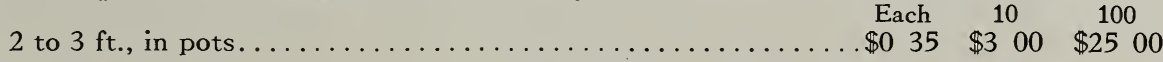

Japanese Rose

Rosa rugosa

Upright bush with gray branches, densely covered with spines; rich rosecolored and white flowers in distinct varieties, followed by large showy hips; good foliage. One of the best shrubs for seashore planting.

2 to $21 / 2 \mathrm{ft}$..

Each 10

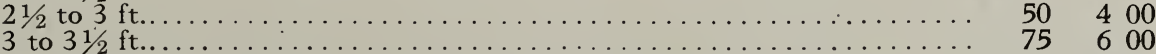

$\$ 035 \$ 300$

R. rugosa varieties. There are many wonderfully beautiful varieties of this fine Rose, which will be found under "Garden Roses."

Mist or Smoke Tree

Rhus cotinus

Open-growing, tall shrub or small tree covered in summer with the feathery, plume-like flowers which give it the common name.

3 to $4 \mathrm{ft}$.
4 to $5 \mathrm{ft}$.

Each 10

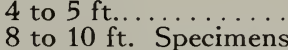

$\$ 050$

$\$ 400$

350

600

NO CHARGE FOR PACKING 
Purple Mist Tree

Rhus cotinus, var. atropurpurea

Has a pretty purplish tinge to its feathery blossoms.

3 to $4 \mathrm{ft} . . . . .$.

Each 10

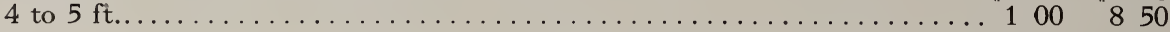

Rose Acacia

Robinia hispida

Soft rose-colored flowers, resembling in form the Wisteria, make this a most desirable shrub for garden or border.

Each 10

2 to $2 \frac{1}{2} \mathrm{ft}$.

$\$ 035 \$ 2 \quad 50$

\section{Large-flowered Pink Raspberry}

Rubus odoratus

Grows successfully in shade or open sunlight. Pretty rose-shaped flowers for several weeks in summer; for border or wild planting.

2 to $3 \mathrm{ft}$..

$\begin{array}{lll}\text { Each } & 10 & 100\end{array}$ .$\$ 035 \quad \$ 2 \quad 50 \quad \$ 1500$

\section{Summer-blooming Spireas}

Spiraea

These low-growing plants are among the best for midsummer effects and are hardy, vigorous growers.

SEE, ALSO, SPRING FLOWERS, PAGE 109.

Spiræa billardii. Bright pink flowers in dense panicles; fine for cutting; a medium height shrub for massing in the border.

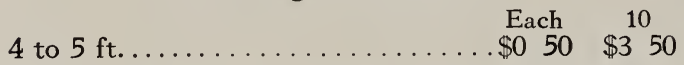

Everblooming Spirea. Spiræa bumalda. Very low shrub with deep pink flowers blooming throughout the summer, for the low border.

2 to $3 \mathrm{ft}$. Each $\$ 050 \$ 350$

Everblooming Crimson Spirea. Spiræa bumalda, var. Anthony Waterer. Its bright blooms make a pretty spot of color in the low shrubbery all summer long. Each $10 \quad 100$ 15 to 18 in............. \$0 $35 \$ 2 \quad 50$

18 to 24 in. Heavy........ $50 \quad 400 \quad \$ 2500$

2 to $21 / 2 \mathrm{ft}$. Heavy.......... $75 \quad 500 \quad 3000$

$3 \mathrm{ft} . \ldots \ldots \ldots \ldots \ldots \ldots, 100 \quad 750$

Fortune's Spirea. Spiræa callosa. A small shrub, covered with pretty pink blossoms.

3 to $4 \mathrm{ft}$......

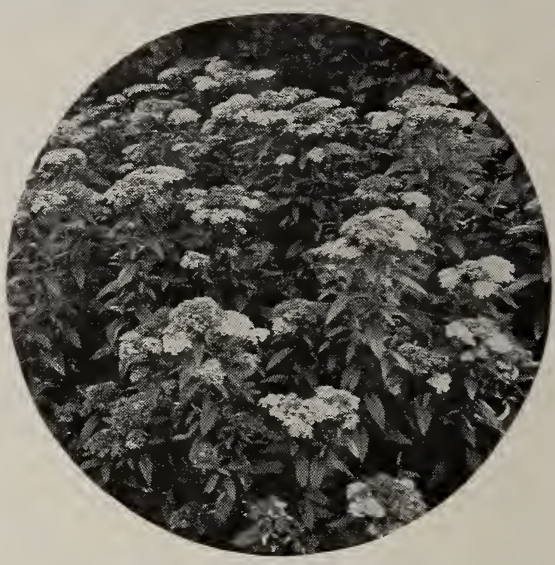

Spiræa, Antbony Waterer

Fortune's White Spirea. Spiræa callosa, var. alba. White flowers; a small shrub like the above.

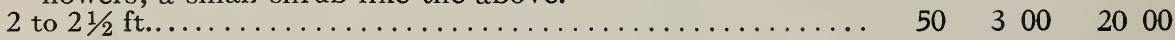

Pink Hybrid Spirea. Spiræa callosa margaritæ. Low-growing, spreading shrub with pretty, flat-topped heads of pink flowers.

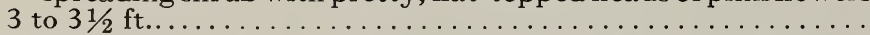

S. salicifolia. Upright shrub with many heads of pink-tinted flowers; for the border.

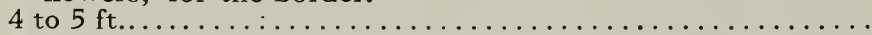

S. sorbifolia. One of the handsomest and showiest of shrubs for the border; white flowers in long spikes; graceful foliage.

3 to $4 \mathrm{ft}$......

50400

$35 \quad 250 \quad 2000$

\section{Storax}

Styrax japonica

Tall, spreading shrubs suitable for specimens or border; white nodding flowers.

3 to $4 \mathrm{ft}$

$\begin{array}{ll}\text { Each } & 10 \\ \$ 0 \quad 50 & \$ 400\end{array}$

4 to $5 \mathrm{ft}$.

$\$ 400$

6 to $8 \mathrm{ft}$.

100750 


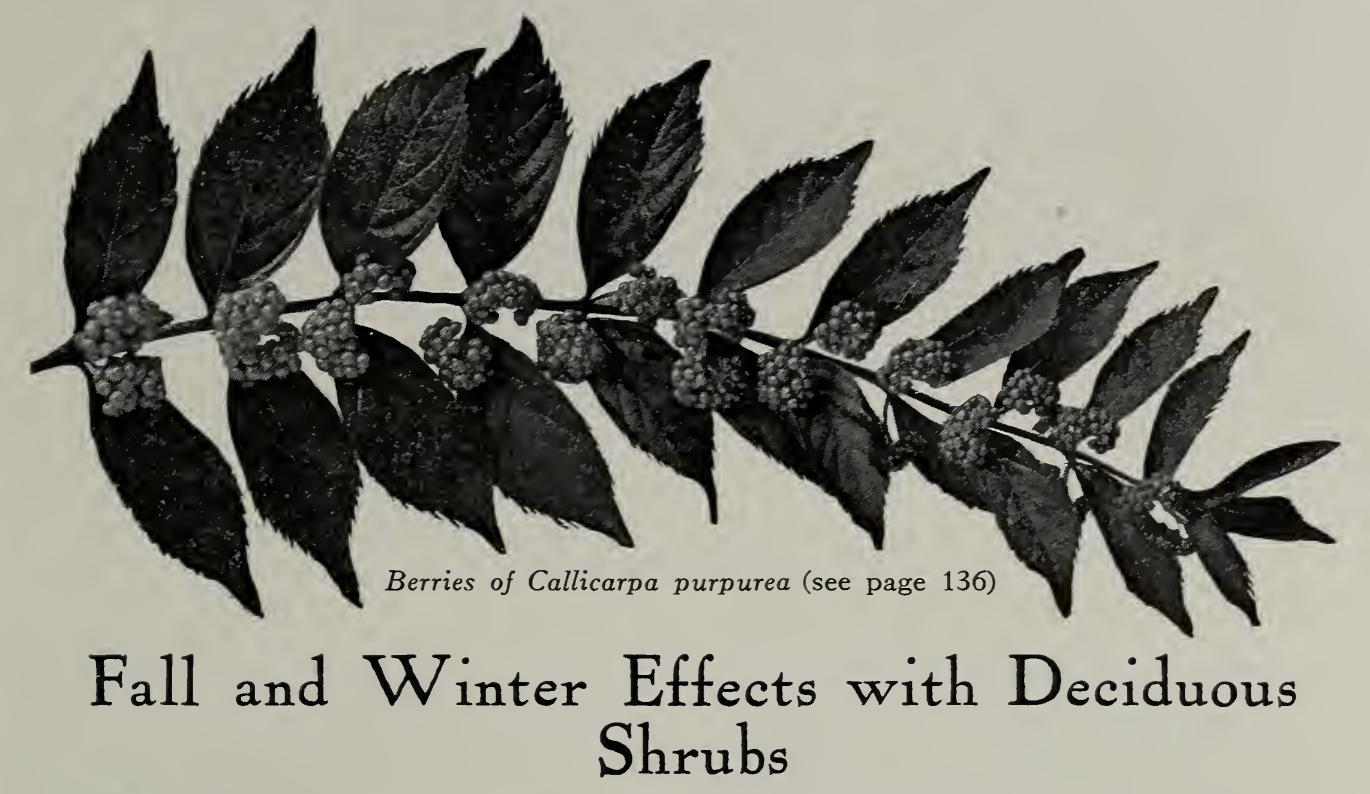

7 HE varieties in the following pages are especially attractive for the brilliancy of their fall coloring of berries or leaves or both. To this list must, of course, be added countless others equally attractive in Ieaf and fruit, but which have been listed under spring or summer bloomers. Among the shrubs of this sort which furnish equally attractive effects at different seasons are the Osiers (Cornus), the many varieties of $\mathrm{V}$ burnums, the Barberries and Ligustrums (Privets), the Honeysuckles and the Forsythias, with their graceful, warm brown winter branches.

Spice Bush

Benzoin odoriferum

Admirable for border, screen, or woods planting. Strong-growing shrub, bearing pretty dark red berries; good summer foliage and the brown twigs are most attractive in winter.

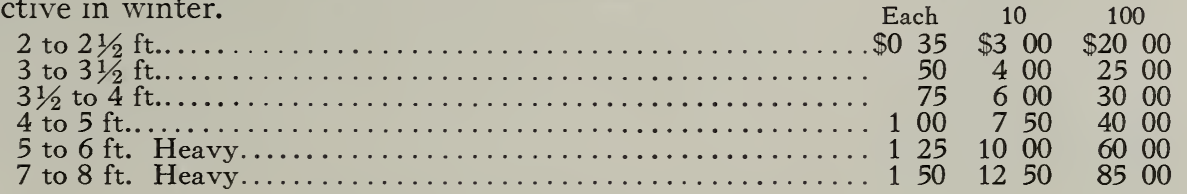

Siebold's Barberry

Berberis sieboldii

Large, spreading shrub, like the Common Barberry, but with larger, handsome fruit; good for the border.

4 to $5 \mathrm{ft}$. Heavy.

Each 10

$\$ 250 \$ 2350$

\section{Japanese Barberry}

Berberis thunbergii

Low, compact-growing shrub, adaptable to border or hedge planting, or clipped into forms suitable for formal work. These plants are very bushy and widespreading in proportion to their height.

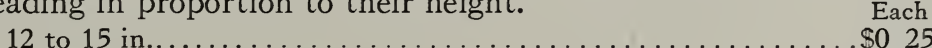

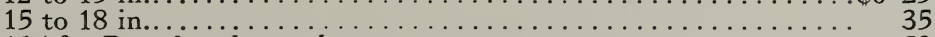

$11 / \mathrm{ft}$.

$2 \mathrm{ft}$. Broad and very heavy.

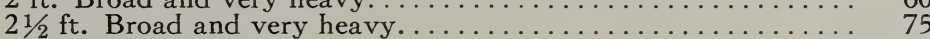

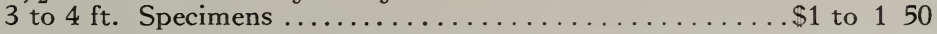

$10 \quad 100$

$\$ 175 \quad \$ 12 \quad 50$

$250 \quad 1500$

3502000

$450 \quad 2500$

NO CHARGE FOR PACKING 
Common Barberry

Berberis vulgaris

The graceful, arching branches are loaded with bright red fruits in the fall following the pretty yellow spring flowers.

3 to $4 \mathrm{ft} . . . . . . .$.

Each $10 \quad 100$

4 to $5 \mathrm{ft}$. Heavy.

.$\$ 0 \quad 50 \quad \$ 400 \quad \$ 2500$

Purple-leaved Barberry

Berberis vulgaris, var. purpurea

Effective, dark, reddish purple foliage; bright red fruits. Each $10 \quad 100$

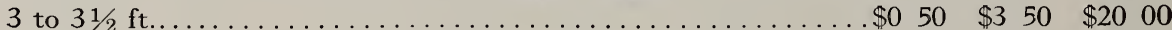

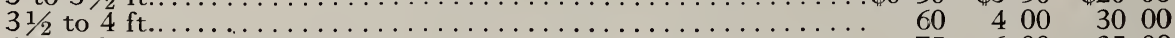

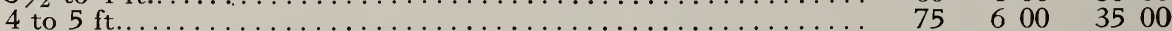

Beauty Fruit

Callicarpa purpurea

Vivid violet-colored berries cover the graceful low branches in the fall.

$11 / 2$ to 2 ft. Each 10

$\$ 050 \$ 350$

American Hazel

Strong-growing border shrub, bearing hazelnuts.

Corylus americana

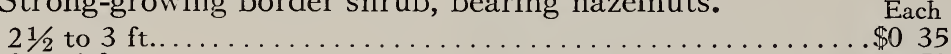

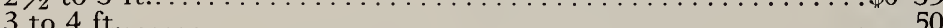

$10 \quad 100$

4 to $5 \mathrm{ft}$.

Corylus avellana, var. laciniata

Cut-leaved Hazel

A very ornamental variety.

5 to $6 \mathrm{ft}$........

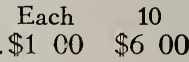

\section{Purple-leaved Hazel}

Corylus maxima, var. purpurea

A Iarge, bronze purple-leaved shrub for the border or specimen; very hardy.

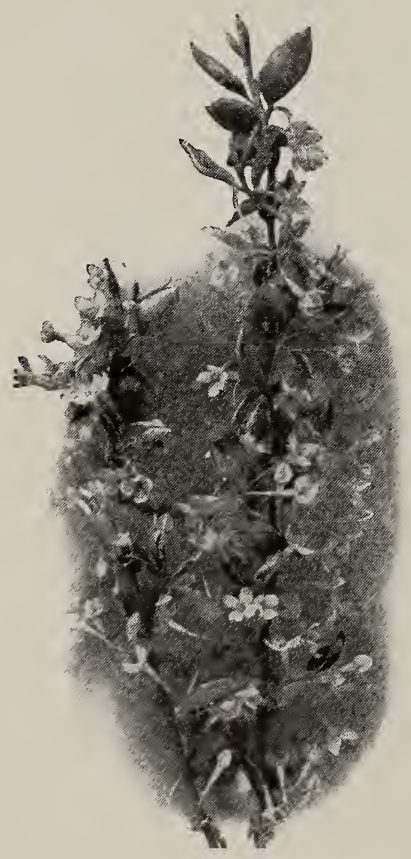

Elæagnus longipes

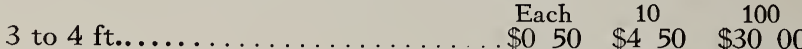

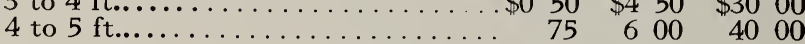

Russian Olive

Elæagnus angustifolia

The silvery gray twigs and under side of the Ieaves, combined with the yellow berries, make this tall shrub very distinctive.

Each $\quad 10 \quad 100$

4 to $5 \mathrm{ft} . \ldots \ldots \ldots \ldots \ldots \ldots \ldots \ldots \ldots \ldots \ldots \ldots$

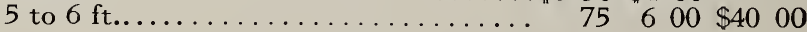

\section{Goumi, or Japanese Oleaster}

Elæagnus longipes (edulis)

Coupled with an attractive, open habit of growth, this tall shrub has the feature of bearing pretty cherry-like red fruits in late summer; most attractive.

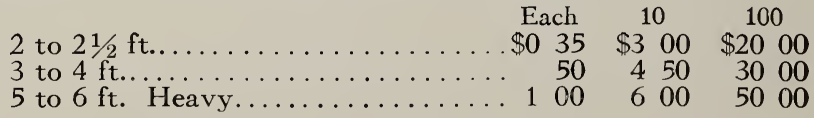

Himalayan Silver Thorn Elæagnus parvifolia

Distinctive, like the others, for silvery foliage and pretty fruits; tall-growing. $\quad$ Each $10 \quad 100$

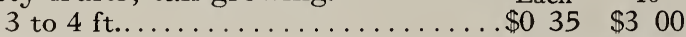

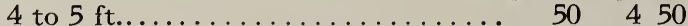

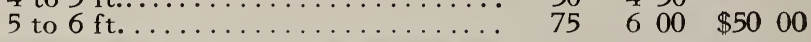




\section{Cork-barked Burning Bush}

Euonymus alata

A veritable burst of flame in the autumn border, when the dark green leaves turn to a wonderful shade of warm crimson; then, too, it is covered with bright coral-red berries, strikingly effective in the winged twigs and branches. A hardy, strong-growing shrub that is equally in keeping in border, or garden, or as a specimen; decidedly Japanese in character. These plants are broad, handsome specimens of exceptionally wide spread.

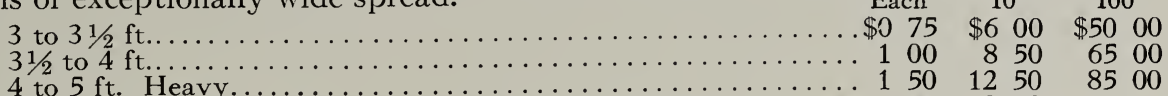

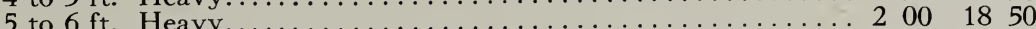

\section{Burning Bush}

Euonymus atropurpurea

An erect shrub valuable for planting among evergreens for its bright red and scarlet berries.

2 to $3 \mathrm{ft} \ldots \ldots \ldots \ldots \ldots \ldots \ldots \ldots \ldots \ldots$

\section{Spindle Tree}

\section{Euonymus europæa}

Very tall, erect shrub for border or evergreen bed; bright scarlet fruit.

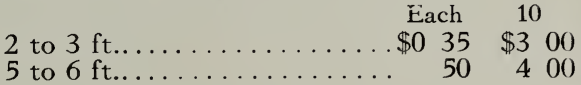

\section{Witch-hazel}

\section{Hamamelis virginiana}

Notable for its wealth of delicate yellow flowers appearing in late fall; exceptionally pretty at the edge of a wood or along woodland paths.

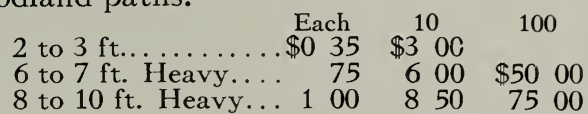

\section{Japanese Winterberry}

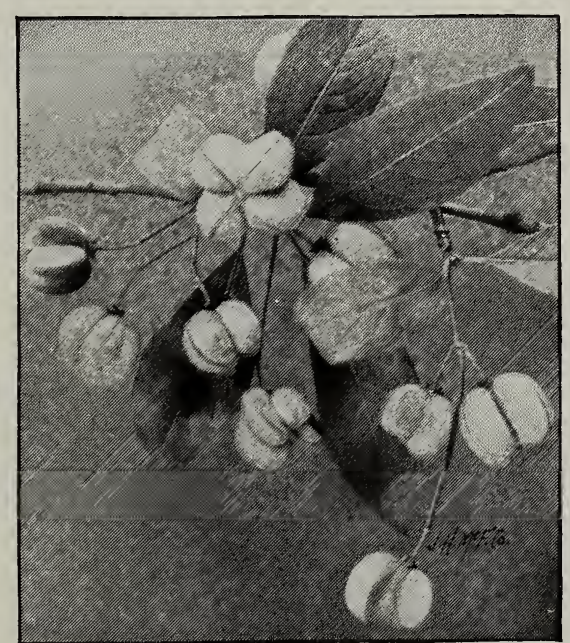

Euonymus europæa

Ilex sieboldii

Of the many interesting introductions from Japan, this beautiful shrub stands out as preëminent for its wonderful display of bright red, holly-like berries, which thickly crowd every twig. It is of slow growth and capitally suited for planting in evergreen beds or borders, where its beauty is doubly enhanced. The berries remain till late in the fall. The white-fruited variety is equally pleasing, especially when planted with the red-berried sort.

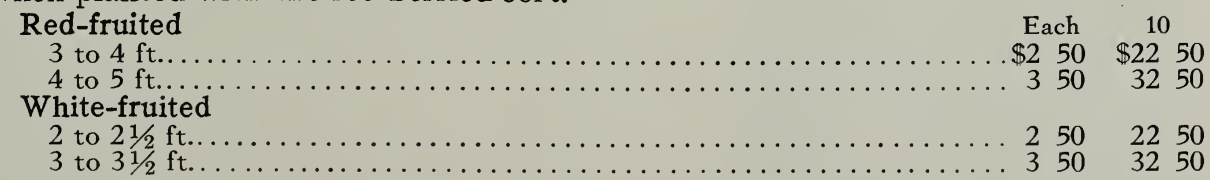

\section{American Winterberry}

Ilex verticillata

TaII-growing shrub, with pretty sprays of bright red berries Iasting till early winter; thrives best in moist situations. It is one of the finest shrubs for planting in connection with Hemlocks, Dogwoods, and Rhododendrons. Its woodsy habit allows it to adapt itself to the close proximity of other plants, and against the heavy foliage of the evergreens the faIl and winter effect of its red berries is most pleasing.

2 to $3 \mathrm{ft}$. Bushy 
Red Chokeberry Pyrus (Aronia) arbutifolia, var. brilliantissima Bright red berries enhance the value of this low border shrub.

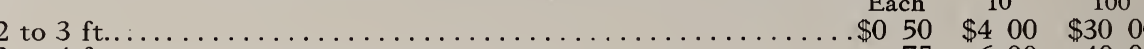

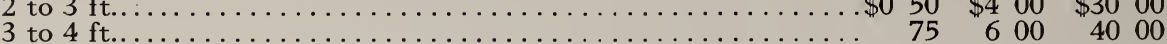

\section{Black Chokeberry}

Pyrus (Aronia) floribunda, var. migra

Glossy black fruits; a low-growing shrub.

Each 10

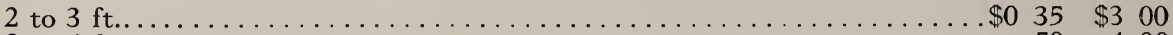

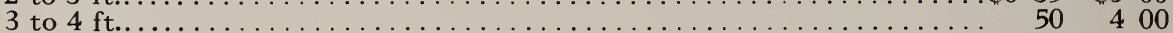

Buckthorn

Rhamnus cathartica

A stiff, twiggy, tall shrub which makes a capital hedge or a good border shrub.

Each $10 \quad 100$

2 to $3 \mathrm{ft}$.

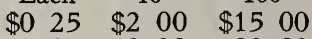

5 to $6 \mathrm{ft}$

$00 \quad 2000$

ant Sumac

Rhus aromatica

This shrub and the one following take on the most brilliant shades of red and crimson foliage in the faIl. Both are of medium height and have showy scarlet fruit.

2 to $3 \mathrm{ft}$.

$\begin{array}{lll}\text { Each } & 10 & 100\end{array}$

3 to $4 \mathrm{ft}$

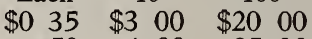

Shining Sumac

Rhus copallina

One of the neatest appearing of the Sumacs; a Iarge shrub offering great attraction for fall and winter effects in foliage and fruit. Few shrubs will be found as satisfactory for dry waste places and bank planting. It thrives in light soils and even in sand wastes. It holds its rich foliage and should always be considered when a thoroughly satisfactory cover plant is needed.

3 to $4 \mathrm{ft}$.

Each

10

100

$\begin{array}{rrrr}50 & 400 & 2000\end{array}$

75

600

2500

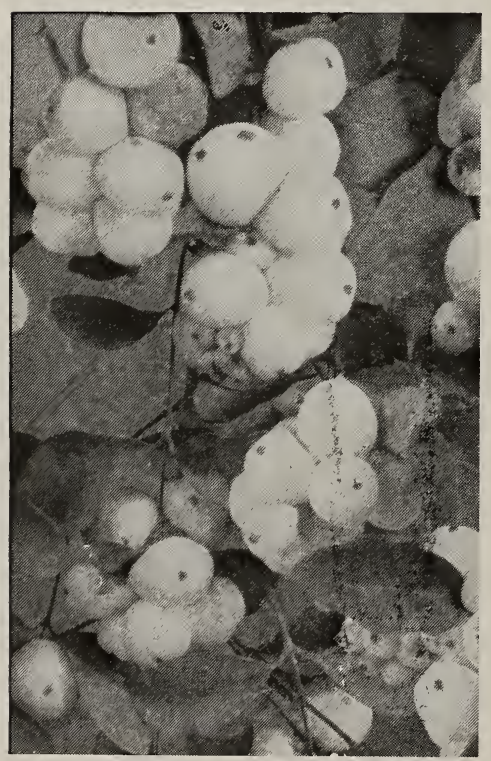

Symphoricarpos racemosus

\section{Snowberry}

Symphoricarpos racemosus

Srow-white berries on delicately arching branches assure this low shrub a place in every border; an old-fashioned plant which gives its best effects planted in masses, and as it is a lowgrowing type, this should be in the foreground of heavier plantations. One of its chief advantages is its ability to hold good foliage during late fall, thus forming a splendid background for the large creamy white berries and setting them off most attractively.

2 to $3 \mathrm{ft}$

Each $10 \quad 100$

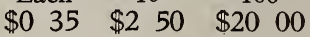

\section{Coral Berry, or Indian Currant}

Symphoricarpos vulgaris

One of the best low shrubs for very shady situations; equally good in broad sunlight, especially for covering banks where its thickly matted roots prevent washing of the soil; has attractive red fruits.

Each $10 \quad 100$

2 to $3 \mathrm{ft} . \ldots \ldots \ldots \ldots \ldots \ldots \$ 25 \quad \$ 200 \quad \$ 1000$

3 to $4 \mathrm{ft} . \ldots \ldots \ldots \ldots \ldots \ldots \ldots$ 35 $300 \quad 1500$ 


\section{Ground-Covers and Special-Purpose Shrubs}

$\mathrm{O}$ FTENTIMES an unsightly slope, which is a source of trouble on account of the surface slipping or washing during heavy rains, can be made attractive by planting low-growing shrubs, whose interlacing roots and tops will also hold the soil. Among the plants valuable for this purpose, besides those listed here, are the varieties of Climbing Honeysuckle, Forsythia suspensa, all the low-growing single Roses found under spring- and summer-flowering shrubs, and especially Rosa wichuraiana, the Japanese Trailing Rose, and its hybrids.

Then again, the neatness and beauty of most evergreen plantings can be enhanced by a very low ground-cover; and for this purpose we find most useful, Japanese Spurge, all the varieties of Japanese Ivy, Euonymus, Periwinkle or Myrtle, Aaron's Beard, and the English Ivy, which as a trailing plant is often hardy where it winter-kills when trained on a wall.

\section{Sweet Fern}

Comptonia asplenifolia

Adapted to planting in dry, gravelly soils for ground-cover; low-growing with aromatic foliage.

18 to 24 in

Each $10 \quad 100$

$\begin{array}{llllll}\$ 0 & 50 & \$ 3 & 50 & \$ 25 & 00\end{array}$

Box Thorn, or Matrimony Vine

Lycium chinense

Its long, arching branches, rising from the ground, make it valuable for use on steep banks or to hang over the top of retaining walls. It is rapid spreading and Iow, with a profusion of coral-red berries in fall.

2 to $3 \mathrm{ft}$......

Each $10 \quad 100$

3 to $4 \mathrm{ft}$

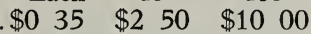

Wax Myrtle

Myrica cerifera

A valuable low shrub for planting in poor soil as a ground-cover. Very beautiful dark green leaves and pretty, gray winter berries closely hugging the stem.

12 to 15 in

Each

10

100

15 to 18 in.

$\$ 050$

$\$ 400$

500

Yellow Root

Xanthorrhiza apiifolia

As an underplanting of high shrubs or as a ground-cover in any moist, shady place, this low, spreading plant is unexcelled. It is beautiful in the fall on account of the coloring of its rich yellow foliage.

6 to 8 in..

Each $\quad 10 \quad 100$

10 to 12 in.

.\$0 $25 \quad \$ 200$

Low-bush Honeysuckle

Diervilla trifida

This low, spreading shrub, bearing attractive little yellow flowers along the branches, is particularly useful in large masses for clothing slopes, or may be used in the shrubbery.

$11 / 2$ to $2 \mathrm{ft}$

Each

$\$ 035$

10100

2 to $3 \mathrm{ft}$. .

50

$\$ 200 \quad \$ 1500$

$400 \quad 2000$

Shrubby Honeysuckle

Diervilla sessilifolia

Higher-growing than the above; yellow flowers in clusters; usefuI in the same way.

Each $\quad 10 \quad 100$

2 to $3 \mathrm{ft}$

$\$ 025$

$\$ 200 \quad \$ 1500$

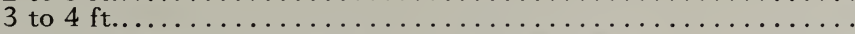

$50 \quad 350$

2000

NO CHARGE FOR PACKING 


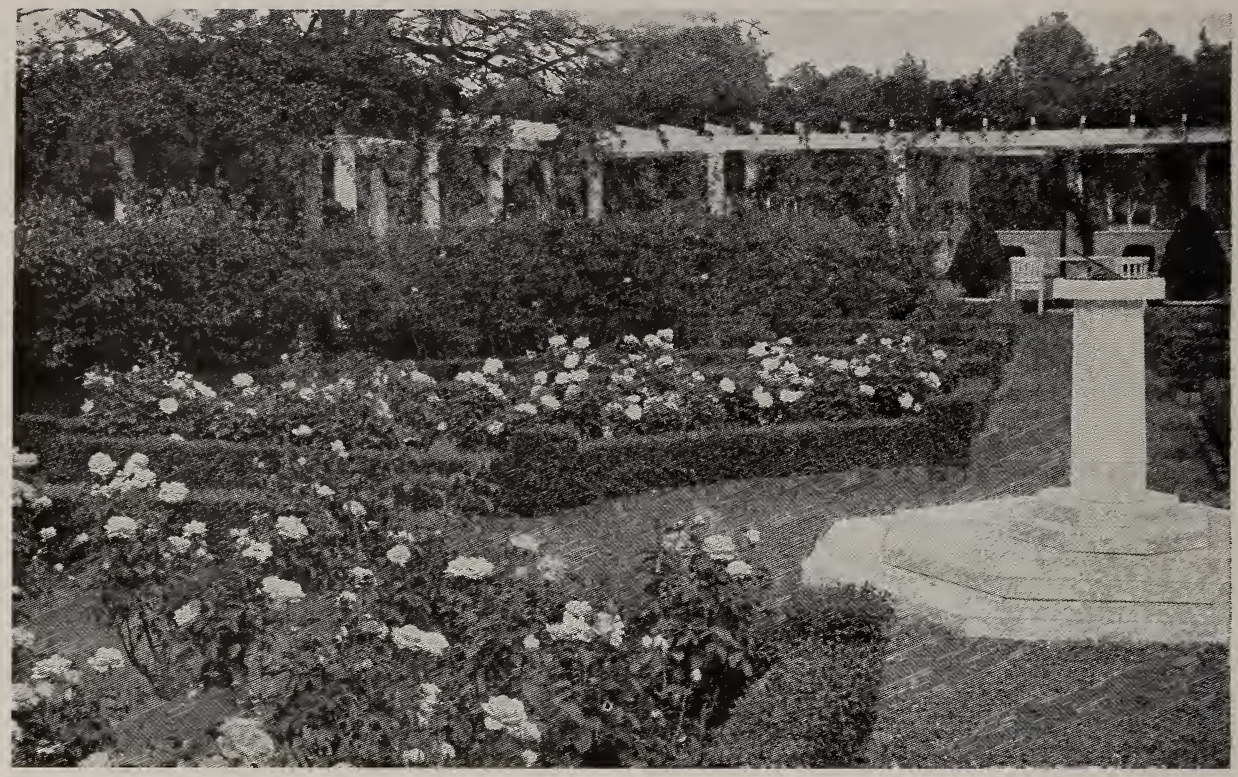

\section{Roses}

ROM the earliest times we know that where any attempt at gardening was made at all, great dependence was Iaid on the Rose. The Persian garden has handed down a race of Roses and the medieval gardens gave us others and so down to the present time gardeners have vied with each other to produce new and wonderful varieties of the classic plant. In consequence there is now a Rose for every situation; the single Roses for the shrubbery border, the trailing Roses for covering steep banks, the old-fashioned Moss Roses, the Hybrids, and the Everblooming Tea Roses for the garden.

\section{CULTURAL DIRECTIONS}

Preparation of the Ground. Always select an open, sunny place, exposed to full light and air. Roses appear to best advantage when planted in beds or masses. Roses will grow in any fertile soil, but are much improved in bloom, fragrance, and beauty by rich soil, liberal manuring, and good cultivation. The ground should be subsoiled and well spaded to the depth of 2 feet or more, and enriched by digging-in good cow-manure or other good fertilizing material. Roses are gross feeders and require a quantity of manure. Renew old beds by decayed sods taken from old pasture-land.

Planting. When the ground is thoroughly prepared-fine and in nice condition-put in the plant slightly deeper than it was before, spread the roots out evenly in their natural position, and cover them with fine earth, taking care to draw it closely around the stem, and pack firmly with the hand. It is very important that the earth be tightly pressed down on the roots. Budded Roses should be planted 3 inches below the bud, but in all cases avoid deep planting. A mulch of litter will be found very beneficial.

WATERING. If the ground is dry when planted, water thoroughly after planting, so as to soak the earth down below the roots, and, if hot or windy, 
it may be well to shade for a few days. After this not much water is required, unless the weather is unusually dry.

Pruning. Old and decayed branches and at least half the previous season's wood should be cut away early each spring, and a little cuttingback after the first blooming will insure more late flowers. Climbing and Pillar Roses should not be cut back; but the tips of the shoots only should be taken off, and any weak or unripe shoots cut out altogether.

\section{FALL AND WINTER TREATMENT}

In the fall the Rose-beds should have a good dressing of stable manure or other fertilizer. The winter rains will carry the strength to the roots, and the remaining matter makes a nice mulch, which in many places is all the protection necessary. Where the winters are not very severe, tender Roses may be covered with clean rye-straw, leaves, or evergreen branches, not too thickly, but so as to permit considerable circulation of air and not to retain water; nothing should be used that will ferment, heat, or rot. The object of covering is to break the force of sudden and violent changes, particularly in March, when the plants should be protected from the sun, rather than from cold, the sudden thawing of the frozen wood doing the damage.

\section{BOOKS ON ROSE CULTURE}

For those who wish to go more thoroughly into the fine points of Rosegrowing we recommend the Manual of the American Rose Society, which is supplied with a year's membership for $\$ 1$. For a more elaborate work we suggest the "Practical Book of Outdoor Rose-Growing," by George C. Thomas, $\mathrm{Jr}$., the price of which is $\$ 4$. We shaII be very glad to supply either of these books at the above figures.

\section{Briar Roses}

Many positions in the Rose border require large-growing Roses and the Briars fill the need perfectly, as they require plenty of room and but little attention; and indeed the shrubbery borders cannot be overlooked when placing Briar Roses, for their midsummer bloom brightens the shrubbery

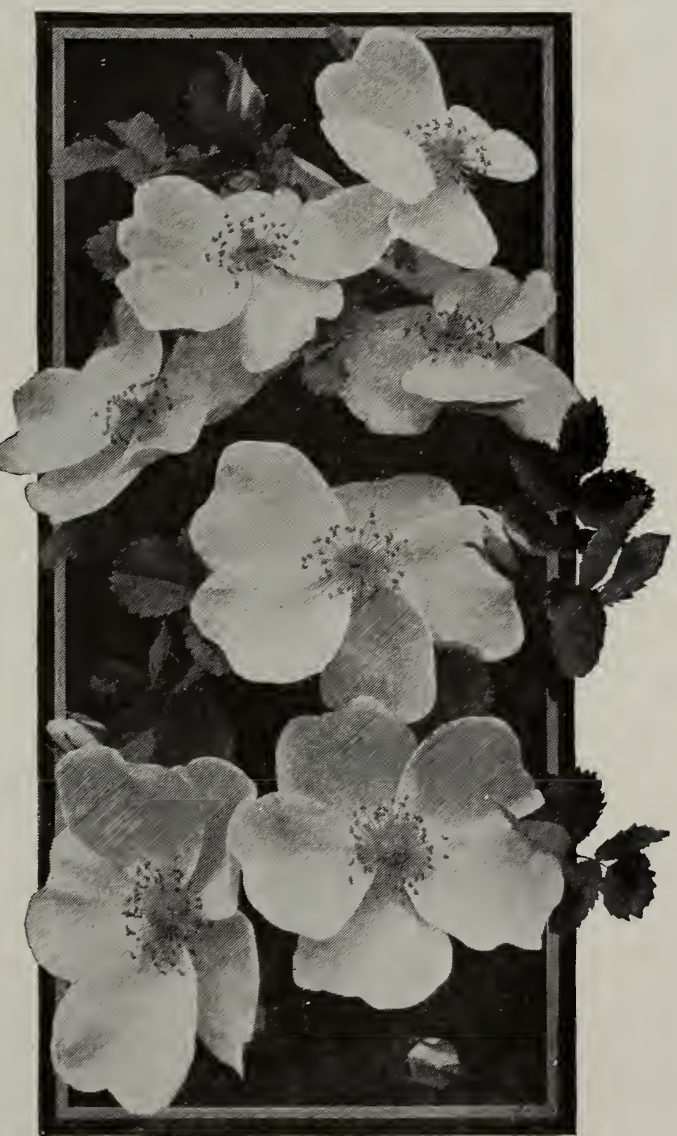

Scotch Briar (Rosa spinosissima) see page 142 
BRIAR ROSES, continued

at a time when most of the hardy bloom is passing. Thus they help to give us a much-desired "continuation" of bloom in the border.

Harison's Yellow. Flowers of medium size and semi-double; color golden yellow. A free bloomer.

40 cts. each, $\$ 3.50$ for 10 .

Persian Yellow. Austrian Rose. Perfectly hardy; flowers double and full, deep golden yellow in color; blooms very freely in June. Remove the weakly wood altogether, and shorten only a few inches the shoots left for flowering. If pruned close, it will not bloom, as the flowers are produced from the terminal shoots of the old wood.

40 cts. each, $\$ 3.50$ for $10, \$ 25$ per 100 .

Scotch Briar (Rosa spinosissima). Of low growth and dense twiggy habit, the branches thick with thorns, foliage bright green, flowers white or blush to pink.

35 cts. each, $\$ 3$ for $10, \$ 20$ per 100 .

Sweet Briar (R. rubiginosa). A charming shrub Rose of dense growth, fragrant foliage, bright pink flowers in June, followed by large orange-red and scarlet fruits. Should be in every shrubbery border. 40 cts. each, $\$ 3.50$ for $10, \$ 30$ per 100 .

\section{ROSA RUBIGINOSA HYBRIDS (PENZANCE BRIARS)}

Amy Robsart. Lovely deep rose; an abundant bloomer; robust and free.

Anne of Geierstein. Dark crimson; foliage Iarge, a good grower, with graceful branching habit.

Brenda. Maiden's blush, or peach.

Flora McIvor. Pure white, blushed with rose.
Lady Penzance. Beautiful soft tint of copper; very free-flowering.

Lord Penzance. Soft shade of fawn or écru, passing to a lovely emerald-yellow.

Meg Merrilies. Gorgeous crimson; very free-flowering; one of the best.

Minna. Large, pure white, opening with a tint of palest blush.

50 cts. each, $\$ 4$ for $10, \$ 35$ per 100

\section{Native Bush Roses}

Will be found listed on pages 122 and 132 .

\section{Rugosa Roses}

Rugosa Roses are exceedingly useful in rough situations, on banks, or in the general border in connection with other shrubs, where they add a richness of foliage, and their summer bloom, which is followed by the bright fruits or hips, gives an added attraction all through the fall. They are also desirable for hedges, their heavy, dark green foliage making a very effective mass, and they can be easily kept within bounds.

Rosa rugosa. Japanese Roses. These form sturdy bushes, perfectly hardy in the most trying places, standing hot suns well and thriving in dry or sandy soils.

R. rugosa, var. alba, white; rosea, pink; rubra, red.

25 cts. each, $\$ 2$ for $10, \$ 15$ per 100

\section{ROSA RUGOSA HYBRIDS}

Atropurpurea. The flowers are, in the bud state, almost blackish crimson, and pass as they open to maroon-crimson.

Blanc Double de Coubert. A double white form of $R$. alba; Iarge and showy.

Conrad F. Meyer. Very Iarge flowers; color clear silvery rose; very fragrant.
Madame Georges Bruant. Paper-white, large and double, produced in clusters.

Madame Charles Worth. Rosy carmine, semi-double.

Mrs. F. Waterer. Color deep crimson, flowering in great clusters; blooms semidouble; fragrant. 


\section{Everblooming Hybrid Tea Roses}

The following varieties have been well tested and are recommended with confidence that they will give satisfaction. Hardiness, growth, and quality of bloom are the important points for which they have been selected.

Antoine Rivoire. Rosy flesh on yellow ground, shaded with a border of carmine; large, full, beautiful.

Baby Rambler. Crimson.

Bessie Brown. Creamy white, blooms perfectly formed, immense size and substance; highly perfumed.

Betty. Ruddy gold.

Caroline Testout. Satin-rose, with bright center; large, full, very free, sweet.

Chateau de Clos Vougeot. Velvety scarlet, shaded fiery red, changing to dark velvety crimson; very floriferous.

Dean Hole. Silvery carmine, shaded saImon; large, full, fine form.

Duchess of Albany. Deep pink.

Duchess of Wellington. Intense saffronyellow, stained with rich crimson, which, as the flower develops, becomes deep coppery saffron-yellow. Flowers of delightful fragrance.

Earl of Warwick. Soft salmon-pink, shaded vermilion.

Francisca Kruger. (Tea.) Yellow peach.

General MacArthur. Bright crimson; large, full, free-flowering, highly perfumed.

George C. Waud. Orange-vermilion, distinct and beautiful, large, perfect finish, floriferous, strong tea perfume.

Gladys Harkness. Deep salmon-pink, large, highly fragrant.

Grace Molyneux. Creamy apricot with flesh center, Iarge, fine form, floriferous, delicately tea-perfumed.

Gruss an Teplitz. Brightest scarlet-crimson; very free-flowering, "useful for pillars."

Harry Kirk. Bright primrose, amberyellow; perfect form; floriferous and vigorous.

Jonkheer J. L. Mock. Carmine, changing to imperial pink. Blooms are large and highly perfumed.

Kaiserin Augusta Victoria. Beautiful primrose; in every way excellent.

Killarney, Pink. Brilliant color, which is almost crimson in bright weather, while in duIl or cloudy weather the color is pure, deep, rosy carmine; tea-rose perfume.
Killarney, White. Flesh, shaded white, suffused pale pink; large; buds very long and pointed; deliciously perfumed.

Lady Alice Stanley: Deep coral-rose on outside of petals; inside pale flesh; Iarge, fuII; fragrant.

Lady Ursula. Flesh-pink, Iarge, full; great substance; petals large, smooth, circular; delicately tea-perfumed.

La France. Beautiful bright pink; large, full; fine form; free-blooming; very highly perfumed.

Laurent Carle. Brilliant velvety carmine; very large.

Madame Abel Chatenay. Carmine-rose, shaded with salmon; very free-flowering.

Madame Jules Bouche. White, center shaded pink; large, full, and perfectly formed; free-flowering.

Madame Leon Paine. Silvery salmon, center orange-yellow; large, full, wellformed; free-flowering.

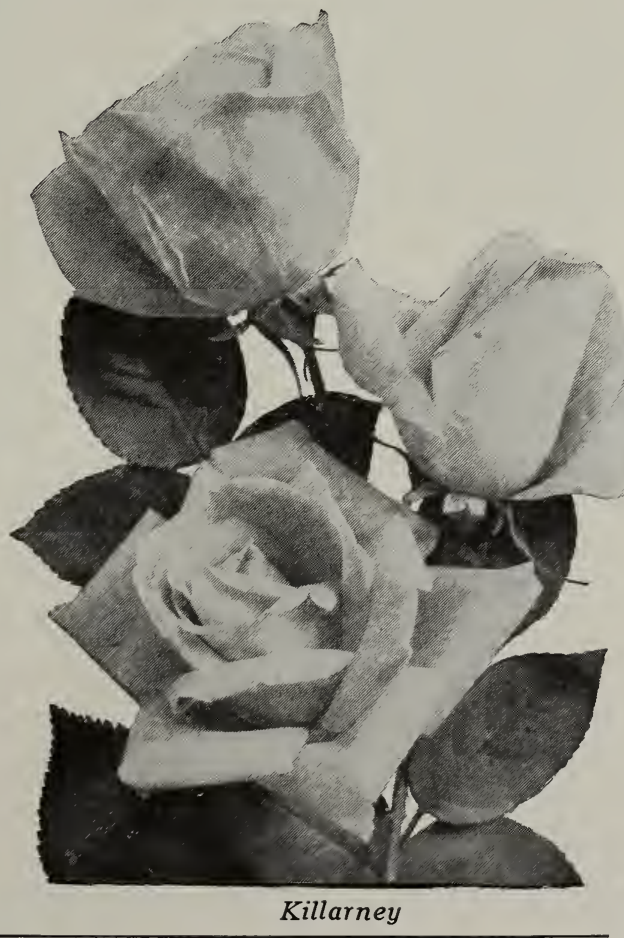


EVERBLOOMING HYBRID TEA ROSES, continued

Madame Ravary. Beautiful orange-yellow; medium.

Madame Segond Weber. Rosy salmon; large form, very fine.

Maman Cochet. Carmine, mingled with salmon-yellow; Iarge, full.

Mrs. Aaron Ward. Indian yellow, occasionally washed with salmon-rose; very floriferous.

Mrs. A. R. Waddell. Reddish salmon, reverse of petals rosy scarlet; semidouble; "fine for bedding."
Mrs. Harold Brocklebank. Creamy white, center buff, outer petals frequently tinted with salmon-rose; buds with a flush of salmon-pink; large, full, perfect form, sweetly perfumed.

Mary, Countess of Ilchester. Warm crimson-carmine; Iarge, with large smooth circular petals; hybrid-tea perfume.

Souvenir du President Carnot. Flesh, shaded white; large and full.

Viscountess Folkestone. Creamy pink, center deep salmon-pink, very floriferous.

$50 \mathrm{cts}$. each, $\$ 4$ for $10, \$ 30$ per 100

\section{Hybrid Perpetual Roses}

These were the garden favorites of twenty years ago, and although the Everblooming Hybrid Teas have gained a large list of friends, there are some of the Hybrid Perpetuals with which no garden can dispense. They can be grown in the colder parts of the country where the Hybrid Teas will not stand.

Alfred K. Williams. Carmine-crimson, large, full, globular, free-blooming, fragrant.

Baroness Rothschild. Pale rose, Iarge, cupped-form.

Captain Hayward. Scarlet-crimson, perfect form, sweetly perfumed.

Eugene Verdier. Rose-flesh.

Frau Karl Druschki. White.

General Jacqueminot. Crimson-scarlet, large, fuIl, very fragrant.

Madame Gabriel Luizet. Light silvery pink, large, full.
Magna Charta. Bright rose, very large, full.

Margaret Dickson. White, pale flesh center; large, fine form.

Mrs. John Laing. Soft pink, very Iarge, fine form; floriferous, very fragrant.

Mrs. R. G. Sharman-Crawford. Deep rosy pink, outer petals shaded pale flesh.

Paul Neyron. Deep rose. Enormous size.

Prince Camille de Rohan. Deep veIvety crimson; full, fine form.

Ulrich Brunner. Cherry-crimson, Iarge.

50 cts. each, $\$ 4$ for $10, \$ 30$ per 100

\section{Dickson's Hybrid Single Roses}

In our nurseries there are no more attractive objects than the Irish single varieties, and they are so marvelously free-flowering that it is impossible to say too much in their praise. During the entire growing season they are virtually always in bloom, and their lasting properties are most surprising. The shrubby border calls for them.

Irish Beauty. Pure white, with distinct and prominent bright golden anthers; large, free-flowering, deliciously fragrant.

Irish Elegance. Bronzy orange-scarlet, which whilst expanding assumes varied apricot hues. Profuse bloomer from early June until the end of the flowering season.
Irish Brightness. Vivid crimson, shading pink at base of petals.

Irish Harmony. Saffron-yellow, crayoned or smeared claret; the flowers when expanded being creamy wnite, of large size; very free-flowering.

Irish Modesty. Delicate coral-pink suffused from base of petals with écru; large and very plentifully produced.

75 cts. each, $\$ 6$ for 10 


\section{Climbing Roses}

The Pillar or Climbing Roses are now so generally used that where garden Roses are planted there is always a place for them. The following are excellent pillar, porch, or trellis Roses, and those of the Wichuraianas which are marked with an asterisk $\left(^{*}\right)$ are weIl and favorably known for

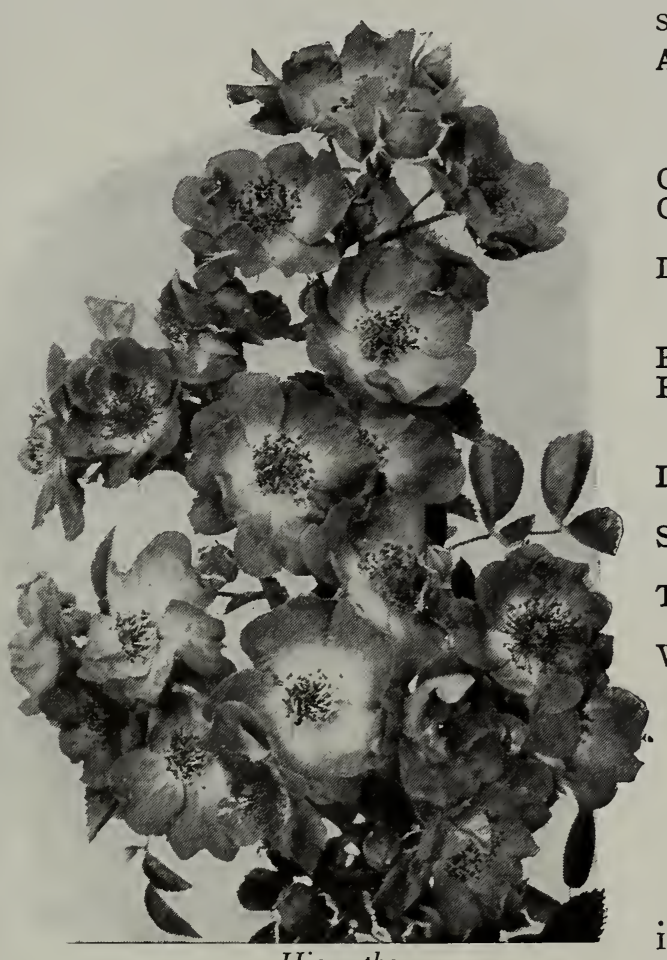
such work.

American Pillar. Lovely shade of pink with a clear white eye, with bright yellow stamens; flowers single and large; they are produced in huge clusters.

Christine Wright. Wild rose-pink.

Climbing American Beauty. Rosy crimson.

Dorothy Perkins. Soft light pink; flowers profusely in Iarge clusters; very fragrant and lasting.

Excelsa. Scarlet-crimson, Iarge clusters.

Hiawatha. Brilliant scarlet, single, flowering in large clusters; most brilliant and effective.

Lady Gay. Cherry-pink color, fading to soft tone; very floriferous.

Silver Moon. Clear silvery white; Iarge. 75 cts. each.

Tausendschon. Pink, rosy carmine when expanded; Iarge clusters.

White Dorothy Perkins. Pure white sport from Dorothy Perkins, having all its fine qualities.

50 cts. each, $\$ 4$ for $10, \$ 35$ per 100

\section{Trailing Roses}

Where ground-cover is needed in borders and on banks, either in the open or under trees, anywhere that a good foliage and a trailing plant can be used, these Roses recommend themselves for the purpose. Their branches lie flat upon the ground and they form dense masses of foliage.

Wichuraiana. White; rich deep green foliage. The stems keep flat on the ground, thus making a deep dense carpet of green, against which the white flowers bloom in masses. 2 to $3 \mathrm{ft}$., 2 years old, 4 -in. pots, 35 cts. each, $\$ 3$ for $10, \$ 25$ per 100.

\section{WICHURAIANA HYBRIDS}

Adelaide Moulle. Soft pink.

*Alberic Barbier. Creamy white and canary-yellow in the middle; buds of a darker yellow color; semi-double, flowers in clusters.

Auguste Barbier. Rosy crimson.

*Debutante. Rosy pink, large clusters.

Eliza Robichon. Rose, shaded pale yelIow; semi-double; floriferous.

Evergreen Gem. Buff in the bud, changing to creamy white; very double.

*Gardenia. Buds bright yellow; open double flowers of cream color.
Manda's Triumph. Flowers double, pure white, and 2 inches in diameter, are well formed, very fragrant, and borne in clusters.

Paul Transon. Rosy pink.

Pink Roamer. Flowers rich pink with almost white centers and orange-red stamens.

South Orange Perfection. Grows closer to the ground. Flowers double; soft blushpink at the tips, changing to white.

Universal Favorite. Vigorous. Fragrant double flowers, of a soft rose-color.

50 cts. each, $\$ 4$ for $10, \$ 35$ per 100 


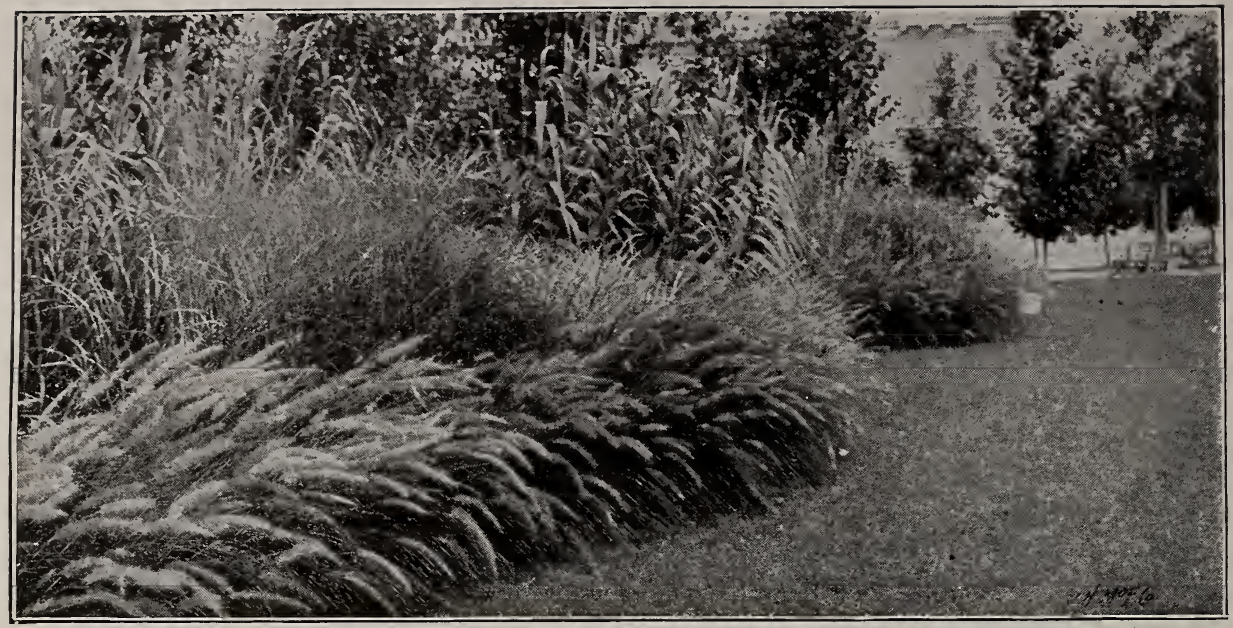

\section{Reeds and Ornamental Grasses}

These are always appropriate for waterside planting, and are sometimes very effective in the shrubberies and informal arrangements.

Giant Reed

Arundo donax

Very tall-growing, the canes of this plant often attaining a height of 12 to 15 feet. Effective at the waterside.

50 cts. each, $\$ 3.50$ for 10 .

\section{Lyme Grass}

Elymus glaucus

Hardy, 3 to 5 feet, excellent for edging shrubbery beds. 25 cts. each, $\$ 1.50$ for 10 .

\section{Dwarf Bamboo}

Bambusa metake

Grows from 5 to 8 feet in height, and has bright green, palm-like foliage. Succeeds weIl in almost any situation, and is excellent for planting on steep banks.

50 cts. each, $\$ 3.50$ for $10, \$ 30$ per 100 .

Erianthus

Erianthus ravennæ

Grows 9 to 12 feet high, frequently throwing up from 30 to 50 flower-spikes.

50 cts. each, $\$ 3.50$ for 10 .

Eulalia

Eulalia japonica

The foliage is deep green, and in autumn it bears Iong flower-spikes of purplish brown flowers.

50 cts. each, $\$ 3.50$ for 10 .

\section{Variegated Eulalia}

Eulalia japonica, var. variegata

The Iong narrow leaf-blades are striped with a broad band of white.

50 cts. each, $\$ 3.50$ for 10 .

Graceful Eulalia

Eulalia japonica, var. gracillima univittata Leaves narrow, giving the plant a very graceful habit. $50 \mathrm{cts}$. each, \$3.50 for 10 .

Barred Eulalia

Eulalia japonica, var. zebrina

The Iong leaf-blades are marked across the leaf with broad, regular bars of yellow.

50 cts. each, $\$ 3.50$ for 10 .

Pampas Grass

Gynerium argenteum

Requires protection; its Iarge, silvery white plumes produced on stems 6 to 8 feet in height.

50 cts. each, $\$ 3.50$ for 10 .

\section{Ribbon Grass}

Phalaris arundinacea, var. variegata

A dwarf grass; foliage striped with white. Excellent for bordering shrubberies or beds of grasses.

25 cts. each, $\$ 1.50$ for 10 . 


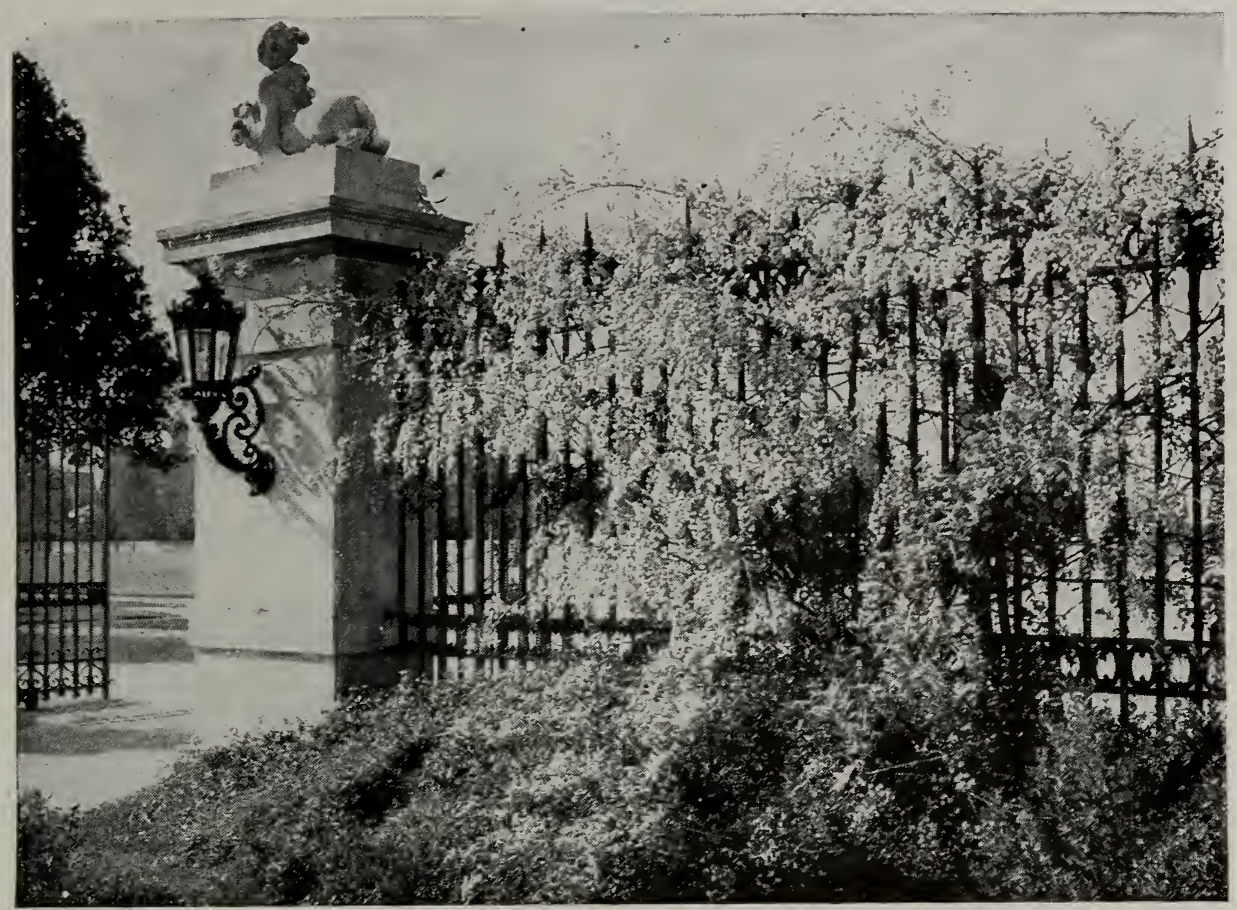

Chinese Wistaria covering fence

\section{Vines}

Every place has a need, a position for vines - the walls of the house and gardens, the fence, trellis, arbor, or tree trunks which have lost the protection of their branches and stand gaunt and bare.

The selection of appropriate vines is sometimes a problem, as many sorts serve more than one purpose. We have, therefore, thought it best to list the Vines in alphabetical order and place an index number on each sort, referring to its adaptability, and if more than one purpose is mentioned, to place first the index of the chief purpose.

The following numbers will serve to indicate the use to which each Vine is most appropriate:

(1) For walls of buildings.

(2) For rough walls and garden walls.

(3) For porches, fences, trellises, or arbors.

(4) For tree trunks.

(5) For large arbors and pergolas where growth is needed on a Iarge scale.

(6) For ground-work on banks.

(7) For carpeting under trees.

\section{Actinidia}

Actinidia polygama

3, 4, 5. Strong climber of exceptional value where a quick-growing, clean-foliaged plant is desired. Foliage glossy green; flowers white with a purple center in July, followed by yellow fruits.

50 cts. each, $\$ 3.50$ for 10 .

\section{Akebia}

Akebia quinata

3. A charming climber, with shining, almost evergreen foliage and clusters of chocolate-colored, fragrant flowers in June, followed by dark purple berries.

50 cts. each, $\$ 3.50$ for 10 . 
Virginia Creeper

Ampelopsis quinquefolia

$2,3,4,5$. A native, very hardy and of extremely rapid growth. The beautiful leaves are deeply cut and turn to rich crimson in the autumn.

\section{Engelmann's Woodbine}

25 cts. each, $\$ 2$ for $10, \$ 15$ per 100 .

Ampelopsis quinquefolia, var. Engelmannii

2, 3, 4, 5. Similar to A. quinquefolia, but of somewhat more clinging habit, and with smaller, denser foliage. Colors beautifully in the fall.

25 cts. each, $\$ 2$ for $10, \$ 15$ per 100 .

Boston Ivy

Ampelopsis tricuspidata; syn. Veitchii

1, 2. Possibly the best known of all climbers. When once established it grows with great rapidity and clings very closely to any surface. The leaves are broad, dark green, and glossy, and in the fall color rich crimson. $\quad 25$ cts. each, $\$ 2$ for $10, \$ 15$ per 100 .

\section{Pipe Vine}

Aristolochia sipho

4, 5. A strong grower, with huge thick and shining cordate leaves of a pretty light green, 6 to 12 inches across, and hanging so that they overlap each other. It bears curious purplish pipe-shaped flowers.

75 cts. each, \$6 for 10.

\section{Trumpet Vine}

Bignonia grandiflora

3, 5. A strong, rapid grower, of rather bushy habit, and bearing large flowers of brilliant orange-red in July. It blooms earlier than $B$. radicans.

35 cts. each, $\$ 2.50$ for 10 .

\section{Scarlet Trumpet Vine}

Bignonia radicans

$2,3,4,5$. One of the strongest and most ornamental climbing vines. Its foliage is a deep, rich green, and flowers dark rich crimson. It is of much more rapid growth than $B$. grandiflora and clings much closer.

35 cts. each, $\$ 2.50$ for 10 .

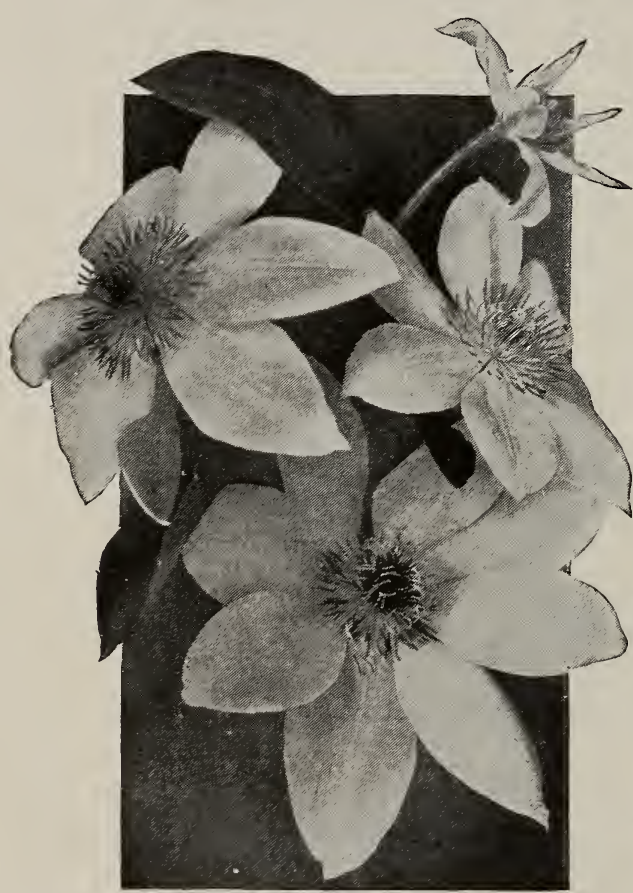

Large-flowered Clematis
Bittersweet

Celastrus scandens

3, 4, 5, 6. A rapid-growing, climbing shrub, with ornamental, light green foliage, yellow flowers in June and bright orange-yellow and crimson fruit in autumn. 50 cts. each, $\$ 3.50$ for 10 .

\section{SMALL-FLOWERED CLEMATIS}

\section{Scarlet Clematis}

\section{Clematis coccinea}

3. A rapid-growing, handsome and hardy sort, with good foliage, and covered from June to late fall with bright coral-red flowers.

35 cts. each, $\$ 3$ for 10 .

\section{Sweet Clematis}

\section{Clematis flammula}

3, 5. A hardy, rapid climber, with small, dark green foliage which remains until late in the winter, and in the early fall the plant is covered with small, white, fragrant flowers. $\$ 1$ each, \$7 for 10 .

\section{Japanese Clematis}

\section{Clematis paniculata}

3, 5, 6. One of the finest and most popular of this class. It is a very vigorous, rapid grower, with handsome foliage, and in late summer is completely covered with dense sheets of medium-sized, pure white flowers. 30c. ea., $\$ 2.50$ for $10, \$ 15$ per 100 . 
Wild Clematis

Clematis virginiana

$3,4,5,6$. A very vigorous, rapid, native climber, bearing in July and through September panicles of pure white flowers.

\section{Heavy-scented Clematis}

Clematis graveolens

3, 4, 5. A strong, rapid climber, with smooth, shining foliage, and bearing in August and September light yellow flowers.

50 cts. each, $\$ 3.50$ for 10 .

\section{LARGE-FLOWERED CLEMATIS}

3. These are the most useful; their perfect hardiness, together with their good foliage and magnificent flowers, makes them a most desirable class of plants. The following will be found the best for general planting:

Duchess of Edinburgh. White; double.

Jeanne d'Arc. Fine white.

Kermesina. Brilliant red.

Fairy Queen. Large flowers, pale flesh with pink bar.

Lady Caroline Neville. French white, mauve bars.

Gem. Sky-blue.

Lilacina floribunda. Pale Iilac.

President. Intense blue.

50 cts. each, \$4 for 10.

Henryi. Creamy white, large and handsome.

Madame Van Houtte. Pure white, extra fine.

Jackmanii. Large, rich violet-purple; a free bloomer; most popular.

Miss Bateman. White; a hardy, vigorous grower.

Jackmanii, var. alba. Similar to Clematis Jackmanii, but with pure white flowers.

Evergreen Ivy

Euonymus

Japanese Evergreen Ivy (Euonymus radicans). 1, 2, 4, 6, 7. See pages 59 and 60.

Variegated Japanese Evergreen Ivy (Euonymus radicans, var. variegata). See pages 59 and 60 .

Carriere's Japanese Evergreen Ivy (Euonymus radicans, var. Carrierei). See pages 59 and 60 .

Scarlet-Fruited Japanese Ivy (Euonymus radicans, var. vegeta). See pages 59 and 60.

English Ivy

Hedera helix

$1,2,4,6,7$. See page 60. 4-in. pots........25 cts. each, $\$ 2$ for $10, \$ 15$ per 100 . Extra heavy, 4 -in. pots: ...................

Honeysuckle

\section{HONEYSUCKLES}

Lonicera japonica, var. brachypoda

3, 5. A form with dark green foliage, but not so strong a climber as L. japonica. Flowers yellow and fragrant. $\quad 35$ cts. each, $\$ 2.50$ per 10 .

\section{Golden Honeysuckle}

\section{Lonicera brachypoda, var. aurea reticulata}

3, 5. Chiefly valued for its foliage, which is beautifully marked with deep golden yellow, and in the late fall sometimes marked with rosy pink. 35 cts. each, \$3 for 10 .

\section{Japanese Honeysuckle}

\section{Lonicera japonica}

3, 5. This form is distinguished by its very dark, purplish green foliage; it is almost evergreen, and bears fragrant yellow flowers.

35 cts. each, $\$ 3$ for $10, \$ 20$ per 100 .

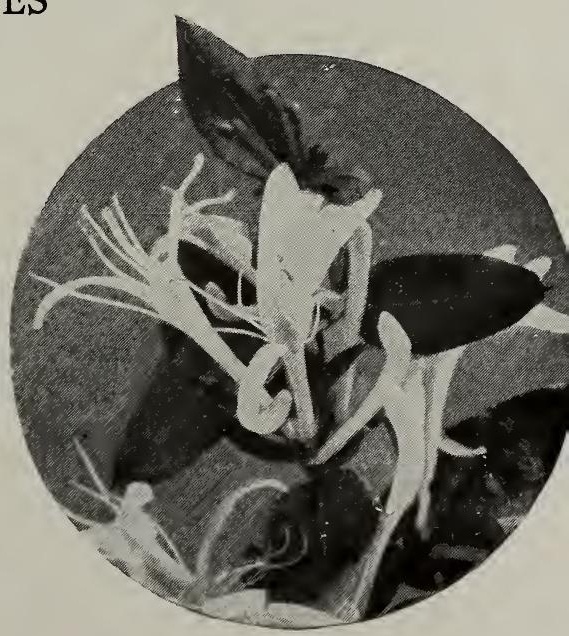

Lonicera japonica

NO CHARGE FOR PACKING 


\section{Hall's Honeysuckle}

Lonicera japonica, var. Halleana

$3,5,6$. A popular and valuable variety, with smooth, glossy, dark green foliage. It flowers Iater than the other sorts and holds its foliage throughout the winter.

4 -in. pots. . . . . . . . . . . . . . . . . . 35 cts. each, $\$ 3$ for 10, \$20 per 100.

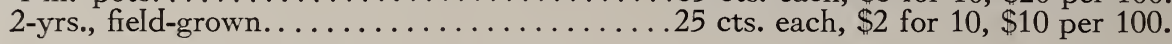

\section{Scarlet Trumpet Honeysuckle}

Lonicera sempervirens, var. fuchsioides

3, 5. One of the showiest and most prolific bloomers, and an excellent climber. It has fine foliage, and through the summer bears large branches of bright scarlet flowers, which are followed by scarlet berries. $\quad 75$ cts. each, \$6 for 10.

\section{Silk Vine}

Periploca græca

3,4 , 5. A strong, rapid grower, with dark green, glossy foliage, and bearing in July small purple flowers. $\quad 50 \mathrm{cts}$. each, $\$ 3.50$ for $10, \$ 25$ per 100 .

\section{Kudzu Vine}

Pueraria thunbergiana

$3,4,5$. Considered the most rapid of all climbers; its leaves are Iarge and handsome, and in Iate August and September it is covered with racemes of pea-shaped flowers of rosy purple color.

50 cts. each, \$4 for 10.

\section{WILD GRAPES}

\section{Summer Grape}

Vitis æstivalis

4, 5. A strong, tall-climbing vine, with large foliage, noticeable for the reddish brown fuzz on the under side of the leaves; the berries are small and black, with a very tough skin.

50 cts. each, $\$ 3.50$ for 10 .

\section{Japanese Grape}

Vitis heterophylla

4, 5. Valued for its ornamental foliage, as the leaves are marked with creamy white; the flower has some fragrance.

75 cts. each, \$6 for 10 .

\section{Fox Grape}

Vitis labrusca

4, 5. A strong, rapid climber, with Iarge thick leaves, full green above, but the under side covered with tawny white or reddish brown tomentum; the berries are large, purplish black to reddish brown, with a musty flavor.

\section{Frost Grape}

50 cts. each, $\$ 3.50$ for 10 .

4. A vigorous grower, with bright green foliage; ers are sweet-scented, and the small berries purplish black with a blue bloom. They ripen late and remain until after frost.

50 cts. each, $\$ 3.50$ for 10 .

\section{WISTARIA}

\section{Blue Chinese Wistaria}

Wistaria chinensis

$3,4,5$. One of the best of all hardy climbers. It thrives in a sunny situation, and when in good soil grows quite rapidly. When in flower in May the great clusters of peashaped fragrant bloom give a more showy effect than any other vine.

2 to $3 \mathrm{ft}$., in Iarge pots..................... \$1.50 each, $\$ 12.50$ for 10.

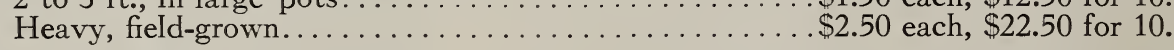

\section{White Chinese Wistaria}

3, 4, 5. Pure white, fragrant flowers.

Wistaria chinensis alba

$\$ 1$ each, $\$ 8.50$ for 10 .

American Wistaria

Wistaria magnifica

3, 4, 5. A native sort, bearing medium-sized panicles of pale lilac-colored, fragrant flowers.

$\$ 1.50$ to $\$ 2.50$ each.

Large-flowered Wistaria

Wistaria multijuga

3, 4, 5. A Japanese species, with immense panicles of deep purple flowers.

$\$ 1$ each, $\$ 7.50$ for 10. 


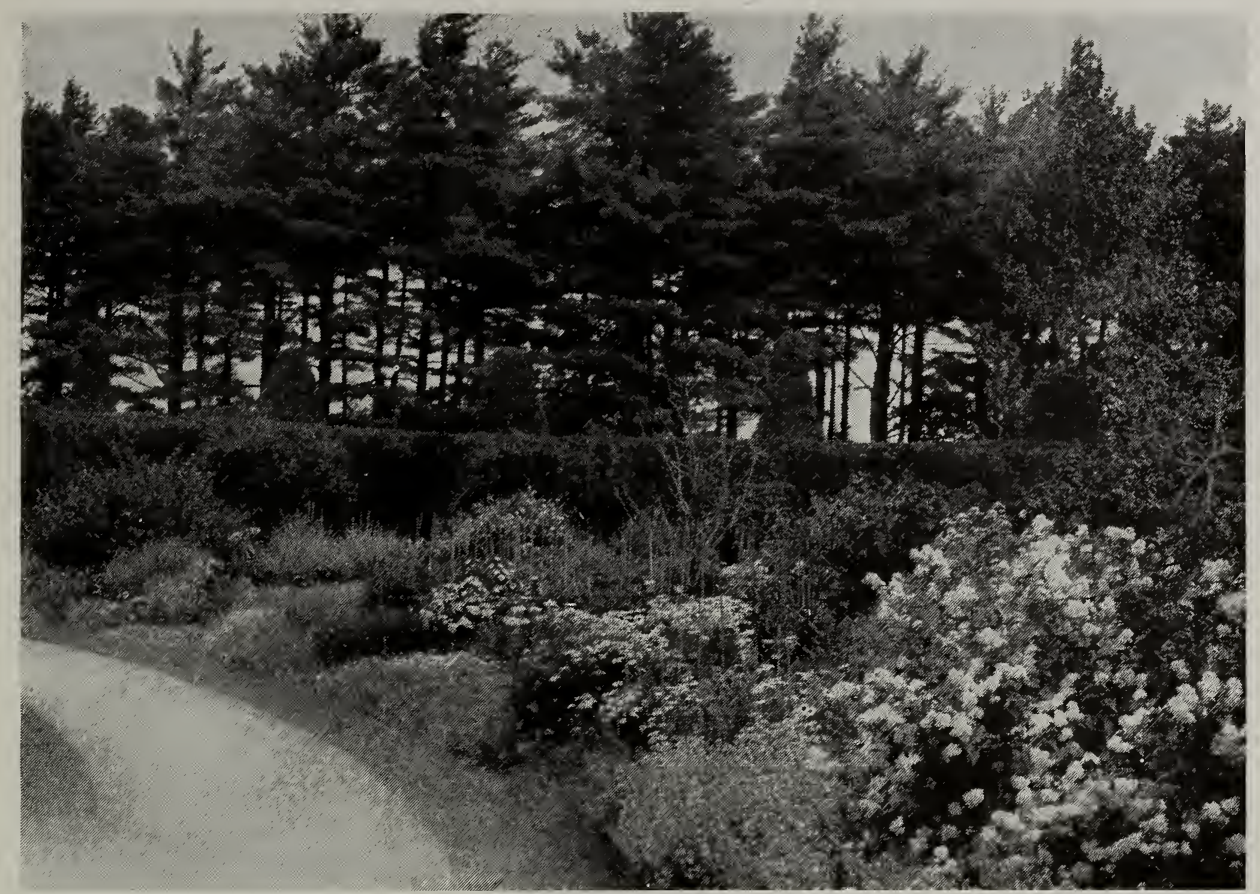

\section{Herbaceous Plants}

\section{PERENNIALS}

T $N$ the past few years the popularity of these garden plants has increased by leaps and bounds: where one was used five years ago a hundred are planted today. 1 We are appreciating more and more the possibilities of this class of plants not only to furnish the general color scheme of the garden but to give us those masses of cut-flowers which we take from the garden to the house.

Indeed these hardy flowering plants cannot be said to be only garden plants for they find a place in the woodland, by the brookside, in the meadow, as pleasing covers for unsightly places under trees, and for the beautifying of rocky banks; in fact, there are few positions where perennials cannot be used to advantage, and as the listing of this class of plants requires more space than we can devote to it in this catalog we have prepared another edition of our

\section{Calendar of Hardy Perennials}

a booklet which first issued in 1905 and of which we have printed numerous editions. In this list will be found not only our best-known garden plants but many that are rare and interesting, and they are classified under the months in which they bloom and in lists for special purposes. One is often anxious for perennials for a special purpose and it is a long journey to take the average perennial catalog and wade through the descriptions to find those which will meet requirements. Our arrangement of Iists takes care of this; you simply turn to the special class and find anywhere from a dozen to fifty varieties that can be used for the purpose, and from which it is easy to make a selection. Do not fail to ask for the "Calendar of Hardy Perennials." 


\section{How to Reach Andorra}

BY RAIL. Chestnut Hill is the terminus of branches of the Pennsylvania Railroad (take train at Broad Street Station) and the Philadelphia \& Reading Railway (take train at the Terminal, 12th and Market Streets). At Chestnut Hill take the trolley which runs to "City Line," within three minutes' walk of the nurseries.

BY AUTOMOBILE. Our Nurseries lie on either side of the Reading Pike at the City Line; this is the motor highway from Reading, Pa., to Philadelphia. From Philadelphia the grounds are readily accessible by a short run north on Broad Street to Branchtown, west to Stenton Avenue, north to the City Line (or Wissahickon Road). Another pleasant route is north on East River Drive, Fairmount Park, thence along the Lincoln Drive, north on McCallum Street, following the well-marked road to the Pennsylvania Railroad Station at Chestnut Hill, thence north on Bethlehem Pike to Stenton Avenue, turn left to City Line and west on City Line.

\section{SHIPPING FACILITIES}

BY RAIL. Two of the largest railroads, the Pennsylvania and the Reading, have stations at our packing-house. Express service is both by Wells Fargo and American.

MOTOR SERVICE. We make free deliveries of all goods within reasonable hauling distance of our nurseries. Deliveries can be arranged for longer distances at a slight cost for hauling, and all less than truck loads within our regular hauling district are delivered two or three times a week, as the loads can be assembled.

\section{SHIPPING INSTRUCTIONS}

ORDERS. AII orders are accepted subject to the following terms and conditions. Write plainly and give explicit directions as to address and mode of shipment.

An order sheet is furnished in the catalog.

FORWARDING. Shipments will be forwarded exactly as directed; but when without instructions, we will use our best judgment and forward by shortest and safest route. We recommend that all herbaceous plants be shipped by express.

RISK. AII goods are at purchaser's risk after they are delivered to the forwarding companies and we receive their receipt for the shipment in good condition.

CLAIMS for damage while in transit must be made to the delivering company. Have delivering agent note the damaged condition on the freight bill and present your claim through him promptly.

SHIPPING SEASON opens about March 1 in the spring and August 15 in the fall.

INSPECTION AND FUMIGATION. Our stock is regularly inspected and certificate will be sent with each shipment. Stock will be fumigated when requested or when the state laws require it.

\section{TERMS}

PRICES given in this list are for the goods $\mathrm{f}$. o. b. here, all packing charges included. STOCK SELECTED by customers at the nurseries will be charged according to the value of the trees chosen.

QUANTITY. Lots of 5 and 50 will be furnished at the 10 and 100 rates respectively.

PACKING. AII goods are thoroughly packed, thus avoiding risk, if delayed in transit. No packing charges in addition to the list prices.

GUARANTEE AND CLAIMS. AII goods are guaranteed true to name, fuIl count, up to grade, and in good condition when shipped. Any plant proving untrue to name will be replaced. Claims to receive consideration must be made within five days after receipt of goods. We give no guarantee of the life of stock.

TERMS, CASH WITH ORDER, except to persons who satisfy us as to their responsibility, when accounts will be due in 30 days.

Address all orders to

\section{ANDORRA NURSERIES}

\section{WM. WARNER HARPER, Prop.}

CHESTNUT HILL, PHILADELPHIA, PA. 


\section{Topical Index}

EVERgReEn Trees

For Landscape Groups, Screens, or Windbreaks

For Specimens . . . . . . . . . . . . . . I3-I6

For Formal Effects . . . . . . . . . . . . . . . . . .

For Informal Plantings . . . . . . . . . . . . . . . . 33

Of Medium Height . . . . . . . . . . . . . . . . 34

Low-growing and Spreading . . . . . . . . . . . . . 38

Flowering Broad-leaved . . . . . . . . . . . . $4 \mathrm{I}$

Broad-leaved, Valuable for Berries, Form, and Foliage . . . 55

For Ground-Covers . . . . . . . . . . . . . . 59

Deciduous TREes

For Street and Roadside . . . . . . . . . . . . . 63

For Specimens . . . . . . . . . . . . . . . $7 \mathrm{I}$

Flowering . . . . . . . . . . . . . . . . 77

For Screens and Windbreaks . . . . . . . . . . . 89

Tall-growing . . . . . . . . . . . . . . . . . . 89

Medium Height . . . . . . . . . . . . . . . 93

Colored-Foliage, Effects with . . . . . . . . . . . 95

Deciduous Conifers . . . . . . . . . . . . . . . . 97

Deciduous Shrubs . . . . . . . . . . . . . . . 99

For Spring Effects . . . . . . . . . . . . . . I I I

Choice Varieties . . . . . . . . . . . . . . IOI

For Spring Flowers in the Shrubbery . . . . . . . . . Iog

For Midsummer Effects . . . . . . . . . . . . I 29

For Fall and Winter Effects . . . . . . . . . . . I35

For Ground-Covers and Special Purposes . . . . . . . 139

Roses . . . . . . . . . . . . . . . . . . . I40

Briar . . . . . . . . . . . . . . . . . . I4I

Penzance Briars . . . . . . . . . . . . . . . 142

Rubiginosa Hybrids . . . . . . . . . . . . . 142

Rugosa . . . . . . . . . . . . . . . . . 142

Everblooming Hybrid Tea . . . . . . . . . . . I 43

Hybrid Perpetual . . . . . . . . . . . . . . I44

Dickson's Hybrid Single . . . . . . . . . . . . I44

Climbing . . . . . . . . . . . . . . . . . 145

Trailing . . . . . . . . . . . . . . . . . 145

Reeds and Ornamental Grasses . . . . . . . . . . 146

VINES . . . . . . . . . . . . . . . . . . I47

NO CHARGE FOR PACKING 


\section{Index to Common Names}

Acacia, Rose...........134

Actinidia ............ 147

Adam's Needle. . . . . . . . . . 53

Akebia.... . . . . . . . . 147

AIder, Black. . . . . . . . . . . 90

Cut-leaved............ 71

European............... 90

Fern-leaved.......... 71

Speckled.......... 90

Allspice. . . .

.110

Althea.

130,131

Andromeda, Drooping... . 52

Angelica Tree, Chinese. . . 90

Aralia, Bush........... 109

Arborvitæ, American... . . 26

Bronze Siberian....... 27

Compact Oriental...... 19

Douglas'........... 27

Dwarf............ 28

Dwarf Ever-golden Oriental.

............ 19

Dwarf Golden Oriental. 18

EIIwanger's.......... 28

George Peabody's..... 26

Globe-shaped........ 28

GoIden Columnar Oriental....

Heath-leaved............. 28

Oriental.............. 17

Pyramidal................. 27

Rollinson's Golden..... 18

Rosenthal's......... 28

Siberian........... 27

Thread-branched...... 34

Tom Thumb......... 28

Vervæne's.......... 27

Aronia.

138

Arrow-wood . . . . . . . . 127

Ash, Flowering....... 84

Green............. 65

White............ 65

Azaleas, Deciduous...... 101

Flame..............102

Fragrant...............

Ghent...............101

Hardy Indian. . . . . . . 51

Hardy White........ 51

Japanese........ 50, 102

Southern...

102

White Summer........ 103

Yodogawa.............. 102

Bamboo, Dwarf.........146

Barberry, Box-leaved. ... 58 Common........... 136

HoIly-leaved........ 58

Japanese. . . . . . . . . 135

Purple-leaved.........136

Siebold's............. 135

Basswood............ 66

Bean, Indian......... 79

Beech, American....... 91

Copper............ 96

European........... 73

Fern-leaved.......... 73

Large-leaved Copper... 96

Purple............. 96

Rivers’ Blood-leaved... 96

Weeping............ 73

Birch, American White... 91

Black.

Canoe.
Birch, Cut-leaved Weeping White.

European White....... 72

Paper.............. 91

Purple-leaved White.... 95

Red............... 91

River............ 91

Sweet............ 90

Yellow............. 90

Beauty Fruit..........136

Bittersweet........... 148

Bladder-Nut........... 126

Japanese . . . . . . . . . 126

Blueberry, High-bush . . . . 128

Box, Blue Round-leaved... 31 Bush.............30, 31

Dwarf............. 32

GoIden Japanese........ 31

Golden-tipped........ 32

Japanese Bush........ 31

Rose Box............ 58

Myrtle-Ieaved Bush.... 32

Silver-tipped........ 32

Tree.............. 32

Willow-Ieaved Bush.... 31

Bridal Bower..........125

Bridal Wreath............ 124

Broom, Scotch........... 112

Buckthorn............ 138

Burning Bush ..........

Corkbarked . . . . . . . . 137

Butterfly Bush........... 129

Button Bush...........130

Buttonwood, American... 66

Camellia, FaIse........ 88

Catalpa, Umbrella....... 72

Western............ 79

Cedar, Columnar Tufted. 20

Gray.............. 19

Gray Sitka........... 25

Japanese.............. 19, 34

Japanese Temple...... 34

Lee's Golden.......... 20

Mt. Atlas Silver....... 14

Lebanon ............ 34

Pendulous Red........ 35

Plume-tipped Red.... 35

Red.............. 19

Spreading Virginia..... 39

Tall Columnar....... 20

Cedrela, Chinese....... 79

Cherry, Cornelian... . . . . . 111

Double Pink-flowering. 79

Double White-flowering 79

European Bird....... 79

Weeping Pink Japan... 79

Wild Black........... 79

Chestnut, Japanese..... . 72

Spanish.......... 72

Chokeberry, Bíack........ . 138

Red.....................

Cinquefoil, Shrubby . . . . . 132

Clematis, Heavy-scented. 149 Japanese. . . . . . . . 148 Large-flowered. . . . . . . . . 149 Scarlet................. 148

Small-flowered..... 148, 149

Sweet............... 148

Wild ............... . 149

Coffee Tree, Kentucky... . 84

Coral Berry............ 138
Crab, Bechtel's Double-

flowering.......... 88

Chinese Double-flower-

ing............ 88

Double-flowering..... 88

Dwarf .......... 88

Flowering. ....... 88

Parkman's.......... 88

Red-flowered........ 88

Siberian Flowering. . . . . 87

Sweet-scented........ 88

Cranberry, High-bush. . . . 127

Japanese Bush........ 127

Cucumber Tree......... 85

Currant, Golden........... 122

Indian.............. 138

Pink-flowered........122

Cypress, Club-moss...... 24

Compact.......... 24

Bald.............. 97

Thread-branched...... 22

Dwarf............ 24

Dwarf Garden.......... 24

Gamboge-yellow....... 23

Golden Dwarf Garden. . 25

Golden Pea-fruited..... 23

Golden-plumed........ 23

Golden Thread -

branched......... 22

Gray.................. 23

Green-plumed.......... 23

Heather-leaved....... 24

Pea-fruited.......... 22

Silver-plumed......... 23

SuIphur-colored Dwarf 24

Thuya-like.......... 24

Tree, of Japan......... 23

Deutzia, Carmine-flowered..............113

Compact..............114

Double Pink.......... 112

Double White...........112

Dwarf..............113

Lemoine's............... 113

Pride of Rochester... . . .112

Rose-flowered.........113

Rough-leaved..........114

Single White...........112

Small-flowered...........114

Waterer's..............113

Wells'.................113

Dockmackie.............126

Dogwo od, Alternateleaved............ 81

Weeping White....... 81

Japanese. . . . ....... 81

Panicled................... 811

Red-flowering....... 81

Silky ................ 111

White-flowering...... 81

Elderberry, Black........ 123

Cut-leaved European...123

Golden-leaved Euro-

pean.............123

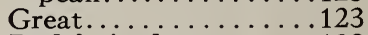

Red-fruited...............

EIder, Box...... . . . . . 89

EIm, American.......... 68

Broad-leaved English... 69

Columnar Wych....... 69

Cornish............. 69 
EIm, English.......... 69 Huntingdon............... 69 Purple-leaved Wych... 96 Scotch........... 69 Wych................6 69

Empress Tree.......... 87

Erianthus................

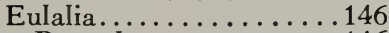

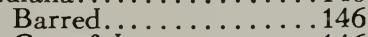

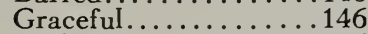
Variegated............ 146 Euonymus, Evergreen.... 58

Fir, Blue Douglas... . . . . 15 Douglas............. 11 Nordmann's......... 14 Silver Cork.......... 13 Spanish........... 15 White............. 11

Fern, Sweet............. 139

Fetterbush, Japanese..... 50 Mountain......... 50

Fringe, White..........110

Garland Flower....... 51

Ginkgo Flowe (Kèria), Double.........110 Single............... Variegated-leaved...... . . . . .

Goat-Wort.............. 132

Golden-BeII, Drooping.... 116 Fortune's............116 Green-twigged........ . 116 Variegated-leaved......116

Golden Chain......... 84 Drooping........... 84

Gold Flower.........132

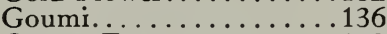

Grape, Fox..............

Frost. . . . . . . . 150

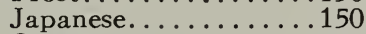

Oregon................. 52

Summer.................

Grass, Lyme............ 146

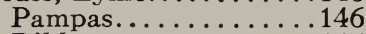
Ribbon................. 146

Gum, Sour........... 92 Sweet............... 66

Haw, Black.............. 128

Hawthorn, Double Pink. 83 Double Rose-flowered.. 83 Double White....... 83 English............ 83 Paul's Double Scarlet. . 83 Red-flowered........ 83

Hazel, American........... 136 Cut-leaved...............136

Purple-leaved..........136

Hemlock............ 11 Carolina........... 16 Japanese................. 16 Sargent's Weeping..... 37 Small-leaved......... 37

Hercules' Club........... 90

Hickory, Shagbark....... 72

Holly, American........ 57 Japanese.......... 56 English............ 57 Fortune's Japanese.... 57

Honeysuckle........... 149 Bush..................120 Chinese Fragrant Bush.119 FIy Bush...........120 Golden............... . . 149
Honeysuckle, Hall's. . . . . 149

Japanese. . . . . . . . . . 149

Japanese Bush.......... 119

Low-bush . . . . . . . 119, 139

Manchurian...........119

Tartarian Bush........ 120

Scarlet Trumpet........149

Shrubby .....................

Standish's...........119

Hornbeam, American.... . 93

European........... 93
Hop........... 92

Horse-chestnut, European 77 Double White-flowered. 78

Dwarf.............106

Red-flowered.......... 78

Hydrangea, Banks of

Snow............131

Lawn........................

Panicled..............131

Wood........................

Iron Tree, Persian. . . . . . 86

Ironwood............ 92

Ivy, Boston.............. 148

English........... 60

Japanese Evergreen.... . 59

Jasmine, Yellow..........117

Judas Tree............. 80

June Berry, Dwarf......... 109

Juniper, Canadian. . . . . . 38

Caucasian................ 21

Chinese. .......... 20

Douglas' Golden... . . . . 38

Dwarf Chinese........ 38

Dwarf Golden Japanese 39

Fortune's........... 21

GoIden Japanese........ 39

Greek............. 20

Irish.............. 21

Japanese Trailing...... 39

Low Japanese......... 39

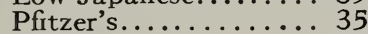

Purple............ 38

Silver-tipped........... 20

Swedish........... 21

Tall Japanese.......... 35

Upright........... 21

Upright Chinese........ 34

Kadsura Tree........... 93

Kerria, White.......... 122

Kudzu Vine.............150

Lace Shrub............ 125

Larch, European........ 97 Japanese........... 97

Laurel, Great.......... 47

Great Pink........... 47

Mountain......... 52

Leather Leaf........... 51

Lilac, Common............ 125

Common White.......125

Emodi's Himalayan..... 107

Himalayan................. 107

Hungarian................... 107

Japanese................ 107

Named Hybrids... . . . . . . 108

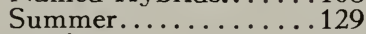

Persian.................. 107

Zabel's Hungarian. . . . . . 107

Lily-of-the-Valley Tree... 86

Lime Tree........... 67

Linden, American....... 66 European............. 67

Large-leaved............ 67
Page

Linden, Red-twigged. . 67

Silver-leaved........ 67

Locust, Black. . . . . . . . . . 88

Honey.......... 84

Water............... 84

Mahonia........... 52

Japanese............. 53

Maidenhair Tree....... 97

Magnolia, Evergreen..... 53

Great-Ieaved.........8 86

Japanese........... 85

Large White Chinese... 106

Lenne's .............105

Purple...........8.8. 106

Showy-flowered......106

Soulange's............. 105

Soulange's Purple........105

Starry.......................

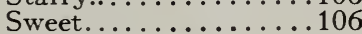

Matrimony Vine........ 139

Maple, Ash-leaved..... . . . 89

European Cork........ 93

European Sycamore... 84

Mountain.......... 90

Norway............. 64

Red.................6 65

Rock............. 65

Silver............6. 64

Striped........... 90

Sugar.............. 65

Sycamore..........64

Tartarian........... 93

White.............6 64

Wier's Cut-leaved Silver 71

Mist Tree............133

Purple.............134

Mock Orange............. 121

Golden-leaved.........121

Hybrid.............121

Monkey Tail........... 90

Mountain-Ash, American 75

European.......... 75

Oak-leaved......... 75

Weeping.......... 75

Mulberry, White....... 73

Russian Red........ 74

Russian White....... 74

Teas' Weeping........ 74

Myrtle.............. 59

Wax................139

Maple, Blood-leaved Japanese.............104

Cut-leaved $\dot{W}$ e eping Japanese........... 104

Golden Japanese.. . . . . . 104

Purple Sycamore. . . . . . 95

Reitenbach's Purple... 95

Schwedler's Purple..... 95

Weeping Cut-leaved Blood-leaved Japanese............... 104

Nettle Tree............ 91

Ninebark................... 125

Golden.....................

Oak, Black........... 68

Bur................ 74

English.............. 74

Golden........... 96

Mossy-Cup.... . . . . . 74

Pin...............6 68

Pyramidal English..... 75

Red..............6 68

Rock Chestnut. 
Oak, Scarlet $\quad . . . . . . . .69$ Swamp White.........6 67

Turkey............ 74

White............ 67

Oleaster, Japanese. . . . . . 136

Olive, Russian.........136

Orange, Hardy. . . . . . . . 110

Osier, American Red.. . . . 112

European Red........111

Golden-barked. . . . . . . . 112

Siberian Red.........111

Peach, Double Red...... . 86

Double White . . . . . . 86

Pearl Bush...........116

Pea, Siberian... . . . . . . 110

Pea Tree, Siberian. . . . . . 93

Pepperbush, Sweet... . . . 130

Periwinkle........... . 59

Persimmon, Common... . 73

Pine, Austrian......... . 10

Bhotan............. 15

BuII............. 10

Corean ............... 15

Dwarf Mountain......

osho)........... 21

Mountain.......... 40

Pitch........... 10

Red............. 10

Scotch.......... 10

Swiss Stone......... 15

Umbrella........... 25

White............. 10

Pinxter Flower. . . . . . . . 103

Pipe Vine.............148

Plane, Oriental.........66 66

Plum, Flowering. . . . . . . . 87

Purple-leaved......... 96

Poplar, Bolle's Silver.... 92

Carolina........... 92

Lombardy.......... 92

Prim................. 119

Privet, Amoor River. . . . . 117

California..........118

Bright-fruited.......... . . . . .

Chinese... . . . . . . . 119

European...........119

Golden...............118

Ibotan. . . . . . . . . . . . . . . . .

Regel's.............. 118

Quince, Japanese . . . . . . .110

Berry, Chinese...... 58

Himalayan......... 58

Wheeler's........... 58

Raisin, Wild.

Raspberry, Large-flowered Pink..........134

Red-Bud.

Japanese.

Reed, Giant.

Rhododendrons.

Catawban...........4 47

Dwarf............ 48

Rhodora........... 102

Roses, Alpine..

Briar.

141,142

Climbing

Dickson's Single $\mathrm{Hy}-$ bri

Dog

Everblooming . . . . 143, 144

Guelder.

Hybrid Perpetual...... 144
Meadow...................... 122

Memorial............133

Penzance Briars . . . . . . 142

Prairie.............133

Red-leaved. . . . . . . . . 122

Rugosa............142

Scotch..............122

Shining-leaved........133

Swamp...........133

Trailing............

White Wild. . . . . . . . . . 133

Wild............... 133

Rose of Sharon. . . . . . 130, 131

Tree-shaped.........131

Sassafras............ 92

Savin, Ground. . . . . . . . 39

Tamarisk-leaved... . . 78,39

Service, Berry......78, 109

Sheepberry................ 127

Shrub, Arbutus-flowered. 49

Silk Vine............150

Smoke Tree.............133

Snowball..............128

Japanese. . . . . . . . . . . 128

Single-flowered. . . . . . . 128

Sweet-scented.........126

Snowberry............. 138

Snow Garland......... . 124

Sophora, Weeping. . . . . . 76

Spice Bush............135

Spindle, Tree.......... . 129

Spirea, Blue .............. 129

Everblooming.........134

Everblooming Crimson 134

Fortune's............134

Lindley's............. 124

Reeves'.............. 124

Spruce, Alcock's . . . . . . . 14

Colorado.............. 11

Colorado Blue........ 15

Dwarf............ 21

Golden Norway . . . . . . 14

Gregory's............ 35

Ground ............ 21

Koster's Blue......... 15

Norway............11

Oriental........... 14

Pyramidal Norway.... 21

Tiger's Tail........... 14

Weeping Colorado Blue 35

Weeping Norway.... . . 35

White............ 11

Spurge, Japanese... . . . . . 60

St. John's Wort. . . . . . . . 132

Shrubby............. 132

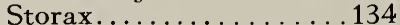

Sumac, Cut-leaved.... . . . 94

Cut-leaved Chinese.... 94

Cut-leaved Staghorn... 94

Shining............. 138

Fragrant. ............138

Osbeck's Chinese. . . . . . 94

Smooth............ 94

Staghorn.......... 94

Sweet Shrub............... 110

Japanese. . . . . . . . 110

Tamarisk, African...........

French............126

Tea, Hybrid Jersey........ . 130

Jersey..... . . . . . . . . 130

Thorn, Box........... . . . . . .
Page

horn, Carriere's....... 82

Cockspur.......... 82

Evergreen............ 57

Himalayan Silver...... . 136

Leland's Evergreen..... 57

Scarlet............88 82

Washington........... 83

Tree of Heaven. . . . . . . 65

Trumpet Vine......... 148

Scarlet........... 148

Tulip Tree.......... 85

Tupelo............... 92

Umbrella Tree. . . . . . . . 86

Varnish Tree........... 84

Viburnum, Siebold's... . . . 128

Silky ............. 127

Virginia Creeper......... 148

Walnut, American Black. 73

Persian............. 73

English.......... 73

Japanese............ 73

Wayfaring Tree......... 127

Weigela, Carmine........ 115

Crimson........... 114

Hybrid................ 115

Pink..................114

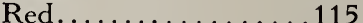

Rose............... . . . . .

Snow-White.........114

Variegated............ 114

White................. 114

Willow, Golden. . . . . . . . . 76

LaureI-leaved... . . . . . 94

Pussy..... . . . . . . . . . 94

Rosemary......... 75

Salmon-barked........... 76

Thurlow's Weeping.... 75

Virginia............... 117

Weeping........... 75

Weeping Golden...... 76

White............. 92

Winterberry, American. . . 137

Japanese. . . . . . . . . 137

Wistaria, Blue Chinese . . . 150

American........... 150

Large-flowered. ........ 150

White Chinese....... . 150

Witch-hazel. . . . . . . . . . . 137

Japanese. . . . . . . . . 117

Withe-Rod . . . . . . . . . . . 126

Woodbine, Engelmann's...148

Yellow Root. . . . . . . . . . 139

Yellow-wood........... 80

Yew, Canadian... . . . . . . 40

Clustered Japanese.... 36

Dovaston's......... 36

Dovaston's Golden..... 36

English............. 35

Dwarf English........ . 40

Elegant English....... 36

Erect English . . . . . . . . 36

Erect Golden English.... 36

GoIden Canadian...... 40

Golden Irish . . . . . . . . . 25

Irish .............. 25

Japanese........................ 37

Oriental.............. 35

Ram's-Horn......... 36

Short-leaved Japanese. 40

Spreading English..... 40

Washington's Go I d e n English...

Yulan Tree.............. 36 


\section{Index to Botanical Names}

Abelia rupestris (chinensis)...

Abies arizonica . . . . . . concolor............. 13 nordmanniana.......... 14

Acanthopanax spinosus

(Aralia pentaphylla).109

Acer campestre........ 93

dasycarpum...........64 dasycarpum, var. Wieri

Iaciniatum . . . . . . 71

negundo............ 89

palmatum, var. aureum 104 palmatum, var. filici-

folium............ 104

pennsylvanicum..... . 89

platanoides.........64

platanoides, var.

Schwedleri......... 95

platanoides, var. Rei-

tenbachii.......... 95

pseudoplatanus......64, 84

pseudoplatanus, var.

purpureum.......995

polymorphum........ 104

polymorphum, $\mathrm{v}$ a $\mathrm{r}$.

atropurpureum......104

polymorphum, var. atropurpureum dissectum.......... 104

polymorphum, $\mathrm{v}$ a $\mathrm{r}$. atropurpureum $\mathrm{n}$ i grum............ 104

polymorphum, var. dissectum...........104

rubrum...........6 65

saccharinum.......6 65

spicatum......... 90

tataricum, var. ginnala. 93

Actinidia polygama......147

Asculus hippocastanum... 77 hippocastanum, var. flore-pleno........ 78

hippocastanum, var. rubicunda.......78

parviflora (Pavia macrostachya).........106

Ailanthus glandulosa..... 65

Akebia quinata......... 147

Alnus glutinosa......... 90 imperialis asplenifolia. 71 incana...........990 incana, var. laciniata.. 71

Amelanchier botryapium.109 canadensis.........78 vulgaris... . . . . . . . . . 109

Ampelopsis quinquefolia. . 148 quinquefolia, var. Engelmanni..........148 tricuspidata; syn. Veitchii.......... 148

Andromeda arborea. . . . . 86 (Pieris) floribunda.... 50 (Pieris) japonica...... 50

Aralia japonica.......... 90 spinosa............... 90 pentaphylla.............. 109

Aristolochia sipho......... 148

Arundo donax........... 146

Azalea amœena......... 50 amœna, var. Hino-di-giri 50
Azalea arborescens ..... $\begin{array}{r}\text { Page } \\ 103\end{array}$

calendulacea................. 102

canadensis................

Fuji-manyo........... 102

indica, var. album...... 51

ledifolia, var. Ieucan-

thum........... 51

ledifolia, var. Ieucanthum roseum....... 51 ledifolia, var. narcissi-

flora............ 102

mollis..................

nudiflora............ 103

pontica.....................

vaseyi..............102

viscosa............... 103

Bambusa metake........146

Benzoin odoriferum......135

Berberis dulcis......... 58

ilicifolia. . . . . . . . . 58

sieboldii. .......... 135

thunbergii..........135

vulgaris............. . 136

vulgaris, var. purpurea.136

Betula alba......... 72 alba, var. Iaciniata pendula...........72

alba, var. purpurea.... 95

Ienta..............99 90

Iutea............. 90

nigra (rubra)........ 91

papyrifera.......... 91

populifolia............. 91

Bignonia grandiflora.... . 148

radicans............ 148

Biota orientalis......... 17 orientalis, var. aurea conspicua......... 18

orientalis, var. aurea nana........... 18

orientalis, var. compacta............ 19

orientalis, var. elegantissima........... 18 orientalis, var. filiformis 34 orientalis, var. semperaurescens.......... 19

Buddleia veitchiana...... 129 Buxus japonica, var. aurea............. 31 japonica, var. Fortunei. folia............. folia............... var. folia glauca ....... sempervirens .........30, 31 sempervirens, var. angustifolia variegata... 32 sempervirens, var. arborescens......... 32 sempervirens, var. argentea marginata.... 32 sempervirens varieties.. 31 sempervirens, var. myrtifolia

sempervirens, var. salicifolia........... 31

sempervirens, var. suffruticosa....... 32

Callicarpa purpurea........ 136

Calycanthus floridus..... 110
Page

Calycanthus præcox. . . . 110

Caragana arborescens.93, 110

Carya alba.......... 72

Caryopteris mastacanthus 129

Carpinus americana (caroliniana).........993

betulus................ 93

Cassandra........... 51

Castanea crenata (japonica).......... 72

sativa (vesca).......... 72

Catalpa bignonioides.... . 79

nana (bungei)........ 72

speciosa............ 79

Ceanothus americanus....130 americanus, var. Gloire Plantieres.............. 130

Cedrela sinensis........ 79

Cedrus atlantica, var. glauca.......... 14

Iibani................. 34

Celastrus scandens... . . . . 148

Celtis occidentalis... . . . . 91

Cephalanthus occiden talis...............130

Cerasus avium, var. alboplena........... 79

avium, var. roseo-pendula............. 79 avium, var. roseo-plena. 19 padus............ 79 serotina.......... 79 sieboldii........... 79

Cercidiphyllum japonicum 93

Cercis canadensis....... 80 japonica................. 107

Chamæcyparis nutkaensis 25

Chamædaphne (Cassandra) calyculata..... 51

Chionanthus virginica.... 110

Citrus trifoliata........110

Cladrastis tinctoria..... . 80

Clematis coccinea......... 148

flammula.................. 148 graveolens...........149

paniculata............. . . 148

virginiana........... 149

Clethra alnifolia.........130

Comptonia asplenifolia...139

Corchorus japonicus.....110 japonicus, var. florepleno............110

japonicus, var. variegata...........110

Cornus alba............... 111 alternifolia........... 81 florida............. 81 florida, var. rubra. .... 81 florida, var. pendula.... 81 kousa............ 81 mas..............111 paniculata (candidissima)............111 sanguinea.............111 sericea....................... stolonifera..........112 stolonifera, var. aurea.. 112

Corylus americana.......136 avellana, var. Iaciniata.136 maxima, var. purpurea.136 Cotoneaster horizontalis. . 58 
Cotoneaster microphylla . 58 simonsiï.......... 58 wheeleri.

Cratægus carrierei. . 82

coccinea......... 82 cordata.......... 83 crus-galli.......... 82 oxyacantha........88 83 oxyacantha, var. alba

flore-pleno.........8 83 oxyacantha, var. coccinea flore-pleno.....8 83 oxyacantha, var. punicea.

oxyacantha, var. punicea flore-pleno...... 83 oxyacantha, var. rosea flore-pleno.........8 83 pyracantha (coccinea).. 57 pyracantha, var. Lelandii............ 5

Cryptomeria japonica.... 34 japonica, var. dracrydioides.......... 34 japonica, var. Lobbii... 19

Cydonia japonica.......110

Cytisus Iaburnum...... . 84 scoparius.........112

Daphne cneorum....... 51

Deutzia crenata........112 crenata, var. candidissima............112 crenata, var. Pride of Rochester........112 crenata,var. rosea-plena 112 crenata, var. Watereri..113 crenata, var. Wellsii.... 113 gracilis...........113 gracilis, var. carminea..113 gracilis, var. rosea..... 113 lemoinei.............113 Iemoinei, var. compacta 114 parviflora............114

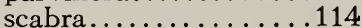

Diervilla floribunda, var. Lavallei ...........114 florida (rosea)....... . 114 florida, var. amabilis . . 114 florida, var. candida....114 florida nana, var. aurea variegata.........114 japonica, var. Eva Rathke...........115 japonica, var. Gronewegenii...........115 japonica, var. Mad. Coutourier........115 japonica, var. nivea....114 japonica, var. rubra....115 japonica, var. Steltzneri115 japonica, var. Van Houttei..........115 japonica, var. Verschaffeltii. ............115 sessilifolia ................ trifida...................

Diospyros virginiana..... 73

Elæagnus angustifolia....136 Iongipes (edulis) .......136

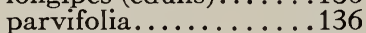

Elymus glaucus..........146 Erianthus ravennæ.......146 Eulalia japonica..........146
Eulalia japonica, var. gracillima univittata...146 japonica, var. variegata146 japonica, var. zebrina...146

Euonymus alata........137 atropurpurea........137 europæa............137 japonica and varieties. 58 radicans........... 59 radicans, var. Carrierei. 60 radicans, var. variegata 60 radicans, var. vegeta... 60 Exochorda grandiflora....116

Fagus ferruginea....... 91 sylvatica........... 73 sylvatica, var. asplenifolia............73 sylvatica, var. pendula. 73 sylvatica, var. purpurea 96 sylvatica, var. purpurea major............ 96 sylvatica, var. Riversii. 96 Forsythia fortunei......116 fortunei, var. aurea variegata.............116 intermedia..........116 suspensa.............116 viridissima...........116

Fraxinus americana...... 65 Ianceolata (viridis).....66 65 ornus............ 84 Ginkgo biloba (Salisburia adiantifolia) ....... 97

Gleditschia aquatica..... 84 triacanthos ......... 84

Gymnocladus canadensis. 84 Gynerium argenteum. . . .146

Hamamelis japonica.....117 virginiana..........137

Hedera helix.......... 60

Hibiscus, Ardens..........131 atropurpureus plenus...130 Boule de Feu......130, 131 Jeanne d'Arc. . . . . 130, 131 Lady Stanley..........130 purpureus foliis argen-

teus marginatus 130,131 syriacus........130, 131 totus albus......130, 131

violaceus...........130

Hicoria ovata (Carya alba)........... 72

Hop Tree............. 93

Hydrangea arborescens...131 arborescens, var. grandiflora........131

paniculata...........131 paniculata grandiflora...131

Hypericum aureum......132 hircinum...........132 moserianum.........132 prolificum............ 132

Ilex aquifolium........ 57 crenata.......... 56 crenata, var. buxifolia.. 56 crenata, var. Fortunei.. 57 crenata, var. Iatifolia... 56 crenata, var. microphylla.......... 57 opaca............. 57 sieboldii................. verticillata...........137 Itea virginica... . . . . . . 117
Jasminum nudiflorum. $\begin{array}{r}\text { Page } \\ 117\end{array}$

Juglans nigra........ 73 regia.............. 73 sieboldiana.......... 73

Juniperus canadensis. . . . . 38 canadensis, var aurea; syn. Douglasii...... 38 canadensis, var. plumosa............ 38

chinensis........... 20 chinensis, var. albovariegata........ 20 chinensis, var. femina (Reevesii) ......... 34 chinensis, var. Pfitzeriana............ 35 chinensis, var. virginalis 38 communis......... 21 communis, var. hibernica............. 21 communis, var. oblonga 21 excelsa, var. stricta.... 20 japonica............ 39 japonica, var. aurea.... 39 japonica, var. nana aurea........... 39 recurva, var. squamata. 39 rigida............. 35 sabina................ 39 sabina, var. tamarisci-

folia............ 39 sphærica (fortunei)..... 21 virginiana.......... 19 virginiana, var. Cannartii........... 20 virginiana, var. elegantissima........ 20 virginiana, var. glauca.. 19 virginiana, var. Kosteri. 39 virginiana, var. pendula 35 virginiana, var. plumosa............ 35

virginiana, var. Schottii............ 20

Kalmia Iatifolia.......... 52 Koİreuteria paniculata... 84 Laburnum vulgare (Cytisus Iaburnum).... . 84 vulgare pendulum..... 84

Larix decidua (europæa).. 97 Ieptolepis (kaempferi) . . 97

Ligustrum amurense.... 117 ciliatum.............117 ibota.................117 ibota, var. Regelianum. 118 medium.............118 ovalifolium..........118 ovalifolium, var. aureum..............118 sinense.................. vulgare................... 119

Liquidambar styraciflua. . 66 Liriodendron tulipifera... 85

Lonicera fragrantissima. . 119 heckrottii.............119 japonica, var. Halleana.150 morrowii. ...........119 ruprechtiana ........... 119 sempervirens, var. fuchsioides ...........150 standishii.............119 tatarica.................. tatarica (rubra)........ 120 
Lonicera tatarica, var. alba ...........120 tatarica, var. bella albida.............120 tatarica, var. chrysantha.............120 tatarica, var. gracilis. . 120 tatarica, var. splendens. 120 xylosteum.......... 120

Lycium chinense............ 139

Magnolia acuminata.... 85 alba superba........106 conspicua (yulan)...... 85 glauca................. 106 grandiflora......... 53 hypoleuca......... 85 kobus.............. 85 macrophylla....... 86 obovata............... soulangeana.........105 soulangeana, var. Lennei.............105 soulangeana, var. nigra.105 speciosa............106 stellata (halleana).....106 tripetala............86

Mahonia aquifolium..... 52 japonica........... 53

Morus alba............ 73 alba, var. tatarica..... 74 alba, var. tatarica pendula............74 alba, var. tatarica rubra 74

Myrica cerifera.........139

Nyssa sylvatica.......... 92

Ostrya virginica........ 92

Oxydendrum arboreum (Andromeda arborea) 86

Pachysandra terminalis.. 60

Parrotia persica........ 86

Paulownia imperialis.... 87

Periploca græca... . . . . . 150

Persica vulgaris, var. alboplena............ 86 vulgaris, var. sanguinea plena...........86

Phalaris arundinacea, var. variegata..........146

Philadelphus coronarius . . 121 coronarius, var. aureus. 121 grandiflorus ........121 lemoinei............... lemoinei, var. erectus...121 Ie moinei, var. Mt. Blanc.............121 zeyheri, var. speciosissimus...........121

Picea alba.......... 11 alcockiana........... 14 excelsa............ 11 excelsa, var. aurea ..... 14 excelsa, var. Gregoryana............ 35 excelsa, var. inverta.... 35 excelsa, var. Maxwellii. 21 excelsa, var. pumila... 21 excelsa, var. pyramidalis.............. 21 orientalis............ 14 pinsapo........... 15 polita.............. 14 pungens........... 11 pungens, var. pendula. 35
Page
Picea pungens, var. glauca 15 pungens, var. Kosteriana............. 15

Pieris............ 50

Pinus austriaca........ 10 cembra........... 15 densiflora, var. globosa. 21 excelsa........... 15 koraiensis.......... 15 montana.........440 mughus..........44 ponderosa......... 10 resinosa .......... 10 rigida........... 10 strobus........... 10 sylvestris.......... 10 Pyrus (Aronia) arbutifolia, var. brilliantissima................ 138 baccata......... 87 coronaria......... 88 floribunda.

floribunda, var. atrosanguinea.

floribunda, var nigra 138 floribunda, var. Scheideckeri...

halliana (parkmanii).... 88 ioensis, var. Bechtelii... 88 spectabilis......... 88 toringo........... 88

Podocarpus koraiana.... 35 Populus alba, var. Bolleana............ 92 monilifera (carolinensis) 92 nigra, var. fastigiata.... 92

Potentilla fruticosa... . . . 132

Prunus pissardii........ 96 triloba............ 87

Pseudotsuga douglasii..... 11 douglasii, var. elegans glauca........... 15

Ptelea trifoliata......... 93

Pueraria thunbergiana....150

Quercus alba...........67 67 bicolor (platanoides)... 67 cerris........... 74 coccinea.........66 68 macrocarpa........ 74 palustris........... 68 pedunculata (robur).... 74 pedunculata, var. concordia............ 96 pedunculata, var. fastigiata............ 75 prinus.............. 92 rubra............6 68 velutina.......... 68

Retinospora ericoides..... 24 frlifera........... 22 filifera, var. aurea..... 22 leptoclada.......... 24 lycopodioides........ 24 obtusa............ 23 obtusa, var. compacta... 24 obtusa, var. Crippsii.... 23 obtusa, var. nana..... 24 obtusa, var. nana aurea. 25 pisifera............. 22 pisifera, var. aurea.... 23 plumosa........... 23 plumosa, var. argentea. 23 plumosa, var. aurea.... 23
Retinospora plumosa, var. flavescens......... 24 plumosa, var. sulphurea 24 squarrosa........... 23

Rhamnus cathartica... . . 138 Rhododendron, Abraham Lincoln........... 45

album.............. 45

album elegans........ 44

album grandiflorum... . 44

Alex. Dance......... 45

Amphion........... . 44

Anna Parsons........ . 46

atrosanguineum......45

Blandyanum..........4 45

Boule de Neige... . . . . . 44

candidissimum........ 44

Caractacus . ......... 46

catawbiense ......46,47

catawbiense, var. alba.. 44

Charles Bagley....... . 46

Charles Dickens........ . 45

C. S. Sargent......... . 45

Daisy Rand.......... 45

delicatissimum ..... 44

Edward S. Rand...... 45

everestianum......... 46

F. D. Godman........ 45

General Grant......... 45

giganteum......... 45

hammondii............ 48

Hannah Felix........ 46

Henry Probasco....... . 46

Herbert Parsons...... . 46

H. H. Hunnewell. . . . . 45

hirsutum........... 48

H. W. Sargent........ 45

Ignatius Sargent. . . . . . . 44

imbricatum ........ 48

J. Marshall Brooks.... . 45

John Spencer.......... 46

J. R. Trumpy....... . 45

Kettledrum........4 46

Kissena........... 46

Lady Armstrons... . . . . . 46

Lady Clermont... . . . . . 45

Lady Gray Egerton.... . 44

Lee's ........... 46

Iuciferum......... 44

Mad. Carvalho....... 44

Mad. Masson......... 44

maximum......... 47

maximum, var. roseum. 47

Mrs. H. IngersolI. . . . . 46

Mrs. John Clutton. ... . . 44

Mrs. Milner........ 45

multiflorum......... 48

myrtifolium........ 48

odoratum.......... 48

OId Port. ........... 46

Parson's gloriosum.... 44

Parson's grandiflorum rubrum.......... 44

President LincoIn...... 45

punctatum..........48

purpureum crispum .... 46

purpureum elegans..... 46 purpureum grandiflo-

rum 46

roseum elegans......44,46 roseum Iuteum. . . . . . . . 44 roseum superbum..... 46

Sefton............ 46 

Rhododendron wilsonia-
num.............. 48

Rhodotypos kerrioides.... 122

Rhus aromatica....... 138 copallina........... 138 cotinus...........133 cotinus, var. atropurpurea...........134 glabra............ 94 glabra, var. laciniata... 94 typhina.......... 94 typhina, var. Iaciniata.. 94 osbeckii............ 94 osbeckii, var. Iaciniata.. 94

Ribes aureum..........122 gordonianum ....... 122

Robinia hispida... . . . . . 134 pseudacacia......... 88

Rosa blanda..........122 canina............132

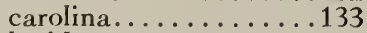
Iucida............... 133 lucida, var. alba........133 multiflora............122 nitida..............133 rubiginosa........... 142 rubiginosa hybrids..... 142 rubrifolia...........122 rugosa................. rugosa hybrids. . . . . . 142 setigera.................. 133 spinosissima.....122, 142 wichuraiana ..........133 wichuraiana hybrids. . 145

Rubus odoratus........134

Salisburia adiantifolia....997

Salix alba............ 92 caprea........... 94 babylonica......... 75 elegantissima............ 75 incana............ 75 Iutea............ 76 lutea, var. pendula.... 76 pentandra.......... 94 vitellina, var. britzensis 76

Sambucus canadensis.....123 melanocarpa.........123 nigra, var. aurea..... 123 nigra, var. Iaciniata. . . . 123 pubens (racemosa).....123

Sassafras officinale...... 92

Sciadopitys verticillata... 25

Sophora japonica, var. pendula...........

Sorbus americana......... 75 aucuparia...........75 aucuparia, var. pendula 75 aucuparia, var. querci-

folia............ 75 billardii............. 134 bumalda................. bumalda, var. Anthony Waterer.............. 134 callosa...............134 callosa, var. al $\ldots \ldots \ldots . . . .134$ callosa margaritæ....... 134
Spiræa lindleyana ...... $\begin{array}{r}\text { Page } \\ 124\end{array}$ opulifolia............ 125 opulifolia, var. aurea... 125 prunifolia flore-pleno....124 reevesiana..........124 salicifolia........... sorbifolia................. thunbergii..........124 vanhouttei...............

Staphylea bumalda . . . . . 126 colchica............126 Stephanandra flexuosa.....125 Stuartia pseudo-camellia. 88 Styrax japonica.........134 Symphoricarpos racemosus . . . . . . . 138 vulgaris............ 138

Syringa japonica......... 107 josikæa................. 107 josikæa, var. H. Zabel. . 107 persica, var. alba... . . . 107 villosa..............107 villosa, var. Emodi 107, 125 vulgaris............108 vulgaris alba.........125

Tamarix africana (parvi-

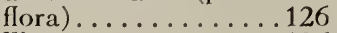
gallica...............126 Taxodium distichum.... 97

Taxus baccata......... 35 baccata, var. adpressa... 40 baccata, var. Dovastonii..............36 baccata, var. Dovastonii aurea........ 36 baccata, var. elegantissima........... 36 baccata, var. erecta.... 36 baccata, var. erecta aurea. .

baccata, var. fastigiata. 25 baccata, var. fastigiata aurea............25

baccata, var. gracilis pendula.......... 36 baccata, var. repandens 40 baccata, var. Washingtonii aurea......... 36 canadensis........... 40 canadensis, var. aurea.. 40 cuspidata.......... 37 cuspidata, var.brevifolia 40 cuspidata, var. capitata 36

Thuya occidentalis...... 26 occidentalis, var. aurea. 26 occidentalis, var. DougIasii............ 27 occidentalis, var. ĖIwangeriana........ 28 occidentalis, var. ericoides........... 28 occidentalis, var. globosa............ 28 occidentalis, var. plicata pyramidalis..... 27 occidentalis, var. pyramidalis ....... 27
Thuya occidentalis, var Page recurva nana ....... 28 occidentalis, var. Rosenthalii........... 28 occidentalis, var. spiralis.............. 27 occidentalis, var. Tom Thumb.......... 28 occidentalis, var. Vervæneana......... 27 occidentalis, var. Wareana..

occidentalis, var. Wareana aurea........ 27

Thuyopsis borealis, var. latifolia glauca...... 25

Tilia americana......... 66 platyphyIlos........67 67 tomentosa (argentea).... 67 vulgaris (europæa)..... 67 vulgaris, var. rubra.... 67

Tsuga canadensis....... 11 canadensis, var. gracilis 37 canadensis, var. Sargentii pendula...... 37 caroliniana........... 16 sieboldii............ 16

UImus americana......... 68 campestris.......... 69 campestris, var. Iatifolia (major)....... 69 campestris, var. WheatIeyi...........66 scabra, var. Dampieri; syn. fastigiata..... 69 scabra, var. Huntingdonii............ 69 scabra, var. montana... 69 scabra, var. purpurea... 96

Vaccinium corymbosum. . 128

Viburnum acrifolium.... . 126

carlesii............126 cassinoides..............

dentatum........... 127

dilatatum........................

Iantana................ 127

lentago............... 127

molle.......................

nitidum. . . . . . . . 127

opulus. . . . . . . . . 127

opulus, var sterile.....128

prunifolium......... 128

sieboldii . . . . . . . . 128

tomentosum, var. plicatum............ 128

tomentosum.......128

Vinca minor.............. 59

Vitis æstivalis ........... 150

heterophylla......... 150

labrusca................. 150

vulpina................

Wista ria chinensis.........

chinensis alba........150

magnifica........... 150

multijuga............. 150

Xanthorrhiza apiifolia... 139

Yucca filamentosa....... 53 



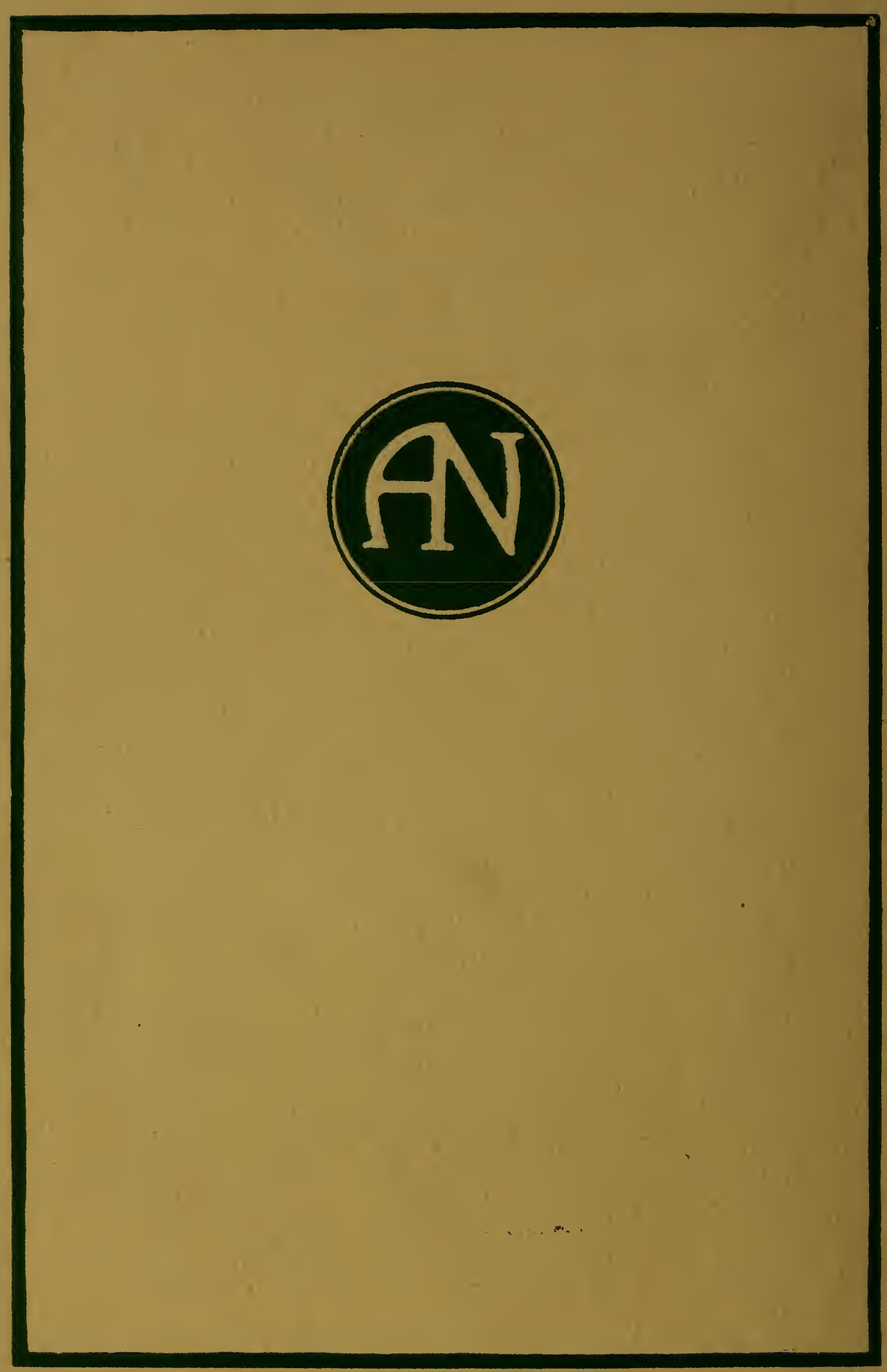

